\title{
A COMUNIDADE BACTERIANA ENDOFÍTICA E EPIFÍTICA DE SOJA (Glycine max) E ESTUDO DA INTERAÇÃO ENDÓFITOS-PLANTA
}

\author{
JÚLIA KUKLINSKY SOBRAL
}

Tese apresentada à Escola Superior de Agricultura "Luiz de Queiroz", Universidade de São Paulo, para obtenção do título de Doutor em Agronomia, Área de Concentração: Genética e Melhoramento de Plantas.

\author{
PIR A C I C A B A \\ Estado de São Paulo - Brasil \\ Dezembro - 2003
}




\title{
A COMUNIDADE BACTERIANA ENDOFÍTICA E EPIFÍTICA DE SOJA (Glycine max) E ESTUDO DA INTERAÇÃO ENDÓFITOS-PLANTA
}

\author{
JÚLIA KUKLINSKY SOBRAL
}

Bacharel em Ciências Biomédicas

Orientador: Prof. Dr. JOÃO LÚCIO DE AZEVEDO

Tese apresentada à Escola Superior de Agricultura "Luiz de Queiroz", Universidade de São Paulo, para obtenção do título de Doutor em Agronomia, Área de Concentração: Genética e Melhoramento de Plantas.

PIRACICABA

Estado de São Paulo - Brasil

Dezembro - 2003 
Dados Internacionais de Catalogação na Publicação (CIP) DIVISÃO DE BIBLIOTECA E DOCUMENTAÇÃO - ESALQ/USP

\author{
Sobral, Júlia Kuklinsky \\ A comunidade bacteriana endofítica e epifítica de soja (Glycine max) e estudo \\ da interação endófitos-planta / Júlia Kuklinsky Sobral. - - Piracicaba, 2003. \\ 174 p. : il. \\ Tese (doutorado) - Escola Superior de Agricultura Luiz de Queiroz, 2003. \\ Bibliografia. \\ 1. Bactéria endofítica 2. Crescimento vegetal 3. Diversidade genética 4. \\ Ecologia microbiana 5. Herbicida sintético 6. Relação planta-bactéria 7. Soja 8. \\ Variabilidade genética I. Título \\ CDD 633.34
}

\title{
"Permitida a cópia total ou parcial deste documento, desde que citada a fonte - $O$ autor"
}


Aos meus pais,

Elly C. Kuklinsky Sobral e Arnaldo Vieira Sobral,

pelo amor que nos une, constante carinho $e$ dedicação, por minha formação e, por estarem sempre ao meu lado.

A Alberto E. P. de Araújo, pelo carinho, paciência, dedicação e apoio durante todo o nosso convívio.

DEDICO

Ao meu Pai, Arnaldo V. Sobral,

meu eterno orientador, tanto em minha vida pessoal quanto profissional, por seu incondicional incentivo e estímulo para eu prossiga na carreira científica. 


\section{AGRADECIMENTOS}

- Ao Prof. Dr. João Lúcio de Azevedo pela orientação, apoio, estímulo e, principalmente, pelo privilégio de fazer parte de sua equipe de pesquisa.

> Ao Dr. Welington Luiz de Araújo pela importante co-orientação, gratificante amizade, paciência, dedicação e apoio incondicional durante todo o desenvolvimento desta tese.

$>$ À Profa. Dra. Aline A. Pizzirani-Kleiner pela amizade e oportunidade do desenvolvimento deste trabalho no Laboratório de Genética de Microrganismos - ESALQ/USP.

> Ao Prof. Dr. Isaias O. Geraldi pela cooperação, apoio e facilidades concedidas durante os experimentos de campo.

$>$ À Profa. Dra. Janete Magali de Araújo por ter sido a principal incentivadora da minha vinda para ESALQ - Piracicaba.

> Aos meus pais, Elly e Arnaldo, por todo amor e apoio, alicerces fundamentais para que eu pudesse desenvolver este trabalho.

$>$ A Alberto E. P. Araújo pelo carinho, incentivo e paciência durante os inumeráveis períodos em que estive "estressada".

> Às amigas Adalgisa R. Torres, Cristina S. Maki, Joelma Marcon, Tais G. Lana e, em especial, Mayra K. Martins e, aos amigos Ricardo Yara e Rudi E. Procópio pela amizade, apoio e incentivo.

> A Rodrigo Mendes pela amizade e colaboração em diversas etapas do desenvolvimento deste trabalho.

> Aos colegas do Laboratório de Genética de Microrganismos: Ágata C. H. Giancoli, Aline S. Romão, Andréa Guelfi, Carlos E. Ceroni, Claudia S. Gai, 
Carolina Almeida, Cristina Almeida, Fernando D. Andreote, Guilherme Tenório, José A. Silva, Léa C. Favaro, Luciana Cursino, Maria Beatriz Calderan, Maria Carolina Quecine, Maria Clara Pestana, Paulo T. Lacava, Priscilla B. Rossetto, e Uirá C. F. Belmonte, pelas construtivas "discussões de corredor" e agradável convivência.

> A Carlos E. Ceroni e José A. Silva pelo incentivo e apoio técnico durante o desenvolvimento deste trabalho.

> A Fernando Araújo e Cláudio Segatelli pelo apoio técnico durante os experimentos de campo.

> Aos funcionários do Departamento de Genética ESALQ/USP, em especial a Léia, Glória, Berdã e Vitor pelo apoio de ordem administrativa.

$>$ A todos os professores e colegas de curso do Departamento de Genética ESALQ/USP.

$>$ À CAPES pela bolsa de doutorado concedida e à FAPESP pelo apoio financeiro.

$>$ A todos que direta ou indiretamente contribuíram para a realização deste trabalho. 


\section{SUMÁRIO}

Página

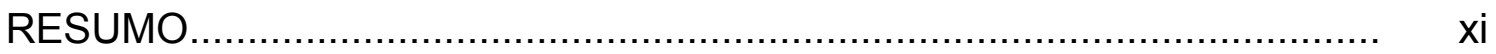

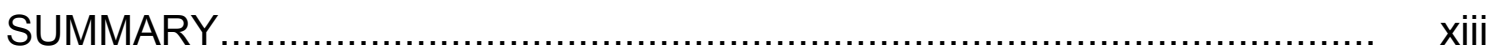

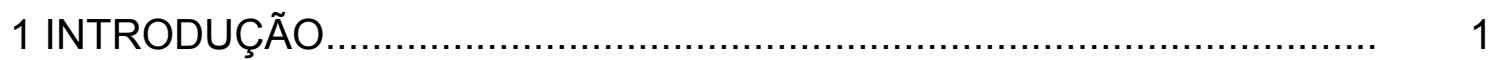

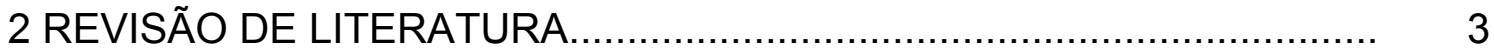

2.1 Bactérias associadas às plantas............................................ 3

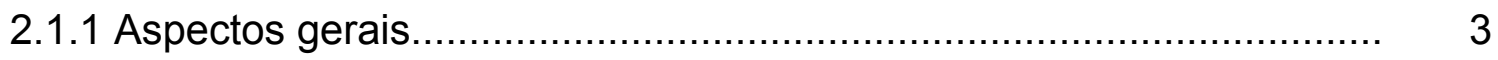

2.1.2 Importância do estudo das bactérias endofíticas........................... 5

2.1.3 Aplicações biotecnológicas de bactérias endofíticas........................ 6

2.2 Mecanismos de promoção de crescimento vegetal........................... 8

2.2.1 Produção de reguladores de crescimento vegetal.......................... 9

2.2.2 Solubilização de fosfato inorgânico......................................... 12

2.2.3 Fixação biológica de nitrogênio atmosférico................................ 14

2.3 Diversidade genética microbiana........................................... 16

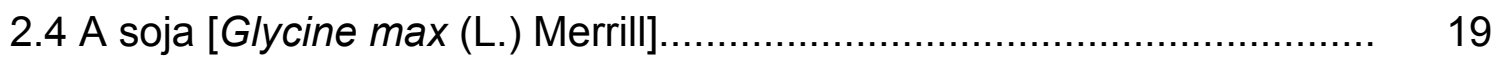

2.4.1 Importância econômica.................................................... 19

2.4.2 Bactérias endofíticas de soja............................................ 22

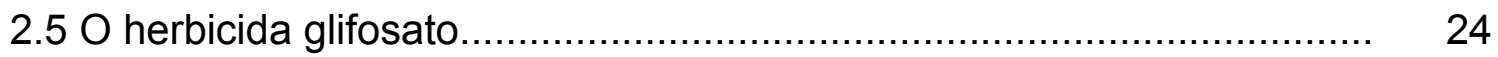

3 BACTÉRIAS ASSOCIADAS À SOJA: ISOLAMENTO,

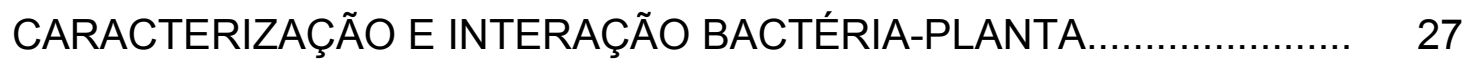

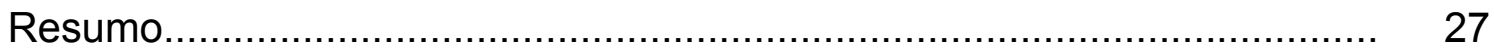




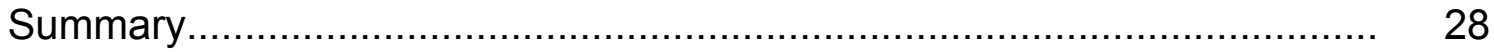

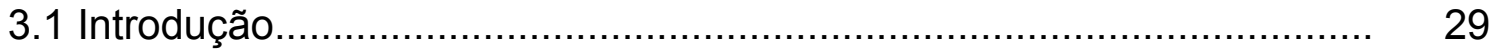

3.2 Material e Métodos........................................................................ 31

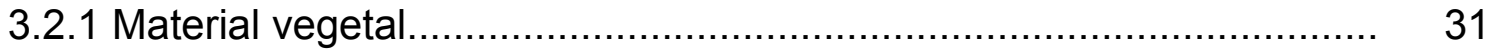

3.2.2 Processamento das amostras e isolamento de bactérias associadas à soja

3.2.3 Identificação dos isolados bacterianos............................................. 33

3.2.4 Extração de DNA genômico de bactérias.......................................... 33

3.2.5 Extração de DNA total de tecidos vegetais....................................... 34

3.2.6 Amplificação, restrição, sequenciamento e análise do 16S rDNA....... 34

3.2.7 PCR e análise por DGGE........................................................ 36

3.2.8 Análise estatística................................................................ 37

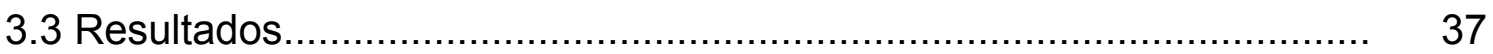

3.3.1 Avaliação da comunidade bacteriana cultivável endofítica e epifítica de soja.................................................................. 37

3.3.2 Isolamento, identificação e análise filogenética de bactérias endofíticas e epifíticas de soja................................................... 42

3.3.3 Análise de DGGE da comunidade bacteriana endofítica de soja........ 55

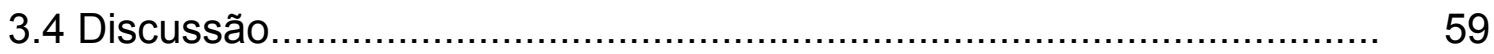

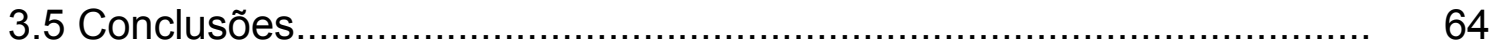

4 DIVERSIDADE GENÉTICA DE BACTÉRIAS ASSOCIADAS À SOJA E SEU POTENCIAL PARA PROMOÇÃO DE CRESCIMENTO

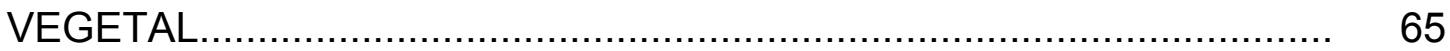

Resumo

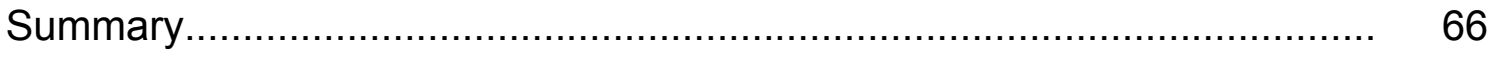

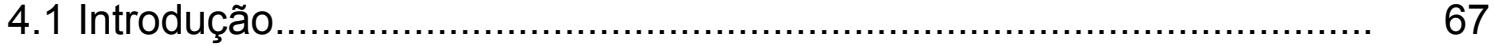

4.2 Material e Métodos.................................................................... 70

4.2.1 Isolados bacterianos e condições de cultivo...................................... 70 
4.2.2 Identificação de bactérias produtoras de ácido indol acético (AIA)..... 70

4.2.3 Identificação de bactérias solubilizadoras de fosfato inorgânico......... 71

4.2.4 Identificação de bactérias com capacidade de fixar $\mathrm{N}_{2} \ldots \ldots \ldots \ldots \ldots \ldots \ldots \ldots . . . . . . . .72$

4.2.4.1 Crescimento de bactérias em meio de cultura livre de nitrogênio.

4.2.4.2 Detecção do gene da nitrogenase (nifH) por meio de PCR ............. 72

4.2.5 Extração de DNA genômico de bactérias.......................................... 73

4.2.6 Amplificação e restrição do 16S rDNA (ARDRA).............................. 74

4.2.7 Avaliação de promoção de crescimento vegetal por bactérias

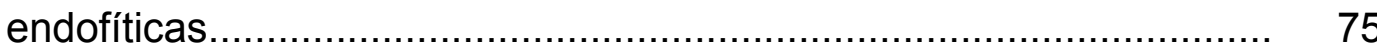

4.2.8 Análise estatística.................................................................. 75

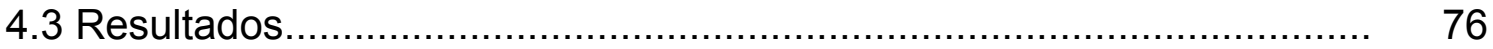

4.3.1 Seleção de bactérias endofíticas e epifíticas produtoras de auxina e solubilizadoras de fosfato inorgânico........................................... 76

4.3.2 Identificação de bactérias com potencial para fixar $\mathrm{N}_{2} \ldots \ldots \ldots \ldots \ldots \ldots \ldots . . . . . . . . . .79$

4.3.3 Análise da diversidade genética de bactérias endofíticas e

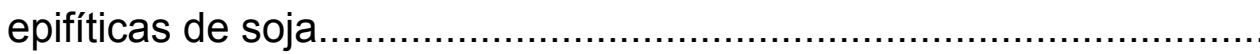

4.3.4 Avaliação de promoção de crescimento vegetal por bactérias endofíticas.

4.4 Discussão

4.5 Conclusões.

5 ISOLAMENTO E CARACTERIZAÇÃO DE BACTÉRIAS ENDOFÍTICAS

DE SOJA ASSOCIADAS À DEGRADAÇÃO DO HERBICIDA

GLIFOSATO

Resumo.

Summary. 101

5.1 Introdução. 
5.2.1 Material vegetal

5.2.2 Isolamento de bactérias endofíticas capazes de utilizar o glifosato como fonte de carbono.

5.2.3 Identificação dos isolados bacterianos. 105

5.2.4 Extração de DNA genômico de bactérias 106

5.2.5 Amplificação e restrição do 16S rDNA (ARDRA).... 106

5.2.6 Análise do polimorfismo gerado por marcadores de RAPD 107

5.2.7 Detecção do gene da nitrogenase (nifH) por meio de PCR. 108

5.2.8 Teste de sensibilidade ao herbicida glifosato. 109

5.3 Resultados 110

5.3.1 Avaliação e identificação da comunidade bacteriana endofítica de soja associada à degradação de glifosato.

5.3.2 Análise da variabilidade genética e detecção do gene nifH de bactérias endofíticas de soja associadas à degradação de glifosato

5.3.3 Sensibilidade ao herbicida glifosato por Burkholderia gladioli e Pseudomonas oryzihabitans

5.4 Discussão. 121

5.5 Conclusões.

6 ESTUDO DA INTERAÇÃO Methylobacterium spp. ENDOFÍTICAS E SOJA.

Resumo. 125

Summary. 126

6.1 Introdução 127

6.2 Material e Métodos 129

6.2.1 Material vegetal. 129

6.2.2 Isolamento de bactérias endofíticas de soja. 129

6.2.3 Reinoculação de bactérias endofíticas em sementes de soja. 130 
6.2.4 Preparação das amostras vegetais para MEV (Microscopia Eletrônica de Varredura) ............................................................ 131

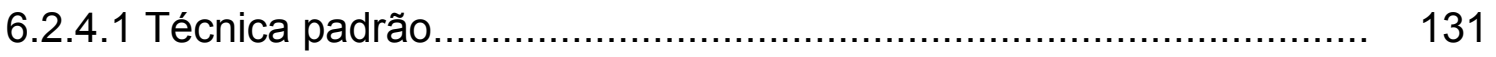

6.2.4.2 Protocolo para fraturar tecidos congelados em nitrogênio

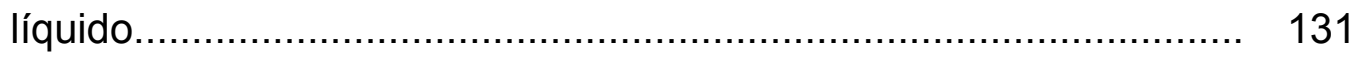

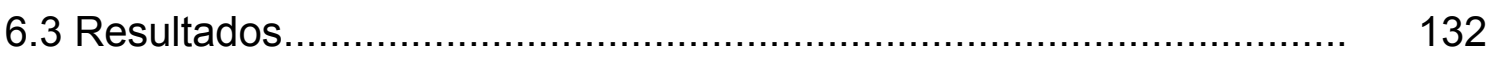

6.3.1 Avaliação da comunidade bacteriana endofítica de soja.................... 132

6.3.2 Avaliação da colonização de soja por Methylobacterium spp. ............ 135

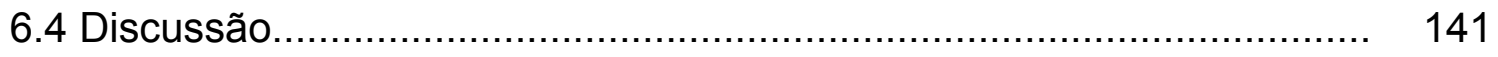

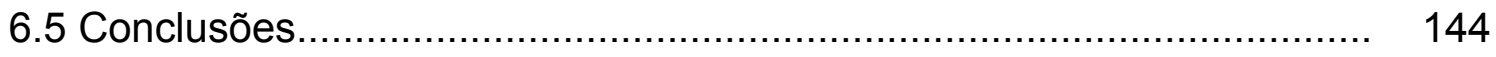

7 CONCLUSÕES GERAIS............................................................ 145

REFERÊNCIAS BIBLIOGRÁFICAS..................................................... 147 


\title{
A COMUNIDADE BACTERIANA ENDOFÍTICA E EPIFÍTICA DE SOJA (Glycine max) E ESTUDO DA INTERAÇÃO ENDÓFITOS-PLANTA
}

\author{
Autora: JÚLIA KUKLINSKY SOBRAL \\ Orientador: Prof. Dr. JOÃO LÚCIO DE AZEVEDO
}

\section{RESUMO}

Bactérias endofíticas e epifíticas podem conferir ao seu hospedeiro características como maior resistência a condições de estresse, alterações nas condições fisiológicas, fixação de nitrogênio atmosférico, suprimento de nutrientes, produção de reguladores de crescimento vegetal, entre outros. Desta forma, o presente trabalho teve por objetivos estudar a composição da comunidade bacteriana associada à soja e avaliar diferentes mecanismos de interação bactéria-planta hospedeira. Para isso, bactérias endofíticas e epifíticas de folhas, caules e raízes de duas cultivares de soja, crescidas em solo com e sem aplicação pré-plantio do herbicida glifosato, foram amostradas em três estádios de desenvolvimento do hospedeiro, durante as safras de $2000 / 01$ e 2001/02. Foram observadas diferenças significativas na diversidade e densidade bacterianas em relação às fases de crescimento da soja e tecidos da planta. Os principais grupos foram identificados como pertencentes aos gêneros Pseudomonas, Burkholderia, Ralstonia, Enterobacter, Pantoea, Acinetobacter, Agrobacterium e Methylobacterium. Além da avaliação de populações cultiváveis, análise por DGGE revelou que a comunidade bacteriana endofítica de raiz de soja pode ser influenciada pelo tratamento do 
solo com o herbicida glifosato. O potencial destas bactérias para a promoção de crescimento vegetal por bactérias associadas à soja foi avaliado, sendo possível observar que populações endofíticas e epifíticas de soja apresentam características relacionadas à promoção de crescimento vegetal e que fatores como cultivar e estádio fenológico do hospedeiro podem influenciar as freqüências destas populações. A análise da variabilidade genética destas populações bacterianas revelou que diferentes fatores ambientais também podem influenciar a diversidade de grupos bacterianos. Além disso, populações endofíticas com capacidade de crescer na presença do herbicida glifosato foram caracterizadas e identificadas como pertencentes às espécies Burkholderia gladioli e Pseudomonas oryzihabitans, enquanto que Methylobacterium spp. colonizam ativamente a superfície e os tecidos internos de soja após inoculação via semente. Os resultados obtidos podem oferecer uma contribuição para a melhor compreensão da interação microrganismossoja e, conseqüentemente, de sua aplicação na cultura deste vegetal. 


\title{
ENDOPHYTIC AND EPIPHYTIC BACTERIAL COMMUNITY FROM SOYBEAN (Glycine max) AND STUDY OF THE INTERACTION ENDOPHYTES-PLANT
}

\author{
Author: JÚLIA KUKLINSKY SOBRAL \\ Adviser: Prof. Dr. JOÃO LÚCIO DE AZEVEDO
}

\section{SUMMARY}

Endophytic and epiphytic bacteria may increase the fitness of the plant host by increasing resistance to stress conditions, alterations in the physiologic conditions, fixation of atmospheric nitrogen, nutrient supplying and plant growth regulators production. The aims of the present work were to study the composition of soybean-associated bacterial community and to evaluate different mechanisms for bacteria-host plant interaction. For that, endophytic and epiphytic bacteria from leaves, stems and roots of two soybean cultivars, planted in soil with and without pre-planting application of the glyphosate herbicide, they were colleted in three development stages of the host, during two crops. Significant differences were observed in the bacterial diversity and population density in relation to the soybean growth stages and plant tissues. The principal groups were identified as belonging to the genera Pseudomonas, Burkholderia, Ralstonia, Enterobacter, Pantoea, Acinetobacter, Agrobacterium and Methylobacterium. Besides the evaluation of cultivable populations, analyses by DGGE revealed that the endophytic bacterial community from soybean roots may be influenced by the treatment of the soil with the glyphosate herbicide. Other analyzed aspect was the potential for plant growth promotion by 
soybean-associated bacteria; revealing that soybean's endophytic and epiphytic populations presented characteristics related to the plant growth promotion; factors such as cultivar and developmental stage of the host may influence the frequency of these populations. Environmental factors may affect the genetic variability of these bacterial populations. Besides, endophytic populations able to growth in medium containing glyphosate were characterized and identified as belonging to Burkholderia gladioli and Pseudomonas oryzihabitans species. Methylobacterium spp. were reintroduced in soybean seeds and superficial and endophytic colonization were evaluated by scanning electronic microscopy. The obtained results could offer a contribution for a better understanding of the interaction microorganism-soybean and, consequently, their possible use to improve soybean productivity. 


\section{INTRODUÇÃO}

As plantas podem ser consideradas um microecossistema complexo onde diferentes nichos são explorados por uma extensa variedade de bactérias. Neste aspecto, bactérias são habitantes comuns da superfície e do interior da maioria dos vegetais, podendo apresentar relações neutras e simbióticas com a planta hospedeira. As bactérias associadas às plantas são chamadas de endofíticas quando habitam o interior da planta hospedeira sem causar dano aparente ao hospedeiro e de epifíticas quando crescem e vivem sobre a superfície vegetal (rizoplano ou filoplano). Entretanto, há algumas populações bacterianas que podem flutuar entre a colonização endofítica e epifítica.

Os mecanismos envolvidos na interação bactérias-planta podem envolver diversos fatores bióticos e abióticos, os quais necessitam de mais estudos para um melhor entendimento e posterior utilização de suas propriedades. Desta forma, estudos de ecologia microbiana que buscam aumentar e consolidar os conhecimentos a respeito dos processos interativos no ambiente, podem auxiliar o entendimento deste processo, visto que já foi observado que estas bactérias podem conferir ao seu hospedeiro maior resistência a condições de estresse, alterações nas condições fisiológicas, proteção contra organismos patogênicos e herbívoros, além da produção de fitohormônios. Estes microrganismos também podem ser modificados geneticamente e introduzidos no hospedeiro conferindo características desejáveis ao mesmo. Atualmente, a capacidade de bactérias associadas às plantas em estimular o crescimento vegetal tem recebido especial atenção, pois estas bactérias podem influenciar o crescimento, desenvolvimento e saúde da 
planta por antagonismo a patógenos, produção de fitohormônios, fixação de nitrogênio, disponibilização de nutrientes, entre outros. Sabe-se também que diversos fatores ambientais podem atuar sobre esta comunidade benéfica para a planta hospedeira, sendo, portanto, de grande importância o conhecimento destes fatores e suas implicações para a agricultura.

Embora a cultura da soja (Glycine max) apresente grande importância econômica para o Brasil e o mundo, com exceção dos microrganismos fixadores de nitrogênio (noduladores), poucos estudos visando conhecer e obter aplicações práticas da interação microrganismos-planta foram feitas. Além disso, o intensivo uso de herbicidas para o controle de ervas daninhas juntamente com o desenvolvimento da soja transgênica (resistente ao herbicida glifosato) conduziu a uma crescente preocupação, visto que estes fatores poderiam interferir sobre os sistemas biológicos relacionados às plantas. Contudo, poucos estudos foram realizados para a avaliação dos possíveis efeitos destes herbicidas sobre a comunidade microbiana associada à soja.

Portanto, a utilização de bactérias endofíticas e epifíticas na produção agrícola irá depender do conhecimento sobre os mecanismos de interação bactéria-planta e da habilidade de manter, manipular e modificar populações benéficas sob condições de campo. Desta forma, torna-se evidente a necessidade de um melhor conhecimento sobre estes mecanismos de interação bactéria-planta. Diante do exposto, o presente trabalho teve como objetivos (i) isolar e caracterizar a comunidade bacteriana associada à soja; (ii) avaliar a possível influência de diferentes fatores, inclusive o tratamento do solo com aplicação pré-plantio do herbicida glifosato, sobre a comunidade bacteriana associada à soja; (iii) estudar mecanismos envolvidos na promoção de crescimento vegetal por bactérias endofíticas e epifíticas e avaliar a variabilidade genética destas bactérias; (iv) isolar e caracterizar bactérias capazes de crescer na presença do herbicida glifosato e (v) reintroduzir bactérias endofíticas em sementes de soja e avaliar a colonização destas bactérias sob microscopia eletrônica de varredura. 


\section{REVISÃO DE LITERATURA}

\subsection{Bactérias associadas às plantas}

\subsubsection{Aspectos gerais}

Bactérias são habitantes comuns da superfície e do interior da maioria dos vegetais, podendo apresentar relações neutras e simbióticas com a planta hospedeira. As bactérias associadas às plantas são chamadas de bactérias endofíticas quando habitam o interior da planta hospedeira sem causar dano aparente ao hospedeiro (Petrini, 1991; Hallmann et al., 1997b; Azevedo, 1998a, Sturz et al. 2000) e de bactérias epifíticas quando crescem e vivem sobre a superfície vegetal (rizoplano ou filoplano) (Petrini, 1991; Jacques \& Morris, 1995; Reinhold-Hurek \& Hurek, 1998; Andrews \& Harris, 2000).

Pode-se afirmar que as distinções entre bactérias endofíticas, epifíticas e fitopatogênicas são de natureza apenas didática, não existindo um claro limite entre grupos e sim um gradiente entre eles, visto que existem algumas populações bacterianas que podem flutuar entre a colonização endofítica e epifítica (Hallmann et al., 1997b). Dependendo das condições ambientais ou equilíbrio com outros endófitos, uma bactéria endofítica pode tornar-se um patógeno, uma bactéria epifítica pode, eventualmente, entrar numa planta e lá permanecer endofítica ou causando danos à mesma (Azevedo, 1998a; Azevedo et al., 2000b; Andrews \& Harris, 2000). Este aspecto pode ser melhor entendido com o trabalho de Whitesides \& Spotts (1991) que compararam características 
fenotípicas de isolados endofíticos e epifíticos da bactéria Pseudomonas syringae e relataram a capacidade de um mesmo isolado de se estabelecer dentro e fora do hospedeiro. Sabaratnam \& Beattie (2003) também avaliaram a colonização endofítica e epifítica de $P$. syringae e de Pantoea agglomerans, discutindo o processo de patogenicidade em relação à forma de colonização destas bactérias.

A origem, forma de penetração, colonização e transmissão de bactérias endofíticas ainda são muito discutidas. Elas podem ser provenientes de sementes, da rizosfera, do fitoplano e de material propagado vegetativamente (McInroy \& Klopper, 1995a; Hallmann et al., 1997b; Reinhold-Hurek \& Hurek, 1998). Sua penetração pode ocorrer pelos estômatos, ferimentos, áreas de emergências laterais das raízes, e podem produzir enzimas hidrolíticas capazes de degradar a parede celular dos vegetais, sendo este um possível mecanismo de penetração (Di Fiore \& Del Gallo, 1995; Quadt-Hallmann et al., 1997a; Shishido et al., 1999; McCully, 2001). As bactérias epifíticas podem ser oriundas das sementes, do solo, e/ou propagadas pelo ar, água e insetos (Andrews, 1992; Andrews \& Harris, 2000).

A colonização e distribuição de bactérias endofíticas e epifíticas no hospedeiro pode ser influenciada por interações com outros microrganismos associados à planta, nematóides parasitas e por características próprias de seu hospedeiro (Lindow \& Andersen, 1996; Quadt-Hallmann et al., 1997b; Hirano \& Hupper, 2000). Desta forma, o habitat associado à planta é um ambiente dinâmico, no qual diversos fatores podem influenciar a estrutura e composição da comunidade bacteriana associada ao vegetal. Pillay \& Nowak (1997) verificaram que em tomates, a colonização bacteriana endofítica e epifítica, in vitro, varia com as alterações na densidade do inóculo, temperatura e genótipo do hospedeiro. Outros fatores, tais como, variações sazonais, tipos de tecido vegetal (Mocali et al., 2003), cultivares e espécies de hospedeiro, tipo de solo (Dalmastri et al., 1999; Kinkel et al., 2000; Fromin et al., 2001) e interação com 
microrganismos benéficos ou patógenos (Araújo et al., 2001; Araújo et al., 2002) podem influenciar o padrão de colonização destas bactérias.

\subsubsection{Importância do estudo das bactérias endofíticas}

Os microrganismos endofíticos foram descritos pela primeira vez por Bary (1866), citado por Azevedo (1998a) e Peixoto-Neto et al. (2002), mas por mais de meio século estes microrganismos foram ignorados. Contudo, nos anos 70 do século $X X$, vários estudos demonstraram a interação mutualística entre endófitos e plantas. A partir de então, começou-se a avaliar qual o papel biológico exercido por estes microrganismos, visando sua aplicação biotecnológica.

As bactérias endofíticas têm sido isoladas de raiz, nódulos, caule, folhas e frutos em uma extensa variedade de plantas, incluindo muitas de interesse agrícola, tais como, cana-de-açúcar (Cavalcante \& Dobereiner, 1988), milho (Fisher et al., 1992; Mclnroy \& Kloepper, 1995b; Araújo et al., 2000), videira (Bell et al., 1995), algodão (Quadt-Hallmann et al., 1997a), arroz (Stolzfus et al., 1997), tomate (Pillay \& Nowak, 1997), citros (Araújo et al., 2001; Marcon, 2002), batata (Reiter t al., 2002), trigo e sorgo (Zinniel et al., 2002), entre outras. Segundo Misaghi \& Donndelinger (1990), as bactérias endofíticas possuem uma íntima relação com seus hospedeiros por meio de processos coevolutivos e podem ter influência na fisiologia das plantas por mecanismos ainda não completamente esclarecidos. Além disso, sua habilidade de sobreviver dentro de tecidos vegetais com pouca ou nenhuma competição microbiana, faz delas candidatas potenciais a aplicações biotecnológicas.

Várias são as razões para que investigações sejam conduzidas com bactérias endofíticas, entre elas pode-se citar: i) carência de informações nos aspectos ecológicos, genéticos e fisiológicos para elucidar a interação entre bactérias e plantas; ii) escassez de dados a respeito de bactérias endofíticas 
em plantas de clima tropical e subtropical, como o Brasil, em relação ao estudo de endófitos provenientes de plantas de clima temperado; iii) vários endófitos produzem antibióticos e outros metabólitos de interesse farmacológico (Azevedo et al., 2000b; Peixoto Neto et al., 2002; Marcon, 2002); iv) endófitos podem ser aplicados como agentes no controle biológico de pragas e de doenças (Azevedo et al., 2000a; Sutrz et al., 2000); v) endófitos podem ser usados como promotores de crescimento vegetal, produzindo fitohomônios, fixando $\mathrm{N}_{2}$ ou por outros mecanismos (Sturz et al., 2000); vi) endófitos podem ser utilizados como vetores para a expressão de genes heterólogos na planta hospedeira (Murray et al., 1992, Downing et al., 2000); vii) endófitos podem ser combinados em processo de fitorremediação de contaminantes orgânicos e metais pesados (Siciliano et al., 2001; Lodewyckx et al., 2002).

A utilização de bactérias endofíticas e epifíticas na produção agrícola irá depender do conhecimento sobre os mecanismos de interação bactéria-planta e da habilidade de manter, manipular e modificar populações benéficas sob condições de campo. Desta forma, torna-se evidente a necessidade de um melhor conhecimento sobre estes mecanismos de interação bactéria-planta, pois assim será possível a utilização prática destes microrganismos na agricultura, na indústria e em processos biotecnológicos.

\subsubsection{Aplicações biotecnológicas de bactérias endofíticas}

As bactérias endofíticas podem conferir ao seu hospedeiro, características como maior resistência a condições de estresse, alterações nas condições fisiológicas, suprimento de nitrogênio, produção de reguladores de crescimento vegetal e outros componentes de interesse biotecnológicos (como enzimas e drogas de interesse farmacêutico). As implicações práticas do estudo de endófitos se concentram, principalmente, no seu potencial para atuar na promoção de crescimento vegetal e no controle biológico de insetos-pragas ou 
de outros microrganismos (Sturz \& Matheson, 1996; Chanway, 1998; James, 2000; Azevedo et al., 2000a,b; Lodewyckx et al., 2002).

A união dos benefícios, que os endófitos podem fornecer aos seus hospedeiros, com as novas técnicas de biologia molecular tem sido alvo de alguns estudos que visam integrar características específicas em plantas via bactérias endofíticas. Um exemplo disto é o caso da bactéria endofítica Clavibacter xyli que foi modificada geneticamente com o gene da $\delta$-endotoxina de Bacillus thurigiensis (Bt), sendo depois inoculada em milho para controle da broca do colmo (Lampel et al., 1994; Tomasino et al., 1995). Outro exemplo é a transformação de uma linhagem de Bradyrhizobium com este gene de Bt. A bactéria modificada geneticamente foi introduzida em raízes de Cajanus cajan, resultando na proteção da planta hospedeira contra larvas de Rivelia angulata (Nambiar et al., 1990). Downing et al. (2000) também realizaram experimentos com o gene $\delta$-endotoxina de $B$. thuringiensis e com o gene chiA (quitinase) de Serratia marcescens, os quais foram introduzidos em Pseudomonas fluorescens (epifítica) e Herbaspirillum seropedicae (endofítica). Estes autores observaram um controle efetivo da broca da cana-de-açúcar (Eldana saccharina) pelas bactérias modificadas geneticamente.

Nos exemplos citados acima, a característica desejada foi a capacidade de controlar pragas agrícolas, mas, além desta, muitas outras características podem ser avaliadas. Entre estas possibilidades, pode-se citar que as bactérias endofíticas modificadas geneticamente poderiam ser utilizadas para o estudo de mecanismos de interação endófito-planta, para a promoção de crescimento vegetal, para a produção de enzimas e fármacos e para estudos de transferência gênica horizontal. Todavia, mais estudos sobre a ecologia e genética destes endófitos são necessários para a aplicação de microrganismos modificados no ambiente. 


\subsection{Mecanismos de promoção de crescimento vegetal}

Bactérias endofíticas e epifíticas podem contribuir para o crescimento, saúde e desenvolvimento vegetal. A promoção de crescimento vegetal por estas bactérias pode ser resultado tanto de ações indiretas, como o controle biológico por competição de nutrientes, produção de sideróforos, antibiose e indução de resistência sistêmica no hospedeiro (Sturz \& Matheson, 1996; Van Loon et al., 1998; Sturz et al., 2000; Ramamoorthy et al., 2001), como de ações diretas, como disponibilização de nutrientes para a planta, fixação de nitrogênio atmosférico e a produção de reguladores de crescimento vegetal (Glick, 1995; Chanway, 1998; Shishido et al., 1999; Sturz et al., 2000).

O mecanismo de promoção de crescimento vegetal por bactérias é um processo complexo que pode ser influenciado por diversos fatores bióticos e abióticos (Bloemberg \& Lugtenberg, 2001). Pillay \& Nowak (1997) avaliaram a densidade do inóculo, temperatura de cultivo e genótipo do hospedeiro como fatores envolvidos no processo de promoção de crescimento vegetal e observaram que estes fatores influenciaram os efeitos benéficos de bactérias endofíticas e epifíticas sobre plantas in vitro. Além disso, Sturz et al. (1998) verificaram que a promoção de crescimento vegetal por endófitos pode ser influenciada pela rotação de cultura. Neste aspecto, em um campo com rotação entre trevo e batata, foi observado que 25 espécies de bactérias endofíticas, pertencentes a 18 gêneros, foram comuns às duas plantas hospedeiras, promovendo o crescimento vegetal. Estas bactérias apresentaram também a capacidade de inibir in vitro o fungo Rhizoctonia solani, o qual é patógeno das duas culturas.

Freqüentemente quando se aborda 0 assunto de promoção de crescimento vegetal por bactérias, o grupo Rhizobiaceae é o primeiro a ser citado e um dos mais explorados. Entretanto, outros grupos bacterianos têm apresentado importante ação na promoção de crescimento vegetal. Neste contexto, Sturz (1995) verificou que bactérias endofíticas dos gêneros 
Pseudomonas, Bacillus, Xanthomonas, Agrobacterium, Actinomyces e Acinetobacter interagem com a planta hospedeira durante o processo de crescimento e tuberização da batata, evidenciando que grupos filogeneticamente distintos podem atuar nestes processos. Outro trabalho foi a caracterização de bactérias endofíticas (não Rhizobium) isoladas de nódulos de trevo vermelho. Estas bactérias promoveram o crescimento e desenvolvimento de plântulas do hospedeiro quando inoculadas isoladamente ou em combinação com Rhizobium. Essas observações indicam, portanto, que a promoção de crescimento vegetal é influenciada por outras bactérias que não pertencem ao grupo dos rizóbios (Sturz et al., 1997).

Bactérias que apresentam mais de uma característica para a promoção de crescimento vegetal, como, por exemplo, fixar nitrogênio e solubilizar fosfato ou produzir auxina e sideróforos, entre outras, são almejadas e rastreadas para uma possível aplicação no campo, objetivando o aumento da produção agrícola (Verma et al., 2001).

\subsubsection{Produção de reguladores de crescimento vegetal}

Os reguladores de crescimento vegetal são os hormônios vegetais (ou fitohormônios), ou seja, são reguladores naturais do crescimento das plantas, influenciando os processos fisiológicos em baixas concentrações. Os reguladores de crescimento vegetal podem ser classificados como auxinas (diferenciação celular, crescimento radicular, promoção de crescimento dos frutos e controle da abscisão), citocininas (regulação do crescimento, diferenciação e senescência vegetal), giberelinas (divisão e alongamento celular, interrupção da dormência e aumento do desenvolvimento dos frutos), ácido abscísico (regulação da transpiração, quebra de dormência e desenvolvimento inicial das sementes) e etileno (amadurecimento dos frutos, promoção da abscisão de folhas, flores e frutos e influência na expressão do 
sexo feminino) (Arshad \& Frankenberger-Jr, 1998; Raven et al., 2001). A produção destes reguladores já foi relatada em bactérias dos gêneros Gluconoacetobacter, Azospirillum, Herbaspirillum, Methylobacterium, Erwinia, Pantoea e Pseudomonas (Fuentes-Ramirez et al.,1993; Patten \& Glick, 1996; Lucangeli \& Bottini, 1997; Bastián et al., 1998; Cassán et al., 2001, Verma et al., 2001; Koenig et al., 2002), sendo portanto amplamente distribuído em bactérias associadas às plantas.

A produção de reguladores de crescimento vegetal é um mecanismo de interação bactéria-planta, sendo influenciado por vários fatores como o genótipo do hospedeiro e do próprio microrganismo. Este fato foi relatado por Jain \& Patriquin (1985), os quais mostraram que linhagens endofíticas puras de Azospirillum, ou filtrados das culturas, induzem a ramificação da raiz de trigo, sendo este fenômeno influenciado pelo genoma bacteriano ao nível de linhagem e pelo genoma da planta ao nível de cultivar. Estes autores isolaram e caracterizaram uma auxina (ácido indol acético - AIA) produzida pela bactéria, a qual apresentou relação com o efeito de ramificação da raiz.

A detecção de auxinas pode ser realizada por um método mais preciso e quantitativo, como o HPLC (cromatografia líquida de alta performance) ou por uma reação colorimétrica específica e sensível na qual utiliza-se o reagente de Salkowski, porém menos precisa quantitativamente (Ehmann, 1977; Crozier et al., 1988). Existem diferentes metodologias que utilizam o reagente de Salkowski, algumas utilizam microplacas, outras; membranas de nitrocelulose (Bric et al., 1991; Sarwar \& Kremer, 1995).

A produção de AIA, um regulador de crescimento vegetal que aparentemente não funciona como um hormônio em células bacterianas, pode ter evoluído devido a sua importância na relação bactéria-planta. Este regulador, quando secretado por bactérias, pode promover o crescimento da raiz diretamente pela estimulação da elongação da célula vegetal ou divisão celular, ou, indiretamente, pela influência sobre a atividade da ACC desaminase 
(1-aminociclopropano-1-carboxilato, um precursor do etileno) (Patten \& Glick, 2002).

A resposta das plantas ao AIA, liberada por bactérias, pode variar de efeitos benéficos a deletérios dependendo de sua concentração; quando em baixas concentrações, pode estimular e quando em altas concentrações, pode inibir o desenvolvimento da raiz vegetal. Os níveis de AIA produzidos pelas bactérias dependem do crescimento bacteriano, da atividade metabólica e da expressão de genes que codificam enzimas para a biossíntese de AIA (Lambrecht et al., 2000). Para a avaliação destes efeitos, diferentes metodologias estão sendo aplicadas, tais como, inocular raízes com bactérias mutantes quanto à produção de AIA ou aplicar inóculos bacterianos com diferentes concentrações. Patten \& Glick (2002) utilizaram a primeira metodologia citada e verificaram que Pseudomonas putida aumentou de $35 \%$ a $50 \%$ o crescimento primário das raízes de canola, devido à produção de AIA. Eles demonstraram diretamente que o AIA bacteriano tem um papel importante na elongação da raiz vegetal, quando a bactéria produtora está associada com sua planta hospedeira.

Além disso, estes pesquisadores (Patten \& Glick, 2002) deram um maior suporte à hipótese de que bactérias benéficas produzem AIA via ácido indolpirúvico (IPyA) em contraste com patógenos que produzem este composto via ácido indolacetamida (IAM) (Prinsen et al., 1993; Patten \& Glick, 1996, Manulis et al., 1998). Extensivas pesquisas têm sido realizadas com bactérias mutantes deficientes na síntese de AIA e os resultados demonstram a existência de mais de uma rota biossintética, dependente de triptofano, para a produção de AIA em um mesmo microrganismo. Estas vias biossintéticas são classificadas segundo seus compostos intermediários, como IAM ou IPya (Patten \& Glick, 1996; Dobbelaere et al., 1999). 


\subsubsection{Solubilização de fosfato inorgânico}

Após o nitrogênio, o fósforo $(P)$, apesar de ser abundante nos solos na forma orgânica e inorgânica, é o nutriente mais limitante do crescimento vegetal tendo em vista sua atuação estrutural, funcional, e na transferência de energia. Portanto, muitos tipos de solos são deficientes em $\mathrm{P}$ porque a concentração de fósforo livre (a forma disponível para as plantas), mesmo em solos férteis, é geralmente menor que $10 \mu \mathrm{M}$ em pH 6.5, onde o P está mais solúvel (Barroti \& Nahas, 2000; Gyaneshwar et al., 2002). As maiores reservas de P inorgânico são rochas e outros depósitos minerais, porém, uma considerável porção de $\mathrm{P}$ é acumulada em grande parte nos solos agrícolas em conseqüência de aplicações regulares de fertilizantes químicos. Contudo, quase a totalidade do fosfato inorgânico solúvel aplicado no solo é rapidamente imobilizada logo após sua aplicação, devido a sua alta reatividade com cálcio, ferro e alumínio, tornando-se indisponível para as plantas (Kumar \& Narula, 1999; Rodríguez \& Fraga, 1999). O segundo maior componente de $P$ no solo é de origem orgânica, contribuindo com $30 \%$ a $50 \%$, em média, na composição do $\mathrm{P}$ total no solo. $\mathrm{O}$ fósforo orgânico está geralmente na forma de fosfasto inositol (fitato), outras formas são fosfomonoésteres, fosfodiésters, incluindo fosfolipídios e ácidos nucléicos, e fosfotriésteres (Rodríguez \& Fraga, 1999; Gyaneshwar et al., 2002).

Os microrganismos, bactérias e fungos, têm um papel central no ciclo natural do P. Como citado anteriormente, o solo contém uma extensa variedade de substratos orgânicos que podem ser fonte de $\mathrm{P}$ para o crescimento vegetal. Entretanto, este $P$ deve ser hidrolisado para a forma inorgânica para poder tornar-se disponível para as plantas, processo este mediado por enzimas (fosfatases) produzidas principalmente por microrganismos (Rodriguéz et al., 2000; Gyaneshwar et al., 2002). Além disso, os microrganismos apresentam a capacidade de solubilizar fontes de $\mathrm{P}$ inorgânico, ou seja, as bactérias solubilizadoras de fosfato dissolvem o fosfato insolúvel pela produção de ácidos 
orgânicos e inorgânicos e/ou pela diminuição do pH; conseqüentemente, ocorre a produção de fosfato disponível que pode ser capturado pelas plantas (Nautiyal, 1999; Vazquez et al., 2000; Vassilev \& Vassileva, 2003).

Neste contexto, vários estudos têm sido realizados com a finalidade de avaliar microrganismos com capacidade de solubilizar fosfato inorgânico. Entre os gêneros bacterianos conhecidos com esta capacidade estão Pseudomonas, Burkholderia, Rhizobium, Agrobacterium, Azotobacter e Erwinia (Goldstein et al., 1999; Rodriguez \& Fraga, 1999; Rodriguez et al., 2000; Verma et al., 2001; Garg et al., 2001). Portanto, a habilidade de bactérias epifíticas e endofíticas em solubilizar fosfato inorgânico tem sido alvo de grande interesse por parte dos microbiologistas agrícolas, pois esta característica apresenta um grande potencial para a promoção de crescimento vegetal. É interessante salientar que as bactérias endofíticas com capacidade de solubilizar fosfato inorgânico ganham importância durante o processo de colonização, pois podem inicialmente colonizar superficialmente o hospedeiro e, conseqüentemente, provê-lo deste mineral essencial para o desenvolvimento vegetal.

Apesar de diversas bactérias solubilizadoras de fosfato ocorrerem no solo, freqüentemente seu número não é suficiente para competir com outras bactérias estabelecidas na rizosfera. Então, a quantidade de $\mathrm{P}$ liberada por elas, geralmente, não é o suficiente para um aumento substancial de crescimento vegetal. Portanto, o uso de bactérias solubilizadoras de fosfato como inoculantes é uma alternativa almejada para o aumento do desenvolvimento e produção vegetal (Rodriguéz \& Fraga, 1999; Gyaneshwar et al., 2002). Diversos trabalhos abordam a relação de bactérias solubilizadoras de fosfato com a promoção de crescimento vegetal em diversos hospedeiros; entre eles, pode-se citar Rhizobium leguminosarum promovendo o crescimento de milho (Chabot et al., 1998); Azotobacter chroococcum promovendo o crescimento de trigo (Kumar \& Narula, 1999); Pseudomonas fluorescens promovendo o crescimento de feijão (Katiyar \& Goel, 2003), entre outros. Um dos poucos trabalhos que abordam a capacidade de bactérias endofíticas em 
solubilizar fosfato inorgânico foi realizado por Verma et al. (2001), no qual relatam Pantoea agglomerans isoladas de raiz de arroz com esta característica.

\subsubsection{Fixação biológica de nitrogênio atmosférico}

As bactérias diazotróficas utilizam como fonte de nitrogênio para seu metabolismo o nitrogênio gasoso $\left(\mathrm{N}_{2}\right)$ da atmosfera $(>79 \%)$. O $\mathrm{N}_{2}$ é pouco reativo e somente algumas espécies de microrganismos procarióticos possuem o complexo enzimático, chamado nitrogenase, necessário para transformá-lo em amônia que é subseqüentemente assimilada em aminoácidos e proteínas. Este processo é chamado fixação biológica de $\mathrm{N}_{2}$ (FBN) (Neves \& Rumjanek, 1998; Zehr et al., 2003). Como estes microrganismos podem ser autotróficos ou heterotróficos, diferentes estratégias para armazenar energia (particularmente carboidratos) têm evoluído em associações simbióticas com as plantas, como em microrganismos fixadores de $\mathrm{N}_{2}$ de vida livre. Porém, observa-se que, em média, sistemas simbióticos apresentam uma capacidade maior de fixação, não apenas devido à energia promovida pela planta em forma de carboidratos, mas também devido a outras condições que são otimizadas para eficiente fixação de $\mathrm{N}_{2}$ (Cocking, 2003).

A exploração agrícola da FBN tem sido motivada pela conscientização ecológica sobre o uso intensivo e, às vezes, abusivo dos agroquímicos. Segundo Quispel (1988), o desenvolvimento de uma forma endofítica do microssimbionte é essencial na simbiose inter e intracelular entre plantas e microssimbiontes fixadores de $\mathrm{N}_{2}$, envolvendo para este desenvolvimento uma série de etapas na interação bactéria-planta.

A produção de soja no Brasil é um exemplo da eficiência da FBN, pois desde que foram realizados programas de melhoramento para fixação de $N_{2}$, tendo como resultado o desenvolvimento de inoculantes com linhagens de Rhizobium, nenhuma ou poucas aplicações de fertilizantes nitrogenados foram realizadas em solos cultivados com soja (Dobereiner, 1992; Dobereiner et al., 
1995; Alves et al., 2003). Entretanto, trabalhos recentes têm demonstrado que a presença de bactérias endofíticas (não Rhizobium) em nódulos de soja pode interferir na fixação de $\mathrm{N}_{2}$ (Bai et al., 2002; Bai et al., 2003). Estes dados resultam em perspectivas para maior exploração de bactérias endofíticas fixadoras de $\mathrm{N}_{2}$ em soja e em outras culturas.

Diversos trabalhos relatam bactérias endofíticas diazotróficas em diferentes hospedeiros (Tabela 1). Entretanto, a possibilidade de que bactérias fixadoras de $\mathrm{N}_{2}$ possam existir como endófitos nodulares tanto quanto vasculares, surgiu a partir de alguns trabalhos que exploram os elementos do xilema como possíveis sítios de fixação de $\mathrm{N}_{2}$. O xilema pode promover baixos níveis de oxigênio requerido para a FBN, bem como, sítios de trocas metabólitas que são necessários para a FBN (James, 2000). Alguns trabalhos reforçam a hipótese de que possa ocorrer expressão de genes envolvidos na fixação biológica de $\mathrm{N}_{2}$ no interior de tecidos vegetais. Entre estes trabalhos, estão os de Egener et al. (1999) que relata a expressão do gene nifH de Azoarcus sp. no interior de raízes de arroz e o de Chelius \& Tripplet (2000) que demonstra a expressão deste mesmo gene, porém, de Klebsiella pneumoniae, no interior de raízes de milho.

Tabela 1. Bactérias endofíticas diazotróficas oriundas de diferentes hospedeiros

\begin{tabular}{|c|c|c|}
\hline Hospedeiro & Espécies & Referências \\
\hline Milho & Klebsiella penumoniae & Palus et al., 1996 \\
\hline Café & Gluconoacetobacter diazotrophicus & Jimenez-Salgado et al., 1997 \\
\hline Arroz & $\begin{array}{l}\text { Azoarcus sp., Serratia marcescens, } \\
\text { Herbaspirillum sp. }\end{array}$ & $\begin{array}{l}\text { Egener et al., 1999; } \\
\text { Gyaneshwar et al., } 2001 ; \\
\text { Elbeltagy et al., } 2001\end{array}$ \\
\hline Crotalaria & Methylobacterium nodulans & Sy et al., 2001 \\
\hline $\begin{array}{l}\text { Cana-de- } \\
\text { açúcar }\end{array}$ & $\begin{array}{l}\text { G. diazotrophicus, Herbaspirillum } \\
\text { spp., Azoarcus spp. }\end{array}$ & $\begin{array}{l}\text { Reis-Junior et al., 2000; Reis } \\
\text { et al., 2000; Boddey et al., } \\
2003\end{array}$ \\
\hline
\end{tabular}




\subsection{Diversidade genética microbiana}

Os microrganismos apresentam imensa diversidade genética e desempenham funções únicas e cruciais na manutenção de ecossistemas, como componentes fundamentais de cadeias alimentares e ciclos biogeoquímicos (Myers, 1996). Apesar de sua grande importância, o número de grupos microbianos conhecidos e descritos (diversidade de espécies) representa apenas pequena fração da diversidade microbiana encontrada na natureza (Pace, 1997; Azevedo, 1998b). Dados derivados de estudos comparativos apontam para o fato de que apenas uma pequena fração dos microrganismos na natureza (entre $<0.1 \%$ a $1 \%$, dependendo do habitat) é cultivada através do emprego de métodos microbiológicos convencionais (Amann et al., 1995). Um grande número de fatores pode ser apontado para a dificuldade no cultivo de microrganismos em condições de laboratório, incluindo o pouco conhecimento sobre seus requisitos nutricionais e a biologia de organismos presentes em diferentes amostras ambientais.

A evolução das metodologias de biologia molecular aplicadas ao estudo do meio ambiente, tem contribuído significativamente para um grande avanço do conhecimento sobre a diversidade microbiana. Resultados de estudos independentes de isolamento e cultivo, baseados em amplificação e sequenciamento de fragmentos dos genes de rRNA 16S (rDNA 16S), demonstraram que a diversidade de microrganismos em amostras ambientais é vasta (Head, 1998; Hunter-Cevera, 1998). A aplicação destas metodologias no estudo da diversidade de bactérias tem permitido a descoberta de um número extenso de novas linhas evolutivas neste grupo. Métodos independentes de cultivo tendem a complementar os métodos baseados em isolamento e cultivo para a realização de levantamentos e comparações da composição, diversidade e estrutura de comunidades microbianas (Hugenholtz \& Pace, 1996; Hugenholtz et al., 1998; Ranjard et al., 2000). 
São vários os benefícios científicos esperados a partir de um melhor conhecimento sobre a diversidade microbiana são extensos (Colwell, 1997; Hunter-Cevera, 1998). Entre outros, estão a compreensão das funções exercidas pelas comunidades microbianas nos ambientes terrestres e 0 conhecimento de suas interações com outros componentes da biodiversidade, como por exemplo, as plantas. Neste aspecto, vários estudos têm explorado a diversidade de bactérias associadas às plantas, obtendo-se novas informações para o conhecimento de mecanismos envolvidos na interação bactéria-planta (Marilley \& Aragno, 1999; Araújo et al., 2001; Garbeva et al., 2001; Araújo et al., 2002; Sessitsch et al., 2002).

A aplicação de técnicas baseadas em ácidos nucléicos, tem auxiliado muitos estudos de diversidade microbiana. Dentre as técnicas mais utilizadas destacam-se: a) mapas de restrição; b) hibridização DNA-DNA ou DNA-RNA; c) seqüências de subunidades do rRNA; d) RAPD (Random Amplified Polymorphic DNA); e) ARDRA (Amplified Ribosomal DNA Restriction Analysis); f) RISA (Ribosomal Intergenic Spacer Analysis); g) DGGE (Denaturing Gradient Gel Electrophoresis) (Van Elsas et al., 1998; Muyzer \& Smalla, 1998; Ranjard et al., 2000). Embora exista um grande número de técnicas, que revelam polimorfismo de DNA, é importante considerar o tipo de organismo em estudo.

A técnica de RAPD utiliza iniciadores ou primers curtos e aleatórios que se anelam a diferentes locais no DNA genômico, gerando por PCR (Polymerase Chain Reaction) produtos de diferentes tamanhos (Williams et al., 1990; Welsh \& McClelland, 1990), sendo extremamente úteis para estudos de filogenia e caracterização de indivíduos (Louws et al., 1999), estudos da comunidade microbiana de ambientes aquáticos (Franklin et al., 1999) e bactérias endofíticas (Araújo et al., 2001). Oliveira et al. (2000) estudaram a diversidade genética de Rhizobium sp. associado a leguminosas, e Gonçalves \& Rosato (2000), de Xanthomonas sp. associada a maracujá, de diferentes locais. Esses autores observaram que as linhagens foram agrupadas preferencialmente de acordo com o local de origem. Araújo et al. (2001) utilizaram o RAPD para 
avaliar a diversidade genética de Pantoea agglomerans e Bacillus spp. endofíticos de diferentes espécies de citros e estes microrganismos formaram grupos independentes do hospedeiro. Com isso, observa-se que a técnica de RAPD pode ser utilizada para avaliar a diversidade genética dentro de grupos microbianos e associá-las ao nicho ocupado.

Outra técnica aplicada ao estudo da diversidade microbiana é o ARDRA, que consiste na amplificação e posterior digestão do rDNA com enzimas de restrição. Este método é baseado no princípio de que os sítios de restrição no rDNA são conservados de acordo com padrões filogenéticos. Desta forma, pode ser utilizado o 16S rDNA para o estudo de grupos heterogêneos, ou a região espaçadora entre o $16 \mathrm{~S}$ e o $23 \mathrm{~S}$ rDNA para o estudo de grupos muito similares (Heyndrickx et al., 1996; Van Elsas et al., 1998; Ranjard et al., 2000). Recentemente, a metodologia de ARDRA tem sido aplicada para o estudo da diversidade microbiana associada a vegetais ou a diferentes solos (Ovreas \& Torsvik, 1998; Chelius \& Triplett, 2001), análise da diversidade genética de bactérias degradadoras de pesticidas (Desaint et al., 2000) e caracterização de bactérias diazotróficas (Cruz et al., 2001), entre outras.

Técnicas moleculares baseadas no gene do $16 S$ rRNA têm sido utilizadas para a avaliação de comunidades microbianas não cultiváveis (Amann et al., 1995). Dentre estas técnicas, para o estudo de populações microbianas complexas, o DGGE identifica diferenças baseadas no comportamento desnaturante da dupla fita de DNA. Neste caso, o ambiente desnaturante é criado pela combinação uniforme da temperatura de corrida, variando entre $50^{\circ} \mathrm{C}$ e $65^{\circ} \mathrm{C}$, e um gradiente desnaturante linear de uréia e formamida (Heuer \& Smalla, 1997). O DGGE tem recebido especial atenção por ter sido utilizado com sucesso em diferentes habitats naturais (Muyzer et al., 1993; Brim et al., 1999; Fantroussi et al., 1999; Yang \& Crowley, 2000) e na detecção de variações na comunidade microbiana decorrente da presença de agroquímicos (Fantroussi et al., 1999), poluição (Brim et al., 1999), estado nutricional e fisiológico da planta hospedeira (Henckel et al., 1999; Yang \& 
Crowley, 2000) e também no estudo da comunidade microbiana associada a plantas transgênicas (Heuer \& Smalla, 1999) e bactérias endofíticas (Garbeva et al., 2001; Araújo et al., 2002). Desta forma, tais técnicas se mostram eficientes na avaliação da diversidade bacteriana e dos efeitos de alteração físico químicas do ambiente sobre a comunidade microbiana.

\subsection{A soja (Glycine max (L.) Merrill)}

\subsubsection{Importância econômica}

A soja cultivada é uma planta herbácea, ereta e cerrada, que pode atingir altura de $1,5 \mathrm{~m}$. Pertence à família Leguminosae, subfamília Papilionoideae e ao gênero Glycine L., que compreende cerca de quinze espécies, sendo classificada como Glycine max (L.) Merrill. Seu ciclo é anual e sua semeadura ocorre no início do ciclo das chuvas. Os estádios de

desenvolvimento da soja são divididos em vegetativos (estabelecimento e crescimento) e reprodutivos (florescimento e maturação). A Tabela 2 descreve detalhadamente cada estádio de desenvolvimento (Neumaier et al., 2000).

A soja foi domesticada pelos chineses há cerca de cinco mil anos e há três mil anos se espalhou pela Ásia, onde começou a ser utilizada como alimento. No início do século XX, a soja passou a ser cultivada comercialmente nos Estados Unidos e, a partir de então, houve um rápido crescimento na produção, com o desenvolvimento dos primeiros cultivares comerciais. Esta cultura foi introduzida no Brasil com os primeiros imigrantes japoneses em 1908, mas foi oficialmente mencionada no estado do Rio Grande do Sul em 1914. Entretanto, a expansão da soja no Brasil aconteceu nos anos 70 do século $\mathrm{XX}$, com o interesse crescente da indústria de óleo e a demanda do mercado internacional (Gomes, 1990; Alves et al., 2003; EMBRAPA/SOJA).

A importância desta cultura se deve às suas inúmeras aplicações na indústria alimentícia e farmacêutica. A aplicação primária do alimento de soja 
torrado desengordurado está na ração animal (97\%). A principal fração utilizada pela indústria de alimentos está no processamento do óleo de soja, que é empregado em margarinas, gorduras, óleos para cozinha e salada. A lecitina, um fosfatídio extraído do óleo da soja crua, é utilizada como emulsificante, lubrificante e agente estabilizador natural. O farelo de soja também é empregado em diversos produtos alimentícios, inclusive no tofu, no molho de soja e em produtos que simulam leite e carne. Existem poucas aplicações da soja não-processada em alimentos, uma vez que ela naturalmente contém inibidores de tripsina que podem atuar como antinutrientes se a soja não for adequadamente aquecida durante o preparo. As utilidades industriais da soja variam desde a produção de levedo e anticorpos até a fabricação de sabões e desinfetantes. Devido a estes fatores, a soja é, atualmente, uma das mais importantes leguminosas cultivadas no mundo (Gomes, 1990; EMBRAPA/SOJA).

Atualmente, o Brasil é o segundo maior produtor mundial de soja, contribuindo com $20 \%$ do total de soja produzida, sendo suplantado apenas pelos Estados Unidos da América (EUA). Na safra de 2002/03, a área cultivada com soja foi cerca de 18 milhões de hectares e produção de mais de 49 milhões de toneladas, representando um dos principais produtos básicos de exportação do país, com o envolvimento de cerca de US\$ 8 bilhões. Os principais estados produtores do Brasil são Mato Grosso, Paraná e Rio Grande do Sul, sendo responsáveis por, aproximadamente, 30 milhões de toneladas da produção de 2002/03. Além da representativa produção em números, o Brasil também se destaca por desenvolver cultivares de soja que apresentam eficiente relação simbiótica com a bactéria Bradyrhizobium japonicum, a qual realiza fixação biológica de $\mathrm{N}_{2}$, sendo possível, a partir de então, obter uma economia anual de mais de US\$ 2,5 bilhões com fertilizantes nitrogenados (Alves et al., 2003; EMBRAPA/SOJA). 
Tabela 2. Descrição sumária dos estádios fenológicos vegetativos (V) e reprodutivos $(\mathrm{R})$ de soja (Neumaier et al., 2000)

\begin{tabular}{|c|c|c|}
\hline \multicolumn{2}{|r|}{ Estádio } & \multirow{2}{*}{ Descrição } \\
\hline Símbolo & Denominação & \\
\hline VÊ & Emergência & Cotilédones acima da superfície do solo \\
\hline VC & Cotilédone & Cotilédones completamente abertos \\
\hline V1 & Primeiro nó & Folhas unifolioladas completamente desenvolvidas \\
\hline V2 & Segundo nó & Primeira folha trifoliolada completamente desenvolvida \\
\hline V3 & Terceiro nó & Segunda folha trifoliolada completamente desenvolvida \\
\hline V4 & Quarto nó & Terceira folha trifoliolada completamente desenvolvida \\
\hline V5 & Quinto nó & Quarta folha trifoliolada completamente desenvolvida \\
\hline V6 & Sexto nó & Quinta folha trifoliolada completamente desenvolvida \\
\hline $\mathrm{Vn}$ & Enésimo nó & $\begin{array}{l}\text { Anti-enésima folha trifoliolada completamente } \\
\text { desenvolvida }\end{array}$ \\
\hline $\mathrm{R} 1$ & $\begin{array}{l}\text { Início do } \\
\text { florescimento }\end{array}$ & Uma flor aberta em qualquer nó da haste principal \\
\hline $\mathrm{R} 2$ & $\begin{array}{l}\text { Florescimento } \\
\text { pleno }\end{array}$ & $\begin{array}{l}\text { Uma flor aberta em um dos } 2 \text { últimos nós da haste } \\
\text { principal com folha completamente desenvolvida }\end{array}$ \\
\hline R3 & $\begin{array}{l}\text { Início da formação } \\
\text { da vagem }\end{array}$ & $\begin{array}{l}\text { Vagem com } 5 \mathrm{~mm} \text { de comprimento em um dos } 4 \\
\text { últimos nós da haste principal com folha } \\
\text { completamente desenvolvida }\end{array}$ \\
\hline $\mathrm{R} 4$ & $\begin{array}{l}\text { Vagem } \\
\text { completamente } \\
\text { desenvolvida }\end{array}$ & $\begin{array}{l}\text { Vagem com } 2 \mathrm{~cm} \text { de comprimento em um dos } 4 \\
\text { últimos nós da haste principal com folha } \\
\text { completamente desenvolvida }\end{array}$ \\
\hline R5 & $\begin{array}{l}\text { Início do } \\
\text { enchimento do } \\
\text { grão }\end{array}$ & $\begin{array}{l}\text { Grão com } 3 \mathrm{~mm} \text { de comprimento em uma vagem em } \\
\text { um dos } 4 \text { últimos nós da haste principal, com folha } \\
\text { completamente desenvolvida }\end{array}$ \\
\hline R6 & $\begin{array}{l}\text { Grão verde ou } \\
\text { vagem cheia }\end{array}$ & $\begin{array}{l}\text { Uma vagem contendo grãos verdes preenchendo as } \\
\text { cavidades da vagem de um dos } 4 \text { últimos nós da haste } \\
\text { principal, com folha completamente desenvolvida }\end{array}$ \\
\hline $\mathrm{R} 7$ & $\begin{array}{l}\text { Início da } \\
\text { maturação }\end{array}$ & $\begin{array}{l}\text { Uma vagem normal na haste principal com coloração } \\
\text { de madura }\end{array}$ \\
\hline $\mathrm{R} 8$ & Maturação plena & 95\% das vagens com coloração de madura \\
\hline
\end{tabular}




\subsubsection{Bactérias endofíticas de soja}

O desenvolvimento da soja transgênica (resistente ao glifosato) gerou muitas dúvidas sobre a possibilidade de sua interferência nos sistemas biológicos relacionados a esta cultura. Embora a soja apresente grande importância econômica para o Brasil e para o mundo, com exceção das bactérias fixadoras de $\mathrm{N}_{2}$ (noduladoras), poucos estudos visando conhecer e avaliar o potencial biotecnológico da interação bactéria-planta foram desenvolvidos. Além disso, existe a necessidade de estudos sobre os efeitos do uso do glifosato sobre a comunidade microbiana associada à soja, visto que a aplicação deste herbicida pode aumentar com a utilização de plantas transgênicas, resistentes a este herbicida.

Os estudos de bactérias relacionadas à soja focalizam-se principalmente nas bactérias da rizosfera, que promovem o crescimento da planta hospedeira, e nas bactérias epifíticas com potencial para o controle biológico de pragas (Polonenko et al., 1987; O’Brien \& Lindow, 1989; May et al., 1997). Em relação às bactérias patogênicas que afetam a cultura da soja, Pseudomonas syringae pv. glycinea (crestamento bacteriano), P. syringae pv. tabaci (fogo selvagem) e Xanthomonas campestris pv. glycines (pústula bacteriana) são as principais espécies causadoras de doenças bacterianas em soja (Romeiro, 2000; Ullrich et al., 2000; Rukayadi et al., 2000). Contudo, poucos trabalhos abordam a associação entre bactérias endofíticas e soja, mas foi sugerido por Sinclair (1991) que infecções latentes por microrganismos em soja são resultado de processos co-evolutivos entre vegetal e patógeno, que permitem o acúmulo de genes de resistência e vigor no hospedeiro.

Segundo Saldanã et al. (2003), membros do gênero Bradyrhizobium foram conhecidos por muito tempo como os únicos simbiontes de soja. Porém, no início de 1980, alguns pesquisadores relataram outras espécies noduladoras em soja, sendo estas pertencentes ao gênero Sinorhizobium. Em recente 
trabalho, Bai et al. (2002) isolaram de nódulos de soja, cuja superfície foi previamente desinfectada, bactérias endofíticas pertencentes ao gênero Bacillus e observaram que estas linhagens quando co-inoculadas com $B$. japonicum estimularam a formação de nódulos. Estas mesmas linhagens também foram testadas quanto à capacidade de promover o crescimento vegetal em baixas temperaturas, obtendo-se resultados positivos (Bai et al., 2003). Outro estudo com bactérias endofíticas de soja, mas também relacionado a $B$. japonicum, foi realizado por Oehrle et al. (2000) que isolaram bactérias endofíticas de sementes que foram identificadas como Agrobacterium radiobacter, Aeromonas sp., Bacillus spp., Chryseomonas luteola, Flavimonas oryzihabitans (reclassificada como Pseudomonas oryzihabitans) e Sphingomonas paucimobilis. Além disto, estes autores avaliaram a interação da colonização destas bactérias com a colonização de $B$. japonicum e sugeriram que estes endófitos podem interferir no processo de nodulação.

O estudo de bactérias endofíticas de soja com potencial para o controle biológico de pragas foi realizado por alguns autores. Kloepper et al. (1991) avaliaram a densidade populacional e características fisiológicas de microrganismos da rizosfera e endofíticos da raiz de plantas (Mucuna deeringiana, Ricinus communis, Cannavalia ensiformis e Secale cereale) com propriedades antagonísticas a nematóides e fitopatógenos e compararam com a soja. Estes autores observaram que a densidade populacional foi semelhante entre as plantas, mas detectaram diferenças fisiológicas com os testes utilizados, sendo que a microbiota associada à soja apresentou os menores índices de atividade nos testes. Outro trabalho é o de Volksch et al. (1992) que estudaram a composição qualitativa e quantitativa da comunidade bacteriana no interior de folhas de soja, com lesões provocadas por $P$. syringae pv glycinea. Estes autores observaram que bactérias do gênero Erwinia apresentaram a capacidade de produzir metabólitos, os quais inibiram o patógeno, sendo um potencial agente para o controle biológico. Desta forma, o melhor conhecimento da comunidade bacteriana associada à soja poderá permitir o aproveitamento 
desta interação, viabilizando a utilização destas bactérias para o controle de patógenos ou promoção de crescimento vegetal.

\subsection{0 herbicida glifosato}

O desenvolvimento acelerado da agricultura tem levado ao aumento da necessidade do uso de pesticidas. Nos últimos anos, diversas alternativas foram criadas no sentido de reduzir esta necessidade. Entretanto, algumas mudanças, tais como o advento de alimentos transgênicos resistentes a algumas pragas, não resultaram na diminuição do uso de herbicidas, uma vez que não impedem o desenvolvimento de ervas daninhas no campo. Dentre os vários tipos de herbicidas, destacam-se aqueles de amplo espectro de ação, como é o caso dos não-seletivos. O glifosato [ $\mathrm{N}$-(fosfonometil)glicina] é classificado como herbicida não-seletivo, sistêmico, de amplo espectro e pósemergente, citado como o mais vendido em todo o mundo, em diferentes formulações, produzidas por distintas companhias de pesticidas e apresentando elevada eficiência na eliminação de ervas daninhas (Levesque \& Rahe, 1992; Borém, 1999; Amarante-Jr et al., 2002a,b).

O glifosato é rapidamente captado de aplicações foliares e translocado para as partes em crescimento das plantas. Este herbicida age por meio da inibição da enzima 5-enolpiruvilshiquimato-3-fosfato sintetase (EPSPs), inibindo a síntese dos aminoácidos aromáticos essenciais da via do ácido shiquímico como a fenilalanina, tirosina e triptofano, os quais são precursores de outros produtos, como lignina, alcalóides, flavonóides e ácidos benzóicos. Conseqüentemente, o glifosato influencia alguns processos que prejudicam a planta, como a inibição da síntese de clorofila e a redução do nível de ácido indol acético, causando um acumulo de amônia (Levesque \& Rahe, 1992; Penazola-Vazquez et al., 1995; Forlani et al., 1999).

A degradação do glifosato pode ocorrer devido à ação microbiológica, química e por irradiação ultravioleta. Há casos em que foi verificada a presença 
de $8 \%$ de glifosato no solo após dois anos de aplicação; outros relatos observaram a redução de 50\% deste herbicida aplicado após 60 dias. Estas variações são decorrentes do próprio solo, forma de aplicação e outras causas (Levesque \& Rahe, 1992; Dick \& Quinn, 1995; Penazola-Vazquez et al., 1995; Forlani et al., 1999; Haney et al., 2002). De acordo com Carlisle et al. (1988), o grau de degradação do glifosato está relacionado com o nível de respiração do solo, o qual revela uma estimativa da atividade microbiológica. Entre nove herbicidas testados, o glifosato foi o segundo mais tóxico, inibindo o crescimento (a 50 ppm) de 59\% de bactérias, fungos, actinomicetos e leveduras isolados aleatoriamente do solo. Além deste, outros trabalhos exploram a influência do glifosato sobre bactérias e fungos do solo (Levesque \& Rahe, 1992; Santos \& Flores, 1995; Krzysko-Lupicka \& Orlik, 1997; Nicholson \& Hirsch, 1998; Busse et al., 2001).

Este herbicida vinha sendo usado de forma não seletiva, mas com o advento dos organismos geneticamente modificados, ele passou a ser uma opção para o controle seletivo das plantas daninhas em várias culturas, principalmente da soja. Porém, apesar de já terem sido relatados alguns casos em que o glifosato atue sobre os microrganismos, escassos estudos têm sido realizados com o intuito de avaliar a influência deste herbicida na interação microrganismos-planta. Um dos poucos trabalhos, se não o único, que explora a influência deste herbicida sobre a comunidade microbiana endofítica é o de Prestidge \& Sprosen (1995), no qual os autores avaliaram a aplicação de glifosato em Lolium perenne colonizado pelo fungo endofítico Acremonium Iolii. Neste trabalho não foi observada alteração da concentração do alcalóide lolitrem B, produzido pelo endófito na planta hospedeira, mostrando que este herbicida não deve apresentar efeito sobre este fungo endofítico. Entretanto, com aumento da utilização deste herbicida é necessário uma melhor avaliação de seus possíveis efeitos sobre a comunidade microbiana associada às plantas.

Alguns dos possíveis fatores de risco ambiental devido ao uso intensivo do herbicida glifosato poderiam ser: modificações na biodiversidade microbiana 
do solo e associada à planta, efeito sobre a população microbiana promotora de crescimento vegetal, alteração do equilíbrio microrganismos-planta podendo causar um aumento de incidência de pestes, como insetos-pragas e microrganismos fitopatogênicos. Portanto, o conhecimento dos efeitos que este e outros herbicidas podem apresentar sobre populações microbianas benéficas associadas às plantas é importante não apenas para a manutenção do equilíbrio ecológico, mas também para o manejo de culturas agrícolas. 


\section{BACTÉRIAS ASSOCIADAS À SOJA: ISOLAMENTO, CARACTERIZAÇÃO E INTERAÇÃO BACTÉRIA-PLANTA}

\section{Resumo}

Apesar da soja (Glycine max) ser importante para a economia Brasileira e mundial, poucos estudos de interação microrganismos-planta foram realizados, com exceção dos microrganismos patogênicos e fixadores de $\mathrm{N}_{2}$ (rizóbio). Além disso, plantas de soja transgênicas tolerantes ao herbicida glifosato têm sido desenvolvidas, sugerindo que o uso deste herbicida na cultura da soja poderá aumentar significativamente. Considerando que bactérias podem ser afetadas pelo manejo da cultura, o iminente aumento do uso do herbicida glifosato na soja poderia alterar as comunidades bacterianas endofíticas e epifíticas deste hospedeiro. Desta forma, o objetivo do presente estudo foi avaliar o efeito dos fatores: aplicação de glifosato em pré-plantio, mudanças sazonais, cultivar, estádios de desenvolvimento da planta e tecidos vegetais, sobre as comunidades bacterianas endofíticas e epifíticas de soja. Bactérias endofíticas e epifíticas de folhas, caules e raízes de duas variedades de soja, cultivadas em solo com e sem aplicação de glifosato, foram amostradas em três estádios de desenvolvimento do hospedeiro, durante dois anos. Foram observadas diferenças significativas na diversidade e densidade bacteriana em relação às fases de crescimento e tecidos da planta. Foi observado que as principais bactérias associadas à soja pertenceram aos grupos Enterobacteriaceae, Pseudomonaceae e Burkholderiacea. Além disso, análise por DGGE de raízes revelou que a comunidade bacteriana endofítica é 
alterada pela aplicação de glifosato. Estes resultados sugerem que a relação bactéria-soja pode ser alterada por diferentes fatores, inclusive tratamento do solo com o herbicida glifosato. Finalmente, a melhor compreensão da interação entre populações bacterianas associadas às plantas é um fator importante para o manejo de culturas mais efetivo.

\section{Summary}

In spite of the soybean (Glycine max) crop to be economically important for Brazil and world, few studies concerning microorganisms-plant interaction have been accomplished, except for pathogens and nitrogen-fixing bacteria (rhizobia). Besides, transgenic soybean plants tolerant to glyphosate herbicide have been developed suggesting that the use of this herbicide will increase. Since such bacteria are affected by crop managing, the imminent increasing use of glyphosate herbicide in soybean crop could change the associated endophytic and epiphytic communities. The aim of the present study was to asses the effects of factors such as glyphosate application, seasonal changes, cultivar, plant growth stages, and plant tissues, on endophytic and epiphytic bacterial communities. Endophytic and epiphytic bacteria from leaves, stems, and roots of two soybean cultivars planted in soil with and without pre-planting glyphosate herbicide application were sampled at three different plant growth stages, during two years. Significant differences were observed in bacterial diversity and density in relation to soybean growth phases and plant tissues. The bacteria community associated to soybean included Enterobacteriaceae, Pseudomonaceae, and Burkholderiacea groups. Analyses by DGGE of soybean roots revealed that the endophytic community was affected by glyphosate treatment. These results suggest that the relationship between soybean and the endophytic and epiphytic bacterial community may be shift by different factors, including glyphosate herbicide treatment. Finally, a more complete 
comprehension of the interaction between plant-associated bacterial populations is an important factor for a more effective crop management.

\subsection{Introdução}

O desenvolvimento da soja transgênica (resistente ao glifosato) gerou dúvidas sobre a possibilidade de sua interferência nos sistemas biológicos relacionados a esta cultura. Embora a soja seja de grande importância econômica para o Brasil e o mundo, com exceção dos microrganismos patogênicos e fixadores de $\mathrm{N}_{2}$ (noduladores), poucos estudos visando conhecer e obter aplicações práticas da interação microrganismo-planta foram realizados. Além disso, existe a necessidade de estudos sobre os efeitos do uso do glifosato sobre a comunidade microbiana associada à soja, visto que a iminente liberação do cultivo de soja tolerante ao glifosato poderia ocasionar um aumento da aplicação deste herbicida.

Bactérias são habitantes comuns da superfície e do interior da maioria dos vegetais, podendo apresentar relações neutras e simbióticas com a planta hospedeira. As bactérias associadas às plantas são denominadas de bactérias endofíticas quando habitam o interior da planta hospedeira sem causar dano aparente ao hospedeiro (Petrini, 1991; Hallmann et al., 1997b; Azevedo, 1998b, Sturz et al. 2000) e de bactérias epifíticas quando crescem e se estabelecem sobre a superfície vegetal (rizoplano ou filoplano) (Petrini, 1991; Jacques \& Morris, 1995; Reinhold-Hurek \& Hurek, 1998; Andrews \& Harris, 2000).

Algumas populações bacterianas podem flutuar entre a colonização endofítica e epifítica (Hallmann et al., 1997b). Portanto, as distinções entre microrganismos endofíticos, epifíticos e fitopatogênicos são de natureza apenas didática, não existindo um claro limite entre grupos e sim um gradiente entre eles. Dependendo das condições ambientais ou equilíbrio com outros endófitos, um microrganismo endofítico pode tornar-se um patógeno, um microrganismo epifítico pode, eventualmente, entrar numa planta e lá permanecer endofítico ou 
causando danos à mesma (Azevedo et al., 2000b; Andrews \& Harris, 2000; Sabaratnam \& Beattie, 2003).

Bactérias endofíticas e epifíticas podem conferir ao seu hospedeiro, características como maior resistência a condições de estresse, alterações nas condições fisiológicas, fixação de nitrogênio atmosférico, indução de resistência sistêmica, produção de sideróforos, suprimento de nutrientes para a planta, produção de reguladores de crescimento vegetal e outros componentes de interesse biotecnológico (como enzimas e drogas de importância farmacêutica), desta forma contribuindo para o crescimento, saúde e desenvolvimento vegetal (Sturz \& Matheson, 1996; Chanway, 1998; Shishido et al., 1999; Azevedo et al., 2000a,b; Sturz et al., 2000; Ramamoorthy et al., 2001; Lodewyckx et al., 2002).

Portanto, a utilização de bactérias endofíticas e epifíticas na produção agrícola irá depender do conhecimento sobre os mecanismos de interação bactéria-planta e da habilidade de manter, manipular e modificar populações benéficas sob condições de campo (Hallmann et al., 1997b). Portanto, torna-se evidente a necessidade de um melhor conhecimento sobre estes mecanismos de interação bactéria-planta em soja, que poderá possibilitar a utilização prática destes microrganismos na cultura desta planta, bem como, na indústria e em processos biotecnológicos.

Desta forma, o presente trabalho teve como objetivos: (i) isolar e identificar bactérias endofíticas, epifíticas e do rizoplano de soja; (ii) avaliar a influência de diferentes fatores (variação sazonal, solo com e sem aplicação do herbicida glifosato, estádios de desenvolvimento do hospedeiro, genótipo da planta e tecido vegetal) sobre a comunidade bacteriana endofítica e epifítica; (iii) realizar a análise filogenética de isolados bacterianos endofíticos e epifíticos por meio da análise do sequenciamento parcial do 16S rDNA; e (iv) avaliar a comunidade bacteriana endofítica de raiz, por meio de PCR associado ao DGGE (Denaturing Gradient Gel Electrophoresis) do gene 16S rRNA. 


\subsection{Material e Métodos}

\subsubsection{Material vegetal}

Bactérias endofíticas e epifíticas foram isoladas de folha, caule e raiz de 2 cultivares, Foscarin (ciclo precoce) e Cristalina (ciclo tardio), de soja [Glycine $\max ($ L.) Merrill]. As amostras vegetais foram cultivadas na área experimental do Campus da Escola Superior de Agricultura "Luiz de Queiroz" - USP, Piracicaba/SP ( $22^{\circ} 42^{\prime}$ S e $\left.47^{\circ} 38^{\prime} \mathrm{W}\right)$, durante os anos agrícolas de 2000/01 e 2001/02. Foram utilizados dois lotes, um com aplicação pré-plantio do herbicida glifosato (1,44 Kg/ha Agrisato $480 \mathrm{CS}$ - Alkagro) e outro sem aplicação e histórico de aplicação do herbicida. Cada lote $(2 \times 6 \mathrm{~m})$ apresentou 10 linhas e 15 plantas por linha. $\mathrm{O}$ solo foi submetido à análise no Departamento de Solos e Nutrição de Plantas da ESALQ/USP, sendo classificado como argiloso e apresentando as seguintes características: $\mathrm{pH}$ 5,4 (água), 2,7 mmol/Kg potássio e $21,1 \mathrm{mg} / \mathrm{Kg}$ fósforo total. Para os isolamentos, 4 plantas de cada cultivar foram coletadas em três ocasiões durante os estádios: vegetativo (V6); florescimento (R2); e maturação (R6) de desenvolvimento vegetal (Neumaier et al. 2000).

\subsubsection{Processamento das amostras e isolamento de bactérias associadas à soja}

As amostras de soja foram removidas do solo e levadas em sacos plásticos para o laboratório, onde foram imediatamente processadas. As plantas foram lavadas em água corrente para a retirada do solo agregado às raízes e separadas em folha, caule e raiz.

Para o isolamento de bactérias epifíticas e do rizoplano, $3 \mathrm{~g}$ de tecido foram colocados em frascos Erlenmeyer $(500 \mathrm{ml})$ contendo $25 \mathrm{~g}$ de pérolas de vidro $(0,1 \mathrm{~cm}$ de diâmetro - Sigma) e $50 \mathrm{ml}$ de tampão PBS $(1,44 \mathrm{~g} / \mathrm{l}$ de 
$\mathrm{Na}_{2} \mathrm{HPO}_{4} ; 0,24 \mathrm{~g} / \mathrm{l}$ de $\mathrm{KH}_{2} \mathrm{PO}_{4} ; 0,20 \mathrm{~g} / \mathrm{l}$ de $\mathrm{KCl} ; 8,00 \mathrm{~g} / \mathrm{l}$ de NaCl$\left.; \mathrm{pH} 7,4\right)$. Estes frascos foram mantidos sob agitação $(100 \mathrm{rpm})$ a $28^{\circ} \mathrm{C}$ por $1 \mathrm{~h}$. Em seguida, diluições apropriadas em tampão PBS foram semeadas em TSA 10\% (Trypcase Soy Agar) suplementado com o fungicida Imazalil ( $50 \mu \mathrm{g} / \mathrm{ml})$.

Após a retirada das bactérias epifíticas, as bactérias endofíticas foram isoladas por meio de desinfecção superficial dos tecidos, que consistiu nas seguintes etapas: lavagem por $1 \mathrm{~min}$ em etanol 70\%; $3 \mathrm{~min}$ em hipoclorito de sódio $(\mathrm{NaOCl})$ a $2 \%$ de cloro ativo $(\mathrm{v} / \mathrm{v})$ acrescido de Tween $20(1 \mathrm{ml} / \mathrm{l})$ e $30 \mathrm{seg}$ em etanol $70 \%$, seguido de duas lavagens em água destilada esterilizada. Os tecidos foram cortados, assepticamente, em pequenos fragmentos e triturados em $10 \mathrm{ml}$ de tampão PBS com o auxílio de cadinhos e almofarizes. Em seguida, todo o material foi transferido para tubos de $15 \mathrm{ml}$ e incubados sob agitação (150 rpm) a $28^{\circ} \mathrm{C}$ por $1 \mathrm{~h}$. Diluições apropriadas em tampão PBS foram semeadas em TSA $10 \%$ suplementado com o fungicida Imazalil $(50 \mu \mathrm{g} / \mathrm{ml})$.

Foram utilizadas quatro plantas de cada cultivar e cinco placas de Petri por tecido vegetal. As placas foram incubadas a $28^{\circ} \mathrm{C}$ e avaliadas com 2 , 8 e 15 dias de crescimento. Para confirmar que o processo de desinfecção foi bem sucedido, alíquotas da água destilada utilizada na última lavagem foram semeadas em TSA $10 \%$ suplementado com o fungicida Imazalil $(50 \mu \mathrm{g} / \mathrm{ml})$ e incubadas a $28^{\circ} \mathrm{C}$ por $4-15$ dias.

A população bacteriana por grama de tecido vegetal fresco (UFC/g TVF) foi estimada pela contagem de colônias cultivadas em meio TSA $10 \%$. Colônias bacterianas foram repicadas das placas de isolamento, purificadas e mantidas em TSA $10 \%$ suplementado com $20 \%$ de glicerol a $-70^{\circ} \mathrm{C}$. Colônias características de cada tipo morfológico foram repicadas e selecionadas para estocagem. 


\subsubsection{Identificação dos isolados bacterianos}

Os isolados bacterianos foram agrupados por características morfológicas e por ribotipagem. Isolados representativos de cada grupo foram identificados por análise da seqüência parcial do 16S rDNA ou enviados ao "Bacteria Collection Laboratorium voor Microbiologie - Universiteit Ghent Belgium" para identificação por análise de ácidos graxos totais da célula bacteriana (FAME - Fatty Acid Methyl Esters), feitas por cromatografia e pelo sistema MIDI (Microbial Identification System, Inc., Delaware, USA). Os isolados que não puderam ser identificados por FAME foram ensaiados por BIOLOG (Biolog Inc., California, USA) ou pelo perfil de índice analítico (API - AP 20E e AP50CHE, Bio Mérieux S.A., France).

\subsubsection{Extração de DNA genômico de bactérias}

As linhagens foram cultivadas em $5 \mathrm{ml}$ de TSA $10 \%$ líquido por $24 \mathrm{~h}$ a $28^{\circ} \mathrm{C}$ sob agitação de $150 \mathrm{rpm}$. Dois a $4 \mathrm{ml}$ da cultura foram centrifugados por 5 min a $14000 \mathrm{~g}$ e as células ressuspendidas em $500 \mu \mathrm{l}$ de TE (10 mM de Tris$\mathrm{HCl}$; $\mathrm{pH} 8,0$ ), centrifugadas e ressuspendidas novamente em $500 \mu \mathrm{l}$ de TE com o acréscimo de $0,5 \mathrm{~g}$ de pérolas de vidro $(0,1 \mathrm{~mm}$ de diâmetro - Sigma) e $15 \mu \mathrm{l}$ de SDS $20 \%$. As células foram agitadas em um homogeneizador (MineBeadbeater $^{T M}$, Biospec Products) por $30 \mathrm{~s}$ a 3500 bpm. Ao lisado celular foram adicionados $500 \mu \mathrm{l}$ de fenol, homogeneizados por inversão e centrifugado por 5 min a $14000 \mathrm{~g}$. A fase aquosa foi extraída uma vez com fenol-clorofórmio (1:1) e uma vez com clorofórmio, então, o DNA foi precipitado com 1/10 volume de $\mathrm{NaCl} 5 \mathrm{M}$ e 0,6 volume de isopropanol (3 min à temperatura ambiente) e coletado por centrifugação (10 min a 14000 g). O precipitado de DNA foi lavado com etanol $70 \%$, seco a $37^{\circ} \mathrm{C}$ e ressuspendido em $50 \mu \mathrm{l}$ de água milli-Q esterilizada. O DNA total foi analisado por eletroforese em gel de agarose $(0,8 \%$ 
p/v) em tampão 1x TAE (40 mM de Tris-acetato; 1 mM de EDTA) e corado com brometo de etídio $(0,5 \mu \mathrm{g} / \mathrm{ml})$, segundo Sambrook et al. (1989).

\subsubsection{Extração de DNA total de tecidos vegetais}

Após desinfecção superficial das raízes, durante o processo de isolamento de bactérias endofíticas, $2 \mathrm{ml}$ do material vegetal triturado foram centrifugados por $5 \mathrm{~min}$ a $14000 \mathrm{~g}$, o precipitado foi ressuspendido em $500 \mu \mathrm{l}$ de TE com o acréscimo de $0,5 \mathrm{~g}$ de pérolas de vidro $(0,1 \mathrm{~mm}$ de diâmetro Sigma) e $15 \mu \mathrm{l}$ de SDS 20\%. Esta suspensão foi agitada em homogeneizador de células por $30 \mathrm{~s}$ a $3500 \mathrm{bpm}$. Foram adicionados $500 \mu \mathrm{l}$ de fenol, homogeneizados por inversão e centrifugado por $10 \mathrm{~min}$ a $14000 \mathrm{~g}$. A fase aquosa foi extraída uma vez com fenol-clorofórmio (1:1) e uma vez com clorofórmio, então, o DNA foi precipitado com 1/10 volume de $\mathrm{NaCl} 5 \mathrm{M}$ e 0,6 volume de isopropanol (5 $\mathrm{min}$ à temperatura ambiente) e coletado por centrifugação (15 min a $14000 \mathrm{~g}$ ). O precipitado de DNA foi lavado com etanol $70 \%$, seco a $37^{\circ} \mathrm{C}$ e ressuspendido em $50 \mu$ de água milli-Q esterilizada. $\mathrm{O}$ DNA total foi analisado por eletroforese com gel de agarose $(0,8 \% \mathrm{p} / \mathrm{v})$ em tampão 1x TAE e corado com brometo de etídio $(0,5 \mu \mathrm{g} / \mathrm{ml})$.

\subsubsection{Amplificação, restrição, sequenciamento e análise do 16S rDNA}

A amplificação do $16 \mathrm{~S}$ rDNA foi realizada por meio da técnica de PCR utilizando-se os primers universais para bactérias P027F (5'GAGAGTTTGATCCTGGCTCAG-3') e 1378R (5'CGGTGTGTACAAGGCCCGGGAACG-3'). As reações apresentaram um volume final de $50 \mu$ l contendo 0,5 a $10 \mathrm{ng}$ de DNA molde; 0,2 $\mu \mathrm{M}$ de cada primer; 0,2 mM de cada dNTPs; 3,75 mM de $\mathrm{MgCl}_{2}$ e 0,05 $\mathrm{U}$ da enzima Taq DNA polimerase (Invitrogen) em $20 \mathrm{mM}$ de Tris- $\mathrm{HCl}$ pH 8,4 e $50 \mathrm{mM} \mathrm{KCl}$. Em todas as reações foi utilizado um controle negativo sem o DNA molde. 
A reação de amplificação foi realizada em termociclador (Perkin-Elmer GeneAmp ${ }^{\circledR}$ PCR System 9700) programado para realizar uma desnaturação inicial a $94^{\circ} \mathrm{C}$ por 4 min, 25 ciclos de desnaturação a $94^{\circ} \mathrm{C}$ por $30 \mathrm{~s}$, anelamento a $63^{\circ} \mathrm{C}$ por 1 min e extensão de primers a $72^{\circ} \mathrm{C}$ por $1 \mathrm{~min}$, seguida de extensão final a $72^{\circ} \mathrm{C}$ por $7 \mathrm{~min}$. Após a amplificação, $5 \mu \mathrm{l}$ da reação de PCR foram avaliados por eletroforese em gel de agarose $(1,2 \%$ p/v) em tampão 1x TAE e corado com brometo de etídio $(0,5 \mu \mathrm{g} / \mathrm{ml})$, para visualização de um fragmento de aproximadamente $1350 \mathrm{pb}$.

A ribotipagem do $16 \mathrm{~S}$ rDNA foi obtida pela utilização da técnica de ARDRA (Amplified Ribosomal DNA Restriciton Analysis). Para isso, $1 \mu \mathrm{g}$ do fragmento de $16 \mathrm{~S}$ rDNA amplificado foi clivado com a enzima de restrição Alul, de acordo com as recomendações do fabricante (Invitrogen). Após a digestão, toda a reação foi analisada por eletroforese em gel de agarose $(2,5 \% \mathrm{p} / \mathrm{v}) \mathrm{em}$ tampão 1x TAE, juntamente com o marcador de peso molecular DNA Ladder 100 pb (Life Technologies). Em seguida, o gel foi corado com brometo de etídio $(0,5 \mu \mathrm{g} / \mathrm{ml})$, observado sobre luz ultravioleta e fotodocumentado.

Para a identificação de isolados representantes dos haplótipos obtidos pela técnica de ARDRA, os produtos de PCR 16S rDNA foram purificados (GFX PCR DNA and gel band purification kit, Amersham Biosciences) e enviados para sequenciamento parcial do $16 \mathrm{~S}$ rDNA com o primer 1378R, no Laboratório do Dr. Ricardo Harakava (Instituto Biológico/USP). As seqüências foram analisadas pelo BLASTn contra a base de dados do NCBI (National Center for Biotechnology Information website [http://www.ncbi.nlm.nih.gov]) e pelo programa ARB (Department of Microbiology, Technical University of Munich, Munich, Germany [http://www.arb-home.de]), que construiu as árvores filogenéticas. As seqüências foram depositadas no banco de dados do NCBI (GenBank) sob os seguintes números de acesso: AY487809 a AY487818 e AY489067 a AY489107. 


\subsubsection{PCR e análise por DGGE}

As reações de PCR para análise de DGGE foram realizadas em um volume final de $50 \mu \mathrm{l}$, contendo 0,5 a $10 \mathrm{ng}$ de DNA molde; $0,2 \mu \mathrm{M}$ dos primers U968GC (5'-CGCCCGGGGCGCGCCCCGGGCGGGGCGGGGCACGGGGGGAACGCGAAGACCTTAC-3') e R1378, que são específicos para o gene $16 \mathrm{~S}$ rRNA; 0,2 mM de cada dNTPs; $3,75 \mathrm{mM}$ de $\mathrm{MgCl}_{2}$ e $0,05 \mathrm{U}$ da enzima Taq DNA polimerase (Invitrogen) em $20 \mathrm{mM}$ de Tris- $\mathrm{HCl}$ pH 8,4 e $50 \mathrm{mM} \mathrm{KCl}$. Em todas as reações foi utilizado um controle negativo sem o DNA molde.

A reação de amplificação foi realizada no termociclador (Perkin-Elmer GeneAmp ${ }^{\circledR}$ PCR System 9700) programado para realizar uma desnaturação inicial de 4 min a $94^{\circ} \mathrm{C}, 2$ ciclos de $1 \min$ a $94^{\circ} \mathrm{C}, 1 \mathrm{~min}$ a $60^{\circ} \mathrm{C}$ e $2 \min$ a $72^{\circ} \mathrm{C}, 2$ ciclos de $1 \mathrm{mim}$ a $94^{\circ} \mathrm{C}, 1 \mathrm{~min}$ a $59^{\circ} \mathrm{C}$ e 2 min a $72^{\circ} \mathrm{C}, 2$ ciclos de $1 \mathrm{mim}$ a $94^{\circ} \mathrm{C}$, $1 \mathrm{~min}$ a $58^{\circ} \mathrm{C}$ e $2 \min$ a $72^{\circ} \mathrm{C}, 2$ ciclos de $1 \mathrm{mim}$ a $94^{\circ} \mathrm{C}, 1 \mathrm{~min}$ a $57^{\circ} \mathrm{C}$ e $2 \mathrm{~min}$ a $72^{\circ} \mathrm{C}, 2$ ciclos de $1 \mathrm{mim}$ a $94^{\circ} \mathrm{C}, 1 \mathrm{~min}$ a $56^{\circ} \mathrm{C}$ e 2 min a $72^{\circ} \mathrm{C}, 20$ ciclos de 1 mim a $94^{\circ} \mathrm{C}, 1 \mathrm{~min}$ a $55^{\circ} \mathrm{C}$ e $2 \min$ a $72^{\circ} \mathrm{C}$ e uma extensão final de $10 \mathrm{~min}$ a $72^{\circ} \mathrm{C}$. Cinco $\mu \mathrm{l}$ da reação de PCR foram avaliados por eletroforese em gel de agarose $(1,2 \%$ p/v) em tampão 1x TAE e corado com brometo de etídio $(0,5$ $\mu \mathrm{g} / \mathrm{ml}$ ), para visualização de um fragmento de aproximadamente $450 \mathrm{pb}$.

A análise por DGGE, baseada no método descrito por Muyzer et al. (1993), foi realizada no sistema DGGE-1001 (C.B.S., Scientific Company, Inc., USA). Os produtos de PCR foram colocados em gel de poliacrilamida (6\% acrilamida) vertical, com um gradiente de uréia/formamida ( $45 \%$ a $80 \%$ ), onde $100 \%$ de desnaturação apresenta $7 \mathrm{M}$ de uréia e $80 \%$ de formamida. Foi aplicada uma corrente elétrica de 100 volts por 15 horas. Após a eletroforese, o gel foi corado com SYBR Green (diluído de 1:10.000; Gold Nucleic Acid Gel Stain; Molecular Probes, Eugene, Oregon, USA) diluído em tampão 1x TAE, observado sobre luz ultravioleta e fotodocumentado. 
Bandas de interesse foram cortadas, homogeneizadas em $10 \mu \mathrm{l}$ água milli-Q esterilizada e submetidas à nova reação de amplificação (nas mesmas condições do PCR - DGGE, porém, utilizando-se a solução das bandas como DNA molde). Os produtos da reamplificação foram purificados e enviados para sequenciamento com o primer U968GC, no Laboratório do Dr. Ricardo Harakava. As seqüências foram analisadas pelo BLASTn contra a base de dados do NCBI (National Center for Biotechnology Information website [http://www.ncbi.nlm.nih.gov]), no qual foi observada a similaridade destas seqüências com regiões $16 S$ rDNA já depositadas no banco de dados.

\subsubsection{Análise estatística}

A análise estatística foi feita com o auxílio do programa SAS (Proc GLM no SAS Copyright (c) 1989-1996; SAS Institute, Cary, NC, USA). A ANOVA foi analisada com delineamento experimental inteiramente casualizado, incluindo parcela perdida, a qual testou hipóteses a 1\% de significância (Steel \& Torrie, 1980). Os valores de UFC/g TVF foram transformados em $\log _{10}$ de $X+1$ antes da análise de variância. $O$ teste de Tukey foi aplicado para comparação entre as médias.

\subsection{Resultados}

\subsubsection{Avaliação da comunidade bacteriana cultivável endofítica e epifítica de soja}

A presença de bactérias endofíticas e epifíticas de folhas, caules e raízes de duas cultivares de soja foi determinada durante os estádios de desenvolvimento vegetal V6, R2 e R6 de plantas crescidas em solo com e sem aplicação em pré-plantio do herbicida glifosato, nas safras de 2000/01 e 2001/02. Durante os experimentos, não foi observada a presença de 
crescimento bacteriano nas placas do controle da desinfecção superficial, mostrando que a metodologia utilizada eliminou a comunidade epifítica cultivável dos tecidos vegetais.

A densidade total da comunidade bacteriana endofítica e epifítica variou em torno de $10^{4}$ a $10^{6} \mathrm{UFC} / \mathrm{g}$ TVF e $10^{8}$ a $10^{10} \mathrm{UFC} / \mathrm{g}$ de TVF, respectivamente. Porém, esta densidade sofreu interação com alguns fatores analisados, tais como, variação sazonal (safras); cultivar; estádios de desenvolvimento do hospedeiro; e tecidos vegetais.

Foi observado que os estádios fisiológicos V6, R2 e R6, sob diferentes condições ambientais, afetaram significativamente a densidade populacional bacteriana. A fases R2 e R6 (florescimento e maturação fisiológica, respectivamente) apresentaram maior densidade populacional, tanto para a população bacteriana epifítica quanto para a endofítica, durante a safra de 2000/01 (Figura 1).

Além disto, foi observado que a comunidade bacteriana endofítica aumentou de acordo com o desenvolvimento do hospedeiro, na cultivar Cristalina que apresenta um ciclo mais longo (Figura 2B). Entretanto, a comunidade bacteriana epifítica foi menos afetada por esta variação, apresentando um aumento tênue nas fases iniciais de desenvolvimento da cultivar Foscarin (Figura 2A).

Em relação ao tratamento do solo com o herbicida glifosato, houve interação apenas com a densidade bacteriana epifítica, durante 0 desenvolvimento do hospedeiro (Figura 3 ). Foi observado que a comunidade bacteriana epifítica oriunda de plantas em fase $V 6$ foi influenciada pelo tratamento do solo, pois, a densidade populacional de bactérias epifíticas foi maior quando estas baterias foram isoladas de plantas cultivadas em solo com aplicação de glifosato (Figura 3). Outra interação observada foi em relação aos tecidos do hospedeiro, pois, a análise dos dados mostrou que a densidade bacteriana endofítica diminui na direção raiz>caule>folha, sendo este perfil também observado para a comunidade epifítica/rizoplano (Figura 4). 

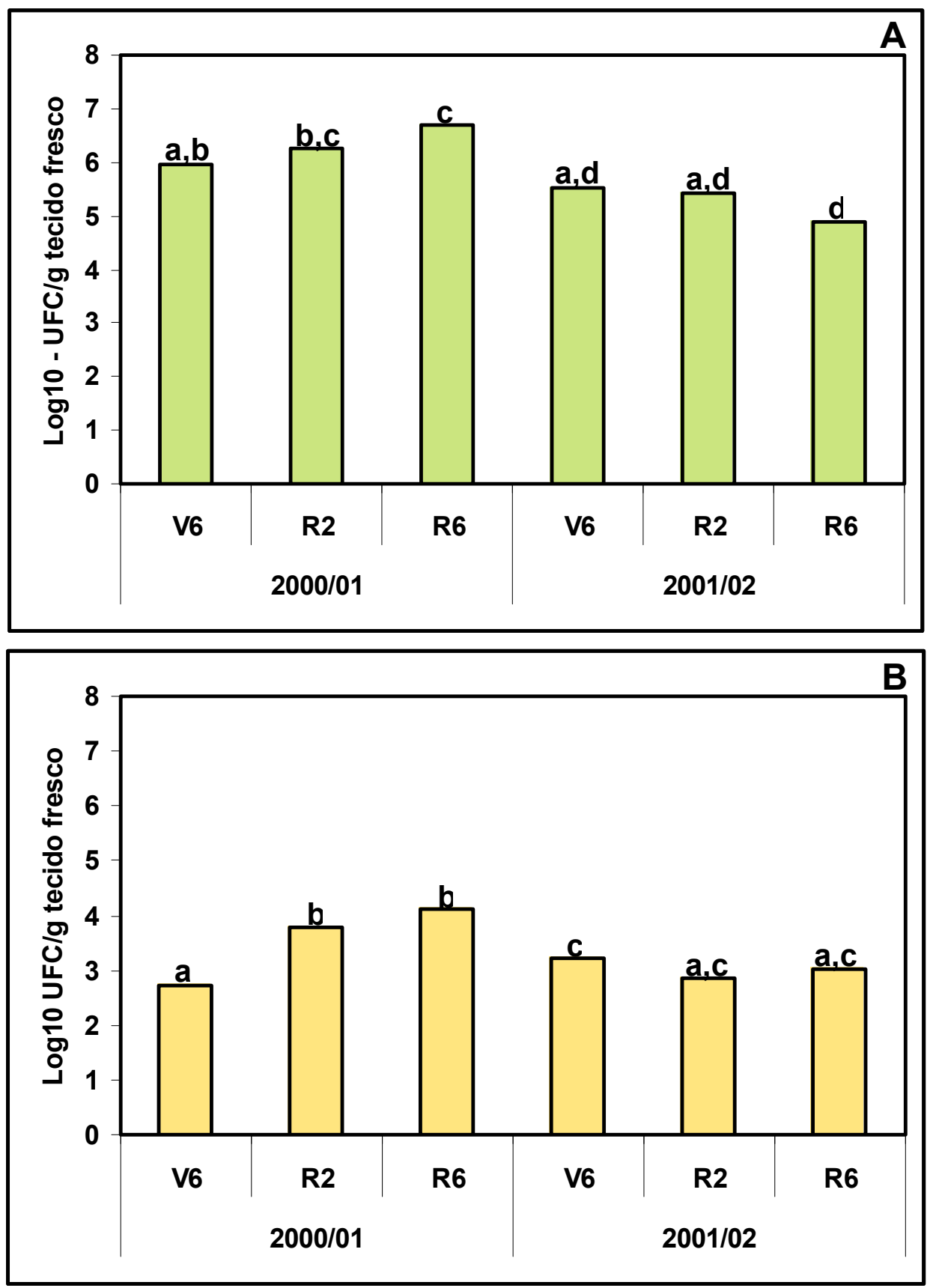

Figura 1 - Densidade populacional total da comunidade bacteriana epifítica (A) e endofítica (B) de soja durante as fases: V6; R2 e R6, nas safras 2000/2001 e 2001/2002. Médias com a mesma letra não são significativamente diferentes pelo teste de Tukey $(P>0.01)$ 

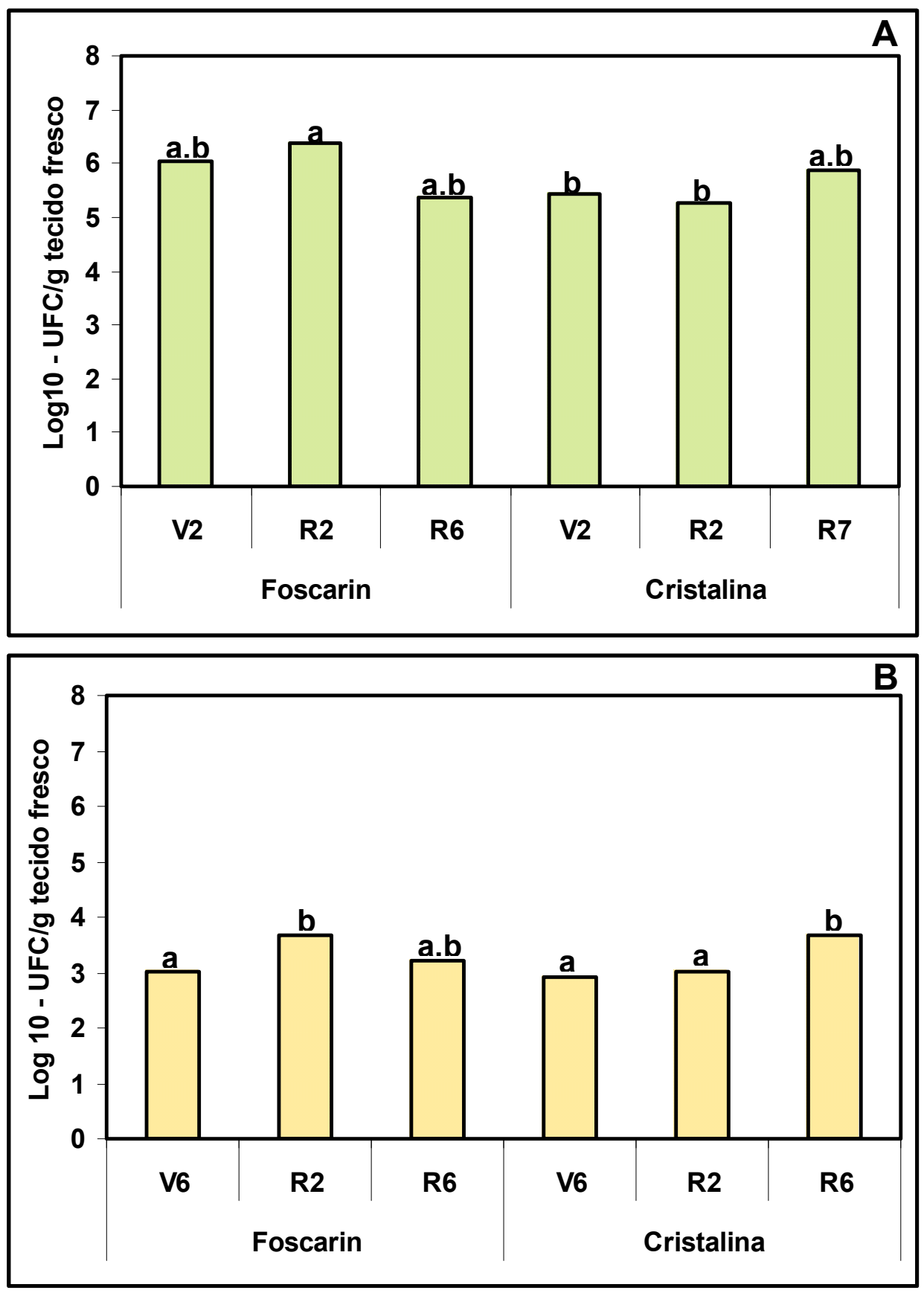

Figura 2 - Densidade populacional total da comunidade bacteriana epifítica (A) e endofítica (B) de soja durante as fases: V6; R2 e R6, nas cultivares Foscarin e Cristalina. Médias com a mesma letra não são significativamente diferentes pelo teste de Tukey $(P>0.01)$ 


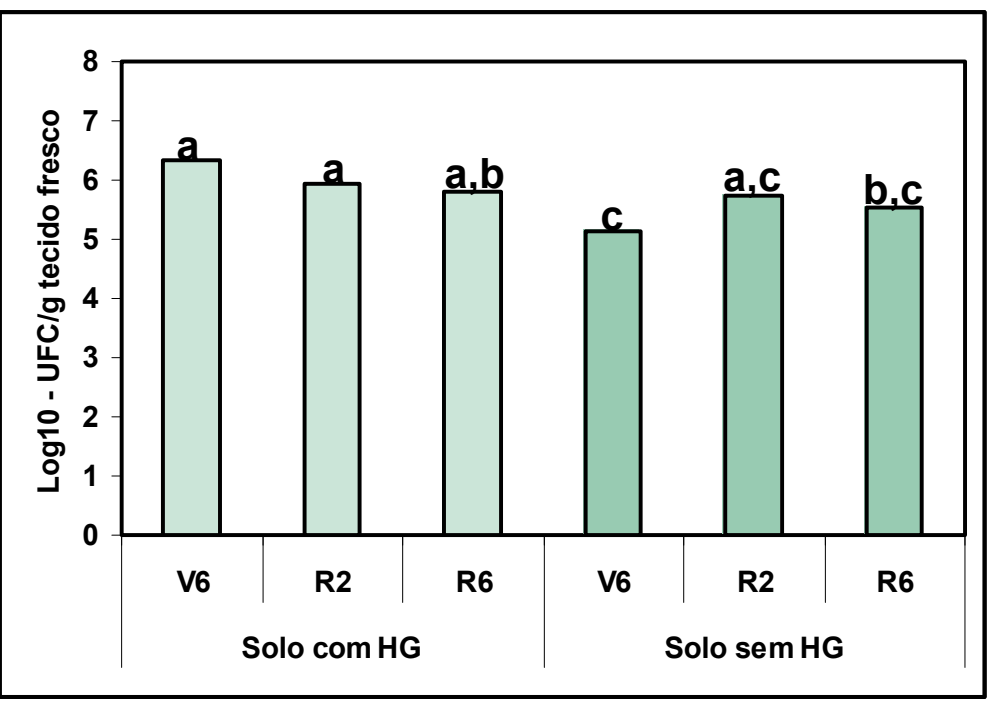

Figura 3 - Densidade populacional total da comunidade bacteriana epifítica de soja durante as fases: V6; R2 e R6, em solo com e sem aplicação em pré-plantio do herbicida glifosato (HG). Médias com a mesma letra não são significativamente diferentes pelo teste de Tukey $(P$ $>0.01)$

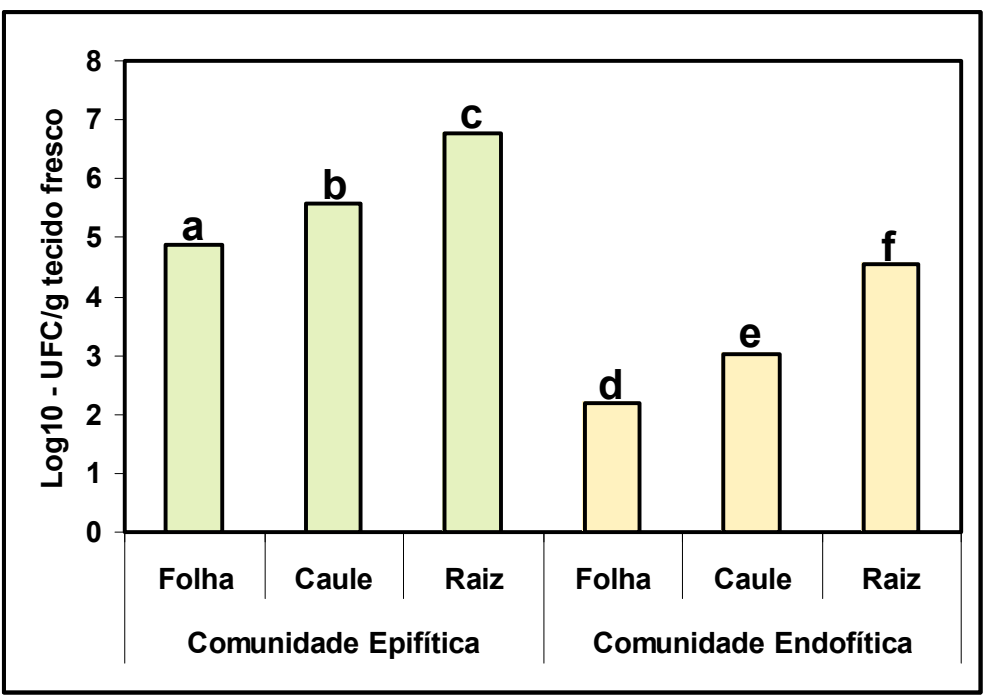

Figura 4 - Densidade populacional total da comunidade bacteriana epifítica e endofítica de soja nos tecidos avaliados (Folha, Caule e Raiz). Médias com a mesma letra não são significativamente diferentes pelo teste de Tukey $(P>0.01)$ 


\subsubsection{Isolamento, identificação e análise filogenética de bactérias endofíticas e epifíticas de soja}

Durante os experimentos de isolamento, foram coletados diferentes grupos morfológicos de forma aleatória, resultando em 361 isolados bacterianos epifíticos e 373 isolados endofíticos de folha, caule e raiz de plantas das cultivares Foscarin e Cristalina crescidas em solo com e sem aplicação em préplantio do herbicida glifosato, durante três estádios de desenvolvimento do hospedeiro (V6, R2 e R6), nas safras 2000/01 e 2001/02.

Nas condições utilizadas, foram observados pelo menos 12 morfogrupos de bactérias endofíticas e epifíticas (Tabela 1, Figura 5). Além da classificação morfológica, foi utilizada a técnica de ARDRA para agrupar os isolados. Após amplificação e clivagem do $16 \mathrm{~S}$ rDNA de 170 isolados bacterianos (110 endofíticos e 60 epifíticos) foi possível a observação de 11 padrões de ARDRA (ou haplótipos). Estes haplótipos não corresponderam aos grupos morfológicos, ou seja, diferentes haplótipos representaram um único morfogrupo e vice-versa, sendo por este motivo utilizado somente o agrupamento via ARDRA (nomeados $\mathrm{G} 1$ a G11) para futuras análises.

Isolados representativos de todos os haplótipos observados foram identificados por meio da seqüência parcial do $16 \mathrm{~S}$ rDNA ou por análise de FAME (ácidos graxos) e BIOLOG. Desta forma, aproximadamente $25 \%$ dos isolados bacterianos totais foram identificados, sendo que isolados com o mesmo haplótipo foram considerados pertencentes ao mesmo gênero e espécie. A Tabela 2 apresenta os resultados da identificação e revela que a comunidade bacteriana associada à soja é composta basicamente pelo grupo taxonômico Proteobacteria, sendo representado pelos subgrupos alfa $(\alpha)$, beta ( $\beta$ ) e gama $(\gamma)$. 
Tabela 1. Descrição das características morfológicas dos grupos bacterianos endofíticos e epifíticos isolados de soja

\begin{tabular}{|c|c|}
\hline Grupos & Características Morfológicas \\
\hline A & $\begin{array}{l}\text { Colônias de tamanho variado, com aspecto liso e cremoso, com borda } \\
\text { regular e de coloração amarela. }\end{array}$ \\
\hline B & $\begin{array}{l}\text { Colônias de tamanho variado, com aspecto liso e translúcido, com } \\
\text { borda regular e de coloração amarela. }\end{array}$ \\
\hline C & $\begin{array}{l}\text { Colônias de tamanho variado, com aspecto liso e cremoso, com borda } \\
\text { irregular e de coloração amarela, algumas com halo da mesma cor } \\
\text { difundindo em torno da colônia. }\end{array}$ \\
\hline $\mathbf{D}$ & $\begin{array}{l}\text { Colônias de tamanho variado, com aspecto liso e cremoso, com borda } \\
\text { regular e de coloração branca. }\end{array}$ \\
\hline $\mathbf{E}$ & $\begin{array}{l}\text { Colônias de tamanho variado, com aspecto liso e translúcido, com } \\
\text { borda regular e de coloração branca. }\end{array}$ \\
\hline $\mathbf{F}$ & $\begin{array}{l}\text { Colônias de tamanho variado, com aspecto liso e cremoso, com borda } \\
\text { irregular e de coloração branca, algumas com halo da mesma cor } \\
\text { difundindo em torno da colônia. }\end{array}$ \\
\hline G & $\begin{array}{l}\text { Colônias de tamanho variado, com aspecto liso e cremoso, com borda } \\
\text { regular e de coloração bege. }\end{array}$ \\
\hline $\mathbf{H}$ & $\begin{array}{l}\text { Colônias de tamanho variado, com aspecto liso e cremoso, com borda } \\
\text { irregular e de coloração amarela, com produção e difusão de pigmento } \\
\text { da mesma cor em torno da colônia. }\end{array}$ \\
\hline I & $\begin{array}{l}\text { Colônias de tamanho variado, com aspecto liso e cremoso, com borda } \\
\text { regular e de coloração rosa. }\end{array}$ \\
\hline $\mathbf{J}$ & $\begin{array}{l}\text { Colônias de tamanho variado, com aspecto liso e cremoso, com borda } \\
\text { regular e de coloração laranja. }\end{array}$ \\
\hline $\mathbf{K}$ & Colônias pequenas, de aspecto liso e incolores. \\
\hline $\mathbf{L}$ & $\begin{array}{l}\text { Bactérias diferentes das pertencentes aos grupos } \mathrm{A} \text { a } \mathrm{K} \text {, sendo pouco } \\
\text { freqüentes. }\end{array}$ \\
\hline
\end{tabular}



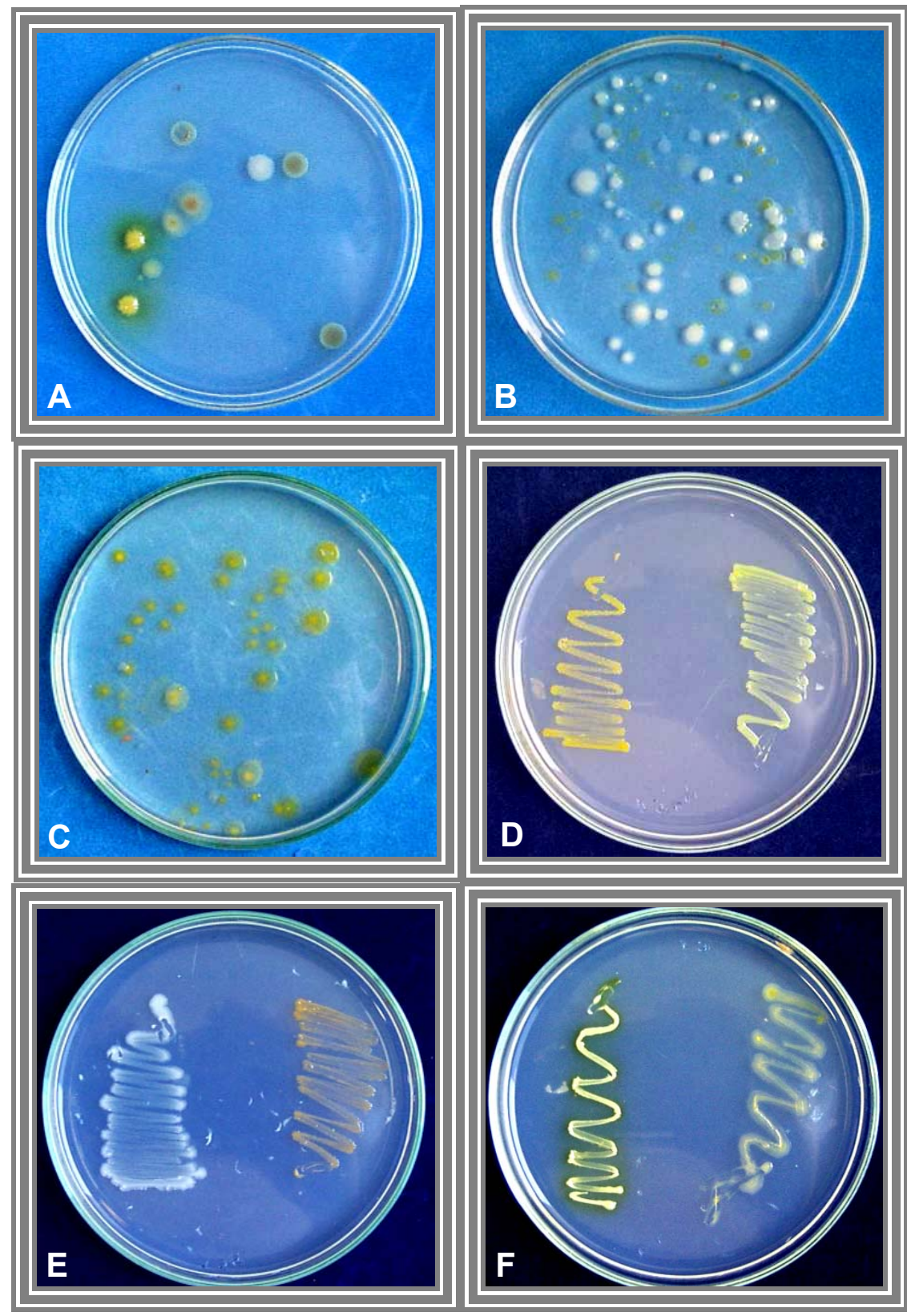

Figura 5 - Aspectos morfológicos de bactérias associadas à soja. A, B, C) Placas de Petri do isolamento total de bactérias endofíticas e epifíticas de soja; D, E, F) Placas de Petri da purificação de alguns grupos bacterianos 
Tabela 2. Identificação e distribuição taxonômica dos grupos bacterianos isolados de soja (agrupados por ARDRA)

\begin{tabular}{ccl}
\hline Grupo & Filiação Taxonômica & Espécies \\
\hline G1 & $\beta$-Proteobacteria & $\begin{array}{l}\text { Ralstonia picketti } \\
\text { Pseudomonas sp., P. oryzihabitans e } \\
\text { P2 citronellolis }\end{array}$ \\
G3 & $\gamma$-Proteobacteria & $\begin{array}{l}\text { Enterobacter agglomerans e } \\
\text { Enterobacteriaceae }\end{array}$ \\
G4 & $\beta$-Proteobacteria & Burkholderia sp. \\
G5 & $\gamma$-Proteobacteria & Pseudomonas sp., P. straminea e P. fulva \\
G6 & $\beta$-Proteobacteria & $\begin{array}{l}\text { Ralstonia picketti } \\
\text { Klebsiella pneumoniae, K. oxytoca, }\end{array}$ \\
G7 & $\gamma$-Proteobacteria & Erwinia sp., e Enterobacteriaceae \\
G8 & $\gamma$-Proteobacteria & Acinetobacter sp. e A. calcoaceticus \\
G9 & $\gamma$-Proteobacteria & Enterobacter sakazaki \\
G10 & $\gamma$-Proteobacteria & Pseudomonas sp. \\
G11 & $\alpha$-Proteobacteria & Agrobacterium sp. e \\
& Caulobacter/Asticcacaulis \\
\hline
\end{tabular}

A subdivisão $\gamma$-Proteobacteria foi a mais numerosa, tanto em populações endofíticas quanto epifíticas. Dentro desta subdivisão, Enterobacteriaceae foi o grupo mais freqüente e que apresentou maior diversidade de gêneros (G3, G7 e G9), sendo seguido pelo grupo Pseudomonadaceae (G2, G5 e G10) em relação à freqüência relativa (Tabela $3)$.

Tabela 3. Freqüência relativa (\%) dos grupos bacterianos em relação a microbiota endofítica (EN) e epifítica (EP) de soja

\begin{tabular}{ccccccccccccc}
\hline & G1 & G2 & G3 & G4 & G5 & G6 & G7 & G8 & G9 & G10 & G11 & Total $^{*}$ \\
\hline EN & 2,73 & 25,45 & 12,73 & 5,45 & 5,45 & 0,91 & 39,09 & 0,91 & 1,82 & 1,82 & 3,64 & 110 \\
EP & 1,67 & 21,67 & 13,33 & 3,33 & 1,67 & 0 & 48,33 & 3,33 & 1,67 & 1,67 & 3,33 & 60 \\
\hline
\end{tabular}

*Total de isolados avaliados. 
A freqüência relativa dos grupos bacterianos em relação ao tratamento do solo com aplicação em pré-plantio do herbicida glifosato, cultivar, fase de desenvolvimento e tecido vegetal foram avaliados. Foi possível observar maior diversidade de espécies em plantas cultivadas após a aplicação de glifosato. Entretanto, para a comunidade epifítica este fato não foi observado (Tabela 4). Ainda neste aspecto, é interessante salientar que a população epifítica do grupo G3 (Enterobacteriaceae) foi maior em plantas cultivadas em solo sem aplicação do que com aplicação do herbicida (Tabela 4), enquanto os grupos G6 ( $E$. sakazaki) e G9 (R. pickettii) foram isolados somente de plantas cultivadas em solo sem e com aplicação do herbicida, respectivamente.

Em relação a cultivar de soja, a Tabela 5 mostra que a diversidade de bactérias endofíticas e epifíticas foi maior na cultivar Foscarin (ciclo precoce), sendo observado que os grupos G6 ( $R$. picketti) e G9 (E. sakazaki) foram isolados somente desta cultivar. Entretanto, o grupo G7 (Enterobacteriaceae), que foi isolado das duas cultivares, apresentou maior freqüência na cultivar Cristalina.

A microbiota endofítica apresentou um perfil crescente de grupos bacterianos em relação às fases de desenvolvimento do hospedeiro, das quais foram isoladas, ou seja, V6 $<R 2<R 6$ em número de grupos. Entretanto, as bactérias epifíticas isoladas de plantas em fase R2 apresentaram maior número de grupos em relação às outras fases (Tabela 6). Foi observado também que o grupo G2 (Pseudomonadaceae) foi mais freqüente na fase R6, enquanto o grupo G7 (Enterobacteriaceae) foi o mais numeroso na comunidade epifítica na fase V6. O grupo G5 (Pseudomonadaceae) não foi observado na fase V6, enquanto o grupo G9 (E. sakazaki) foi específico para a fase V2 (Tabela 6). 
Tabela 4. Freqüência relativa (\%) dos grupos bacterianos em relação a microbiota endofítica (EN) e epifítica (EP) de plantas de soja cultivadas em solo com e sem aplicação pré-plantio do herbicida glifosato

\begin{tabular}{ccccc}
\hline \multirow{2}{*}{ Grupos } & \multicolumn{2}{c}{ Solo com Glifosato } & \multicolumn{2}{c}{ Solo sem Glifosato } \\
\cline { 2 - 5 } & EN & \multicolumn{1}{c}{ EP } & \multicolumn{1}{c}{ EN } & \multicolumn{1}{c}{ EP } \\
\hline G1 & 3,08 & 3,45 & 2,22 & 0 \\
G2 & 24,61 & 24,13 & 26,67 & 19,35 \\
G3 & 10,77 & 6,90 & 15,56 & 19,35 \\
G4 & 4,61 & 0 & 6,67 & 6,45 \\
G5 & 6,15 & 0 & 4,44 & 3,23 \\
G6 & 0 & 0 & 2,22 & 0 \\
G7 & 38,47 & 51,72 & 40,00 & 45,16 \\
G8 & 1,54 & 3,45 & 0 & 3,23 \\
G9 & 3,08 & 3,45 & 0 & 0 \\
G10 & 1,54 & 3,45 & 2,22 & 0 \\
G11 & 6,15 & 3,45 & 0 & 3,23 \\
Total $^{*}$ & $\mathbf{6 5}$ & $\mathbf{2 9}$ & $\mathbf{4 5}$ & $\mathbf{3 1}$ \\
\hline
\end{tabular}

${ }^{*}$ Total de isolados avaliados.

Tabela 5. Freqüência relativa (\%) dos grupos bacterianos em relação a microbiota endofítica (EN) e epifítica (EP) de plantas de soja das cultivares Foscarin e Cristalina

\begin{tabular}{crrrr}
\hline \multirow{2}{*}{ Grupos } & \multicolumn{2}{c}{ Foscarin } & \multicolumn{2}{c}{ Cristalina } \\
\cline { 2 - 5 } & \multicolumn{1}{c}{ EN } & \multicolumn{1}{c}{ EP } & \multicolumn{1}{c}{ EN } & \multicolumn{1}{c}{ EP } \\
\hline G1 & 6,67 & 0 & 0 & 3,84 \\
G2 & 26,67 & 23,54 & 24,61 & 19,23 \\
G3 & 11,11 & 14,70 & 13,85 & 11,54 \\
G4 & 2,22 & 5,88 & 7,69 & 0 \\
G5 & 4,44 & 2,94 & 6,15 & 0 \\
G6 & 2,22 & 0 & 0 & 0 \\
G7 & 35,57 & 41,18 & 41,54 & 57,69 \\
G8 & 0 & 2,94 & 1,54 & 3,85 \\
G9 & 4,44 & 2,94 & 0 & 0 \\
G10 & 2,22 & 2,94 & 1,54 & 0 \\
G11 & 4,44 & 2,94 & 3,08 & 3,85 \\
Total $^{*}$ & $\mathbf{4 5}$ & $\mathbf{3 4}$ & $\mathbf{6 5}$ & $\mathbf{2 6}$ \\
\hline
\end{tabular}

${ }^{*}$ Total de isolados analisados. 
Tabela 6. Freqüência relativa (\%) dos grupos bacterianos em relação a microbiota endofítica (EN) e epifítica (EP) de plantas de soja durante os estádios de desenvolvimento vegetal V6, R2 e R6

\begin{tabular}{crrrrrr}
\hline \multirow{2}{*}{ Grupos } & \multicolumn{2}{c}{ V6 } & \multicolumn{2}{c}{ R2 } & \multicolumn{2}{c}{ R6 } \\
\cline { 2 - 7 } & \multicolumn{1}{c}{ EN } & \multicolumn{1}{c}{ EP } & \multicolumn{1}{c}{ EN } & EP & EN & EP \\
\hline G1 & 3,33 & 6,25 & 4,08 & 0 & 0 & 0 \\
G2 & 30,00 & 12,50 & 16,33 & 17,24 & 35,49 & 40,00 \\
G3 & 13,33 & 0 & 14,28 & 20,69 & 9,69 & 13,33 \\
G4 & 10,00 & 0 & 4,08 & 6,89 & 3,22 & 0 \\
G5 & 0 & 0 & 6,12 & 3,45 & 9,69 & 0 \\
G6 & 0 & 0 & 0 & 0 & 3,22 & 0 \\
G7 & 33,33 & 75,00 & 48,99 & 37,93 & 29,03 & 40,00 \\
G8 & 0 & 6,25 & 0 & 3,45 & 3,22 & 0 \\
G9 & 0 & 0 & 4,08 & 3,45 & 0 & 0 \\
G10 & 3,33 & 0 & 0 & 3,45 & 3,22 & 0 \\
G11 & 6,68 & 0 & 2,04 & 3,45 & 3,22 & 6,67 \\
Total $^{*}$ & $\mathbf{3 0}$ & $\mathbf{1 6}$ & $\mathbf{4 9}$ & $\mathbf{2 9}$ & $\mathbf{3 1}$ & $\mathbf{1 5}$ \\
\hline
\end{tabular}

${ }^{*}$ Total de isolados analisados.

No presente trabalho, foram avaliados folhas, caules e raízes de soja, sendo possível observar que a microbiota endofítica da raiz apresentou maior diversidade de grupos do que a da folha e a do caule. Entretanto, a microbiota epifítica não apresentou diferença no número de grupos em folha, caule ou raiz, mas revelou a presença de grupos específicos em relação ao tecido (Tabela 7). Além disso, foi observado que os grupos representantes de $\beta$-Proteobacteria (G1, G4 e G6 - Burkholdeeriaceae) foram isolados apenas de raiz, enquanto o grupo G8 (Moraxellaceae) somente de caule. 
Tabela 7. Freqüência relativa (\%) dos grupos bacterianos em relação a microbiota endofítica (EN) e epifítica (EP) isoladas de folha, caule e raiz de plantas de soja

\begin{tabular}{crrrrrr}
\hline \multirow{2}{*}{ Grupos } & \multicolumn{2}{c}{ Folha } & \multicolumn{2}{c}{ Caule } & \multicolumn{2}{c}{ Raiz } \\
\cline { 2 - 7 } & \multicolumn{1}{c}{ EN } & EP & \multicolumn{1}{c}{ EN } & EP & EN & EP \\
\hline G1 & 0 & 0 & 0 & 0 & 8,33 & 5,00 \\
G2 & 36,59 & 26,08 & 27,27 & 17,65 & 11,11 & 20,00 \\
G3 & 21,95 & 13,04 & 12,12 & 29,41 & 2,78 & 0 \\
G4 & 0 & 0 & 0 & 0 & 16,67 & 10,00 \\
G5 & 2,44 & 4,35 & 9,10 & 0 & 5,55 & 0 \\
G6 & 0 & 0 & 0 & 0 & 2,78 & 0 \\
G7 & 31,70 & 47,83 & 45,45 & 35,30 & 41,67 & 60,00 \\
G8 & 0 & 0 & 3,03 & 11,76 & 0 & 0 \\
G9 & 0 & 4,35 & 3,03 & 0 & 2,78 & 0 \\
G10 & 2,44 & 4,35 & 0 & 0 & 2,78 & 0 \\
G11 & 4,88 & 0 & 0 & 5,88 & 5,55 & 5,00 \\
Total $^{*}$ & $\mathbf{4 1}$ & $\mathbf{2 3}$ & $\mathbf{3 3}$ & $\mathbf{1 7}$ & $\mathbf{3 6}$ & $\mathbf{2 0}$ \\
\hline
\end{tabular}

${ }^{*}$ Total de isolados analisados.

As relações filogenéticas entre bactérias endofíticas e epifíticas foram obtidas por meio da análise da seqüência parcial do gene que codifica a subunidade $16 S$ do RNA ribossômico (16S rDNA). Foram obtidas seqüências de 25 isolados endofíticos e 26 epifíticos; estas seqüências foram alinhadas e analisadas pelo BLASTn e programa ARB, sendo construídas árvores filogenéticas (Figuras 5 a 10).

As árvores filogenéticas agruparam os isolados nas famílias Rhizobiaceae, Caulobacteriaceae, Burkholderiaceae, Moraxellaceae, Pseudomonadaceae e Enterobacteriaceae. Destas, a família Enterobacteriaceae foi a que apresentou maior diversidade (Figuras 9 e 10), seguida de Pseudomonadaceae (Figura 8). Não foi possível observar agrupamentos de acordo com a origem (endofíticos ou epifíticos), sendo observada alta similaridade entre isolados de diferentes origens, como os isolados EN251 e EP55 (Figura 7), EN315 e EP122 (Figura 8), EN141 e EP108 (Figura 9A) ou EN108 e EP203 (Figura 10B). 
Além disso, a análise filogenética permitiu a identificação de muitos isolados ao nível de espécie, enquanto outros apenas ao nível de gênero e muitos isolados pertencentes à família Enterobacteriaceae só foram passíveis de classificação ao nível de família.

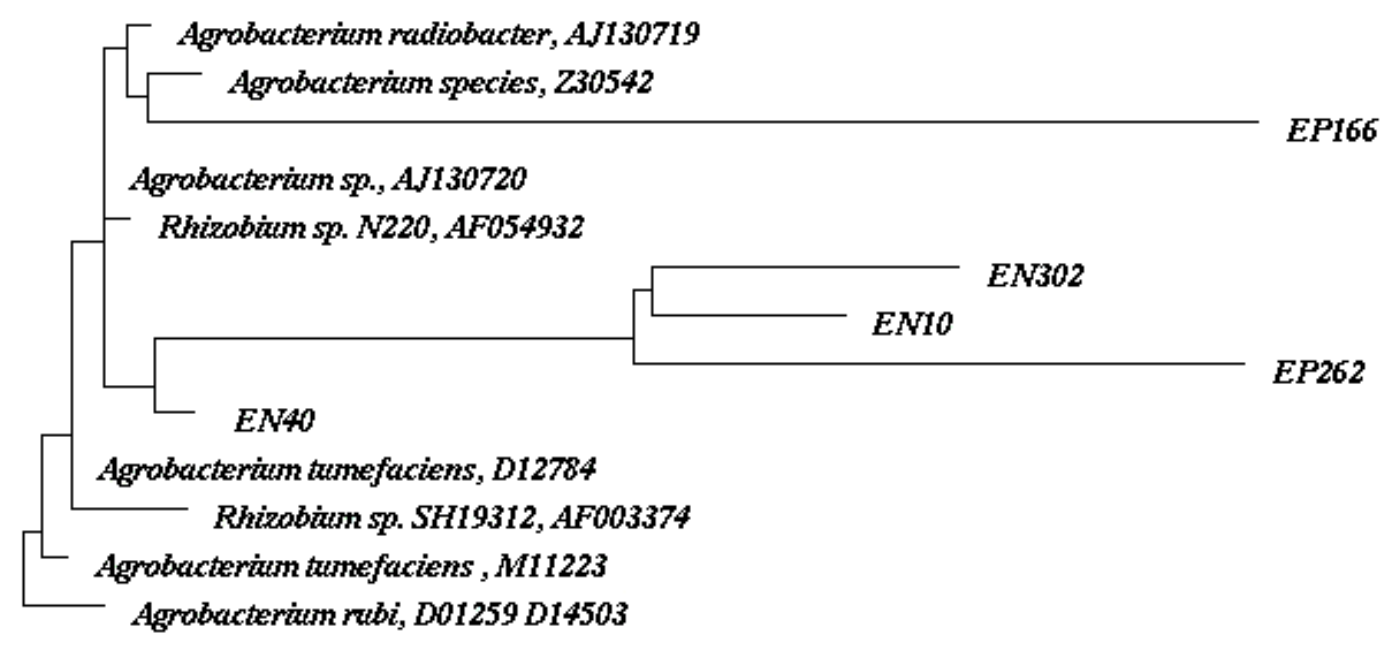

A $\quad 0.10$

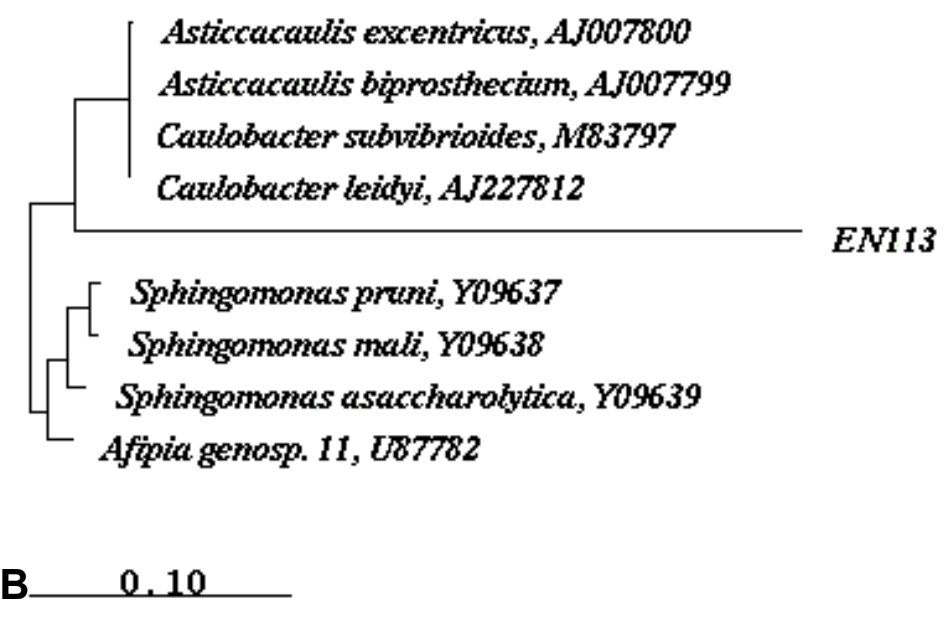

Figura 6 - Subdivisão $\alpha$-Proteobacteria, Família Rhizobiaceae (A) e Caulobacteriaceae (B). Árvores filogenéticas construídas pelo programa ARB a partir de seqüências do $16 \mathrm{~S}$ rDNA de bactérias endofíticas (EN) e epifíticas (EP) 


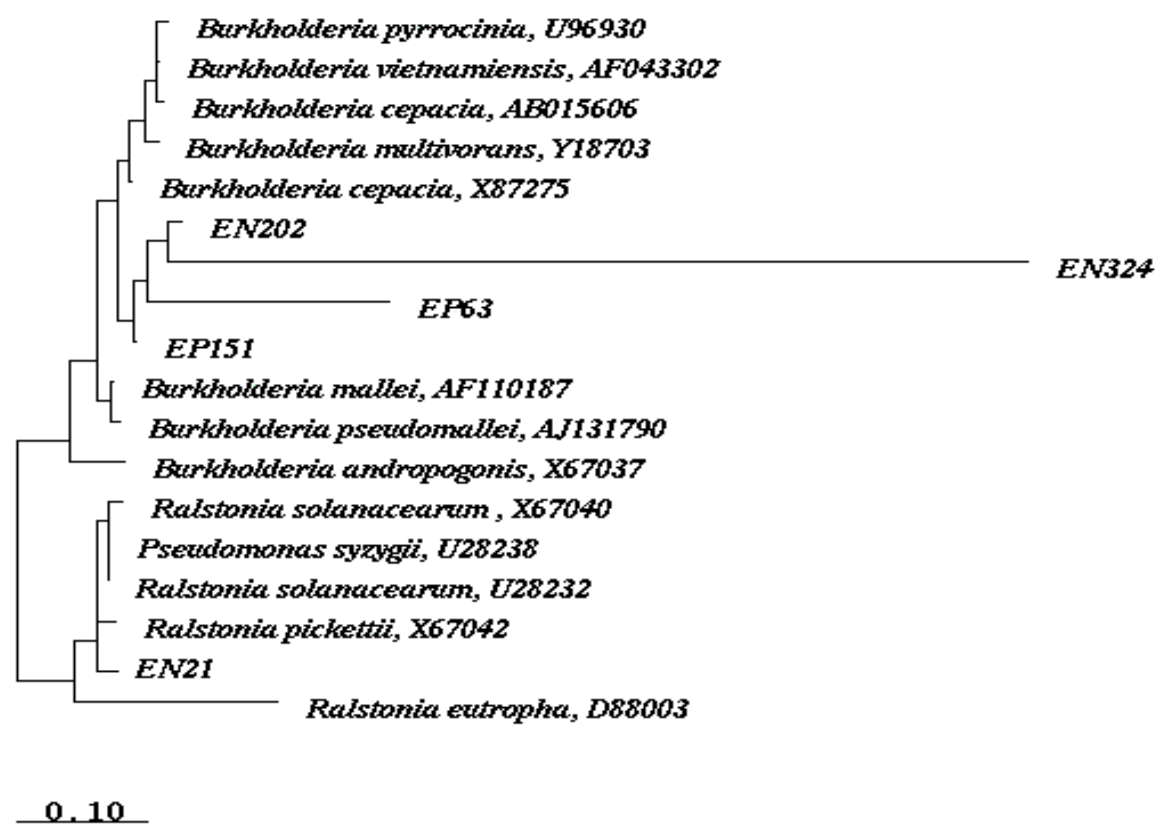

Figura 7 - Subdivisão $\beta$-Proteobacteria, Família Burkholderiaceae. Árvores filogenéticas construídas pelo programa ARB a partir de seqüências do 16S rDNA de bactérias endofíticas (EN) e epifíticas (EP)

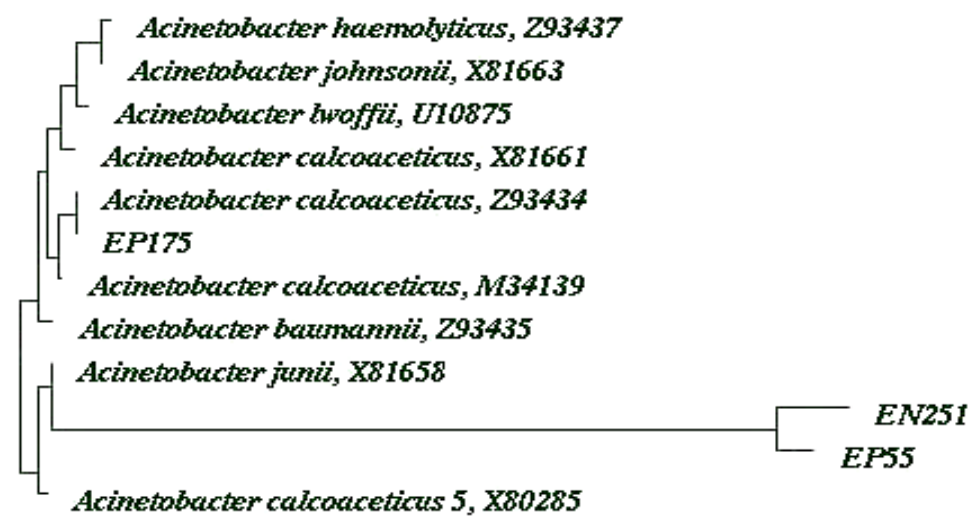

0. 10

Figura 8 - Subdivisão $\gamma$-Proteobacteria, Família Moraxellaceae. Árvore filogenética construída pelo programa ARB a partir de seqüências do 16S rDNA de bactérias endofíticas (EN) e epifíticas (EP) 


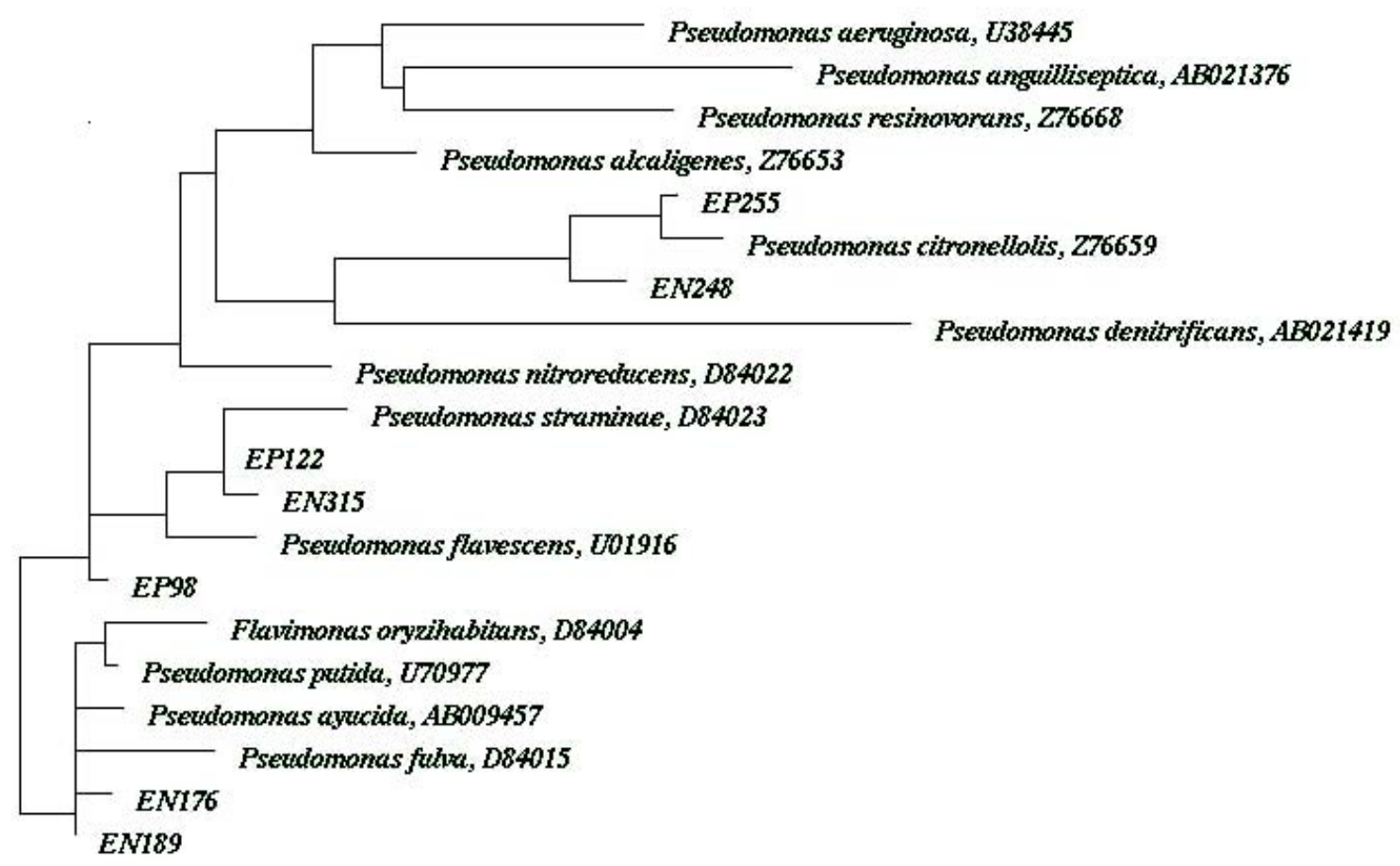

0.10

Figura 9 - Subdivisão $\gamma$-Proteobacteria, Família Pseudomonadaceae. Árvore filogenética construída pelo programa $A R B$ a partir de seqüências do $16 \mathrm{~S}$ rDNA de bactérias endofíticas (EN) e epifíticas (EP) 


\section{Escherichia coli 9, U70214}

Shigella dysenteriae, X96966

\section{ENI41}

EP108

Enterobacter sakazakï, $A B 004746$

Edwardsiella tanda, AF015259

A

0.10

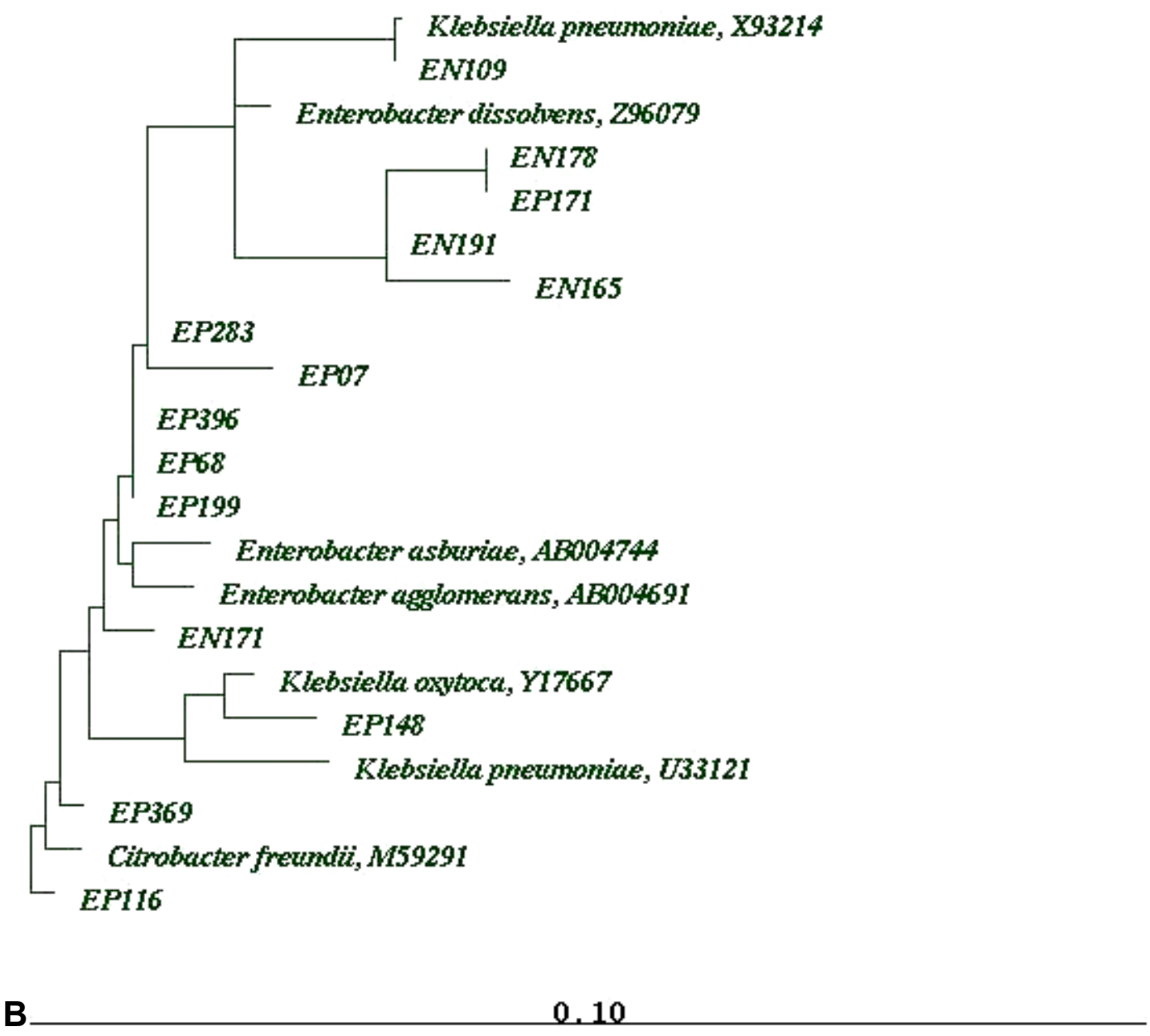

Figura 10 - Subdivisão $\gamma$-Proteobacteria, Família Enterobacteriaceae (A,B). Árvores filogenéticas construídas pelo programa ARB a partir de seqüências do 16S rDNA de bactérias endofíticas (EN) e epifíticas (EP) 
A 0.10

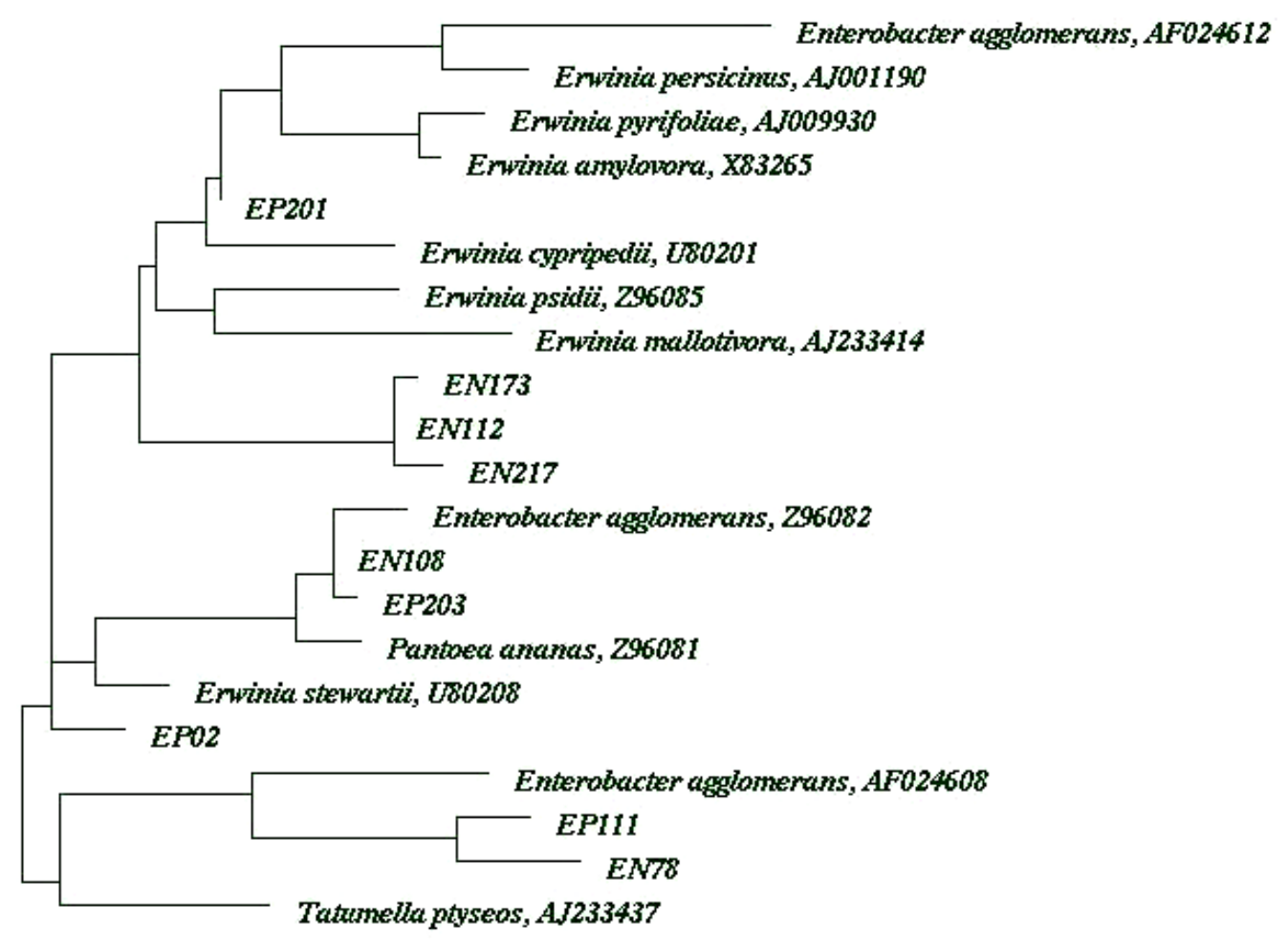

B 0.10

Figura 11 - Subdivisão $\gamma$-Proteobacteria, Família Enterobacteriaceae $(\mathbf{A}, \mathbf{B})$. Árvores filogenéticas construídas pelo programa ARB a partir de seqüências do 16S rDNA de bactérias endofíticas (EN) e epifíticas (EP) 


\subsubsection{Análise de DGGE da comunidade bacteriana endofítica de soja}

A análise de DGGE da comunidade bacteriana endofítica foi realizada em amostras de raízes das cultivares Foscarin e Cristalina nos estádios de desenvolvimento vegetal V6 e R2, cultivadas em solo com e sem aplicação em pré-plantio do herbicida glifosato.

O padrão de DGGE dos produtos de PCR (utilizando primers universais para a região 968-1387 do 16S rDNA) de DNA total extraído de raízes revelou que durante a fase V6 (vegetativa) houve clara diferença entre a microbiota bacteriana das plantas cultivadas em solo com aplicação de glifosato e as de solo sem aplicação (Figura 11). Foi observada a presença de bandas (bandas 1 e 4) para as amostras provenientes de plantas cultivadas em solo com glifosato (pré-plantio) e para as plantas cultivadas em solo sem glifosato (bandas 3, 6 e 7) (Figura 11 e Tabela 8). Contudo, não houve diferença relevante em relação ao genótipo do hospedeiro.

Quando analisado o padrão de DGGE das amostras de plantas na fase R2 (florescimento) (Figura 12), foi observada maior heterogeneidade em relação ao padrão da fase V6. Nesta fase também não foi observada diferença relevante entre as cultivares de soja, mas foi possível detectar bandas específicas em tratamentos com glifosato (bandas 8 e 10) (Figura 12). Além disso, a banda 9 (Agrobacterium sp. - Tabela 8) esteve presente na maioria das amostras.

A análise das bandas de DGGE permitiu verificar que a maioria dos grupos bacterianos observados nas amostras avaliadas pertence à subdivisão $\gamma$-Proteobacteria (Tabela 8). A identificação das bandas dos géis de DGGE permitiu a observação de grupos bacterianos previamente isolados e cultivados durante os experimentos de isolamento, tais como Pseudomonas sp., Pantoea sp., Enterobacter sp., Erwinia sp. e Agrobacterium sp. Entretanto, Stenotrophomonas maltophilia (banda 19), Xanthomonas sp. (banda 16) e Herbaspirillum sp. (banda 13) foram encontrados apenas por reamplificação das 
bandas de DGGE (Figura 12 e Tabela 8). É interessante ressaltar que Stenotrophomonas maltophilia e Xanthomonas sp. foram observados apenas nos tratamentos sem aplicação de glifosato. O inverso é observado com Herbaspirillum sp., visto que esta bactéria foi detectada apenas em plantas cultivadas em solo com aplicação em pré-plantio do herbicida glifosato. 


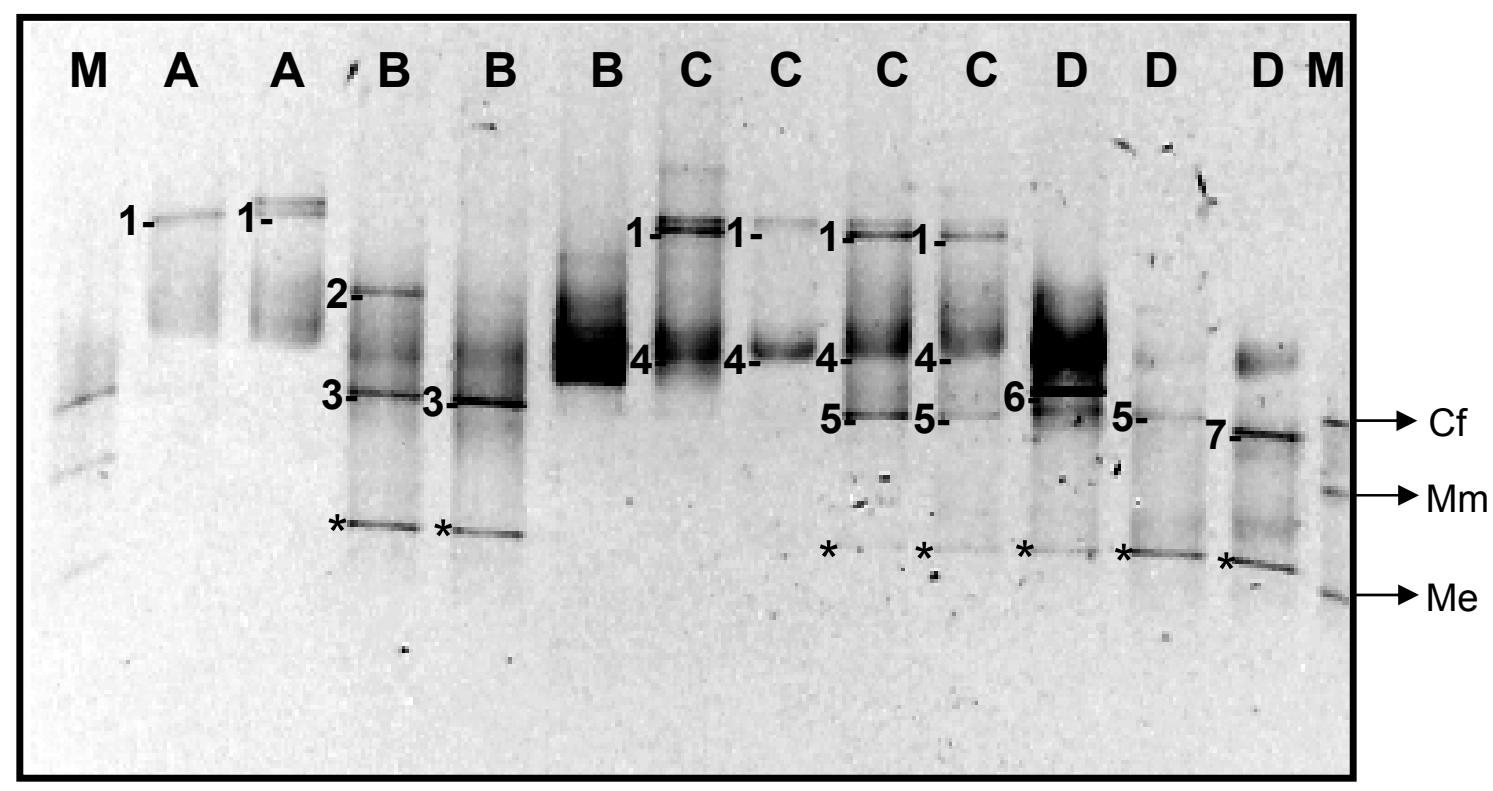

*Cloroplasto

Figura 12 - Caracterização da comunidade bacteriana endofítica de raízes de soja na fase V6 por DGGE. M) Marcador obtido com a amplificação do fragmento 968-1387 do 16S rDNA de culturas puras de Curtobacterium flaccufaciens (Cf), Methylobacterium mesophilicum $(\mathrm{Mm})$ e $M$. extorquens (Me); A) DNA total da cultivar Foscarin cultivada em solo com aplicação de glifosato; B) DNA total da cultivar Foscarin cultivada em solo sem aplicação de glifosato; C) DNA total da cultivar Cristalina cultivada em solo com aplicação de glifosato; D) DNA total da cultivar Cristalina cultivada em solo sem aplicação de glifosato 


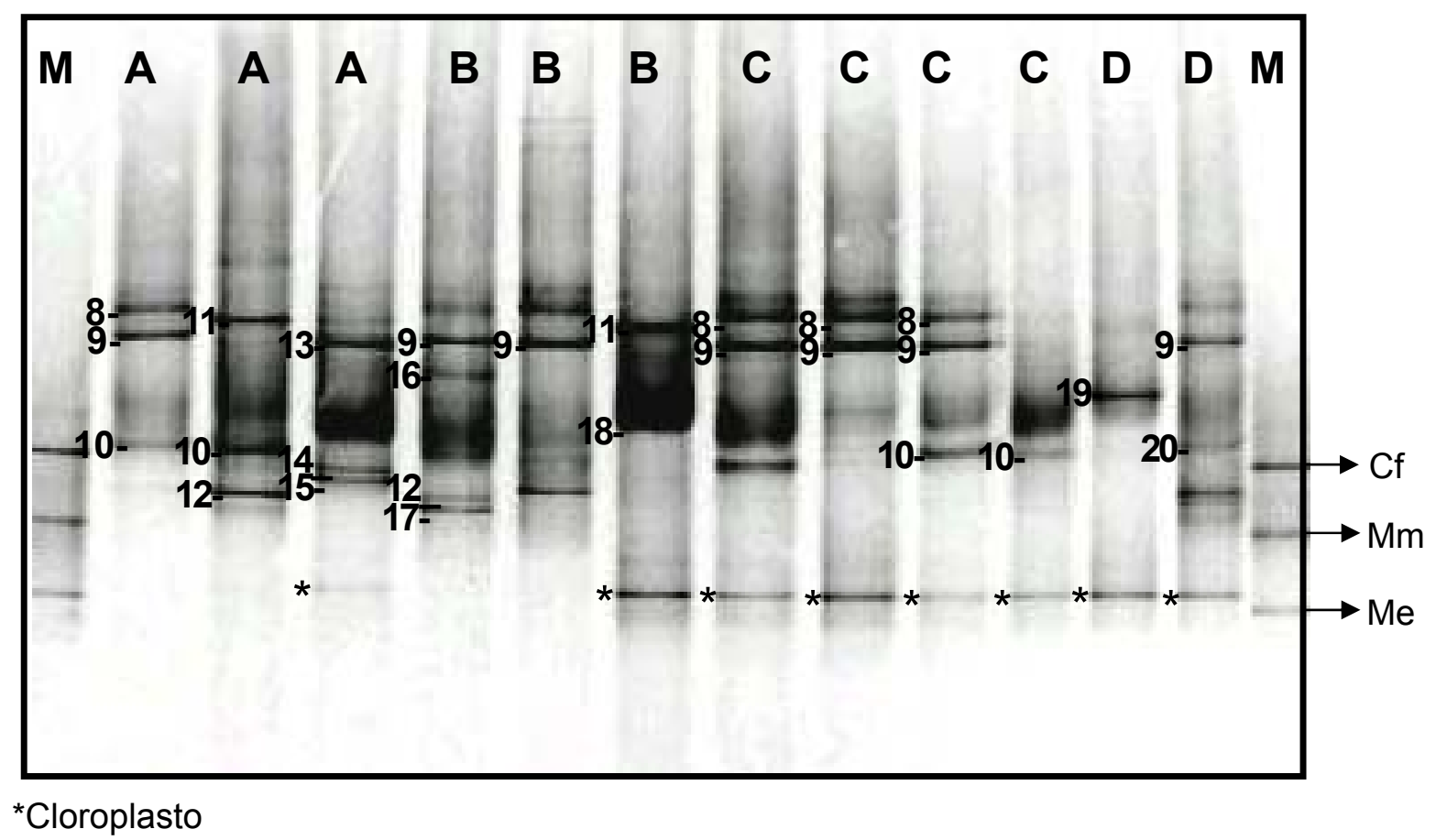

Figura 13 - Caracterização da comunidade bacteriana endofítica de raízes de soja na fase R2 por DGGE. M) Marcador obtido com a amplificação do fragmento 968-1387 do 16S rDNA de culturas puras de $C$. flaccufaciens (Cf), M. mesophilicum (Mm) e M. extorquens (Me); A) DNA total da cultivar Foscarin cultivada em solo com aplicação de glifosato; B) DNA total da cultivar Foscarin cultivada em solo sem aplicação de glifosato; C) DNA total da cultivar Cristalina cultivada em solo com aplicação de glifosato; D) DNA total da cultivar Cristalina cultivada em solo sem aplicação de glifosato 
Tabela 8. Identificação das bandas reamplificadas das amostras de DGGE de raiz de soja nas fases V6 (bandas 1 a 7 ) e R2 (bandas 8 a 20)

\begin{tabular}{cccc}
\hline Banda & Identificação & \% Similaridade & Grupo \\
\hline 1 & Pantoea sp. & 100 & $\gamma$-Proteobacteria \\
2 & Enterobacter sp. & 98 & $\gamma$-Proteobacteria \\
3 & Bradyrhizobium sp. & 87 & $\alpha$-Proteobacteria \\
4 & Pseudomonas sp. & 97 & $\gamma$-Proteobacteria \\
5 & Pseudomonas sp. & 99 & $\gamma$-Proteobacteria \\
6 & Pantoea sp. & 89 & $\gamma$-Proteobacteria \\
7 & Bradyrhizoubium japonicum & 98 & $\alpha$-Proteobacteria \\
8 & Agrobacterium sp. & 90 & $\alpha$-Proteobacteria \\
9 & Agrobacterium sp. & 80 & $\alpha$-Proteobacteria \\
10 & Pseudomonas sp. & 82 & $\gamma$-Proteobacteria \\
11 & Pantoea sp. & 99 & $\gamma$-Proteobacteria \\
12 & Pseudomonas putida & 99 & $\gamma$-Proteobacteria \\
13 & Herbaspirillum sp. & 98 & $\beta$-Proteobacteria \\
14 & Erwinia sp. & 97 & $\gamma$-Proteobacteria \\
15 & Erwinia sp. & 97 & $\gamma$-Proteobacteria \\
16 & Xanthomonas sp. & 93 & $\gamma$-Proteobacteria \\
17 & Pseudomonas putida & 99 & $\gamma$-Proteobacteria \\
18 & Pantoea sp. & 99 & $\gamma$-Proteobacteria \\
19 & Stenotrophomonas malthophilia & 100 & $\gamma$-Proteobacteria \\
20 & Pantoea sp. & 89 & $\gamma$-Proteobacteria \\
\hline
\end{tabular}

\subsection{Discussão}

A ecologia microbiana envolve tanto o estudo da estrutura quanto o da função de cada grupo microbiano em um ecossistema. Avaliações representativas de comunidades microbianas não só devem considerar a abundância e distribuição de espécies mas também a diversidade funcional e redundância presente em uma comunidade microbiana. Neste contexto, o habitat associado à planta é um ambiente dinâmico no qual muitos fatores, tais como, mudanças sazonais, tecidos vegetais (Mocali et al., 2003), cultivares e espécies de plantas, tipos de solo (Dalmastri et al., 1999; Fromin et al., 2001) e interação com outros microrganismos benéficos ou patogênicos (Araújo et al., 
2001; Araújo et al., 2002), podem afetar a estrutura e composição de espécies das comunidades bacterianas que colonizam os tecidos das plantas. $O$ conhecimento da estrutura e composição de espécies que compõem comunidades bacterianas associadas às plantas é fundamental para o entendimento de como os processos biológicos associados às plantas podem ser influenciados por meio de fatores ambientais e, por conseqüência, terem aplicações biotecnológicas.

A maioria dos estudos com bactérias associadas à soja está freqüentemente relacionada ao sistema de nodulação e interação com Bradyrhizobium (Polenko et al., 1987; Oehrle et al., 2000; Bai et al., 2002) ou na relação com fitopatógenos (Kloepper et al., 1991; Volksch et al., 1992; May et al., 1997). Portanto, o presente estudo é um dos primeiros trabalhos que explora várias condições ambientais e fisiológicas na interação bactérias-soja, não considerando o sistema de nodulação.

Entre os fatores analisados no presente estudo, variações sazonais, tratamentos do solo e cultivares do hospedeiro apresentaram pouca ou nenhuma influência sobre a densidade populacional das comunidades bacterianas endofíticas e epifíticas, mas foi observado que estes fatores apresentaram influência sobre a diversidade de grupos bacterianos. Isto sugere que pode ter ocorrido mudanças nas densidades populacionais de diferentes grupos sem alteração da densidade total. Entretanto, os estádios de desenvolvimento do hospedeiro e os tecidos vegetais influenciaram tanto a densidade populacional quanto à diversidade das populações bacterianas analisadas, sugerindo que o tecido e a fase fisiológica do hospedeiro estejam relacionadas com a capacidade de colonização e estabelecimento de grupos bacterianos específicos. Neste aspecto, pode-se sugerir que ocorra sucessão de espécies bacterianas durante o desenvolvimento da soja, surgindo as espécies R. pickettii, Burkholderia sp., Acitenobacter sp. e A. calcoaceticus durante o início do desenvolvimento, Stenotrophomonas maltophilia, 
Xanthomonas sp. Herbaspirillum sp. (não cultiváveis, detectadas por DGGE) e E. sakazaki durante a fase intermediária e Pseudomonas spp. no final do ciclo.

Bactérias endofíticas e epifíticas foram localizadas principalmente nas raízes, apresentando um gradiente decrescente das raízes às folhas. Resultados semelhantes foram relatados em milho e ervilha (Fisher et al., 1992; McInroy e Kloepper, 1995 Lamb et al., 1996; Elvira-Recuenco e Van Vuurde, 2000), sugerindo que os endófitos podem se locomover das raízes para regiões superiores do hospedeiro, durante desenvolvimento da planta. Além disso, pode-se sugerir que a principal região de entrada dos endófitos deva ser a raiz e regiões basais do hospedeiro e, que a partir daí, possam se disseminar no interior da planta. A colonização preferencial de bactérias endofíticas e epifíticas na região da raiz reflete a presença de altos níveis de nutrientes localizados na rizosfera e rizoplano, os quais podem ser utilizados para o crescimento e metabolismo bacterianos (Glick, 1995). Em relação ao estádio de desenvolvimento do hospedeiro, a fase R6 apresentou maior densidade populacional tanto para a comunidade endofítica quanto para a epifítica, podese argumentar que durante esta fase as populações bacterianas estão bem estabelecidas e, sob condições favoráveis, o seu nível populacional pode crescer mais rapidamente.

Alguns grupos bacterianos colonizaram preferencialmente tecidos específicos de soja. Bactérias pertencentes aos gêneros Ralstonia e Burkholderia só foram recuperadas de raízes e bactérias pertencentes ao gênero Acinetobacter de caules, sugerindo que estas bactérias poderiam ter uma interação específica com estes tecidos. Entretanto, o grupo de Proteobacteria prevaleceu nas comunidades bacterianas endofíticas e epifíticas e sua subdivisão gama foi mais abundante e diversa, tanto na avaliação por métodos de cultivos tradicionais quanto pela técnica de DGGE. É possível suger que este grupo seja importante no desenvolvimento da planta hospedeira, pois, é conhecido que representantes dos gêneros Pseudomonas, Pantoea, Enterobacter, Klebsiella, entre outros, podem promover o crescimento vegetal e 
atuarem no controle biológico de doenças de plantas (Patten \& Glick, 1996; Rodriguéz et al., 2000; Sturz et al., 2000; Verma et al., 2001).

No presente estudo, bactérias Gram-positivas (Bacillus sp. e actinomicetos) foram observadas em freqüência muito baixa. Este resultado também foi observado por outros trabalhos com soja. May et al. (1997) relataram que bactérias Gram-positivas foram observadas em menor freqüência em relação a bactérias Gram-negativas durante o monitoramento de bactérias colonizando folhas de soja. Da mesma forma, Bai et al. (2002) recuperaram apenas 17 isolados de Bacillus de nódulos de soja que tinham sido previamente esterilizados.

Comparações genéticas e fisiológicas entre comunidades bacterianas endofíticas e epifíticas poderia ser uma ferramenta útil para a determinação de que isolados endofíticos são, ou não, uma extensão de populações de linhagens epifíticas. Neste ponto de vista, as árvores filogenéticas baseadas na análise do sequenciamento parcial do $16 \mathrm{~S}$ rDNA, apresentada neste estudo, revelaram íntima relação entre isolados endofíticos e epifíticos. Estes resultados apóiam a hipótese de que uma possível origem das bactérias endofíticas seja populações epifíticas ou da rizosfera (Hallmann et al., 1997b; Sturz et al., 2000). A capacidade das bactérias em colonizar os tecidos vegetais, interiormente e superficialmente, é desejável do ponto de vista biotecnológico, pois, as bactérias terão maior possibilidade de influenciar o desenvolvimento do hospedeiro.

Recentemente, alguns trabalhos estão sendo desenvolvidos com a utilização da análise de DGGE em comunidades endofíticas, como por exemplo, a avaliação da interação de populações bacterianas endofíticas de citros e Xylella fastidiosa (Araújo et al., 2002) e a análise da comunidade bacteriana endofítica de batata (Garbeva et al., 2001). No presente trabalho, a utilização da técnica de DGGE permitiu observar que as diferenças fisiológicas entre as plantas de ciclo precoce e tardio durante a fase vegetativa apresentam pouca ou nenhuma influencia sobre a colonização bacteriana endofítica da raiz. 
Além disto, permitiu a detecção da possível influência da aplicação do herbicida glifosato na colonização e diversidade de bactérias endofíticas de raiz durante o estádio de desenvolvimento inicial do hospedeiro (V6), apresentando grupos específicos de acordo com o tratamento, fato este não observado nos experimentos de cultivo de bactérias.

A fase R2 (florescimento) apresentou perfil de DGGE mais heterogêneo corroborando com os dados analisados pela técnica de cultivo bacteriano em meio de cultura, no qual também foi observada maior diversidade de grupos bacterianos nesta fase fisiológica do hospedeiro. Além disto, esta fase apresentou grupos específicos que não foram recuperados nos experimentos de cultivo, como por exemplo, S. maltophilia e Xanthomonas sp. detectados apenas nos tratamentos sem glifosato, sugerindo que estes gêneros possam ser selecionados negativamente pela aplicação pré-plantio do herbicida glifosato. O inverso foi observado com Herbaspirillum sp., ou seja, sua presença foi detectada apenas em plantas cultivadas em solo tratado com o herbicida. A hipótese que o glifosato possa ser tóxico para bactérias é corroborada por alguns trabalhos que descrevem o mecanismo de ação deste herbicida e interação com microrganismos do solo (Levesque \& Rahe, 1992; Santos \& Flores, 1995; Nicholson \& Hirsch, 1998; Busse et al., 2001). Este herbicida é rapidamente adsorvido a partículas do solo, apresentando correlação positiva com o conteúdo de argila, e dificilmente é lixiviado, podendo, portanto, ser lentamente degradado ou persistir no solo durante anos (Levesque \& Rahe, 1992; Amarante-Jr, et al., 2002b). Diante destes resultados, pode-se inferir que um aumento significativo da aplicação de glifosato poderia resultar em uma alteração na comunidade bacteriana associada à soja. Portanto, estes resultados ressaltam a importância da utilização da técnica de DGGE para o estudo de microrganismos relacionados a plantas, principalmente bactérias endofíticas, uma vez que, por meio desta técnica foi possível avaliar grupos bacterianos não cultiváveis nas condições utilizadas, possibilitando melhor entendimento da interação endófito-hospedeiro. 


\subsection{Conclusões}

Os resultados apresentados permitem concluir que:

a) na interação bactéria-soja, a colonização bacteriana pode ser influenciada pelos estádios fenológicos do hospedeiro, genótipos da planta e tecidos vegetais;

b) o tratamento do solo, com o herbicida glifosato (pré-plantio), pode influenciar a diversidade de bactérias endofíticas e epifíticas, inclusive bactérias não-cultiváveis;

c) o grupo Proteobacteria, principalmente a subdivisão gama, é predominante entre as bactérias associadas à soja;

d) alguns isolados endofíticos apresentam íntima relação filogenética com isolados epifíticos. 


\section{DIVERSIDADE GENÉTICA DE BACTÉRIAS ASSOCIADAS À SOJA E SEU POTENCIAL PARA PROMOÇÃO DE CRESCIMENTO VEGETAL}

\section{Resumo}

Diversos estudos mostram que tanto bactérias endofíticas quanto bactérias epifíticas podem estimular o crescimento vegetal. Há diferentes mecanismos envolvidos na promoção de crescimento vegetal, incluindo controle biológico, resistência sistêmica induzida contra patógenos vegetais, fixação de $\mathrm{N}_{2}$, produção de fitohôrmonios e disponibilização de nutrientes. Desta forma, o estudo da interação microrganismos-soja permitirá a utilização aplicada destas bactérias na cultura da soja (Glycine max), que mesmo sendo importante economicamente tem sido pouco estudada quanto a sua interação com bactérias associadas. O objetivo deste trabalho foi avaliar o potencial para promoção de crescimento vegetal de bactérias endofíticas e epifíticas de soja e estudar a variabilidade genética destas bactérias por análise de restrição do 16S rDNA (ARDRA). Foram avaliadas 734 bactérias endofíticas e epifíticas isoladas de folhas, caules e raízes de duas cultivares (Foscarin e Cristalina), durante diferentes estádios de desenvolvimento vegetal, quanto a seu potencial para promoção de crescimento vegetal por meio da produção de ácido indol acético (AIA) e solubilização de fosfato inorgânico. A freqüência de produtores de AIA foi mais alta na população endofítica $(33,78 \%)$ que na epifítica $(20,77 \%)$, enquanto que a freqüência de solubilizadores de fosfato inorgânico foi de $49,33 \%$ e $51,80 \%$ para as comunidades endofíticas e epifíticas, respectivamente. As plantas de ciclo precoce (cv. Foscarin) apresentaram maior 
freqüência de bactérias produtoras de AIA. Foi observado também que bactérias solubilizadoras de fosfato foram mais freqüentemente isoladas a partir de plantas na fase de desenvolvimento vegetativo (V6). Além disso, 60,0\% e $68,9 \%$ dos isolados endofíticos e epifíticos, respectivamente, que produziram AIA e solubilizaram fosfato inorgânico, também foram capazes de fixar $N_{2}$. Bactérias associadas à soja potencialmente promotoras de crescimento vegetal, pertencentes às espécies Pseudomonas orizyhabitans, Ralstonia pickettii e Pantoea sp., em experimentos de casa de vegetação, foram capazes de aumentar o peso da raiz e da parte aérea (caule mais folhas) de soja, mostrando que estas bactérias poderiam ser utilizadas na promoção de crescimento vegetal. A análise da diversidade genética por ARDRA revelou 43 haplótipos associados ao hospedeiro. Foi observado também que o herbicida glifosato, cultivares de soja, estádios de desenvolvimento do hospedeiro e tecidos vegetais podem influenciar o grau de diversidade genética destas bactérias. Estes resultados sugerem que isolados endofíticos e epifíticos tem potencial para serem utilizados na promoção do crescimento de soja por meio da suplementação de auxina, disponibilização de fosfato e $N_{2}$ orgânico para as plantas hospedeiras.

\section{Summary}

Many studies have demonstrated that endophytic and epiphytic bacteria may stimulate host plant growth. There are several possible mechanisms for plant growth promotion including biological control of diseases, induced systemic resistance to plant pathogens, nitrogen fixation, phytohormone production and enhancement of nutrients. Although soybean (Glycine max) is economically important for Brazil and the world, few studies of the interaction microorganisms-plant were accomplished. Therefore, the aims of this work were to evaluate the potential for plant growth promotion of endophytic and epiphytic bacteria from soybean and study the genetic variability of these bacteria by $16 \mathrm{~S}$ 
rDNA restriction analysis (ARDRA). A collection of 734 soybean endophytic and epiphytic bacteria, isolated from leaves, stems and roots of two soybean cultivars (Foscarin and Cristalina), during plant growth different stages, was evaluated in such characters as indoleacetic acid production (IAA) and mineral phosphate solubilization. The frequency of IAA producers was higher $(33.78 \%)$ in endophytic than in epiphytic population $(20.77 \%)$, while the frequency of phosphate solubilization was $49.33 \%$ and $51.80 \%$ for endophytic and epiphytic communities, respectively. The precocious ripening plants (cv. Foscarin) showed a high frequency of IAA producing bacteria as well as the soybean plants in initial development stage (V6) presented a high percentage of phosphate solubilizing bacteria. Furthermore, $60.0 \%$ and $68.9 \%$ of endophytic and epiphytic isolates that produced IAA and solubilized mineral phosphate also were able to fix atmospheric nitrogen. Potentially plant growth promoting soybean-associated bacteria belong to the species Pseudomonas orizyhabitans, Ralstonia pickettii, and Pantoea sp., increased, in greenhouse experiments, root and aerial part (stem plus leaves) weight of soybean, showing that these bacteria could be used in plant growth promotion. Furthermore, the genetic variability analysis by ARDRA, detected at least 43 haplotypes associated to soybean. It was also observed that this variability may be changed by glyphosate application, soybean cultivar, plant growth stages, and plant tissues.

These results suggested that endophytic and epiphytic isolates could be used to improve the soybean growth by supplying auxin, enhancement of phosphate and organic $\mathrm{N}_{2}$ to soybean plants.

\subsection{Introdução}

Bactérias são habitantes comuns da superfície e do interior da maioria das plantas, podendo apresentar relações neutras e simbióticas com o hospedeiro. As bactérias associadas às plantas são denominadas de bactérias endofíticas quando habitam o interior da planta sem causar dano aparente ao 
hospedeiro (Petrini, 1991; Hallmann et al., 1997b; Azevedo, 1998a, Sturz et al. 2000) e de bactérias epifíticas quando crescem e se estabelecem sobre a superfície vegetal (rizoplano ou filoplano) (Petrini, 1991; Jacques \& Morris, 1995; Reinhold-Hurek \& Hurek, 1998; Andrews \& Harris, 2000). Entretanto, existem algumas populações bacterianas que podem flutuar entre a colonização endofítica e epifítica (Hallmann et al., 1997b; Azevedo et al., 2000b; Sabaratnam \& Beattie, 2003).

Bactérias endofíticas e epifíticas podem contribuir para o crescimento, saúde e desenvolvimento vegetal. A promoção de crescimento vegetal por estas bactérias pode ser resultado tanto de ações indiretas, como o controle biológico por competição de nutrientes, produção de sideróforos, antibiose e indução de resistência sistêmica no hospedeiro (Sturz \& Matheson, 1996; Van Loon et al., 1998; Sturz et al., 2000; Ramamoorthy et al., 2001), como de ações diretas, como o suprimento de nutrientes para a planta, fixação de nitrogênio atmosférico e a produção de reguladores de crescimento vegetal (Glick, 1995; Chanway, 1998; Shishido et al., 1999; Sturz et al., 2000).

O mecanismo de promoção de crescimento vegetal por bactérias é um processo complexo que pode ser influenciado por diversos fatores bióticos e abióticos (Bloemberg \& Lugtenberg, 2001). Neste aspecto, os estudos de ecologia microbiana que buscam aumentar e consolidar os conhecimentos a respeito dos processos interativos no ambiente podem auxiliar o entendimento deste processo. Além disso, nos últimos anos novas abordagens metodológicas, principalmente de genética molecular, têm sido muito úteis na geração de um quadro mais completo sobre a interação microbiana em diferentes habitats (Van Elsas et al., 1998; Ranjard et al., 2000). Embora exista um grande número de técnicas, que revelam polimorfismo de DNA, é importante considerar o tipo de organismo em estudo. Neste contexto, a técnica de ARDRA (Amplified Ribosomal DNA Restriction Analysis), que consiste na amplificação do rDNA e digestão com enzimas de restrição, é baseada no princípio de que os sítios de restrição na seqüência do RNA são conservados 
de acordo com padrões filogenéticos. Se o estudo a ser realizado tem por objetivo a avaliação da diversidade em um grupo microbiano heterogêneo, deve ser avaliada a seqüência do $16 \mathrm{~S}$ rDNA, enquanto que se o grupo apresentar alta similaridade, deve ser utilizada a seqüência da região espaçadora entre o $16 S$ e o 23 S rDNA (Heyndrickx et al., 1996; Van Elsas et al., 1998; Ranjard et al., 2000).

Do ponto de vista biotecnológico, bactérias que possuam mais de uma característica para a promoção de crescimento vegetal, como, por exemplo, fixar $\mathrm{N}_{2}$ e solubilizar fosfato ou produzir auxina e sideróforos, entre outras, são almejadas e rastreadas para uma possível aplicação no campo objetivando o aumento de produção agrícola (Verma et al., 2001). Além disso, poucos trabalhos explorando estes aspectos foram realizados em microrganismos associados à soja.

Desta forma, o presente trabalho teve como objetivos: (i) selecionar bactérias associadas à soja com capacidade para produzir auxina, solubilizar fosfato inorgânico e fixar nitrogênio atmosférico; (ii) avaliar a possível influência de diferentes fatores (aplicação do herbicida glifosato, estádios de desenvolvimento do hospedeiro, genótipo da planta e tecidos vegetais) sobre a comunidade bacteriana endofítica e epifítica com potencial para promoção de crescimento vegetal; (iii) estudar a diversidade genética de bactérias endofíticas e epifíticas por marcador ARDRA e (vi) avaliar o efeito de bactérias endofíticas potencialmente promotoras de crescimento vegetal sobre plântulas de soja. 


\subsection{Material e Métodos}

\subsubsection{Isolados bacterianos e condições de cultivo}

Foram utilizadas 373 bactérias endofíticas e 361 bactérias epifíticas isoladas de folha, caule e raiz de plantas de soja [Glycine max (L.) Merrill], cultivares Foscarin e Cristalina, cultivadas em solo com e sem aplicação préplantio do herbicida glifosato, durante três estádios de desenvolvimento do hospedeiro (V6, R2 e R6), nas safras 2000/01 e 2001/02.

Os isolados bacterianos foram estocados em meio líquido TSA $10 \%$ (Trypcase Soy Agar) suplementado com $20 \%$ de glicerol a $-70^{\circ} \mathrm{C}$ e em meio TSA $10 \%$ sólido a $4^{\circ} \mathrm{C}$. Para a produção de culturas novas, os isolados foram repicados em TSA $10 \%$ durante os experimentos.

Do total de bactérias endofíticas e epifíticas utilizadas, 170 isolados foram previamente identificados por análise da seqüência parcial do 16S rDNA ou por análise de ácidos graxos totais da célula bacteriana (FAME - Fatty Acid Methyl Esters). A Tabela 1 apresenta a taxonomia dos grupos bacterianos identificados.

\subsubsection{Seleção de bactérias produtoras de ácido indol acético (AIA)}

A seleção de bactérias produtoras de AIA (auxina) foi realizada utilizando-se a técnica qualitativa segundo Bric et al. (1991). As bactérias foram inoculadas em placas de Petri (16 isolados por placa) contendo meio sólido TSA $10 \%$ suplementado com $5 \mathrm{mM}$ de L-triptofano, imediatamente cobertas com membrana de nitrocelulose (Amersham Pharmacia) e incubadas por $24 \mathrm{~h} \mathrm{a}$ $28^{\circ} \mathrm{C}$. Em seguida, a membrana foi removida e tratada com $10 \mathrm{ml}$ do reagente de Salkowski (2\% de $\mathrm{FeCl}_{3}$ 0,5 $\mathrm{M}$ em 35\% de ácido perclórico). A reação foi mantida à temperatura ambiente por $10 \mathrm{~min}$. Como controle positivo foi utilizada 
a linhagem endofítica de citros, produtora de AIA, ARB/18 (Pantoea agglomerans) (Araújo, 2000). Os experimentos foram realizados em duplicatas e a presença de um halo rosa em torno da colônia indicou produção de AIA.

Tabela 1. Identificação e distribuição taxonômica dos grupos bacterianos de isolados endofíticos (EN) e epifíticos (EP) de soja

\begin{tabular}{|c|c|c|c|c|}
\hline \multirow{2}{*}{ Grupo } & \multicolumn{2}{|c|}{$\mathrm{N}^{\circ}$ Isolados } & \multirow{2}{*}{$\begin{array}{c}\text { Filiação } \\
\text { Taxonômica }\end{array}$} & \multirow{2}{*}{ Espécies } \\
\hline & EN & EP & & \\
\hline G1 & 3 & 1 & $\beta$-Proteobacteria & Ralstonia picketti \\
\hline G2 & 28 & 13 & $\gamma$-Proteobacteria & $\begin{array}{l}\text { Pseudomonas sp., } P \text {. oryzihabitans } \\
\text { e P. citronellolis }\end{array}$ \\
\hline G3 & 14 & 8 & $\gamma$-Proteobacteria & $\begin{array}{l}\text { Enterobacter agglomerans e } \\
\text { Enterobacteriaceae }\end{array}$ \\
\hline G4 & 6 & 2 & $\beta$-Proteobacteria & Burkholderia sp. \\
\hline G5 & 6 & 1 & $\gamma$-Proteobacteria & $\begin{array}{l}\text { Pseudomonas sp., } P \text {. straminea e } \\
\text { P. fulva }\end{array}$ \\
\hline G6 & 1 & 0 & $\beta$-Proteobacteria & Ralstonia picketti \\
\hline G7 & 43 & 29 & $\gamma$-Proteobacteria & $\begin{array}{l}\text { Klebsiella pneumoniae, K. oxytoca, } \\
\text { Erwinia sp., e Enterobacteriacea }\end{array}$ \\
\hline G8 & 1 & 2 & $\gamma$-Proteobacteria & $\begin{array}{l}\text { Acinetobacter } \mathrm{sp} . \mathrm{e} \\
\text { A. calcoaceticus }\end{array}$ \\
\hline G9 & 2 & 1 & $\gamma$-Proteobacteria & Enterobacter sakazaki \\
\hline G10 & 2 & 1 & $\gamma$-Proteobacteria & Pseudomonas sp. \\
\hline G11 & 4 & 2 & $\alpha$-Proteobacteria & $\begin{array}{l}\text { Agrobacterium sp. e } \\
\text { Caulobacter/Asticcacaulis }\end{array}$ \\
\hline
\end{tabular}

\subsubsection{Seleção de bactérias solubilizadoras de fosfato inorgânico}

A seleção de bactérias solubilizadoras de fosfato foi realizada segundo Verma et al. (2001) e Rodriguez et al. (2000), com algumas modificações. As bactérias foram inoculadas em meio de cultura sólido contendo fosfato insolúvel (10 g/l de glicose; $5 \mathrm{~g} / \mathrm{l}$ de $\mathrm{NH}_{4} \mathrm{Cl} ; 1 \mathrm{~g} / \mathrm{l}$ de NaCl; $1 \mathrm{~g} / \mathrm{l}$ de $\mathrm{MgSO}_{4} .7 \mathrm{H}_{2} \mathrm{O} ; 0,8 \mathrm{~g} / \mathrm{l}$ de 
$\mathrm{Ca}_{3} \mathrm{HPO}_{4} ; 15 \mathrm{~g} / \mathrm{l}$ de agar; $\mathrm{pH} 7,2$ ). As placas foram incubadas a $28^{\circ} \mathrm{C}$ por $48 \mathrm{~h} \mathrm{e}$, em seguida, realizadas as leituras. Os experimentos foram realizados em duplicatas e a presença de um halo claro em torno da colônia indicou a solubilização do fosfato.

\subsubsection{Seleção de bactérias com capacidade de fixar $\mathrm{N}_{2}$}

\subsubsection{Crescimento de bactérias em meio de cultura livre de nitrogênio}

As linhagens de bactérias endofíticas e epifíticas que apresentaram a capacidade de produzir auxina e solubilizar fosfato inorgânico foram avaliadas quanto à capacidade de fixar $\mathrm{N}_{2}$ por meio do crescimento em meio de cultura sem fonte de nitrogênio. Para tanto, as bactérias foram inoculadas em tubos de ensaio contendo $10 \mathrm{ml}$ de meio de cultura NFb [5 g/l de ácido málico; 0,5 g/l de $\mathrm{K}_{2} \mathrm{HPO}_{4} ; 0,2 \mathrm{~g} / \mathrm{l}$ de $\mathrm{MgSO}_{4} .7 \mathrm{H}_{2} \mathrm{O} ; 0,1 \mathrm{~g} / \mathrm{l}$ de $\mathrm{NaCl} ; 0,01 \mathrm{~g} / \mathrm{l}$ de $\mathrm{CaCl}_{2} .2 \mathrm{H}_{2} \mathrm{O} ; 4 \mathrm{ml} / \mathrm{l}$ de Fe.EDTA (solução 1,64\%); $2 \mathrm{ml} / \mathrm{l}$ de azul de bromotimol $(0,5 \%) ; 2 \mathrm{ml} / / \mathrm{de}$ solução de micronutrientes $\left(0,2 \mathrm{~g} / \mathrm{I}\right.$ de $\mathrm{Na}_{2} \mathrm{MoO}_{4} \cdot 2 \mathrm{H}_{2} \mathrm{O} ; 0,235 \mathrm{~g} / \mathrm{l}$ de $\mathrm{MnSO}_{4} \cdot \mathrm{H}_{2} \mathrm{O}$; $0,28 \mathrm{~g} / \mathrm{l}$ de $\mathrm{H}_{3} \mathrm{BO}_{3} ; 0,008 \mathrm{~g} / \mathrm{l}$ de $\left.\mathrm{CuSO}_{4} .5 \mathrm{H}_{2} \mathrm{O}\right) ; 1,75 \mathrm{~g} / \mathrm{l}$ de agar; $\left.\mathrm{pH} 6,8\right]$, incubadas a $28^{\circ} \mathrm{C}$ e avaliadas após 7 dias de crescimento. $\mathrm{O}$ resultado positivo foi caracterizado pela presença de um halo de crescimento no interior do meio de cultura.

\subsubsection{Detecção do gene da nitrogenase (nifH) por meio de PCR}

A presença do gene que codifica a subunidade $\mathrm{Fe}$ da enzima nitrogenase (nifH) foi avaliada por meio da técnica de PCR com a utilização dos primers específicos 19F (5'-GCIWTYTAYGGIAARGGIGG-3') e 407R (5'- 
AAICCRCCRCAIACIACRTC-3'), segundo Ueda et al. (1995). As reações de PCR foram realizadas em um volume final de $25 \mu \mathrm{l}$, contendo 0,5 a $10 \mathrm{ng}$ de DNA molde; $1 \mu \mathrm{M}$ de cada primer; 0,2 mM de cada dNTPs; $1,5 \mathrm{mM}$ de $\mathrm{MgCl}_{2} \mathrm{e}$ 0,05 U da enzima Taq DNA polimerase (Invitrogen) em $20 \mathrm{mM}$ de Tris- $\mathrm{HCl} \mathrm{pH}$ 8,4 e $50 \mathrm{mM} \mathrm{KCl}$. Em todas as reações foram utilizados dois controles positivos, com o DNA molde da linhagem SR1.6/6 de Methylobacterium mesophilicum (Araújo, 2000) e da linhagem BR11281 de Gluconoacetobacter diazotrophicus (EMBRAPA/Agrobiologia), e um controle negativo sem o DNA molde.

A reação de amplificação foi realizada em termociclador (Perkin-Elmer GeneAmp ${ }^{\circledR}$ PCR System 9700) programado para realizar uma desnaturação inicial a $94^{\circ} \mathrm{C}$ por 5 min, 35 ciclos de desnaturação a $94^{\circ} \mathrm{C}$ por $30 \mathrm{~s}$, anelamento a $59^{\circ} \mathrm{C}$ por 1 min e extensão dos primers a $72^{\circ} \mathrm{C}$ por $30 \mathrm{~s}$, seguida de extensão final a $72^{\circ} \mathrm{C}$ por $7 \mathrm{~min}$. Após a amplificação, $10 \mu \mathrm{l}$ da reação de PCR foram avaliados por eletroforese em gel de agarose $(1,2 \%$ p/v) em tampão 1x TAE (40 $\mathrm{mM}$ de Tris-acetato; $1 \mathrm{mM}$ de EDTA) e corado com brometo de etídio (0,5 $\mu \mathrm{g} / \mathrm{ml}$ ), segundo Sambrook et al. (1989), para visualização de um fragmento de 300 a $400 \mathrm{pb}$.

\subsubsection{Extração de DNA genômico de bactérias}

As linhagens foram cultivadas em $5 \mathrm{ml}$ de TSA $10 \%$ líquido por $24 \mathrm{~h}$ a $28^{\circ} \mathrm{C}$ sob agitação de $150 \mathrm{rpm}$. Dois a $4 \mathrm{ml}$ da cultura foram centrifugados por 5 min a $14000 \mathrm{~g}$ e as células ressuspendidas em $500 \mu \mathrm{l}$ de TE (10 mM de Tris$\mathrm{HCl}$; $\mathrm{pH} 8,0$ ), centrifugadas, e ressuspendidas novamente em $500 \mu \mathrm{l}$ de TE com o acréscimo de $0,5 \mathrm{~g}$ de pérolas de vidro $(0,1 \mathrm{~mm}$ de diâmetro - Sigma ) e $15 \mu \mathrm{l}$ de SDS $20 \%$. As células foram agitadas em homogeneizador (MineBeadbeater $^{T M}$, Biospec Products) por $30 \mathrm{~s}$ a 3500 bpm. Ao lisado celular foram adicionados $500 \mu \mathrm{l}$ de fenol, homogeneizados por inversão e centrifugado por 5 min a $14000 \mathrm{~g}$. A fase aquosa foi extraída uma vez com fenol-clorofórmio (1:1) e uma vez com clorofórmio, então, o DNA foi precipitado com 1/10 volume de 
$\mathrm{NaCl} 5 \mathrm{M}$ e 0,6 volume de isopropanol ( 3 min à temperatura ambiente) e coletado por centrifugação (10 min a $14000 \mathrm{~g}$ ). O precipitado de DNA foi lavado com etanol $70 \%$, seco a $37^{\circ} \mathrm{C}$ e ressuspendido em $50 \mu \mathrm{l}$ de água milli-Q esterilizada. O DNA total foi analisado por eletroforese com gel de agarose $(0,8 \% \mathrm{p} / \mathrm{v})$ em tampão $1 \times$ TAE e corado com brometo de etídio $(0,5 \mu \mathrm{g} / \mathrm{ml})$.

\subsubsection{Amplificação e restrição do 16S rDNA (ARDRA)}

A amplificação do $16 S$ rDNA foi realizada por meio a técnica de PCR com os primers universais P027F (5'-GAGAGTTTGATCCTGGCTCAG-3') e 1378R (5'-CGGTGTGTACAAGGCCCGGGAACG-3'). As reações apresentaram um volume final de $50 \mu \mathrm{l}$ contendo 0,5 a $10 \mathrm{ng}$ de DNA molde; $0,2 \mu \mathrm{M}$ de cada primer; 0,2 $\mathrm{mM}$ de cada dNTPs; 3,75 $\mathrm{mM}$ de $\mathrm{MgCl}_{2}$ e 0,05 $\mathrm{U}$ da enzima Taq DNA polimerase (Invitrogen) em $20 \mathrm{mM}$ de Tris- $\mathrm{HCl}$ pH 8,4 e $50 \mathrm{mM} \mathrm{KCl}$. Em todas as reações foi utilizado um controle negativo sem o DNA molde.

A reação de amplificação foi realizada em termociclador (Perkin-Elmer GeneAmp ${ }^{\circledR}$ PCR System 9700) programado para realizar uma desnaturação inicial a $94^{\circ} \mathrm{C}$ por $4 \mathrm{~min}, 25$ ciclos de desnaturação a $94^{\circ} \mathrm{C}$ por $30 \mathrm{~s}$, anelamento a $63^{\circ} \mathrm{C}$ por 1 min e extensão de primers a $72^{\circ} \mathrm{C}$ por $1 \mathrm{~min}$, seguida de extensão final a $72^{\circ} \mathrm{C}$ por $7 \mathrm{~min}$. Após a amplificação, $5 \mu \mathrm{l}$ da reação de PCR foram avaliados por eletroforese em gel de agarose (1,2\% p/v) em tampão 1x TAE e corado com brometo de etídio $(0,5 \mu \mathrm{g} / \mathrm{ml})$, para visualização de um fragmento de aproximadamente $1350 \mathrm{pb}$.

A variabilidade genética das bactérias endofíticas e epifíticas foi analisada utilizando-se a técnica de ARDRA (Amplified Ribosomal DNA Restriciton Analysis). Para isso, $1 \mu \mathrm{g}$ do fragmento de $16 \mathrm{~S}$ rDNA amplificado foi clivado com as enzimas de restrição $\mathrm{Mbol}$, Alul e Haelll, separadamente, de acordo com as recomendações do fabricante (Invitrogen). Após a digestão, toda a reação foi analisada por eletroforese em gel de agarose $(2,5 \% \mathrm{p} / \mathrm{v}) \mathrm{em}$ tampão 1x TAE, juntamente com o marcador de peso molecular DNA Ladder 
100 pb (Life Technologies). Em seguida, o gel foi corado com brometo de etídio $(0,5 \mu \mathrm{g} / \mathrm{ml})$, observado sobre luz ultravioleta e fotodocumentado.

\subsubsection{Avaliação de promoção de crescimento vegetal por bactérias endofíticas}

Foram utilizados 7 isolados endofíticos para a avaliação de promoção de crescimento vegetal em soja. As bactérias endofíticas foram inoculadas em meio líquido TSA $10 \%$ e incubadas por 24 h sob agitação constante (150 rpm). Em seguida, as culturas foram diluídas em tampão PBS (1,44 g/l de $\mathrm{Na}_{2} \mathrm{HPO}_{4}$; 0,24 g/l de $\mathrm{KH}_{2} \mathrm{PO}_{4} ; 0,20 \mathrm{~g} / \mathrm{l}$ de $\mathrm{KCl} ; 8,00 \mathrm{~g} / \mathrm{l}$ de $\mathrm{NaCl} ; \mathrm{pH}$ 7,4) para obtenção de inóculos em torno de $10^{6} \mathrm{UFC} / \mathrm{ml}$. Sementes da cultivar Cristalina foram incubadas com a suspensão bacteriana ou em tampão PBS (controle) por $1 \mathrm{~h}$ sob agitação (150 rpm). Após a inoculação, as sementes foram plantadas em vasos contendo substrato (PlantMax Hortaliças, Eucatex) e mantidas em casa de vegetação por 17 dias, sendo utilizadas 5 sementes por vaso e 3 repetições por tratamento.

\subsubsection{Análise estatística}

O teste do qui-quadrado $\left(\chi^{2}\right)(P=0.05)$ (Steel \& Torrie, 1980) foi aplicado para verificar a possível influência dos seguintes tratamentos: solo com e sem aplicação do herbicida glifosato em pré-plantio, genótipos do hospedeiro, estádios de desenvolvimento vegetal e tecidos da planta (considerados durante o processo de isolamento das bactérias analisadas neste trabalho), sobre a comunidade bacteriana endofítica e epifítica com capacidade de produzir auxina ou solubilizar fosfato inorgânico. 


\subsection{Resultados}

\subsubsection{Seleção de bactérias endofíticas e epifíticas produtoras de auxina e solubilizadoras de fosfato inorgânico}

Um total de 373 isolados endofíticos e 361 isolados epifíticos foram analisados quanto à capacidade de produzir ácido indol acético (AIA - auxina) e solubilizar fosfato inorgânico in vitro. As metodologias utilizadas para a seleção qualitativa destas características foram eficientes, pois permitiram boa leitura dos resultados (Figura 1). Foi possível observar que a freqüência de bactérias com capacidade de produzir auxina foi maior entre os isolados endofíticos (33,78\%) quando comparados aos isolados epifíticos $(20,77 \%)$. Além disso, foi analisada a possível influência dos diferentes fatores considerados durante o processo de isolamento das bactérias (tratamento do solo com glifosato em préplantio, genótipo do hospedeiro, estádios de desenvolvimento da soja e tecidos vegetais) sobre a freqüência de bactérias produtoras de auxina. Dentre os fatores, foi detectada interação entre o genótipo do hospedeiro e a freqüência de bactérias epifíticas produtoras de auxina (Figura 2), observando-se que a população bacteriana da cultivar Foscarin (ciclo precoce) apresentou maior freqüência de produtores de auxina que da cultivar Cristalina (ciclo tardio). Nenhuma interação significativa foi observada entre os outros fatores e as bactérias endofíticas e epifíticas produtoras de auxina. 

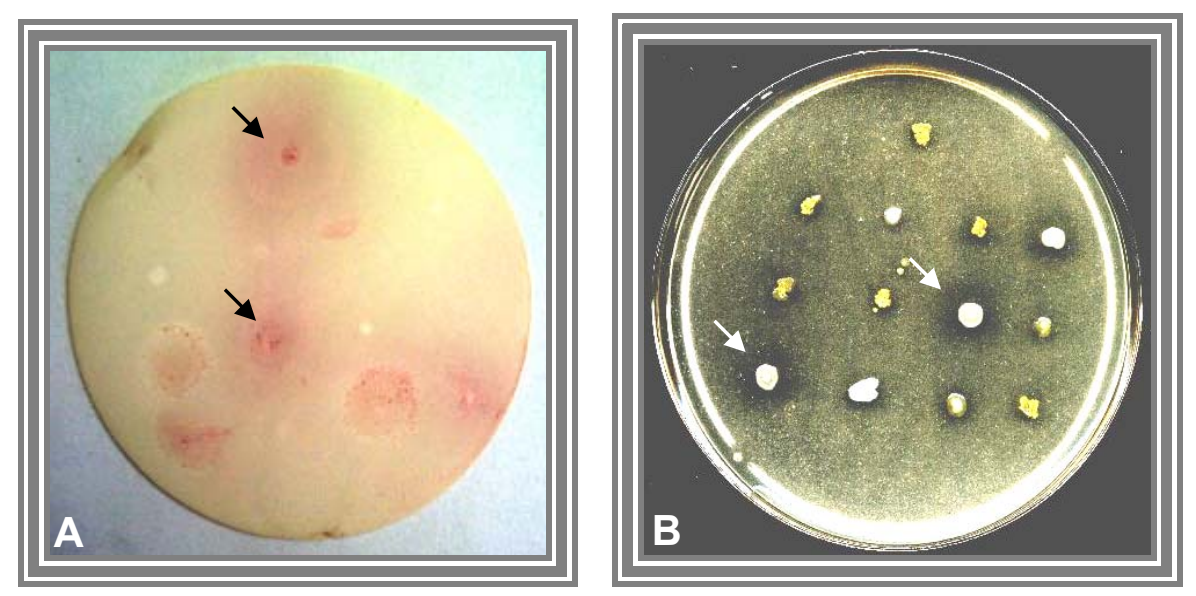

Figura 1 - A) Detecção de bactérias produtoras de auxina (AIA): membrana de nitrocelulose corada com o reagente de Salkowski; B) Detecção de bactérias solubilizadoras de fosfato inorgânico: crescimento bacteriano em meio de cultura suplementado com fosfato insolúvel

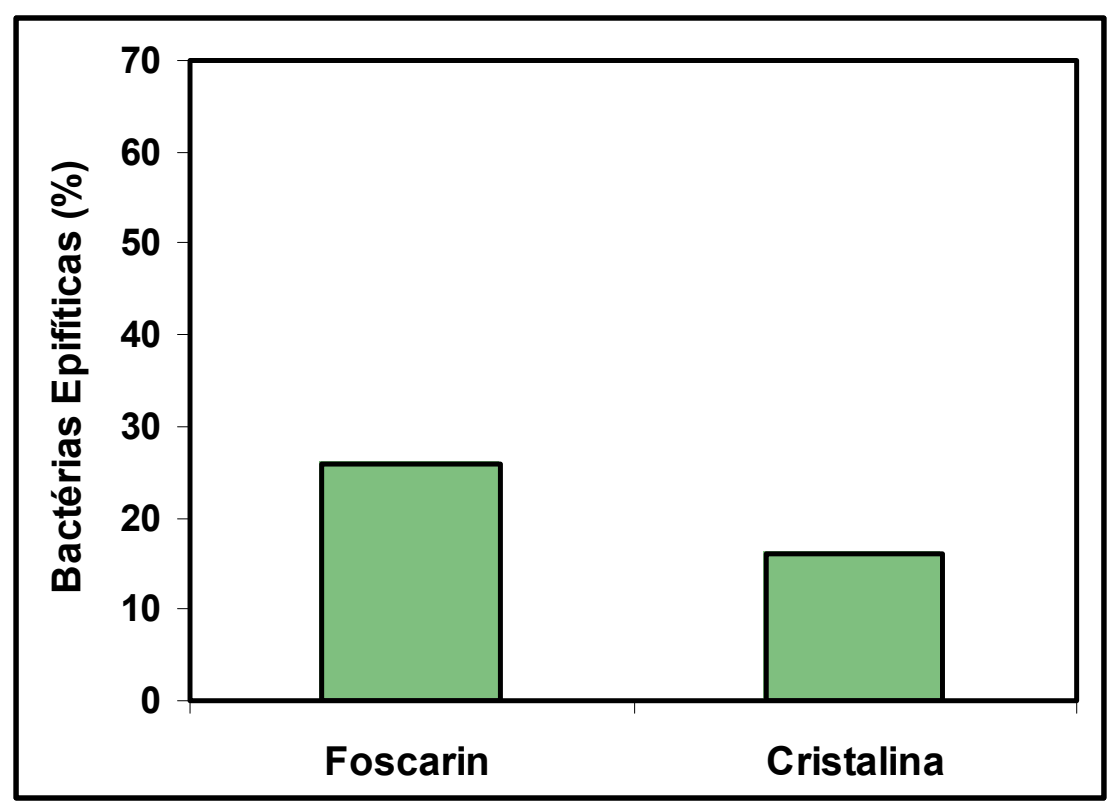

Figura 2 - Freqüência de bactérias epifíticas produtoras de auxina (AIA) em relação a cultivar da soja: Foscarin (ciclo precoce) e Cristalina (ciclo tardio). A análise pelo teste de $\chi^{2}$ revelou haver influência dos tratamentos $(P<0,05)$ 
Em relação à solubilização de fosfato inorgânico, não houve diferença significativa entre a freqüência de bactérias endofíticas $(49,33 \%)$ e bactérias epifíticas (51,80\%). Contudo, houve interação entre o estádio de desenvolvimento vegetal e a freqüência de isolados endofíticos solubilizadores de fosfato inorgânico (Figura 3), sendo maior o número de bactérias endofíticas com esta capacidade isoladas de plantas em fase V6 (vegetativa). Os outros fatores não apresentaram interação com os isolados endofíticos. Por outro lado, os isolados epifíticos foram observados em maior freqüência quando provenientes de folhas (Figura 4), sendo este fator (tecido vegetal) o único a apresentar interação com bactérias epifíticas.

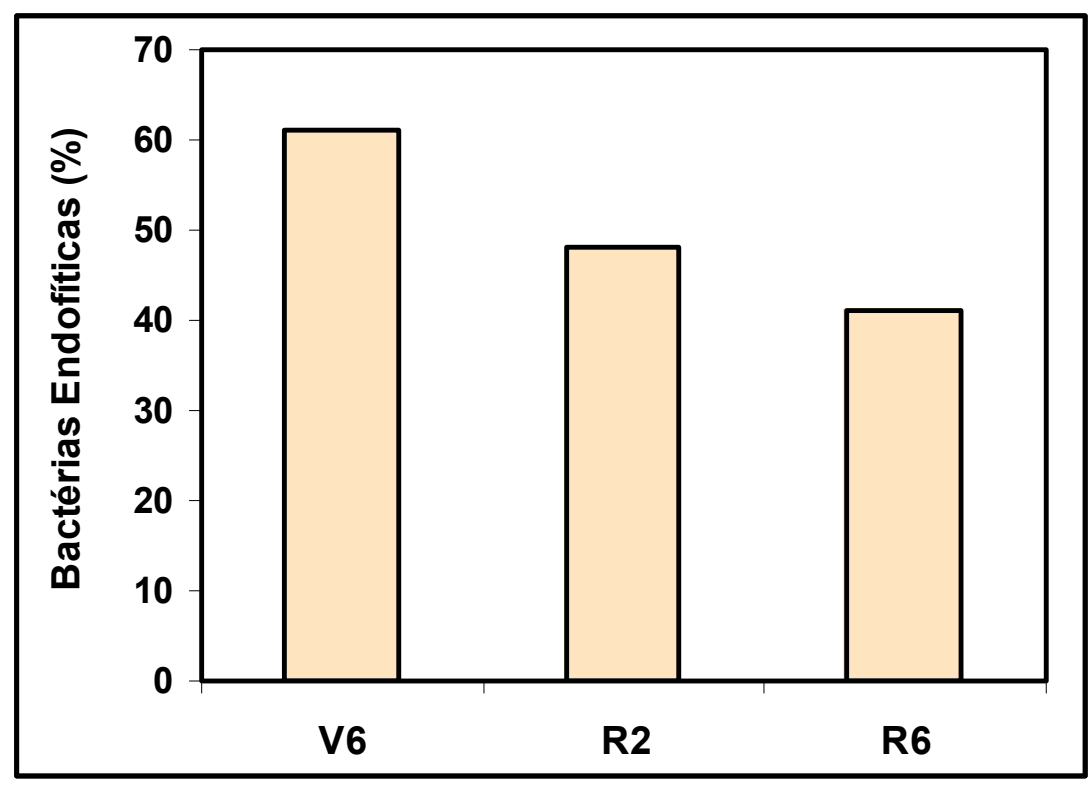

Figura 3 - Freqüência de bactérias endofíticas solubilizadoras de fosfato inorgânico em relação ao estádio de desenvolvimento vegetal: V6 (vegetativo), R2 (florescimento) e R6 (maturação). A análise pelo teste do $\chi^{2}$ revelou haver influência dos tratamentos $(P<0,05)$ 


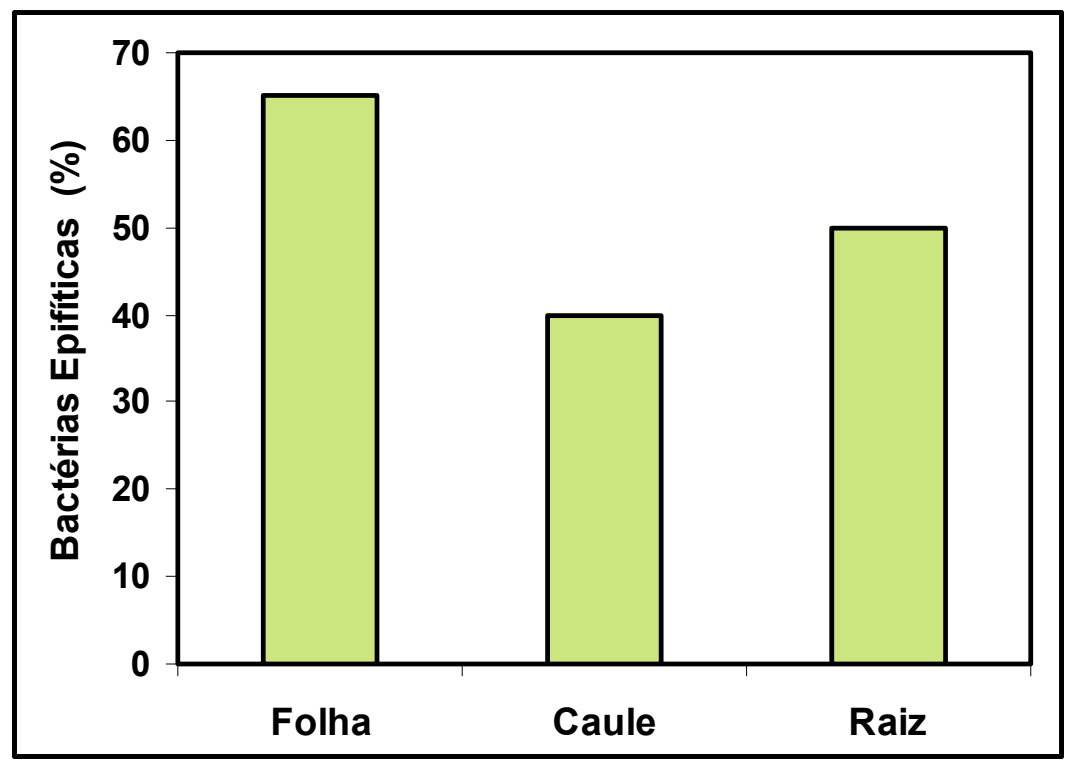

Figura 4 - Freqüência de bactérias epifíticas solubilizadoras de fosfato inorgânico em relação ao tecido do hospedeiro: Folha, Caule e Raiz. A análise pelo teste do $\chi^{2}$ revelou haver influência dos tratamentos $(P<0,05)$

A análise conjunta de bactérias produtoras de auxinas e solubilizadoras de fosfato mostrou que a população de bactérias endofíticas apresentou um percentual maior $(20,0 \%)$ de linhagens potencialmente promotoras de crescimento vegetal em relação ao percentual da população epifítica $(12,0 \%)$. Os grupos bacterianos mais freqüentes, com estas duas características, para as populações endofíticas e epifíticas foram G2 (Pseudomonadaceae), G3 e G7 (Enterobacteriaceae) (Tabela 1).

\subsubsection{Seleção de bactérias com potencial para fixar $\mathbf{N}_{2}$}

As bactérias endofíticas e epifíticas também foram avaliadas em relação ao potencial para fixar $\mathrm{N}_{2}$. Isolados endofíticos (75) e epifíticos (45) que apresentaram capacidade de produzir auxina e solubilizar fosfato inorgânico foram avaliados quanto à capacidade de fixar $\mathrm{N}_{2}$. 
O cultivo em meio NFb permitiu observar, por meio do halo de crescimento em meio de cultura (Figura 5), que 60,0\% dos isolados endofíticos e $68,9 \%$ dos isolados epifíticos foram capazes de crescer em meio NFb. Entre estes isolados os grupos predominantes foram Enterobacteriaceae (G7) e Pseudomonadaceae (G2) (Tabela 2).

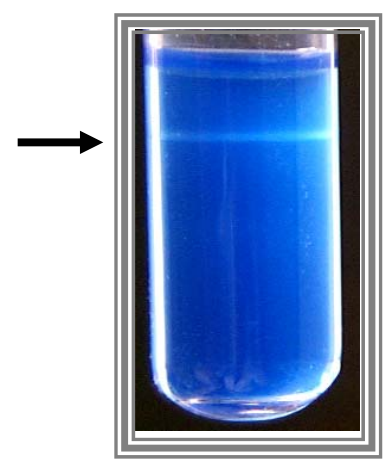

Figura 5 - Formação de halo (seta) de crescimento bacteriano em meio cultura $\mathrm{NFb}$ livre de $\mathrm{N}_{2}$

O PCR específico para o gene nifH revelou bandas variando entre 300 e $400 \mathrm{pb}$ (Figura 6), sendo observada a presença deste gene em apenas $21,3 \%$ dos isolados endofíticos e $8,9 \%$ dos isolados epifíticos. Estas bactérias foram previamente identificadas como Acinetobacter calcoaceticus, Ralstonia sp., Burkholderia sp., Pseudomonas spp. e espécies da família Enterobacteriaceae.

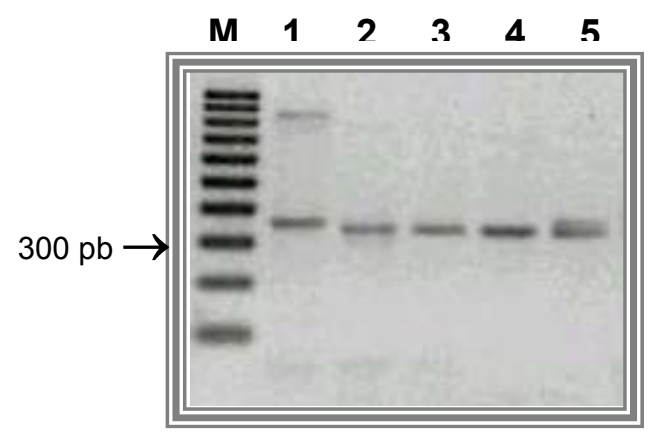

Figura 6 - PCR específico para o gene nifH. M) Marcador 100 pb (Fermentas); 1,2) Controles positivos - G. diazotrophicus e M. mesophilicum; 3,4) Isolados endofíticos; 5) Isolado epifítico 
Tabela 2. Isolados bacterianos endofíticos (EN) e epifíticos (EP) capazes de produzir auxina, solubilizar fosfato inorgânico e fixar $\mathrm{N}_{2}$ em meio $\mathrm{NFb}$

\begin{tabular}{cccccccc}
\hline Isolado & Grupo & Isolado & Grupo & Isolado & Grupo & Isolado & Grupo \\
\hline EN2 & G2 & EN136 & G7 & EN358 & G2 & EP103 & G7 \\
EN11 & G7 & EN141 & G9 & EN364 & G7 & EP111 & G3 \\
EN19 & G3 & EN151 & G7 & EN369 & nd & EP114 & G2 \\
EN21 & G1 & EN155 & G7 & EN371 & G7 & EP117 & G2 \\
EN36 & G2 & EN161 & G7 & EN380 & G7 & EP129 & G2 \\
EN58 & G2 & EN179 & G3 & EN414 & G7 & EP144 & G3 \\
EN65 & G2 & EN182 & G7 & EN425 & G7 & EP151 & G10 \\
EN67 & G10 & EN183 & G7 & EP2 & G7 & EP155 & G2 \\
EN69 & G3 & EN186 & G7 & EP8 & G7 & EP199 & G7 \\
EN78 & G3 & EN193 & G3 & EP25 & G7 & EP203 & G3 \\
EN80 & G3 & EN223 & G2 & EP29 & G7 & EP244 & G7 \\
EN85 & G7 & EN230 & G10 & EP37 & G7 & EP245 & G2 \\
EN91 & nd & EN248 & G2 & EP38 & G2 & EP253 & G3 \\
EN99 & G7 & EN268 & G2 & EP60 & G7 & EP254 & G2 \\
EN103 & G3 & EN281 & nd & EP68 & G7 & EP255 & G2 \\
EN121 & G2 & EN282 & nd & EP87 & G7 & EP270 & G3 \\
EN131 & G1 & EN303 & G2 & EP92 & G7 & EP310 & G2 \\
EN132 & G2 & EN306 & G3 & EP95 & G7 & EP330 & nd \\
EN134 & G9 & EN345 & G2 & EP98 & G10 & EP369 & G7 \\
\hline
\end{tabular}

${ }^{*}$ nd - não determinado

\subsubsection{Análise da diversidade genética de bactérias endofíticas e epifíticas de soja}

Com o objetivo de avaliar a diversidade genética entre isolados bacterianos endofíticos e epifíticos a técnica de ARDRA foi utilizada. Foram analisadas 115 linhagens endofíticas (EN) e 62 linhagens epifíticas (EP), incluindo linhagens que apresentaram a capacidade de produzir auxina e solubilizar fosfato inorgânico. A amplificação do 16S rDNA com primers 
universais para bactérias produziu uma banda única em torno de 1350 pb para todas as linhagens testadas, mostrando não haver polimorfismo nesta característica. Os produtos de PCR foram clivados com as enzimas de restrição Mbol, Alul e Haelll e fragmentos com tamanho variando entre 100 e 1000 pb foram considerados na presente análise.

De acordo com o padrão de clivagem, foi possível observar 3 a 5 fragmentos por enzima de restrição, com 12 perfis para a enzima Mbol, 12 para Alul e 14 para HaellI. A combinação dos padrões de restrição (Figura 7) permitiu a distinção de 43 haplótipos (Tabela 3), distribuídos entre os diferentes grupos bacterianos observados. Além disso, foi possível observar que os grupos G3 e G7, ambos representantes da família Enterobacteriaceae, foram os que apresentaram maior diversidade de haplótipos, sendo seguidos pelos grupos G2, G5 (Psedomonadaceae) e G11 ( $\alpha$-Proteobacteria).

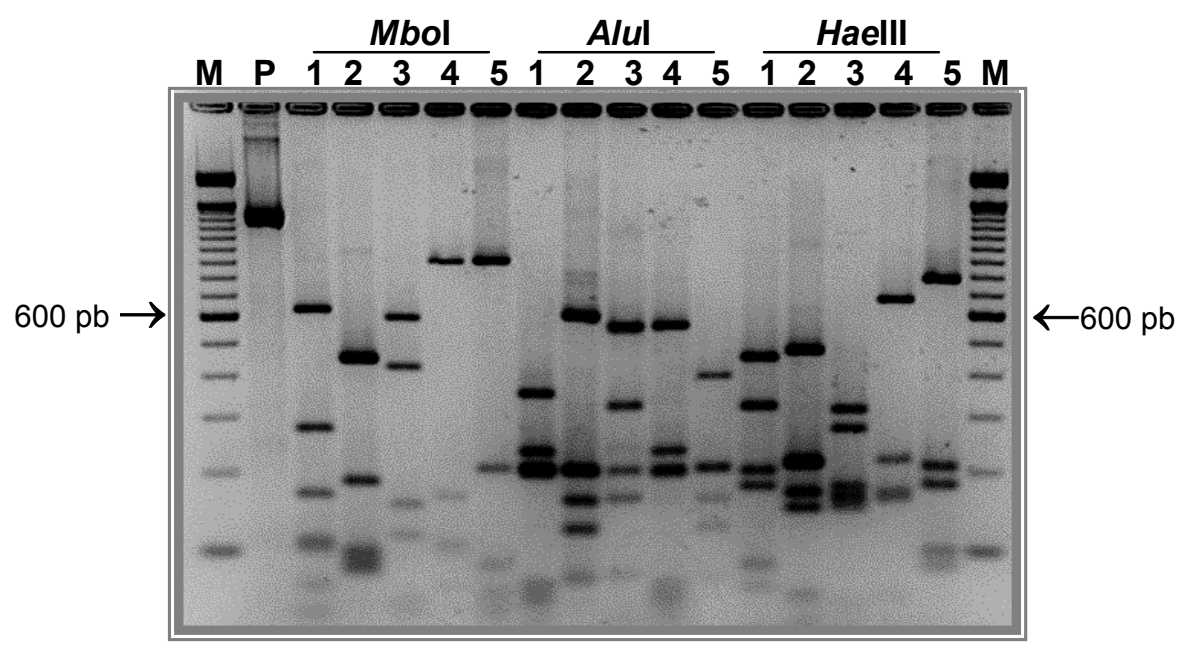

Figura 7 - Exemplos de alguns perfis de restrição do 16S rDNA de bactérias endofíticas e epifíticas de soja, utilizando as enzimas Mbol, Alul e HaellI. P) Fragmento amplificado de 16S rDNA não clivado; M) Marcador DNA Ladder 100 pb (Invitrogen); 1 a 5) Diferentes perfis de restrição 
A Figura 8 mostra a freqüência total dos 43 haplótipos observados pela análise de restrição do $16 \mathrm{~S}$ rDNA das bactérias endofíticas e epifíticas. Os haplótipos B, E e M apresentaram alta freqüência entre os isolados e estiveram presentes em bactérias endofíticas e epifíticas oriundas de todos os diferentes tratamentos considerados (Figura 9), ou seja, solo com e sem aplicação do glifosato em pré-plantio, genótipos do hospedeiro, estádios de desenvolvimento vegetal e tecidos da planta. Foi observada também maior diversidade entre os isolados endofíticos, pois estes apresentaram 32 haplótipos diferentes, sendo 19 haplótipos exclusivos, enquanto que os isolados epifíticos apresentaram 23 haplótipos diferentes com 11 exclusivos (Figura 9).

Tabela 3. Haplótipos observados e suas respectivas combinações de perfis de restrição das enzimas $\mathrm{Mbol}$, Alul e Haelll

\begin{tabular}{|c|c|c|c|c|c|c|c|c|c|}
\hline \multirow[b]{2}{*}{ Grupo } & \multirow[b]{2}{*}{ Haplótipo } & \multicolumn{3}{|c|}{ Perfil de Restrição } & \multirow[b]{2}{*}{ Grupo } & \multirow[b]{2}{*}{ Haplótipo } & \multicolumn{3}{|c|}{ Perfil de Restrição } \\
\hline & & Mbol & Alul & Haelll & & & Mbol & Alul & Haelll \\
\hline G1 & $\mathrm{X}$ & 5 & 1 & 5 & G7 & $M$ & 6 & 7 & 6 \\
\hline G1 & D1 & 1 & 1 & 12 & G7 & $\mathrm{N}$ & 6 & 7 & 8 \\
\hline G2 & $\mathrm{B}$ & 2 & 2 & 2 & G7 & $\mathrm{R}$ & 6 & 7 & 10 \\
\hline G2 & U & 9 & 2 & 4 & G7 & S & 7 & 7 & 6 \\
\hline G2 & V & 10 & 2 & 2 & G7 & G1 & 6 & 7 & 9 \\
\hline G2 & P1 & 9 & 2 & 2 & G7 & N1 & 3 & 7 & 6 \\
\hline G3 & $E$ & 3 & 3 & 3 & G7 & $\mathrm{T} 1$ & 6 & 7 & 14 \\
\hline G3 & $G$ & 6 & 3 & 6 & G8 & 0 & 1 & 8 & 8 \\
\hline G3 & $\mathrm{H}$ & 6 & 3 & 8 & G8 & $\mathrm{A} 1$ & 12 & 8 & 11 \\
\hline G3 & I & 7 & 3 & 6 & G8 & M1 & 12 & 8 & 13 \\
\hline G3 & $\mathrm{J}$ & 3 & 3 & 10 & G9 & $\mathrm{P}$ & 6 & 9 & 8 \\
\hline G3 & $Q$ & 8 & 3 & 3 & G10 & Z & 11 & 10 & 4 \\
\hline G3 & $\mathrm{T}$ & 8 & 3 & 8 & G10 & C1 & 2 & 10 & 2 \\
\hline G3 & E1 & 10 & 3 & 6 & G11 & L1 & 11 & 11 & 2 \\
\hline G4 & $C$ & 4 & 4 & 1 & G11 & O1 & 11 & 11 & 7 \\
\hline G5 & $F$ & 5 & 5 & 4 & G11 & Q1 & 5 & 11 & * \\
\hline G5 & $\mathrm{F} 1$ & 4 & 5 & 5 & G11 & $\mathrm{S} 1$ & 11 & 11 & 1 \\
\hline G5 & K1 & 11 & 5 & 5 & $\mathbf{n d}^{* *}$ & B1 & 6 & 7 & 13 \\
\hline G5 & R1 & 11 & 5 & 4 & $\mathbf{n d}^{* *}$ & $\mathrm{H} 1$ & 2 & 12 & 2 \\
\hline G6 & $D$ & 5 & 6 & 5 & $\mathrm{nd}^{* *}$ & $\mid 1$ & 5 & 1 & 14 \\
\hline G7 & $\mathrm{K}$ & 8 & 7 & 9 & $\mathbf{n d}^{* *}$ & J1 & 2 & 6 & 2 \\
\hline G7 & $\mathrm{L}$ & 7 & 7 & 8 & & & & & \\
\hline
\end{tabular}

* sem corte; ** Não determinado 


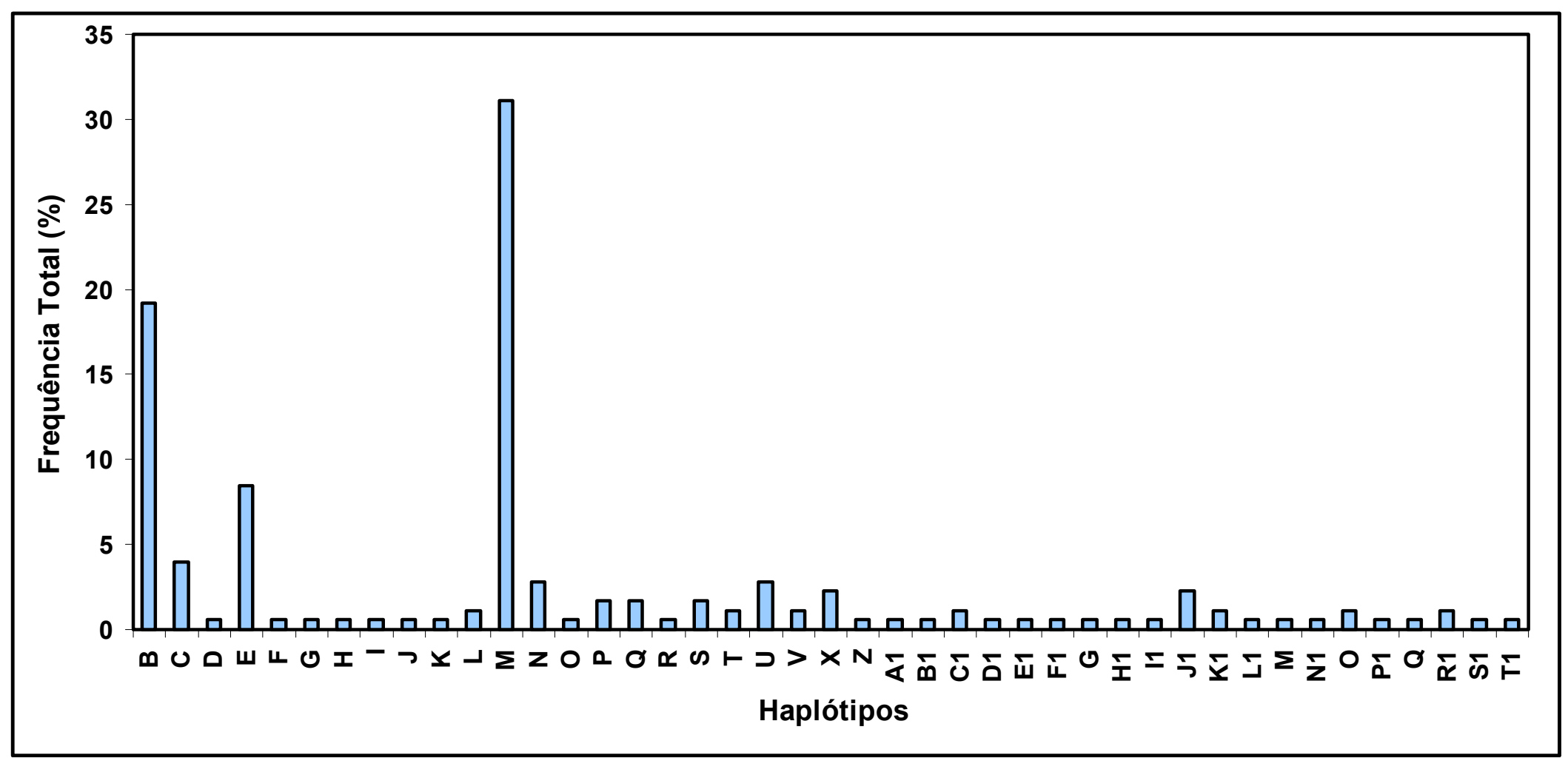

Figura 8 - Freqüência geral dos 43 haplótipos obtidos pela análise de restrição do 16S rDNA com as enzimas Mbol, Alul e Haell das 177 bactérias isoladas de soja 


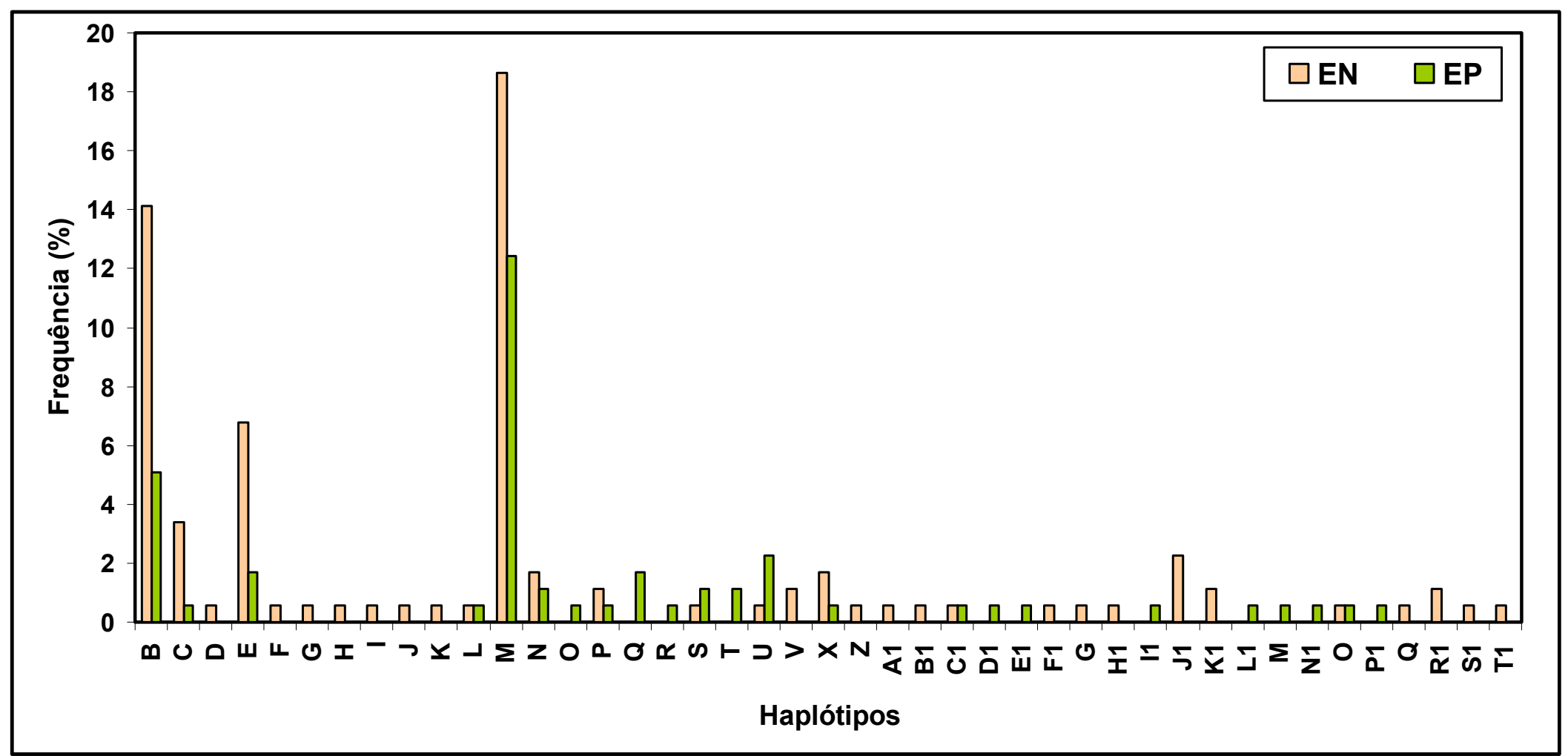

Figura 9 - Freqüência dos 43 haplótipos obtidos pela análise de restrição do 16S rDNA com as enzimas Mbol, Alul e Haelll das 115 bactérias endofíticas e 62 bactérias epifíticas isoladas de soja 
A análise do total de haplótipos permitiu observar que houve diferença quanto à diversidade de haplótipos das populações analisadas em relação aos tratamentos. As bactérias isoladas de plantas cultivadas em solo com aplicação pré-plantio do herbicida glifosato apresentaram maior número de haplótipos diferentes e também de haplótipos exclusivos (Tabela 4). Este fato foi observado também com a microbiota oriunda da cultivar Cristalina, que apresentou maior número de haplótipos que a microbiota da cultivar Foscarin (Tabela 4). Além disso, foi possível observar que bactérias provenientes de plantas em fase R2 (florescimento) ou de raízes apresentaram maior diversidade e haplótipos exclusivos (Tabela 5).

$A$ análise da dinâmica dos haplótipos $B, E$ e $M$, os mais freqüentes, foi realizada em relação aos diferentes tratamentos. Estes genótipos foram encontrados em maior freqüência na população endofítica isolada de plantas que foram cultivadas em solo sem a aplicação do herbicida glifosato, sendo o contrário observado para a população epifítica, ou seja, maior freqüência dos haplótipos $B$ e $M$ em bactérias oriundas de plantas cultivadas em solo com aplicação do glifosato. (Figura 10). Em relação ao genótipo do hospedeiro, é interessante ressaltar que bactérias endofíticas e epifíticas isoladas da cultivar Cristalina apresentaram maior freqüência do haplótipo $M$ (mais de $30 \%$ ), entretanto, os haplótipos $B$ e $E$ foram mais freqüentes apenas em bactérias epifíticas provenientes da cultivar Foscarin (Figura 11).

Tabela 4. Número de haplótipos observados nas populações bacterianas associadas à soja. Tratamentos considerados: solo (com e sem aplicação pré-plantio de herbicida glifosato) e cultivar

\begin{tabular}{|c|c|c|c|c|}
\hline & \multicolumn{2}{|c|}{$\begin{array}{c}\text { Tratamento Pré-Plantio do } \\
\text { Solo }\end{array}$} & \multicolumn{2}{|c|}{ Cultivar } \\
\hline & Com Glifosato & Sem Glifosato & Foscarin & Cristalina \\
\hline No de Haplótipos & 31 & 24 & 27 & 29 \\
\hline $\begin{array}{l}\text { Haplótipos } \\
\text { Exclusivos }\end{array}$ & 16 & 12 & 11 & 15 \\
\hline
\end{tabular}


Tabela 5. Número de haplótipos observados nas populações bacterianas associadas à soja. Tratamentos considerados: estádios de desenvolvimento do hospedeiro e tecidos vegetais

\begin{tabular}{lccccccc}
\hline & \multicolumn{3}{c}{$\begin{array}{c}\text { Estádios de } \\
\text { Desenvolvimento }\end{array}$} & \multicolumn{3}{c}{ Tecidos Vegetais } \\
\cline { 2 - 7 } & V6 & R2 & R6 & Folha & Caule & Raiz \\
\hline $\mathbf{N}^{\circ}$ de Haplótipos & 17 & 24 & 17 & 16 & 23 & 21 \\
Haplótipos Exclusivos & 7 & 15 & 10 & 6 & 10 & 14 \\
\hline
\end{tabular}

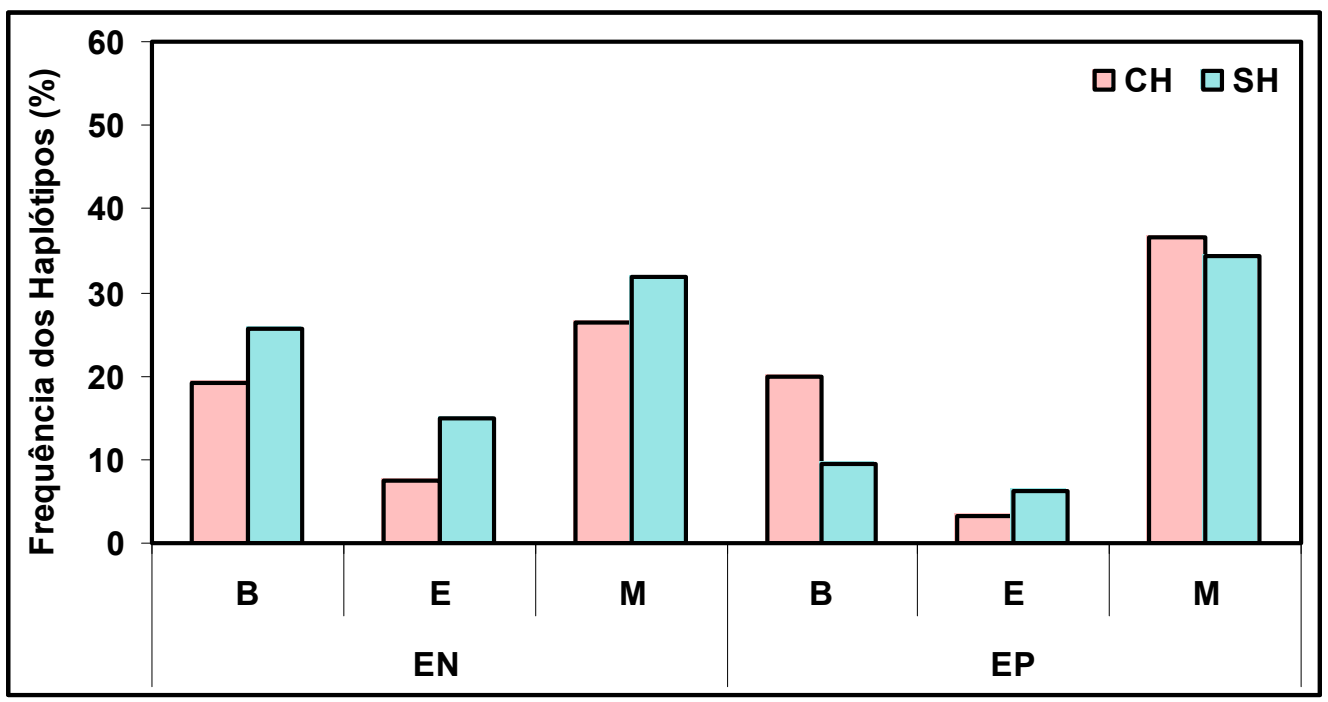

Figura 10 - Freqüência dos haplótipos B, E e M nas populações bacterianas endofíticas (EN) e epifíticas (EP) em relação ao tratamento do solo: com aplicação pré-plantio do herbicida glifosato $(\mathrm{CH})$ e sem aplicação do herbicida (SH) 


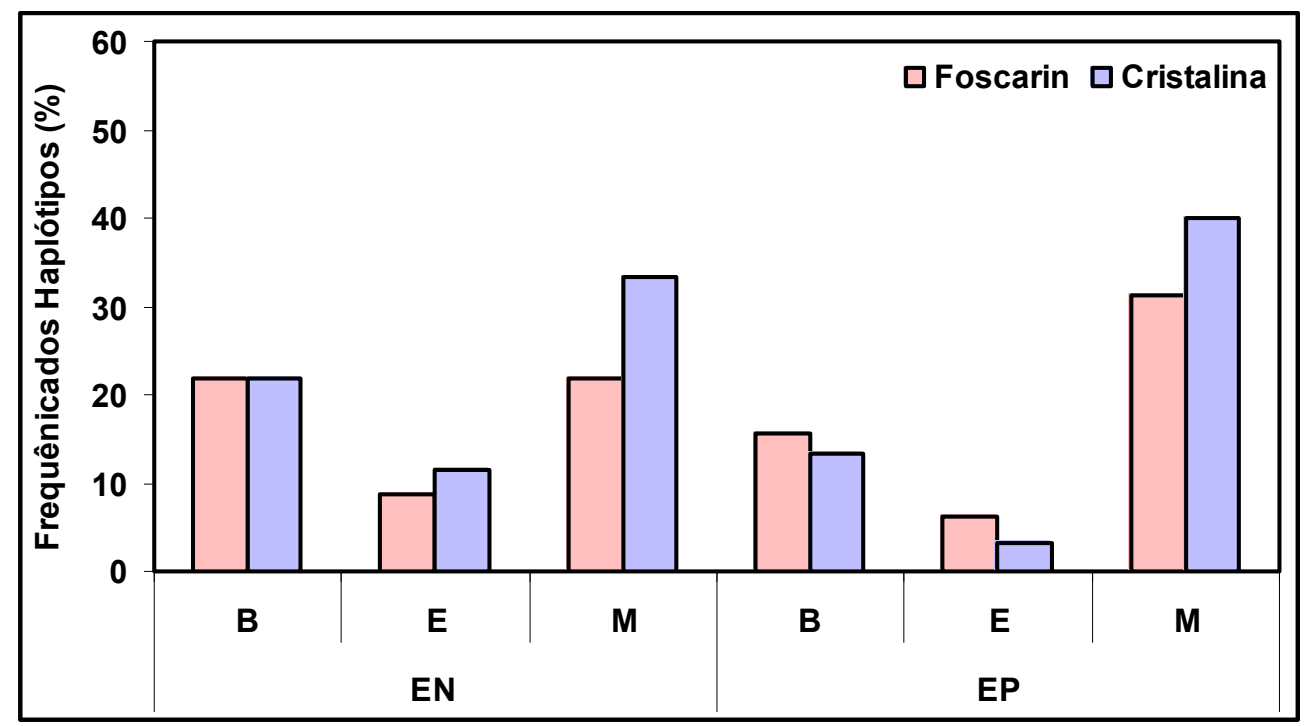

Figura 11 - Freqüência dos haplótipos B, E e M nas populações bacterianas endofíticas (EN) e epifíticas (EP) em relação ao genótipo do hospedeiro: cultivar Foscarin e cultivar Cristalina

O haplótipo $\mathrm{M}$ manteve um equilíbrio em relação aos estádios de desenvolvimento do hospedeiro na população endofítica, mas apresentou maior freqüência durante a fase vegetativa (V6) na população epifítica (Figura 12). Além disso, foi observado que o haplótipo $B$ foi mais freqüente na população endofítica e epifítica, nas fases R6 (maturação) e R2 (florescimento), respectivamente (Figura 12). Em relação aos tecidos vegetais, a freqüência dos haplótipos B e E na população endofítica diminuiu no sentido folha>caule>raiz, enquanto que na população epifítica estes haplótipos estiveram ausentes nas amostras provenientes das raízes. $O$ haplótipo $M$ foi mais freqüente nas bactérias endofíticas e epifíticas isoladas de raízes (Figura 13). 


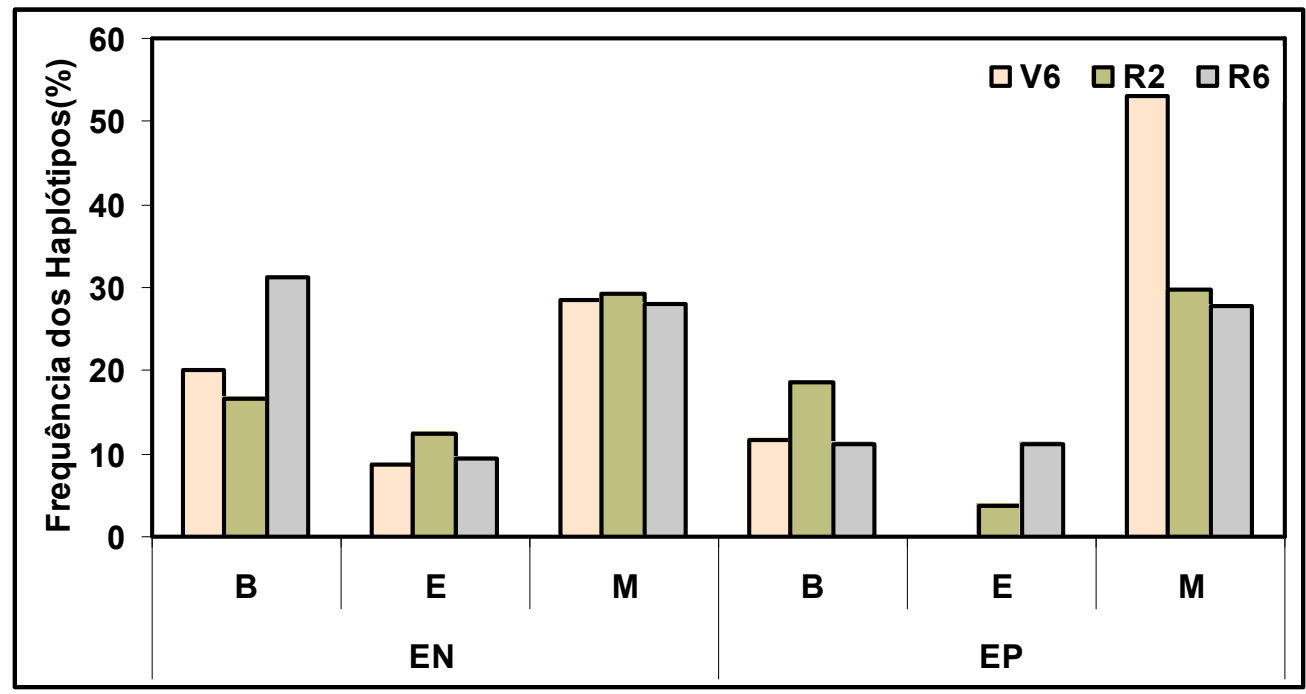

Figura 12 - Freqüência dos haplótipos B, E e M nas populações bacterianas endofíticas (EN) e epifíticas (EP) em relação ao estádio de desenvolvimento do hospedeiro: V6 (vegetativa), R2 (florescimento) e R6 (maturação)

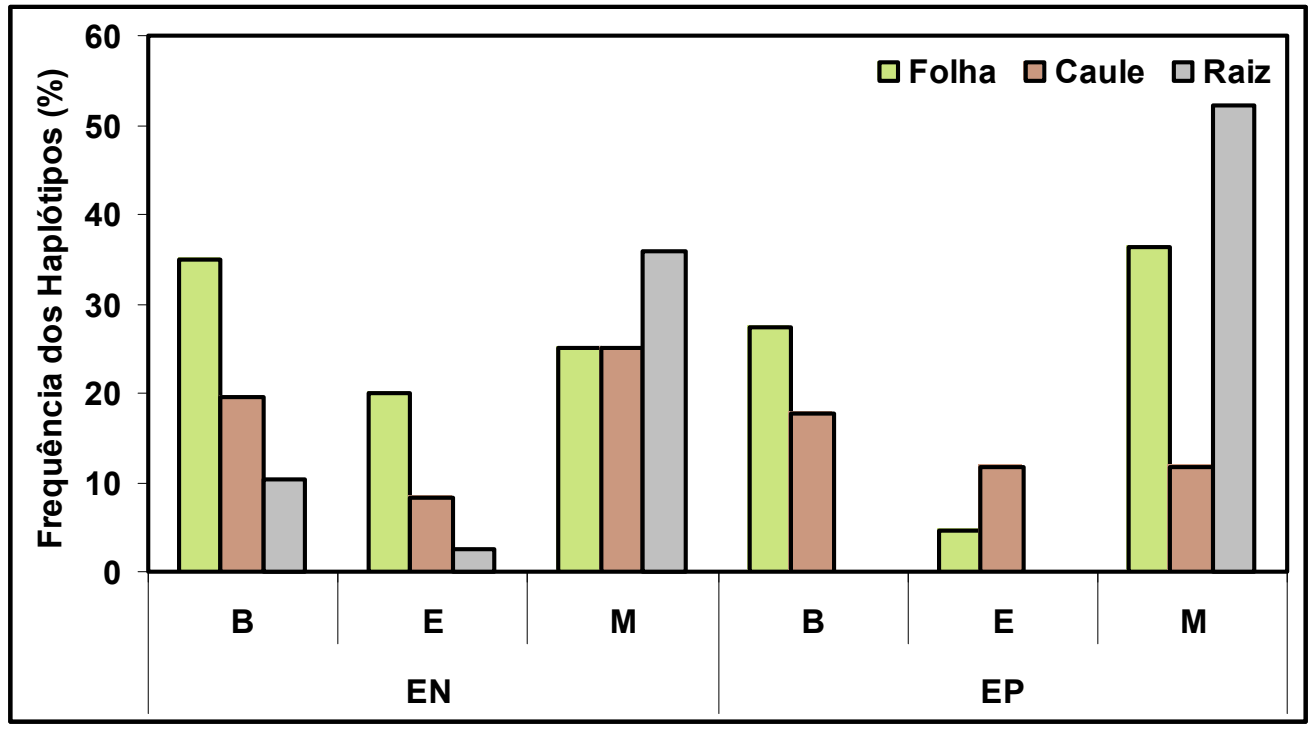

Figura 13 - Freqüência dos haplótipos B, E e M nas populações bacterianas endofíticas (EN) e epifíticas (EP) em relação ao tecido vegetal: Folha, Caule e Raiz 


\subsubsection{Avaliação de promoção de crescimento vegetal por bactérias endofíticas}

Os resultados de produção de auxina, solubilização de fosfato e fixação de $\mathrm{N}_{2}$ permitiram a seleção de 7 isolados endofíticos para serem reintroduzidos em sementes e avaliado o seu papel no desenvolvimento de plântulas de soja. As características de cada endófito estão apresentadas na Tabela 6.

O peso fresco e o peso seco da raiz (Figura 14) e da parte aérea (Figura 15) das plântulas foram avaliados após 17 dias da semeadura, período em que as mesmas estavam em fase de desenvolvimento V3. Foi observado que três bactérias endofíticas, EN263 ( $R$. pickettii), EN268 e EN345 ( $P$. oryzihabitans) promoveram aumento do peso fresco e seco da raiz e, que o isolado EN195 (Pantoea sp.) foi capaz de aumentar somente o peso seco da raiz (Figura 14).

Tabela 6. Características das bactérias endofíticas utilizadas no experimento de promoção de crescimento vegetal (reinoculação via semente)

\begin{tabular}{|c|c|c|c|}
\hline Isolado & Identificação & Haplótipo & Características \\
\hline EN195 & $\begin{array}{l}\text { Pantoea sp. } \\
\text { (G3) }\end{array}$ & $E$ & $\begin{array}{l}\text { Produtor de auxina e solubilizador de } \\
\text { fosfato inorgânico. }\end{array}$ \\
\hline EN230 & $\begin{array}{l}\text { Pseudomonas } \\
\text { sp. } \\
\text { (G10) }\end{array}$ & C1 & $\begin{array}{l}\text { Produtor de auxina, solubilizador de } \\
\text { fosfato inorgânico e fixador de } \mathrm{N}_{2} \text {. }\end{array}$ \\
\hline EN263 & $\begin{array}{l}\text { Ralstonia pickettii } \\
\text { (G6) }\end{array}$ & D & Solubilizador de fosfato inorgânico. \\
\hline EN268 & $\begin{array}{l}\text { P. oryzihabitans } \\
\text { (G2) }\end{array}$ & B & $\begin{array}{l}\text { Produtor de auxina, solubilizador de } \\
\text { fosfato inorgânico e fixador de } \mathrm{N}_{2} \text {. }\end{array}$ \\
\hline EN303 & $\begin{array}{l}\text { P. oryzihabitans } \\
\text { (G2) }\end{array}$ & B & $\begin{array}{l}\text { Produtor de auxina, solubilizador de } \\
\text { fosfato inorgânico e fixador de } \mathrm{N}_{2} \text {. }\end{array}$ \\
\hline EN306 & $\begin{array}{l}\text { Pantoea sp. } \\
\text { (G3) }\end{array}$ & $\mathrm{E}$ & $\begin{array}{l}\text { Produtor de auxina, solubilizador de } \\
\text { fosfato inorgânico e fixador de } \mathrm{N}_{2} \text {. }\end{array}$ \\
\hline EN345 & $\begin{array}{l}\text { P. oryzihabitans } \\
\text { (G2) }\end{array}$ & B & $\begin{array}{l}\text { Produtor de auxina, solubilizador de } \\
\text { fosfato inorgânico e fixador de } \mathrm{N}_{2} \text {. }\end{array}$ \\
\hline
\end{tabular}



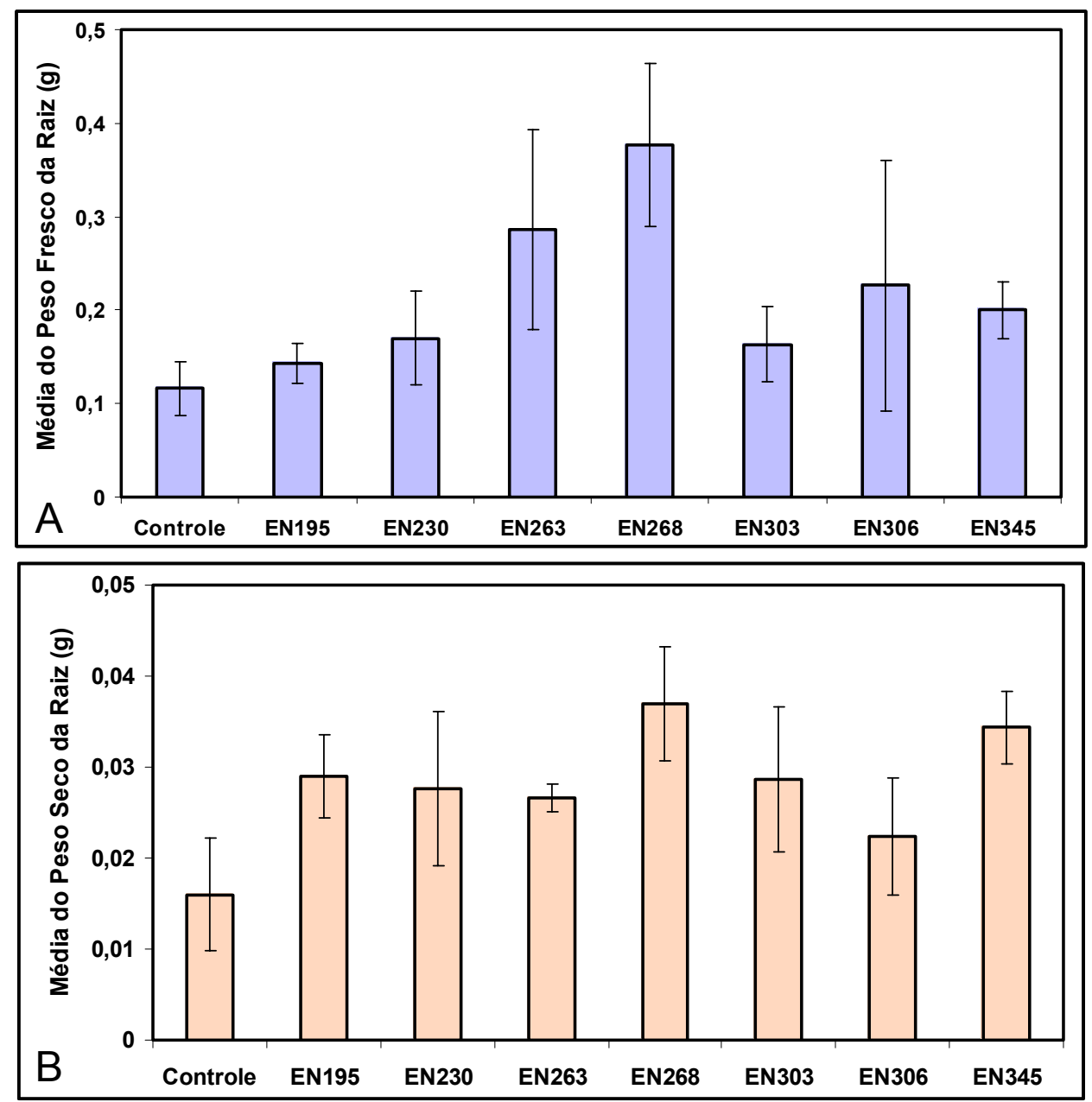

Figura 14 - Peso fresco (A) e peso seco (B) de raiz de plântulas de soja após 17 dias de reintrodução das bactérias endofíticas (via semente)

A análise do peso fresco e seco da parte aérea das plântulas revelou que os isolados EN306 (Pantoea sp.) e EN345 ( $P$. oryzihabitans) apresentaram um efeito significativo sobre esta região da soja (Figura 15). Contudo, apenas o isolado EN345, que produz auxina, solubiliza fosfato e fixa $\mathrm{N}_{2}$, promoveu aumento no peso dos tecidos radiculares e no crescimento da parte aérea das plântulas analisadas. Os resultados possibilitaram também a observação que bactérias com $\mathrm{O}$ mesmo haplótipo interagem de forma diferente com $\mathrm{O}$ hospedeiro, como por exemplo, dos três isolados de haplótipo B empregados, 
dois promoveram o crescimento vegetal (EN268 e EN345) enquanto que o isolado EN303 não apresentou efeito significativo sobre as plântulas.
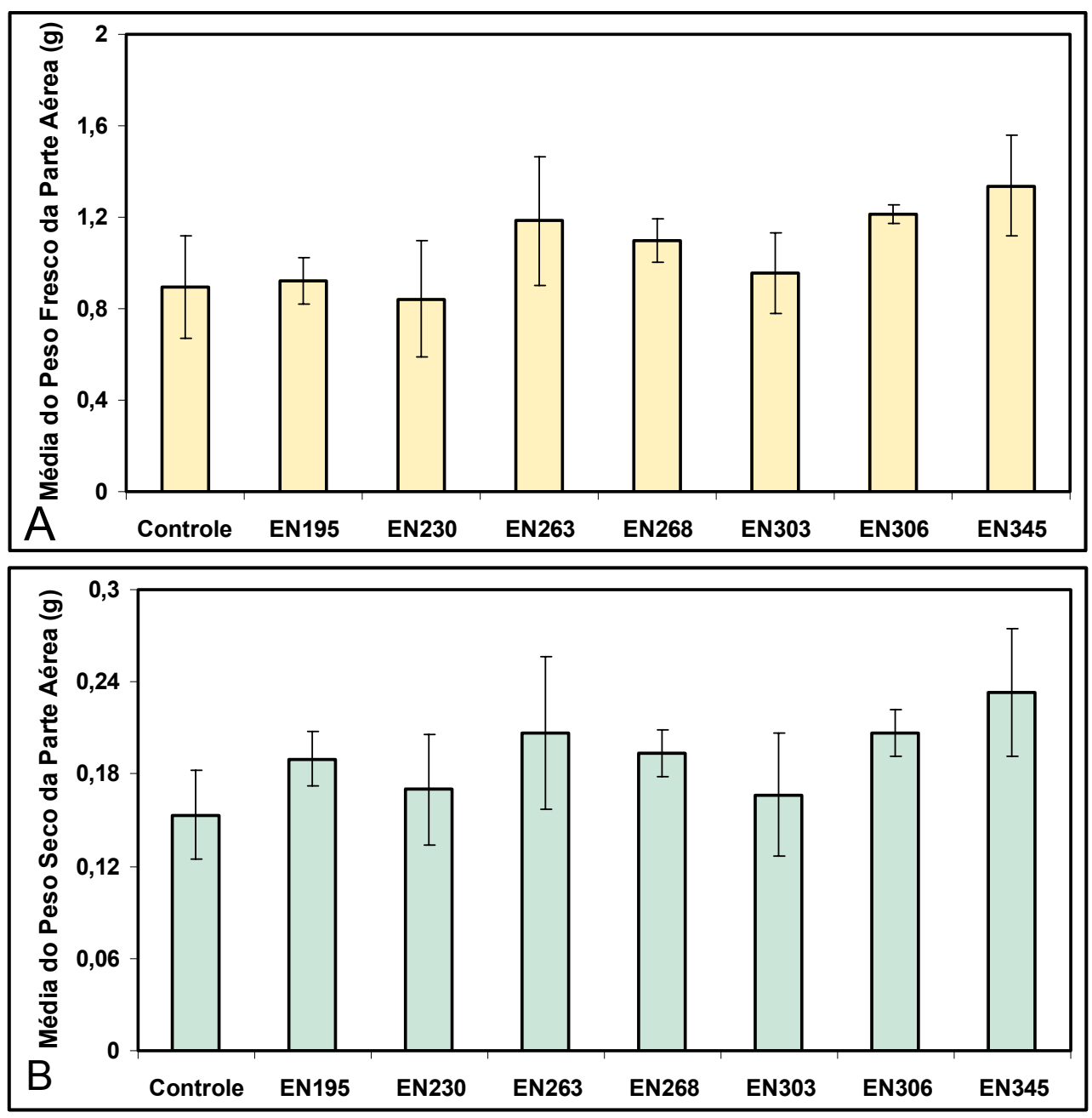

Figura 15 - Peso fresco (A) e peso seco (B) da parte aérea de plântulas de soja após 17 dias de reintrodução das bactérias endofíticas (via semente) 


\subsection{Discussão}

A interação bactéria-planta envolve vários mecanismos associados à planta e/ou aos microrganismos e o conhecimento destes processos pode permitir a exploração desta interação para aumento de produtividade agrícola e/ou interesses industriais, além de fornecer informações para um melhor entendimento da ecologia microbiana e ambiental. Neste contexto, a produção de reguladores de crescimento vegetal (ou fitohormônios) tem um papel importante, pois estes fitohormônios podem favorecer o crescimento ou alterar mecanismos fisiológicos da planta hospedeira, favorecendo a colonização desta por alguns microrganismos em detrimento de outros. Com o objetivo de avaliar a possível produção de reguladores de crescimento vegetal por bactérias, em especial o ácido indol acético (AIA) que é um fitohormônio do grupo das auxinas, Bric et al. (1991) desenvolveram uma metodologia de seleção qualitativa de bactérias produtoras de auxina. Esta metodologia se baseia no fato de que o triptofano é o precursor para a síntese de AIA, portanto, a presença deste aminoácido no meio de cultura conduz ao estímulo da síntese de auxina pelas bactérias e, como resultado, este fitohormônio apresenta a capacidade de interagir com o reagente de Salkowski (Ehmann, 1977) resultando numa coloração rosa. A utilização desta metodologia, no presente trabalho, foi eficiente para a seleção em larga escala de bactérias endofíticas e epifíticas de soja produtoras de AIA, auxiliando o estudo da interação bactériaplanta.

O grupo Proteobacteria prevaleceu nas comunidades bacterianas endofíticas e epifíticas e sua subdivisão gama foi a mais freqüente e com maior diversidade. Este grupo também foi o mais freqüente em Lolium perenne, Trifolium repens (Marilley e Aragno, 1999) e em milho (Chelius e Triplett, 2001). Além da diversidade genética, este grupo bacteriano apresentou diversidade fisiológica entre as características com potencial para promoção de crescimento vegetal avaliadas. Neste estudo, a diversidade fisiológica parece estar 
relacionada ao genótipo do hospedeiro, demonstrando que características da planta e dos microrganismos estão envolvidas na interação bactéria-planta. Por exemplo, a cultivar Foscarin, que apresenta ciclo precoce, apresentou porcentagem mais alta de bactérias epifíticas produtoras de auxina que a cultivar Cristalina (ciclo tardio). Alguma especulação pode ser feita sobre o papel desta comunidade bacteriana produtora de auxina sobre a precocidade desta cultivar, visto que estas plantas apresentaram maior população de bactérias produtoras de AIA, um fitohormônio que atua na diferenciação celular vegetal e no crescimento radicular (Arshad \& Frakenberger-Jr, 1998), e que não funciona aparentemente como um hormônio em células bacterianas. Entretanto, esta auxina bacteriana estimula o desenvolvimento do sistema radicular da planta hospedeira (Glick, 1995; Patten \& Glick, 1996; Bastian et al., 1998; Dobbelaere et al., 1999; Verma et al., 2001 Patten \& Glick, 2002), sugerindo um importante papel na interação bactéria-planta.

Além da produção de fitohormônios, a capacidade de bactérias em solubilizar fosfato inorgânico também é um fator envolvido na interação bactéria-planta, pois esta característica aumenta a disponibilidade de fosfato viável para o vegetal, sendo este um possível mecanismo de promoção de crescimento vegetal em condições de campo (Rodriguez \& Fraga, 1999). Neste aspecto, a observação de maior freqüência de bactérias endofíticas solubilizadoras de fosfato inorgânico durante o estádio fenológico V6 da soja (fase vegetativa), sugere que este grupo de bactérias poderia ter um papel mais importante durante esta fase do desenvolvimento da planta hospedeira. Tendo em vista que bactérias endofíticas colonizam o interior da planta hospedeira e o fosfato inorgânico está no solo, é viável especular que bactérias endofíticas, durante seu processo de colonização da planta, podem solubilizar e aumentar a disponibilidade de fosfato à planta hospedeira.

Entre os isolados endofíticos e epifíticos com capacidade de produzir auxina e solubilizar fosfato inorgânico, foram encontradas as seguintes 
espécies: Pantoea sp., Pseudomonas oryzihabitans, Acinetocbater sp., Enterobacter sp., Agrobacterium sp., Ralstonia picketti e Burkholderia sp. Estudos anteriores já demonstraram que espécies dos gêneros Pseudomonas, Burkholderia e Pantoea apresentam a capacidade de promover o crescimento vegetal por diferentes mecanismos, inclusive produzindo auxinas e solubilizando fosfato (Patten \& Glick, 1996; Sturz et al., 1998; Lambrecht et al., 2000; Belimov et al., 2001; Verma et al., 2001), mas até o presente momento não havia sido avaliada esta população em soja. Além disso, o fato de que a população de bactérias endofíticas apresentou um percentual maior de isolados potencialmente promotores de crescimento, em relação às duas características citadas, sugere que estas bactérias devem interagir com a planta hospedeira de forma diferente daquela apresentada pelas bactérias epifíticas, sendo este um mecanismo que deve ser melhor explorado.

A fixação biológica de $\mathrm{N}_{2}$ tem sido um dos mecanismos envolvidos na interação microrganismos-planta mais estudados (Dobereiner et al., 1995; Egener et al., 1999; Chleius \& Tripplet, 2000; Reis et al., 2000; Cocking, 2003), enquanto que na interação bactéria-soja o mais investigado é o sistema de nodulação e interação com Bradyrhizobium (Polenko et al., 1987; Dobereiner, 1992; Dobereiner et al., 1995; Oehrle et al., 2000; Bai et al., 2002, Bai et al., 2003). Biofertilizantes aumentam a produção de culturas agrícolas pelas combinações de fixação biológica de $\mathrm{N}_{2}$ (FBN), substâncias que promovem o crescimento vegetal (fitohormônios), maior disponibilidade nutrientes no solo e controle de doenças (Cocking, 2003). Desde que o nitrogênio atmosférico é uma fonte renovável, a FBN é uma fonte sustentável de $\mathrm{N}_{2}$ em sistemas agrícolas (Jensen \& Hauggaard-Nielsen, 2003). Mantendo isto em foco, a fixação de $\mathrm{N}_{2}$ foi avaliada em bactérias produtoras de AIA e solubilizadoras de fosfato inorgânico, sendo observado alta porcentagem destas bactérias com capacidade de fixação de $\mathrm{N}_{2}$. Entretanto, foi observada alta discrepância entre a proporção de isolados bacterianos com capacidade de crescer em meio de cultura livre de nitrogênio e isolados que apresentaram reação de PCR positiva 
para o gene nifH. Este resultado pode ser explicado pelo fato deste gene apresentar diferentes seqüências de nucleotídeos entre e dentre diferentes espécies microbianas (Zehr et al., 2003). Portanto, as bactérias associadas à soja que foram capazes de fixar $\mathrm{N}_{2}$ in vitro e não apresentaram o fragmento esperado na reação de PCR podem possuir seqüências diferentes daquelas amplificadas com os primers descritos por Ueda et al. (1995).

O estudo da diversidade funcional de comunidades microbianas associadas às plantas pode ser enriquecido com o conhecimento da estrutura e diversidade genética das populações bacterianas avaliadas. Contudo, o estudo da estrutura genética de comunidades microbianas associadas às plantas, em especial a soja, é importante para o entendimento de seu papel ecológico, ou seja, como estas comunidades respondem as mudanças ambientais e o seu papel na interação microrganismos-planta. Neste aspecto, os genes que codificam as subunidades ribossomais são freqüentemente utilizados para estudos filogenéticos e de diversidade microbiana, especificamente as seqüências de $16 \mathrm{~S}$ rDNA, pois, estas contêm regiões altamente conservadas e também regiões variáveis (Hunter-Cevera, 1998; Van Elsas et al., 1998). O ARDRA tem sido utilizado para estudos de diversidade microbiana associada a vegetais ou a diferentes solos (Ovreas \& Torsvik, 1998; Chelius \& Triplett, 2001), bactérias degradadoras de pesticidas (Desaint et al., 2000); caracterização de bactérias diazotróficas (Cruz et al., 2001) e inclusive alterações causadas por pesticidas em populações bacterianas de solo (Crecchio et al., 2001).

Portanto, foi possível avaliar a diversidade genética da comunidade bacteriana endofítica e epifítica com potencial para promoção de crescimento vegetal e observar interações entre os genótipos bacterianos e diferentes fatores ambientais por meio da análise de ARDRA. Alguns haplótipos foram detectados tanto em bactérias isoladas da superfície quanto do interior da planta, sugerindo que populações bacterianas podem flutuar entre o estado 
endofítico e epifítico, ou seja, bactérias epifíticas possuem a capacidade de penetrar e colonizar a planta e se estabelecer endofiticamente, mostrando que podem ser utilizadas para o controle de patógenos sistêmicos e/ou que colonizam a superfície dos tecidos da planta hospedeira (Hallmann et al., 1997b; Azevedo, 1998a; Azevedo et al., 2000b; Andrews \& Harris, 2000), além de poderem ser utilizados como potenciais biofertilizadores.

A análise da diversidade genética de populações endofíticas e epifíticas permitiu observar que fatores como o tratamento do solo com herbicida, estádio fenológico, genótipo e tecido da planta hospedeira podem influenciar a comunidade microbiana associada à soja, aumentando ou diminuindo a diversidade bacteriana. Diversos trabalhos corroboram estas observações em relação a outros hospedeiros (Sturz et al., 1997; Siciliano et al., 1998; Dalmastri et al.; 1999; Cheneby et al., 2000; Fromin et al., 2001; Mocali et al., 2003). Além disso, a dinâmica dos haplótipos B, E e M sugere que, caso ocorra um aumento da aplicação do herbicida glifosato devido à utilização de plantas transgênicas tolerantes a este herbicida, poderá haver alteração na microbiota bacteriana associada à soja, podendo ser esta microbiota potencial promotora de crescimento vegetal. Embora alguns trabalhos tenham relatado que o glifosato apresenta pouca ou nenhuma influência sobre a comunidade microbiana do solo (Nicholson \& Hirsch, 1998; Busse et al., 2001) ou até em fungos endofíticos (Prestige \& Sprosen, 1995), há trabalhos que relatam a toxicidade deste herbicida sobre grupos microbianos (Levesque \& Rahe, 1992; Santos \& Flores, 1995; Dick \& Quinn, 1995). Portanto, estudos devem ser conduzidos para o melhor entendimento desta interação e o seu efeito sobre populações bacterianas.

Foi observado que 5 isolados bacterianos induziram ao aumento do peso seco e fresco da raiz e/ou da parte aérea de plântulas de soja, após inoculação via semente. A linhagem EN263, identificada como $R$. pickettii, apresentou, durante os experimentos, a capacidade de solubilizar fosfato inorgânico. Há resultados que mostram a capacidade desta espécie em 
degradar compostos como tolueno e PCBs (Parales et al., 2000), apresentando, portanto, potencial para ser utilizada em programas de biorremediação. Contudo, de acordo com os dados apresentados no presente trabalho, esta espécie poderia também ser utilizada para a promoção de crescimento vegetal de soja. Já a linhagem EN195 (Pantoea sp.) promoveu um aumento significativo somente do peso seco da raiz indicando que estas plântulas acumularam menos água em relação ao controle, mas produziram mais matéria seca. Embora seja especulativo, pode ser sugerido que estas plantas poderiam apresentar maior/menor tolerância ao estresse hídrico devido à presença destas bactérias endofíticas, ou que estas bactérias poderiam influenciar a capacidade de fotossíntese da planta hospedeira, resultando, como observado, no aumento do peso seco da planta . Além disso, outra linhagem de Pantoea sp. (EN306), juntamente com uma de $P$. oryzihabitans (EN345) foram promotoras do aumento do peso seco e fresco da raiz e parte aérea vegetal, sugerindo serem potenciais candidatas à promoção de crescimento vegetal em campo, pois produzem auxina, solubilizam fosfato e fixam nitrogênio atmosférico. Estes gêneros bacterianos já foram relatados como promotores de crescimento em arroz e canola (Verma et al., 2001; Patten \& Glick, 2002). Portanto, os resultados apresentados revelam que populações bacterianas endofíticas e epifíticas de soja podem apresentar potencial aplicação para a promoção de crescimento vegetal.

\subsection{Conclusões}

Os resultados apresentados permitem concluir que:

a) bactérias endofíticas e epifíticas de soja apresentam potencial para promoção de crescimento vegetal, pois, possuem a capacidade de produzir auxina, solubilizar fosfato inorgânico e fixar $\mathrm{N}_{2}$;

b) a freqüência de bactérias epifíticas produtoras de auxina foi maior em plantas de ciclo precoce (Foscarin); 
c) bactérias endofíticas pertencentes às espécies Pseudomonas oryzihabitans, Ralstonia pickttii e Pantoea sp. promoveram o aumento de peso de raiz e da parte aérea de plântulas de soja, in vitro, apresentando, portanto, potencial aplicação biotecnológica;

d) a diversidade fisiológica e genética de bactérias endofíticas e epifíticas pode ser influenciada pela aplicação (pré-plantio) do herbicida glifosato, fases de crescimento, genótipo e tecidos da soja. 


\section{ISOLAMENTO E CARACTERIZAÇÃO DE BACTÉRIAS ENDOFÍTICAS DE SOJA ASSOCIADAS À DEGRADAÇÃO DO HERBICIDA GLIFOSATO}

\section{Resumo}

Bactérias endofíticas são encontradas na maioria das espécies de plantas, colonizando local ou sistemicamente a planta hospedeira, podendo influenciar o seu desenvolvimento por supressão de doenças, degradação de contaminantes e promoção de crescimento vegetal. Além disso, foram desenvolvidas plantas de soja transgênicas com tolerância ao herbicida glifosato. Visto que bactérias endofíticas são afetadas pelo manejo agrícola, o iminente aumento do uso do herbicida glifosato na cultura da soja poderia alterar a comunidade endofítica neste hospedeiro. O objetivo deste trabalho foi isolar e caracterizar bactérias endofíticas que utilizam glifosato como fonte de carbono, estudar sua diversidade genética, avaliar seu potencial para promoção de crescimento vegetal e definir o perfil de sensibilidade ao glifosato dos grupos endofíticos. Noventa e quatro isolados bacterianos endofíticos com capacidade de utilizar o glifosato como única fonte de carbono foram isolados de folhas, caules e raízes de duas cultivares de soja crescidas em solo com e sem aplicação em pré-plantio do herbicida glifosato, durante diferentes estádios de desenvolvimento vegetal (V6, R2, e R6). Estas bactérias foram identificadas como Burkholderia gladioli e Pseudomonas oryzihabitans, sendo avaliadas por ARDRA, RAPD, e PCR específico para gene de nifH. Este gene foi detectado apenas em $P$. oryzihabitans e alta variabilidade genética foi observada por RAPD dentro de cada grupo. Além disso, os resultados revelaram que o 
tratamento com glifosato, cultivar, estádios de desenvolvimento e tecidos vegetais do hospedeiro podem influenciar a colonização bacteriana endofítica. Finalmente, foi observado que $B$. gladioli é mais tolerante ao glifosato que $P$. oryzihabitans. Estes resultados sugerem que comunidades bacterianas endofíticas de soja com diferente sensibilidade a este herbicida poderiam ser afetadas pelo aumento da aplicação do glifosato. Também, bactérias endofíticas com capacidade de utilizar o glifosato como única fonte de carbono poderiam ter potencial uso na bioremediação de xenobióticos orgânicos e na promoção de crescimento vegetal.

\section{Summary}

Endophytic bacteria are ubiquitous in most plant species, colonizing locally as well as systemically, influencing the host fitness by disease suppression, contaminant degradation, and plant growth promotion. This endophytic bacterial community may be affected by crop managing and the development of transgenic soybean plants, tolerant to glyphosate herbicide, could increase the glyphosate application on soybean crop. The endophytic population could be affected, changing the bacterial equilibrium in plantendophyte interaction. The aim of this work was to isolate and characterize endophytic bacteria that utilize glyphosate as carbon source, study their genetic diversity, evaluate their potential for plant growth promotion, and their sensibility to glyphosate. Ninety four endophytic bacterial strains with inherent ability of utilizing glyphosate as a sole carbon source have been isolated from leaves, stems, and roots of two soybean cultivars that were planted on plots with and without glyphosate herbicide pre-planting. These endophytic bacteria were isolated from plants in growth stages $\mathrm{V} 6, \mathrm{R} 2$, and R6 and further identified as Burkholderia gladioli and Pseudomonas oryzihabitans and characterized by ARDRA, RAPD, and PCR specific for nifH gene. The nifH gene was detected only in $P$. oryzihabitans strains and high genetic variability was detected inside 
each group by RAPD. Furthermore, the results revealed that glyphosate herbicide, soybean cultivar, plant growth stages, and plant tissues may influence the endophytic bacterial colonization. Finally, B. gladioli showed more tolerance to glyphosate herbicide than $P$. oryzihabitans. These results suggest that endophytic bacterial communities from soybean with different glyphosate tolerance could be affected by increase of herbicide application. Also, this microbial community able to use this herbicide as carbon source could play a potential role in bioremediation of organic xenobiotics and plant growth promotion.

\subsection{Introdução}

As plantas podem ser consideradas um microecossistema complexo onde diferentes nichos são explorados por uma extensa variedade de microrganismos. Estes nichos não são apenas representados pela superfície externa das plantas, onde bactérias epifíticas predominam, mas também por tecidos internos, onde bactérias endofíticas penetram e sobrevivem (Azevedo et al., 2000b; Lodewyckx et al., 2002). Bactérias endofíticas, segundo Hallmann et al. (1997b) são aquelas que podem ser isoladas do interior de tecidos vegetais desinfectados superficialmente, e que não causam danos ao hospedeiro. Esta definição inclui relações neutras e simbióticas e, também, inclui bactérias que durante sua fase endofítica flutua entre endofíticas e epifíticas. Estas bactérias são encontradas na maioria das espécies de plantas, colonizando localmente como também sistemicamente (Reinhold-Hurek \& Hurek; 1998; Sturz et al., 2000; Lodewyckx et al., 2002). A interação endófitos-planta é muito complexa, embora, estudos anteriores tenham mostrado o efeito protetor desta comunidade contra patógenos e pragas do hospedeiro (Kloepper et al., 1991; Sturz \& Matheson, 1996; Azevedo et al., 2000a; Reiter et al., 2002) e influenciando o desenvolvimento da planta por promoção de crescimento vegetal (Shishido et al., 1999; Sturz et al., 2000; Verma et al., 2001; Patten \& 
Glick, 2002). Além disso, a fitorremediação de contaminantes orgânicos, baseada na ação combinada entre plantas e microrganismos associados, é uma potencial aplicação desta comunidade endofítica (Siciliano et al., 2001; Lodewyckx et al., 2002).

Durante as últimas décadas, o intensivo uso de herbicidas conduziu a uma crescente preocupação, principalmente devido ao aumento da poluição ambiental. O glifosato é um herbicida muito popular e conhecido por seu efetivo controle de ervas daninhas, rápida inativação no solo e baixa toxicidade em mamíferos (Levesque \& Rahe, 1992; Busse et al., 2001). Apesar do glifosato poder ser degradado por diversos microrganismos, alguns estudos relatam que este herbicida pode ser prejudicial a diferentes grupos microbianos (Levesque \& Rahe, 1992; Santos \& Flores, 1995; Krzysko-Lupicka \& Orlik, 1997). Este herbicida ganhou maior destaque após o desenvolvimento de plantas transgênicas, em especial a soja resistente ao glifosato. Contudo, nenhuma exploração foi realizada sobre o efeito do glifosato na comunidade bacteriana endofítica de soja.

Desta forma, os objetivos do presente trabalho foram: (i) isolar e identificar bactérias endofíticas de soja capazes de crescer em meio de cultura com o herbicida glifosato como única fonte de carbono; (ii) avaliar a possível influência de diferentes fatores (solo com e sem aplicação do herbicida glifosato, estádios de desenvolvimento do hospedeiro, genótipos da planta e tecidos vegetais) sobre esta comunidade bacteriana endofítica; (iii) analisar a variabilidade genética destes endófitos por meio de marcadores ARDRA e RAPD; (vi) detectar a presença do gene nifH em isolados bacterianos endofíticos; e (v) caracterizar o perfil de sensibilidade ao glifosato dos principais grupos bacterianos endofíticos. 


\subsection{Material e Métodos}

\subsubsection{Material vegetal}

Plantas de soja [Glycine max (L.) Merrill] foram cultivadas na área experimental do Campus da Escola Superior de Agricultura "Luiz de Queiroz" USP, Piracicaba/SP $\left(22^{\circ} 42^{\prime}\right.$ S e $\left.47^{\circ} 38^{\prime} \mathrm{W}\right)$, safra de $2000 / 01$. O solo foi submetido à análise no Departamento de Solos e Nutrição de Plantas da ESALQ/USP, sendo classificado como argiloso e apresentando as seguintes características: $\mathrm{pH} \mathrm{5,4} \mathrm{(água),} \mathrm{2,7} \mathrm{mmol/} \mathrm{Kg}$ potássio e 21,1 $\mathrm{mg} / \mathrm{Kg}$ fósforo total. Duas cultivares foram utilizadas, Foscarin (ciclo precoce) e Cristalina (ciclo tardio), sendo crescidas em dois lotes, um com aplicação pré-plantio do herbicida glifosato $(1,44 \mathrm{Kg} / \mathrm{ha}$ Agrisato $480 \mathrm{CS}$ - Alkagro) e outro sem aplicação e histórico do herbicida citado. Cada lote $(2 \times 6 \mathrm{~m})$ apresentou 10 linhas e 15 plantas por linha. Para os isolamentos, 4 plantas de cada cultivar foram coletadas em três estádios de desenvolvimento vegetal (Neumaier et al. 2000): vegetativo (V6); florescimento (R2); e maturação (R6).

\subsubsection{Isolamento de bactérias endofíticas capazes de utilizar glifosato como fonte de carbono}

Bactérias endofíticas com capacidade de utilizar o glifosato como fonte de carbono foram isoladas de folhas, caules e raízes. As amostras de soja foram removidas do solo e levadas em sacos plásticos para o laboratório, no qual foram imediatamente processadas. As plantas foram lavadas em água corrente para a retirada do solo agregado às raízes e separadas em folha, caule e raiz.

Todos os tecidos foram desinfectados superficialmente pelas seguintes etapas: lavagem por $1 \mathrm{~min}$ em etanol $70 \%$; $3 \mathrm{~min}$ em hipoclorito de sódio $(\mathrm{NaOCl})$ a $2 \%$ de cloro ativo $(\mathrm{v} / \mathrm{v})$ acrescido de Tween $20(1 \mathrm{ml} / \mathrm{l})$ e $30 \mathrm{~s} \mathrm{em}$ 
etanol $70 \%$, seguido de duas lavagens em água destilada esterilizada. Os tecidos foram cortados, assepticamente, em pequenos fragmentos e triturados em $10 \mathrm{ml}$ de tampão PBS (1,44 g/l de $\mathrm{Na}_{2} \mathrm{HPO}_{4} ; 0,24 \mathrm{~g} / \mathrm{l}$ de $\mathrm{KH}_{2} \mathrm{PO}_{4} ; 0,20 \mathrm{~g} / \mathrm{l}$ de $\mathrm{KCl} ; 8,00 \mathrm{~g} / \mathrm{l}$ de $\mathrm{NaCl} ; \mathrm{pH} 7,4)$. Todo o material foi transferido para tubos de 15 $\mathrm{ml}$ e incubados sob agitação (150 rpm) a $28^{\circ} \mathrm{C}$ por $1 \mathrm{~h}$. Em seguida foi aplicada a metodologia de enriquecimento, na qual $1 \mathrm{ml}$ da solução foi inoculado em 10 ml de meio mineral líquido DF (Dworkin \& Foster, 1958, modificado: $10 \mu \mathrm{g} / \mathrm{l}$ de $\mathrm{H}_{3} \mathrm{BO}_{3}, 10 \mu \mathrm{g} / \mathrm{l}$ de $\mathrm{MnSO}_{4} .7 \mathrm{H}_{2} \mathrm{O}, 125 \mu \mathrm{g} / \mathrm{l}$ de $\mathrm{ZnSO}_{4} .7 \mathrm{H}_{2} \mathrm{O}, 80 \mu \mathrm{g} / \mathrm{l}$ de $\mathrm{CuSO}_{4} .5 \mathrm{H}_{2} \mathrm{O} ; 17 \mu \mathrm{g} / \mathrm{l}$ de $\mathrm{NaMoO}_{3} .3 \mathrm{H}_{2} \mathrm{O} ; 1 \mathrm{mg} / \mathrm{l}$ de $\mathrm{FeSO}_{4} .7 \mathrm{H}_{2} \mathrm{O} ; 200 \mathrm{mg} / \mathrm{l}$ de $\mathrm{MgSO}_{4} .7 \mathrm{H}_{2} \mathrm{O} ; 2 \mathrm{~g} / \mathrm{l}$ de $\left(\mathrm{NH}_{4}\right)_{2} \mathrm{SO}_{4} ; 16 \mathrm{~g} / \mathrm{l}$ de agar; $\mathrm{pH}$ 7,0) e $20 \mathrm{mM}$ do herbicida glifosato como única fonte de carbono (Agrisato 480 CS - Alkagro). Para confirmar que o processo de desinfecção foi bem sucedido, alíquotas da água destilada utilizada na última lavagem foram semeadas em TSA 10\% (Trypcase Soy Agar) e incubadas a $28^{\circ} \mathrm{C}$ por $4-15$ dias. O material foi incubado a $28^{\circ} \mathrm{C}$ sob agitação (150 rpm), por 10 dias para o crescimento bacteriano. Após este período, esta solução foi transferida para um novo meio DF $(1 \mathrm{ml}$ de solução : 9 $\mathrm{ml}$ do meio DF) e mantido nas condições descritas. Este procedimento foi repetido mais 2 vezes. Diluições apropriadas do material enriquecido foram semeadas em meio sólido DF suplementado com $20 \mathrm{mM}$ de glifosato e incubados a $28^{\circ} \mathrm{C}$ por 20 dias. Por fim, bactérias cultiváveis nas condições utilizadas foram isoladas, purificadas e estocadas em TSA $10 \%$ suplementado com $20 \%$ de glicerol a $-70^{\circ} \mathrm{C}$ para posterior análise.

\subsubsection{Identificação dos isolados bacterianos}

Os isolados bacterianos foram agrupados por características morfológicas e por riboptipagem, sendo que isolados representativos de cada grupo foram enviados ao "Bacteria Collection Laboratorium voor Microbiologie Universiteit Ghent - Belgium" para identificação por análise de ácidos graxos totais da célula bacteriana (FAME - Fatty Acid Methyl Esters), feitas por 
cromatografia e pelo sistema MIDI (Microbial Identification System, Inc., Delaware, USA). Os isolados que não puderam ser identificados por FAME foram ensaiados por BIOLOG (Biolog Inc., California, USA) ou utilizando o perfil de índice analítico (API - AP 20E e AP50CHE. Bio Mérieux S.A., France).

\subsubsection{Extração de DNA genômico de bactérias}

As linhagens foram cultivadas em $5 \mathrm{ml}$ de TSA $10 \%$ líquido por $24 \mathrm{~h}$ a $28^{\circ} \mathrm{C}$ sob agitação de $150 \mathrm{rpm}$. Dois a $4 \mathrm{ml}$ da cultura foram centrifugados por 5 min a $14000 \mathrm{~g}$ e as células ressuspendidas em $500 \mu \mathrm{l}$ de TE $(10 \mathrm{mM}$ de Tris$\mathrm{HCl}$; $\mathrm{pH}$ 8,0), centrifugadas e ressuspendidas novamente em $500 \mu \mathrm{l}$ de TE, juntamente com 0,5 g de pérolas de vidro (0,1 mm de diâmetro - Sigma) e $15 \mu \mathrm{l}$ de SDS $20 \%$. As células foram agitadas em homogeneizador de células (MineBeadbeater $^{T M}$, Biospec Products) por $30 \mathrm{~s}$ a 3500 bpm. Ao lisado celular foram adicionados $500 \mu \mathrm{l}$ de fenol, homogeneizados por inversão e centrifugado por 5 min a $14000 \mathrm{~g}$. A fase aquosa foi extraída uma vez com fenol-clorofórmio (1:1) e uma vez com clorofórmio, e o DNA precipitado com 1/10 volume de $\mathrm{NaCl} 5 \mathrm{M} \mathrm{e}$ 0,6 volume de isopropanol ( $3 \mathrm{~min}$ à temperatura ambiente). A solução foi centrifugada (10 min a $14000 \mathrm{~g}$ ), o DNA precipitado foi lavado com etanol 70\%, seco a $37^{\circ} \mathrm{C}$ e ressuspendido em $50 \mu \mathrm{l}$ de água milli-Q esterilizada. O DNA total foi analisado por eletroforese em gel de agarose $(0,8 \%$ p/v) em tampão 1x TAE (40 mM de Tris-acetato; $1 \mathrm{mM}$ de EDTA) e corado com brometo de etídio (0,5 $\mu \mathrm{g} / \mathrm{ml}$ ), segundo Sambrook et al. (1989).

\subsubsection{Amplificação e restrição do 16S rDNA (ARDRA)}

A amplificação do 16S rDNA foi realizada utilizando-se a técnica de PCR com os primers universais P027F (5'-GAGAGTTTGATCCTGGCTCAG-3') e 1378R (5'-CGGTGTGTACAAGGCCCGGGAACG-3'). As reações apresentaram um volume final de $50 \mu$ l contendo 0,5 a $10 \mathrm{ng}$ de DNA molde; 
0,2 $\mu \mathrm{M}$ de cada primer; $0,2 \mathrm{mM}$ de cada dNTPs; $3,75 \mathrm{mM}$ de $\mathrm{MgCl}_{2}$ e $0,05 \mathrm{U}$ da enzima Taq DNA polimerase (Invitrogen) em 20 mM de Tris- $\mathrm{HCl}$ pH 8,4 e 50 $\mathrm{mM} \mathrm{KCl}$. Em todas as reações foi utilizado um controle negativo sem o DNA molde.

A reação de amplificação foi realizada em termociclador (Perkin-Elmer GeneAmp $^{\circledR}$ PCR System 9700) programado para realizar uma desnaturação inicial a $94^{\circ} \mathrm{C}$ por $4 \mathrm{~min}, 25$ ciclos de desnaturação a $94^{\circ} \mathrm{C}$ por $30 \mathrm{~s}$, anelamento a $63^{\circ} \mathrm{C}$ por 1 min e extensão de primers a $72^{\circ} \mathrm{C}$ por $1 \mathrm{~min}$, seguida de extensão final a $72^{\circ} \mathrm{C}$ por $7 \mathrm{~min}$. Após a amplificação, $5 \mu \mathrm{l}$ da reação de PCR foram avaliados por eletroforese em gel de agarose $(1,2 \%$ p/v) em tampão 1x TAE e corado com brometo de etídio $(0,5 \mu \mathrm{g} / \mathrm{ml})$, para visualização de um fragmento de aproximadamente $1350 \mathrm{pb}$.

A ribotipagem do $16 \mathrm{~S}$ rDNA foi obtida pela utilização da técnica de ARDRA (Amplified Ribosomal DNA Restriciton Analysis). Para isso, $1 \mu \mathrm{g}$ do fragmento de $16 \mathrm{~S}$ rDNA amplificado foi clivado com as enzimas de restrição Mbol, Alul e Haelll, separadamente, de acordo com as recomendações do fabricante (Invitrogen). Após a digestão, toda a reação foi analisada por eletroforese em gel de agarose $(2,5 \% \mathrm{p} / \mathrm{v})$ em tampão $1 \mathrm{x}$ TAE, juntamente com o marcador de peso molecular DNA Ladder 100 pb (Invitrogen). Em seguida, o gel foi corado com brometo de etídio $(0,5 \mu \mathrm{g} / \mathrm{ml})$, observado sobre luz ultravioleta e fotodocumentado.

\subsubsection{Análise do polimorfismo gerado por marcadores de RAPD}

A variabilidade genética de bactérias endofíticas com capacidade de utilizar o glifosato como única fonte de carbono foi analisada por meio da técnica de RAPD (Random Amplified Polymorphic DNA) com os primers aleatórios: AX17 (5'-TGGGCTCTGG-3'); AX19 (5'-CCCTGTCGCA-3'); OPC02 (5'-GTGAGGCGTC-3') e OPCO8 (5'-TGGACCGGTG-3') (Operon Technologies, Alameda, CA, EUA). As reações apresentaram um volume final de $30 \mu \mathrm{l}$ 
contendo 2 a $5 \mathrm{ng}$ de DNA molde; $0,4 \mathrm{mM}$ de cada primer; $0,2 \mathrm{mM}$ de cada dNTPs; 5 mM de $\mathrm{MgCl}_{2}$ e 1,5 $\mathrm{U}$ da enzima Taq DNA polimerase (Invitrogen) em $20 \mathrm{mM}$ de Tris- $\mathrm{HCl}$ pH 8,4 e $50 \mathrm{mM} \mathrm{KCl}$. Em todas as reações foi utilizado um controle negativo sem o DNA molde.

A reação de amplificação foi realizada em termociclador (Perkin-Elmer GeneAmp ${ }^{\circledR}$ PCR System 9700) programado para realizar uma desnaturação inicial a $92^{\circ} \mathrm{C}$ por $4 \mathrm{~min}, 40$ ciclos de desnaturação a $92^{\circ} \mathrm{C}$ por $1 \mathrm{~min}$, anelamento a $37^{\circ} \mathrm{C}$ por 2 min e extensão de primers a $72^{\circ} \mathrm{C}$ por $3 \mathrm{~min}$, seguida de extensão final a $72^{\circ} \mathrm{C}$ por $3 \mathrm{~min}$. Os fragmentos amplificados foram separados por eletroforese em gel de agarose (1,4\% p/v) em tampão 1x TAE e corado com brometo de etídio $(0,5 \mu \mathrm{g} / \mathrm{ml})$, juntamente com o marcador de peso molecular DNA Ladder 50 pb (Invitrogen). Em seguida, o gel foi corado com brometo de etídio $(0,5 \mu \mathrm{g} / \mathrm{ml})$, observado sobre luz ultravioleta e fotodocumentado.

Os dados obtidos por amplificação ao acaso do DNA genômico (RAPD) foram transformados em variáveis binárias, ou seja, o número 1 significou presença de banda e o número 0 a ausência de banda. A tabela resultante foi introduzida no programa NTSYS-PC (Applied Biostatistics, Inc.), que calculou a matriz de similaridade por meio do coeficiente de Jaccard. O programa utilizou os dados da matriz de similaridade para a construção do dendrograma pelo método UPGMA (Unweighted Pair-Group Method with Arithmetical Average) de agrupamento hierárquico. $\mathrm{O}$ consenso do dendrograma foi obtido com o número de 1000 réplicas (bootstrap) pelo programa Winboot (Yap \& Nelson, 1996). O dendrograma agrupou os diferentes isolados mostrando o nível de similaridade genética entre os isolados bacterianos.

\subsubsection{Detecção do gene da nitrogenase (nifH) por meio de PCR}

A presença do gene que codifica a subunidade $\mathrm{Fe}$ da enzima nitrogenase (nifH) foi avaliada por meio da técnica de PCR com a utilização dos 
primers específicos 19F (5'-GCIWTYTAYGGIAARGGIGG-3') e 407R (5'AAICCRCCRCAIACIACRTC-3'), segundo Ueda et al. (1995). As reações de PCR foram realizadas em um volume final de $25 \mu \mathrm{l}$, contendo 0,5 a $10 \mathrm{ng}$ de DNA molde; $1 \mu \mathrm{M}$ de cada primer; 0,2 mM de cada dNTPs; 1,5 mM de $\mathrm{MgCl}_{2} \mathrm{e}$ 0,05 U da enzima Taq DNA polimerase (Invitrogen) em $20 \mathrm{mM}$ de Tris- $\mathrm{HCl} \mathrm{pH}$ 8,4 e $50 \mathrm{mM} \mathrm{KCl}$. Em todas as reações foram utilizados dois controles positivos, com o DNA molde da linhagem SR1.6/6 de Methylobacterium mesophilicum (Araújo, 2000) e da linhagem BR11281 de Gluconoacetobacter diazotrophicus (EMBRAPA/Agrobiologia), e um controle negativo sem o DNA molde.

A reação de amplificação foi realizada em termociclador (Perkin-Elmer GeneAmp ${ }^{\circledR}$ PCR System 9700) programado para realizar uma desnaturação inicial a $94^{\circ} \mathrm{C}$ por $5 \mathrm{~min}, 35$ ciclos de desnaturação a $94^{\circ} \mathrm{C}$ por $30 \mathrm{~s}$, anelamento a $59^{\circ} \mathrm{C}$ por 1 min e extensão de primers a $72^{\circ} \mathrm{C}$ por $30 \mathrm{~s}$, seguida de extensão final a $72^{\circ} \mathrm{C}$ por $7 \mathrm{~min}$. Após a amplificação, $10 \mu \mathrm{l}$ da reação de PCR foram avaliados por eletroforese em gel de agarose $(1,2 \%$ p/v) em tampão $1 \times$ TAE e corado com brometo de etídio $(0,5 \mu \mathrm{g} / \mathrm{ml})$, para visualização de um fragmento de 300 a 400 pb.

\subsubsection{Teste de sensibilidade ao herbicida glifosato}

Dois isolados endofíticos, com capacidade de crescer em meio de cultura tendo glifosato como única fonte de carbono, foram avaliados quanto à sensibilidade ao herbicida glifosato na presença de outra fonte de carbono. Os isolados HG13 (Burkholderia gladioli) e HG37 (Pseudomonas oryzihabitans) foram cultivados, a partir de colônias únicas, em $10 \mathrm{ml}$ de meio líquido DF acrescido com $20 \mathrm{mM}$ de glifosato e suplementado com as seguintes concentrações de glicose: $0 \% ; 0,01 \% ; 0,1 \%$ e $1 \%$. A avaliação do crescimento bacteriano foi realizada em triplicatas por meio de espectrofotômetro $\left(\mathrm{DO}_{600 \eta \mathrm{m}}\right.$, Spectra MaxPlus - Molecular Devices). A análise foi realizada após 0h, 24h, 
$48 \mathrm{~h}$ e $76 \mathrm{~h}$ de incubação a $28^{\circ} \mathrm{C}$ sob agitação constante (150 rpm). O controle do experimento foi feito nas mesmas condições, com exceção do acréscimo de glifosato ao meio de cultura.

\subsection{Resultados}

\subsubsection{Avaliação e identificação da comunidade bacteriana endofítica de soja associada à degradação de glifosato}

A utilização da metodologia de enriquecimento para o isolamento de bactérias endofíticas capazes de crescer em meio mineral (DF) utilizando o glifosato como única fonte de carbono foi eficaz, pois, possibilitou a observação de crescimento bacteriano com diferentes características morfológicas. Entretanto, dois morfogrupos (Figura 1) mais freqüentes foram selecionados para análises posteriores. Foram coletados 94 isolados bacterianos com capacidade de crescer em meio de cultura tendo o herbicida glifosato como única fonte de carbono.

Os dois morfogrupos de bactérias endofíticas mais freqüentes foram identificados, por análise de ácidos graxos (FAME) e BIOLOG, como pertencentes às espécies Burkholdedria gladioli e Pseudomonas oryzihabitans (Figura 1). A freqüência relativa destes dois grupos foi analisada em relação ao tratamento do solo (com ou sem aplicação de glifosato), cultivar, estádios de desenvolvimento do hospedeiro e tecidos vegetais. Foi possível observar que $B$. gladioli foi isolada apenas de plantas cultivadas em solo sem aplicação do glifosato e durante a fase V6 (vegetativa) (Figuras 2 e 3), enquanto que, $P$.

oryzihabitans foi isolada de todas as categorias de plantas, mas duas vezes mais freqüente em plantas provenientes de solo com aplicação do glifosato (Figura 2). Além disso, $P$. oryzihabitans foi isolada de plantas em fase de florescimento e maturação (R2 e R6, respectivamente), mas não em fase V6 (Figura 3). 

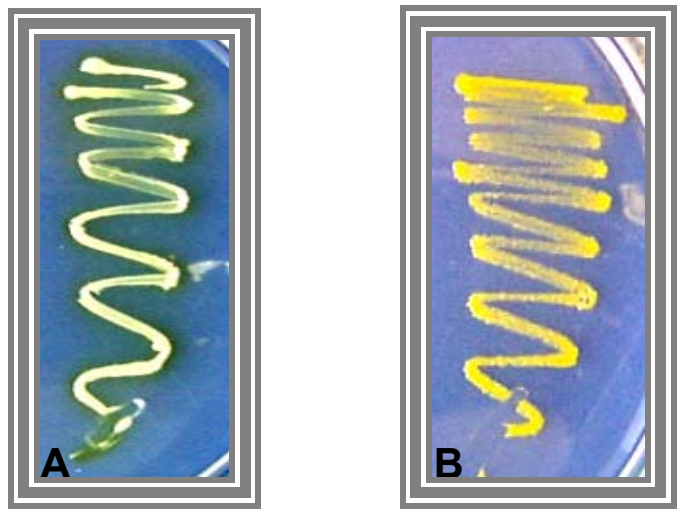

Figura 1 - Aspectos morfológicos dos dois principais grupos isolados em meio mineral DF com o herbicida glifosato como única fonte de carbono. A) B. gladioli; B) P. oryzihabitans

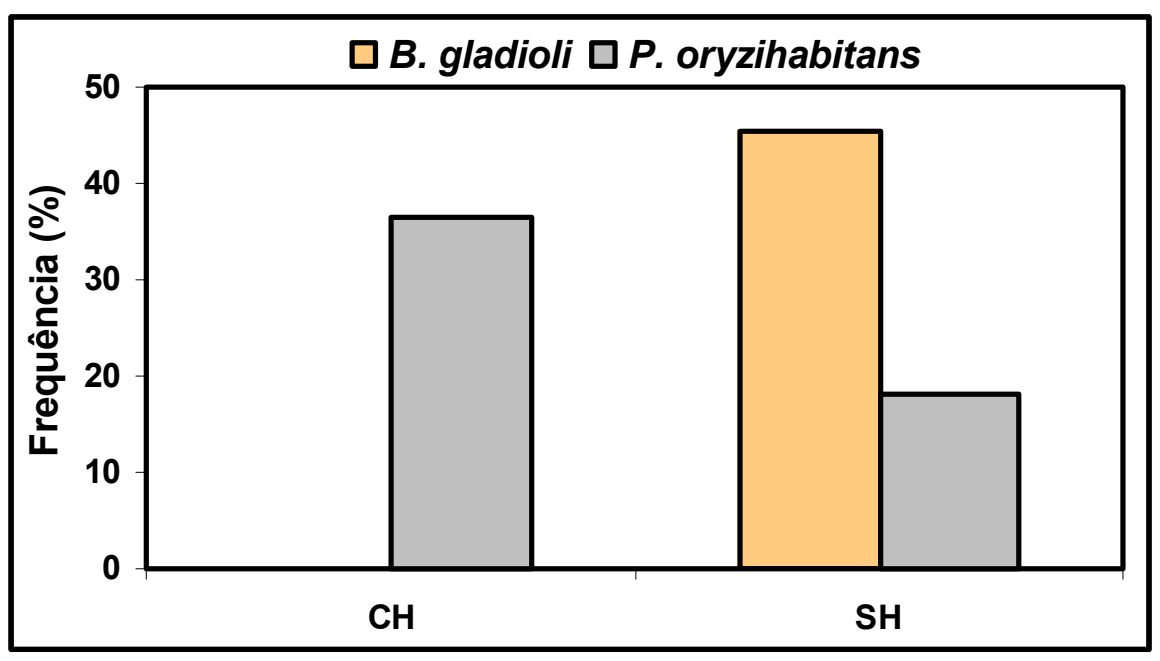

Figura 2 - Freqüência relativa de $B$. gladioli e $P$. oryzihabitans endofíticas, com capacidade de crescer em meio de cultura tendo o herbicida glifosato como única fonte de carbono, em relação ao tratamento do solo: com aplicação pré-plantio de glifosato $(\mathrm{CH})$ e sem aplicação (SH) 


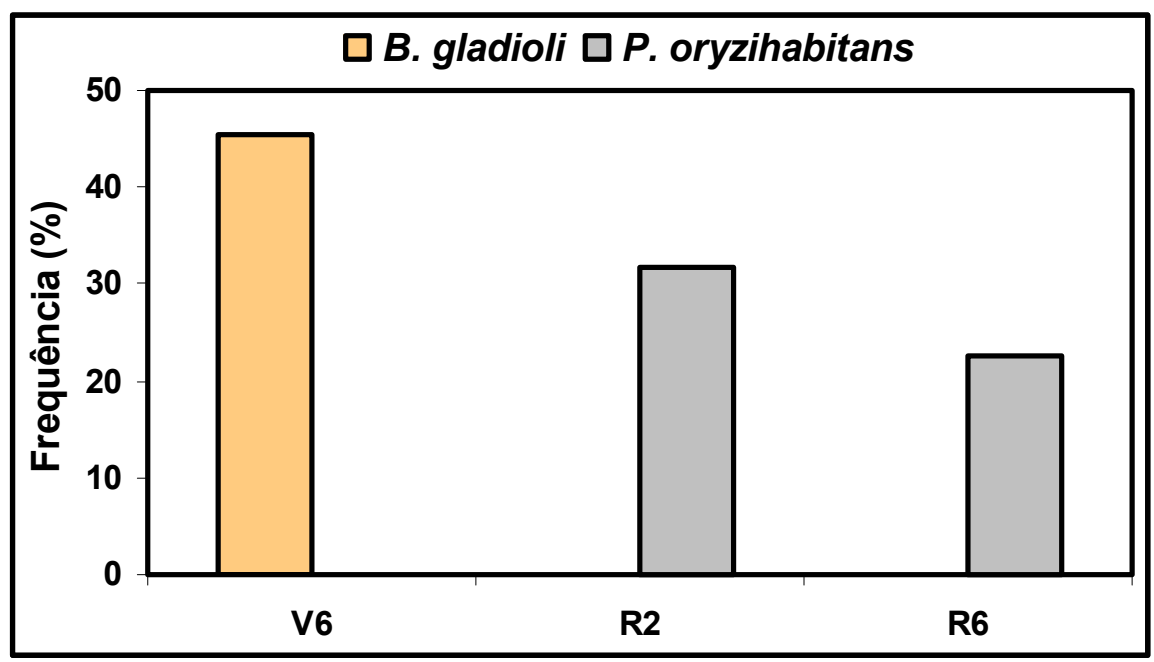

Figura 3 - Freqüência relativa de B. gladioli e $P$. oryzihabitans endofíticas, com capacidade de crescer em meio de cultura tendo o herbicida glifosato como única fonte de carbono, em relação aos estádios de desenvolvimento do hospedeiro: V6 (vegetativa); R2 (florescimento) e R6 (maturação)

Foi verificado também que $B$. gladioli apresentou maior freqüência em plantas da cultivar Foscarin (ciclo precoce), enquanto que $P$. oryzihabitans apareceu em maior freqüência em plantas da cultivar Cristalina (ciclo tardio) (Figura 4). E em relação aos tecidos vegetais, não houve especificidade dos grupos, sendo as duas espécies isoladas de todos os tecidos. Entretanto, $P$. oryzihabitans foi isolada predominantemente de folhas e $B$. gladioli apresentou maior freqüência quando isolada de caule (Figura 5). 


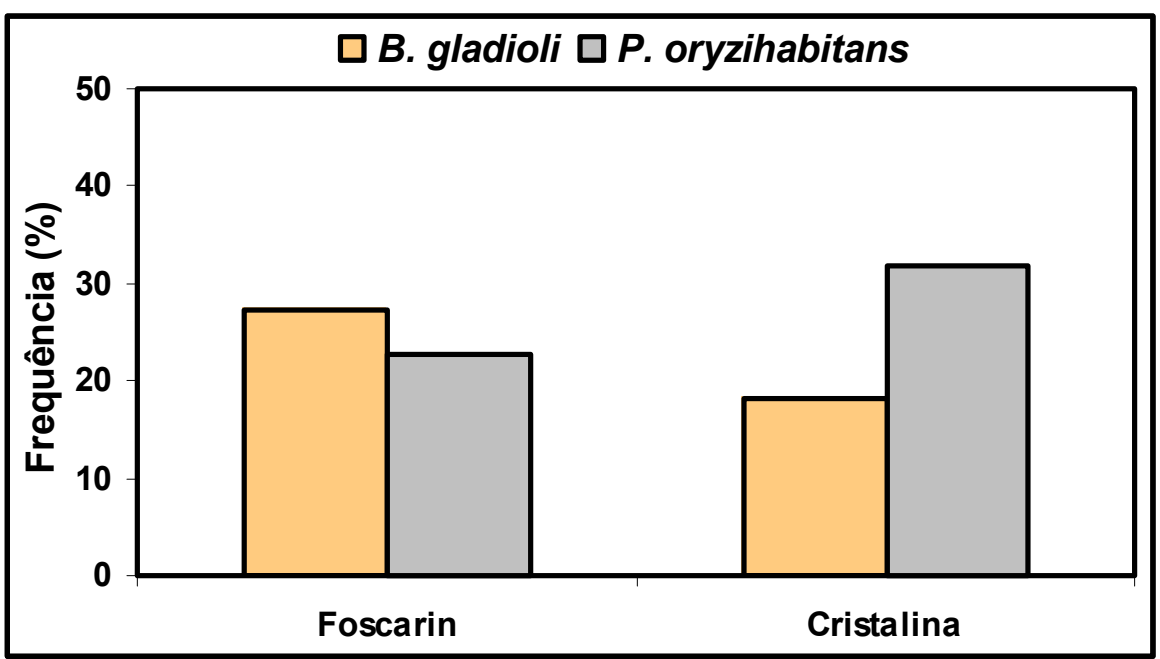

Figura 4 - Freqüência relativa de B. gladioli e $P$. oryzihabitans endofíticas, com capacidade de crescer em meio de cultura tendo o herbicida glifosato como única fonte de carbono, em relação ao genótipo do hospedeiro: cultivar Foscarin (ciclo precoce) e cultivar Cristalina (ciclo tardio)

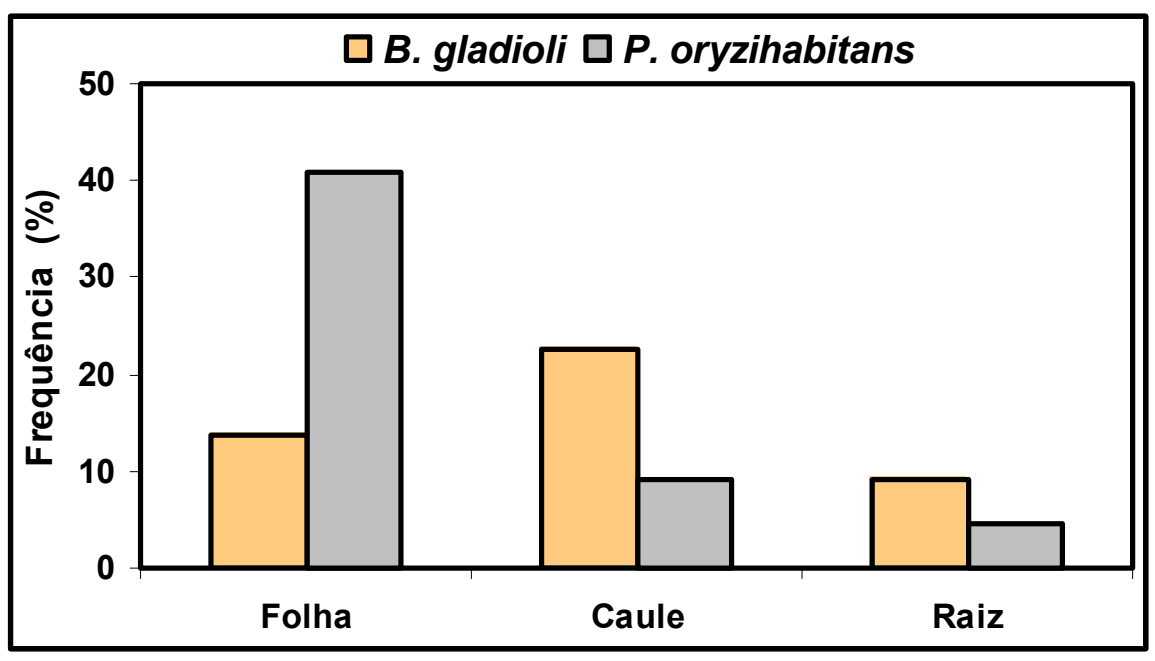

Figura 5 - Freqüência relativa de $B$. gladioli e $P$. oryzihabitans endofíticas, com capacidade de crescer em meio de cultura tendo o herbicida glifosato como única fonte de carbono, em relação aos tecidos vegetais: folha, caule e raiz 


\subsubsection{Análise da variabilidade genética e detecção do gene nifH de bactérias endofíticas de soja associadas à degradação de glifosato}

A técnica de análise de restrição do $16 \mathrm{~S}$ rDNA (ARDRA) foi utilizada para avaliar a diversidade genética entre 10 isolados (HG) endofíticos de $B$. gladioli e 12 isolados (HG) de $P$. oryzihabitans. A amplificação do 16S rDNA com primers universais para bactérias produziu uma banda única em torno de 1350 pb para todas as linhagens testadas, não mostrando polimorfismo para esta característica. Os produtos de PCR foram clivados com as enzimas de restrição Mbol, Alul e Haelll e fragmentos com tamanho entre 100 e 1000 pb foram considerados na presente análise. De acordo com o padrão de clivagem, foi possível observar 4 e 5 fragmentos por enzima de restrição, sendo detectados 2 perfis para cada enzima. A combinação dos padrões de restrição permitiu a distinção de 2 haplótipos (Tabela 1) que foram exclusivos para cada grupo bacteriano considerado. Portanto, não foi possível detectar variabilidade genética dentro de cada grupo bacteriano por análise de ARDRA.

Tabela 1. Perfil de restrição e haplótipos obtidos por ARDRA de isolados endofíticos de $B$. gladioli e $P$. oryzihabitans, com capacidade de utilizar o glifosato como única fonte de carbono

\begin{tabular}{|c|c|c|c|c|c|}
\hline \multirow{2}{*}{ Grupo } & \multirow{2}{*}{ Isolados } & \multicolumn{3}{|c|}{ Perfil de Restrição } & \multirow{2}{*}{ Haplótipo } \\
\hline & & Mbol & Alul & Haelll & \\
\hline $\begin{array}{l}\text { Burkholderia } \\
\text { gladioli }\end{array}$ & $\begin{array}{l}\text { HG9, HG10, HG11, } \\
\text { HG12, HG13, HG14, } \\
\text { HG17, HG18, HG19, HG20 }\end{array}$ & 1 & 1 & 1 & A \\
\hline $\begin{array}{c}\text { Pseudomonas } \\
\text { oryzihabitans }\end{array}$ & $\begin{array}{l}\text { HG27, HG30, HG37, HG46 } \\
\text { HG53, HG54, HG61, HG69 } \\
\text { HG71, HG74, HG85, HG94 }\end{array}$ & 2 & 2 & 2 & B \\
\hline
\end{tabular}

Tendo em vista os resultados da análise de ARDRA, a variabilidade genética dos isolados endofíticos analisados foi avaliada por marcadores 
RAPD. A análise de RAPD com 4 primers aleatórios possibilitou a observação de 50 bandas monofórficas e polimórficas nos isolados de $B$. gladioli e 56 bandas nos isolados de $P$. oryzihabitans, nas quais o tamanho variou de 250 a 1000 bp. O padrão de bandas obtido com o primer OPC02 pode ser observado na Figura 6.

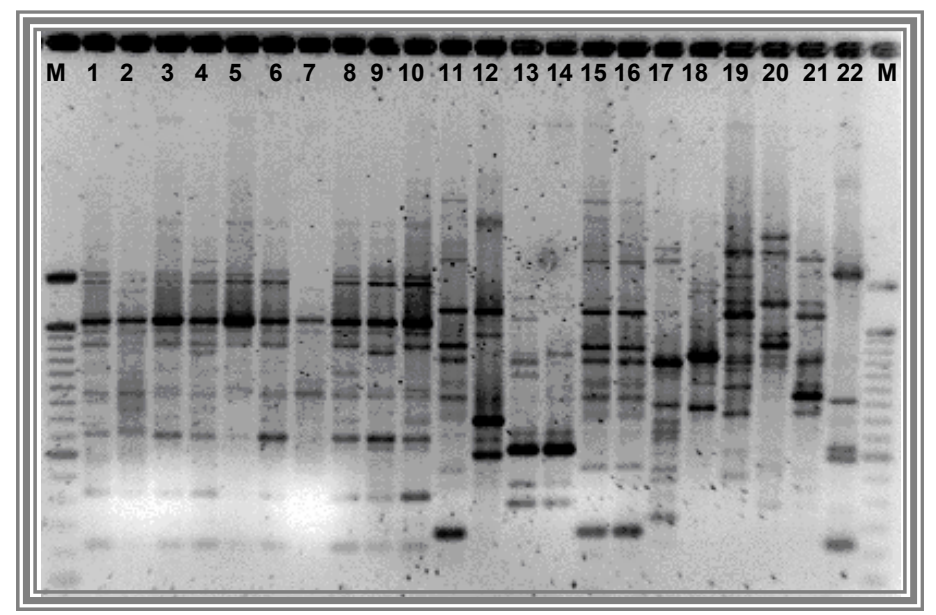

Figura 6 - Perfil eletroforético obtido com o primer OPC02 para os isolados de B. gladioli [HG9 (1); HG10 (2); HG11 (3); HG12 (4); HG13 (5); HG14 (6); HG17 (7); HG18 (8); HG19 (9); HG20 (10)] e P. oryzihabitans [HG27 (11); HG30 (12); HG37 (13); HG46 (14); HG53 (15); HG54 (16); HG61 (17); HG69 (18); HG71 (19); HG74 (20); HG85 (21); HG94 (22)], M) Marcador DNA Ladder 50 pb (Invitrogen)

De acordo com os dendrogramas obtidos, foram observados diferentes níveis de similaridade genética, mas de forma geral a variabilidade genética observada foi alta dentro de cada grupo, visto que a similaridade genética mínima de B. gladioli e $P$. oryzihabitans foi cerca de $54 \%$ e $66 \%$ (Figuras 7 e 8), respectivamente. Além disso, não foi possível correlacionar os agrupamentos formados por RAPD com o tratamento do solo, cultivar ou tecido da planta.

A potencial habilidade de fixar nitrogênio atmosférico em bactérias endofíticas, com capacidade de utilizar o herbicida glifosato como única fonte de carbono, foi avaliada por meio da detecção do gene que codifica a 
subunidade Fe da enzima nitrogenase (nifH). O PCR específico para o gene nifH foi realizado nos mesmos isolados avaliados quanto à variabilidade genética, ou seja, 10 isolados $B$. gladioli e 12 isolados de $P$. oryzihabitans. Foi observado que nenhum dos isolados pertencentes ao grupo de $B$. gladioli apresentaram reação de PCR positiva para este gene. Entretanto, o gene nifH foi detectado em $33,3 \%$ dos isolados de $P$. oryzihabitans.

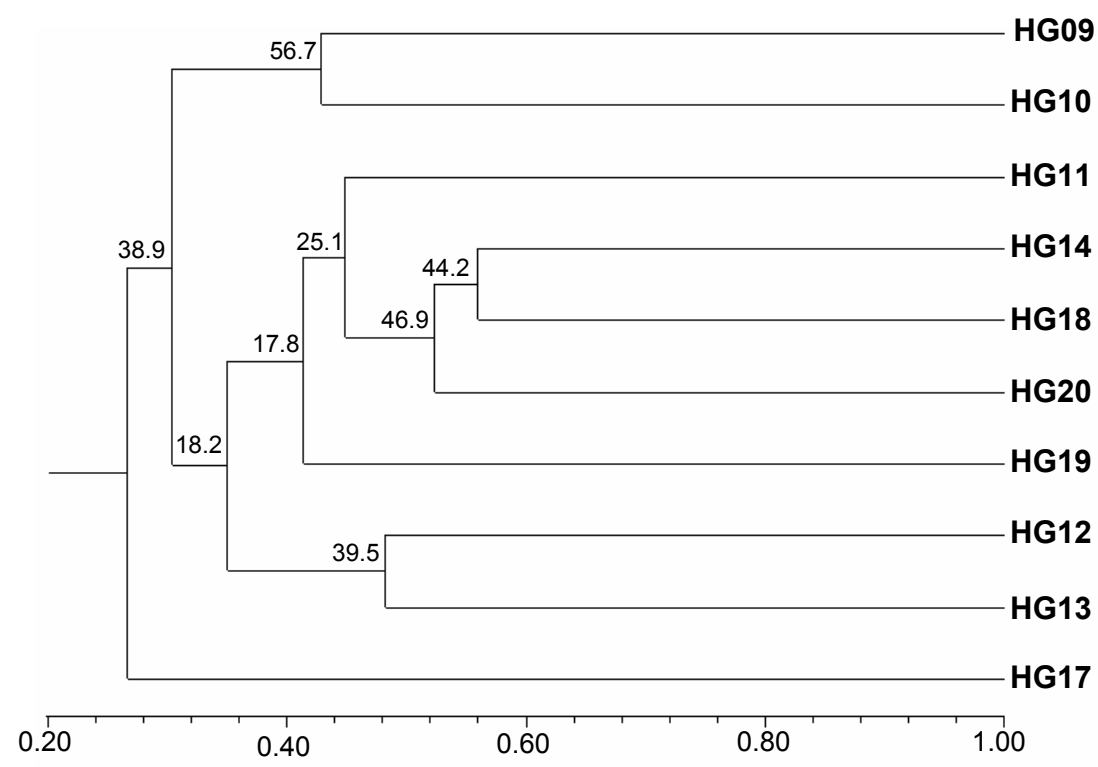

Figura 7 - Dendrograma obtido pelo método de UPGMA a partir da matriz de similaridade genética entre os isolados endofíticos de $B$. gladioli, obtidos de folha, caule e raiz das cultivares Foscarin e Cristalina, crescidas em solo sem aplicação do herbicida glifosato, durante o estádio de desenvolvimento V6 da soja. O coeficiente de Jaccard foi utilizado para a construção da matriz de similaridade. Os números no dendrograma indicam a porcentagem de vezes que o grupo da direita ocorreu no mesmo nó durante a avaliação do consenso (bootstrap) 


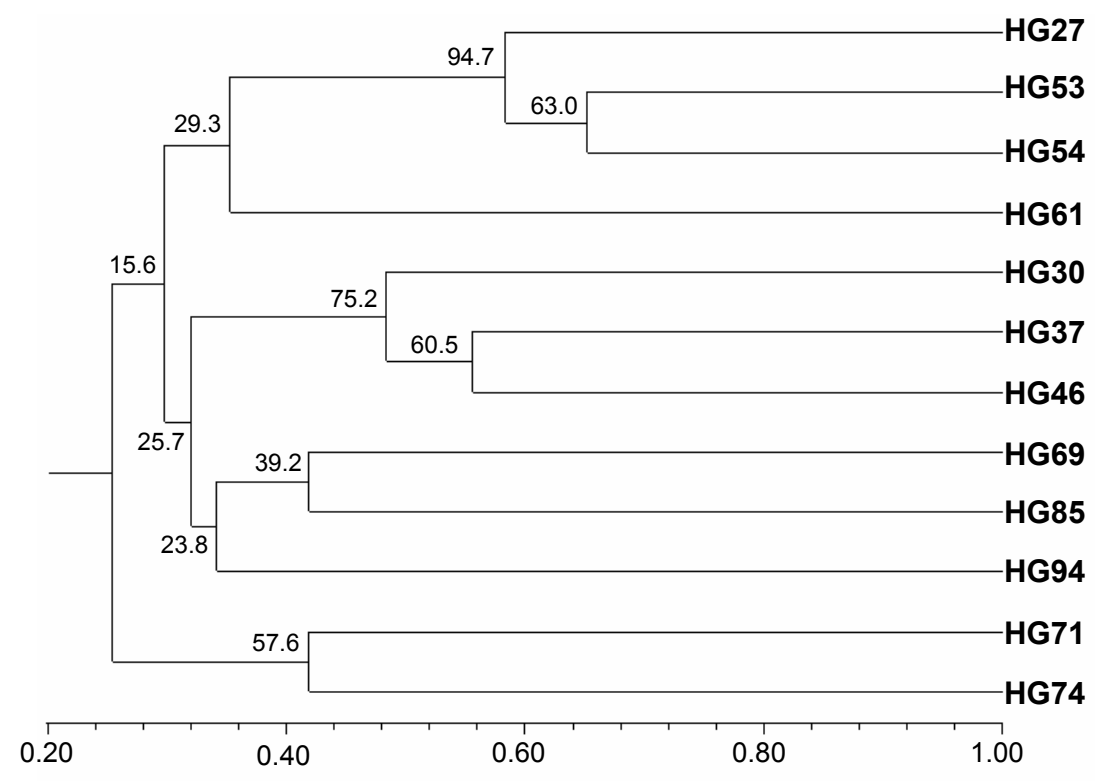

Figura 8 - Dendrograma obtido pelo método de UPGMA a partir da matriz de similaridade genética entre os isolados endofíticos de $P$. oryzihabitas, obtidos de folha, caule e raiz das cultivares Foscarin e Cristalina, crescidas em solo com e sem aplicação pré-plantio do herbicida glifosato, durante os estádios de desenvolvimento R2 e R6 da soja. O coeficiente de Jaccard foi utilizado para a construção da matriz de similaridade. Os números no dendrograma indicam a porcentagem de vezes que o grupo da direita ocorreu no mesmo nó durante a avaliação do consenso (bootstrap)

\subsubsection{Sensibilidade ao herbicida glifosato por Burkholderia gladioli e Pseudomonas oryzihabitans}

Os isolados HG13 (B. gladioli) e HG37 ( $P$. oryzihabitans) foram avaliados quanto à sensibilidade ao herbicida glifosato, tendo uma fonte de carbono alternativa (glicose). Nas condições utilizadas durante os experimentos, os dois isolados apresentaram taxa de crescimento diferentes, sendo observado que o isolado de $B$. gladioli (HG13) obteve a média máxima 
de densidade ótica $(600 \eta \mathrm{m})$ igual a 0,30 e o isolado de $P$. oryzihabitans obteve 0,09 . Além disso, foi possível observar que as duas espécies bacterianas responderam de forma diferente à presença do glifosato. $\mathrm{O}$ isolado HG13 mostrou maior tolerância ao glifosato, apresentado taxa de crescimento semelhante nas condições avaliadas (Figura 9). Entretanto, o isolado HG37 apresentou sensibilidade ao glifosato, pois, apresentou taxa de crescimento significativamente maior em meio de cultura sem o acréscimo de glifosato (Figura 10A). 

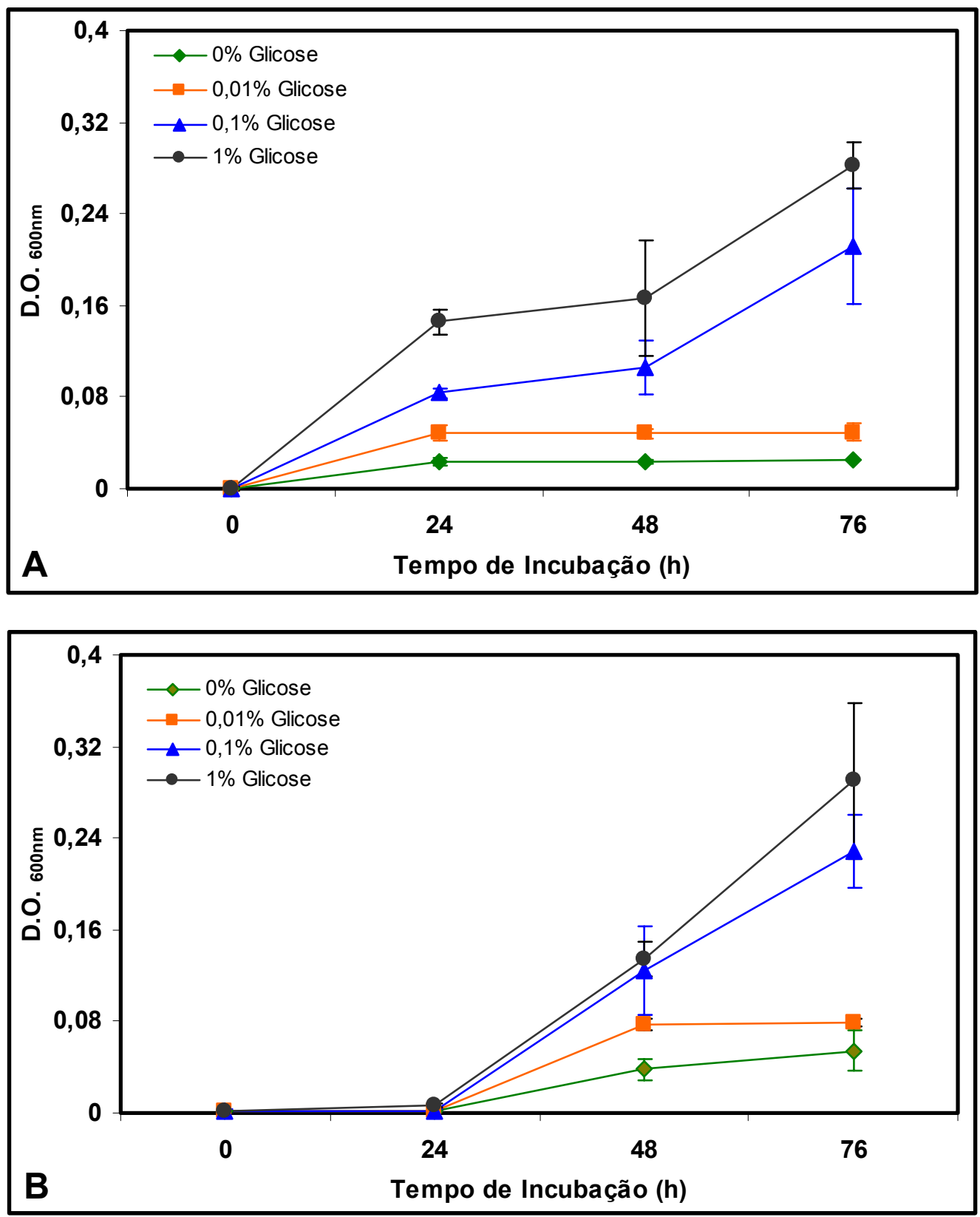

Figura 9 - Curvas de crescimento do isolado HG13 (B. gladioli) em meio mineral DF sem (A) e com (B) o acréscimo de $20 \mathrm{mM}$ do herbicida glifosato em diferentes concentrações de glicose: 0\%; 0,01\%; 0,1\% e 1\% 

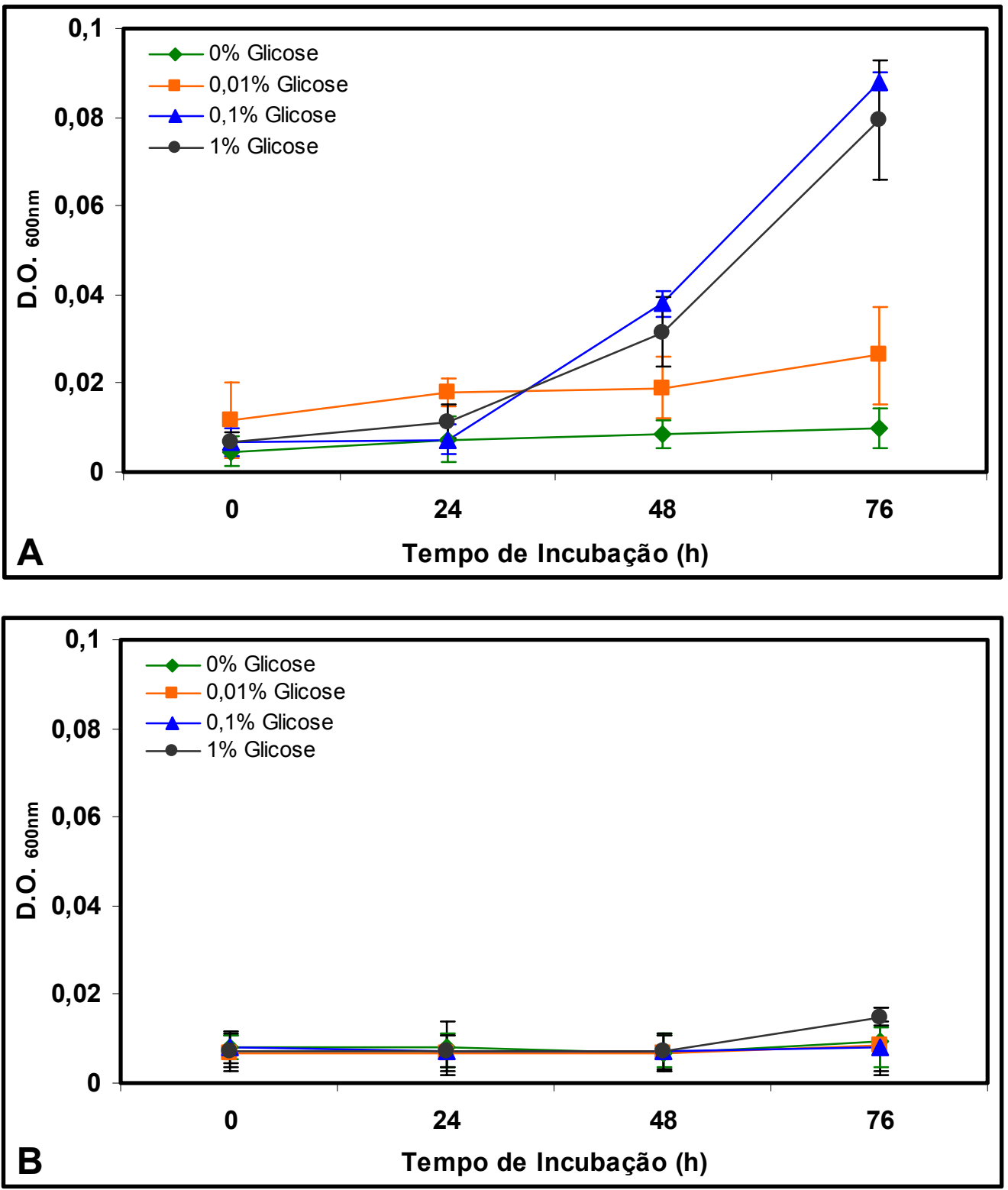

Figura 10 - Curvas de crescimento do isolado HG37 ( $P$. oryzihabitans) em meio mineral DF sem (A) e com (B) o acréscimo de $20 \mathrm{mM}$ do herbicida glifosato em diferentes concentrações de glicose: $0 \% ; 0,01 \% ; 0,1 \%$ e $1 \%$ 


\subsection{Discussão}

A necessidade do aumento da produção de alimentos gerou a busca por novas estratégias e tecnologias na produção vegetal, entre elas, o desenvolvimento de plantas transgênicas. Apesar do grande número de plantas geneticamente modificadas liberadas para testes em campo e, algumas já comercializadas no mundo, pouco é conhecido a respeito do impacto destas plantas e dos processos associados às plantas sobre os microrganismos que interagem com os vegetais (Azevedo \& Araújo, 2003). O desenvolvimento da soja transgênica resistente ao herbicida glifosato, sugere que a utilização em campo deste herbicida poderá aumentar com a liberação deste transgênico. Além do pouco conhecimento a respeito da interação microrganismos-plantas transgênicas, deve-se considerar as possíveis conseqüências que este produto resultará. Neste contexto, podemos sugerir que o aumento da aplicação de glifosato poderia favorecer a seleção de microrganismos capazes de degradar este composto, em detrimento a espécies sensíveis a este herbicida.

O glifosato [( $\mathrm{N}$-fosfonometil) glicina] é um herbicida não seletivo que atua inibindo a enzima 5-enolpiruvilshiquimato-3-fosfato sintetase (EPSPS) da via metabólica do ácido shiquímico, que está envolvido na síntese de aminoácidos aromáticos essenciais (Penazola-Vazquez et al., 1995). Apesar dos microrganismos possuírem a via do ácido shiquímico, há grupos microbianos que são capazes de utilizar o glifosato como fonte de energia e nutrientes, como espécies dos gêneros Pseudomonas e Penicillium, enquanto que em outros grupos microbianos este herbicida apresenta ação tóxica, como para Fusarium oxysporum e Rhizoctonia cerealis (Levesque \& Rahe, 1993; Santos \& Flores, 1995; Dick \& Quinn, 1995; Busse et a., 2001). Além disto, este herbicida é um organofosfonato caracterizado pela presença de uma ligação covalente estável carbono-fósforo (C-P) que pode ser quebrada por microrganismos e ser utilizada como fonte de fósforo (Penazola-Vazquez et al., 1995; Obojska et al., 1999). Porém, McGrath et al. (1998) e Ternan et al. (1998) 
mostram a utilização de diferentes compostos fosfonatos como fonte de carbono por Rhizobium huakuii e Burkholderia cepacia, sugerindo que compostos como o glifosato também possam ser utilizados como fonte de carbono.

No presente trabalho, bactérias endofíticas com capacidade de crescer em meio de cultura tendo o glifosato como única fonte de carbono foram isoladas e, dois morfogrupos mais freqüentes identificados como $B$. gladioli e $P$. oryzihabitans, foram estudados. Diversos trabalhos têm explorado a capacidade de espécies do gênero Burkholderia apresentarem diferentes características de interesse biotecnológico, tais como, controle biológico de fitopatógenos (Pan et al., 1997), promoção de crescimento vegetal (Bevivino et al., 1998), degradação de compostos xenobióticos como organofosfonato e tricloroetano (Dotson et al., 1996; Barth et al., 2002), entre outros. A espécie B. gladioli possui três patovars, sendo patogênicas para cebola e alguns cogumelos (Richardson et al., 2002), entretanto, Shimosaka et al. (2000) relatam a produção de quitinases e quitosanases por esta espécie, que são enzimas de interesse para o controle biológico de fitopatógenos. Contudo, em leguminosas, especialmente soja, não há relatos desta espécie causando danos ao vegetal. A espécie $P$. oryzihabitans tem sido isolada de diferentes ambientes, como solo, água, zonas de cultivo de arroz (Dussart et al., 2003) e, inclusive, de sementes de soja (Oehrle et al., 2000). Belimov et al. (2001) relatam que $P$. oryzihabitans isolada do rizoplano de Pisum sativum apresentou a capacidade de produzir a enzima ACC (aminociclopropano-1-carboxilato) deaminase, que hidrolisa o precursor (ACC) imediato do fitohormônio etileno, sendo, portanto, potencial para promoção de crescimento vegetal.

Bactérias endofíticas têm sido isoladas de raiz, nódulos, caule, folhas e frutos em uma extensa variedade de plantas, incluindo muitas de interesse agrícola (Stolzfus et al., 1997; Araújo et al., 2001; Reiter $t$ al., 2002; Zinniel et al., 2002). Estes endófitos podem influenciar o desenvolvimento da planta 
hospedeira por meio da supressão de doenças, degradação de contaminantes e promoção de crescimento vegetal (Sturz et al., 2000; Siciliano et al., 2001; Lodewyckx et al., 2002). Portanto, o estudo de bactérias endofíticas é importante não apenas para entender o seu papel ecológico na interação com plantas, mas também para aplicações biotecnológicas. Contudo, há poucos trabalhos a respeito da interação do herbicida glifosato com a comunidade microbiana endofítica. Prestidge \& Sprosen (1995) avaliaram a aplicação do glifosato em Lolium perenne colonizado pelo fungo endofítico Acremonium Iolii, mas observaram que este herbicida não alterou a concentração do alcalóide lolitrem B, produzido pelo endófito na planta hospedeira.

Muitos trabalhos têm relatado a influência de diferentes fatores sobre a comunidade microbiana associada às plantas, como mudanças sazonais (Mocali et al., 2003), cultivares e espécies de plantas, tipos de solo (Dalmastri et al., 1999; Fromin et al., 2001) e interação com outros microrganismos (Araújo et al., 2001; Araújo et al., 2002). No presente trabalho foi observado que o solo com e sem aplicação em pré-plantio do herbicida glifosato e o estádio de desenvolvimento do hospedeiro podem influenciar estas bactérias, pois $B$. gladioli foi isolada apenas de plantas cultivadas em solo sem aplicação do glifosato e durante a fase V6 da soja (vegetativa). Estes resultados sugerem que esta espécie poderia ter um papel no estabelecimento inicial da interação bactéria-planta em solo específico. Além disso, $P$. oryzihabitans foi isolada de plantas em fase de florescimento e amadurecimento (R2 e R6, respectivamente), indicando que esta espécie poderia ser importante durante estas fases de desenvolvimento da soja.

A análise de marcadores RAPD não apresentou correlação dos agrupamentos formados com a origem dos isolados, podendo-se inferir que populações bacterianas endofíticas da espécie B. gladioli apresentam a capacidade de colonizar diferentes tecidos vegetais e diferentes cultivares de soja, enquanto que populações de $P$. oryzihabitans, além destas características, possam se manter no hospedeiro durante diferentes fases do desenvolvimento 
vegetal. A variabilidade genética de $B$. gladioli e $P$. oryzihabitans é alta, mostrando que mais de um genótipo possui a capacidade de utilizar o glifosato como fonte de carbono. Além disso, esta variabilidade genética permite que mudanças no ambiente mantenha este grupo, visto que diferentes genótipos poderiam ser selecionados.

Embora os isolados avaliados tenham sido obtidos em meio de cultura tendo glifosato com única fonte de carbono, foi observado que $P$. oryzihabitans apresenta pouca tolerância a este herbicida, sugerindo que o seu crescimento durante a técnica de enriquecimento esteja relacionada ao seu cocultivo com $B$. gladioli, que poderia quebrar a molécula e ser, então, utilizada por $P$. oryzihabitans. Portanto, um aumento na utilização deste herbicida poderia alterar populações endofíticas com potencial para biodegradação de compostos xenobióticos e promoção de crescimento vegetal, visto que $P$. oryzihabitans apresentou $30 \%$ dos isolados com reação de PCR positiva para o gene nifH.

\subsection{Conclusões}

Os resultados apresentados permitem concluir que:

a) isolados endofíticos de Burkholderia gladioli e Pseudomonas oryzihabitans são capazes de utilizar o glifosato como única fonte de carbono;

b) a variabilidade genética em isolados endofíticos de $B$. gladioli e $P$. oryzihabitans capazes de utilizar o glifosato como única fonte de carbono é alta;

c) B. gladioli é mais tolerante ao glifosato que $P$. oryzihabitans;

d) diferentes fatores (aplicação de glifosato, genótipo do hospedeiro, estádio de desenvolvimento da planta, tecido vegetal) podem influenciar a interação entre bactérias endofíticas associadas à degradação do glifosato e a planta hospedeira. 


\section{ESTUDO DA INTERAÇÃO Methylobacterium spp. ENDOFÍTICAS E SOJA}

\section{Resumo}

Estudos recentes têm mostrado que o gênero Methylobacterium pode estar envolvido na formação de nódulos e fixação de nitrogênio em leguminosas, sugerindo que este grupo poderia ter importante envolvimento na interação bactérias-leguminosas. Entretanto, poucos trabalhos foram realizados com o objetivo de avaliar a interação entre Methylobacterium spp. endofíticas e soja. Desta forma, o objetivo do presente estudo foi isolar Methylobacterium spp. endofíticas de caules e raízes de soja e estudar mecanismos de interação endófito-hospedeiro. Bactérias endofíticas, em especial as pertencentes ao grupo Methylobacterium, foram isoladas de caules e raízes de plantas cultivadas em solo com e sem aplicação em pré-plantio do herbicida glifosato, durante dois anos. Foi observado que a densidade populacional de Methylobacterium em raiz sofreu influência da aplicação de glifosato aplicado em pré-plantio, pois, estes endófitos foram isolados apenas de plantas cultivadas em solo com aplicação de glifosato. Além disso, esta população também foi influenciada pela variação sazonal, apresentando significante diferença entre as densidades populacionais das duas safras. Entretanto, a população endofítica de Methylobacterium de caule foi estável e não apresentou alterações em relação aos fatores analisados. Outro aspecto avaliado foi a capacidade de colonização em plântulas pelas linhagens SR1.6/6 de M. mesophilicum (endofítica de citros) e EN29C de Methylobacterium sp. (endofítica de soja). Esta avaliação foi realizada por meio de microscopia 
eletrônica de varredura possibilitando o estudo do processo de colonização em folhas, caules e raízes por Methylobacterium. Observou-se que as linhagens endofíticas de Methylobacterium foram capazes de colonizar todos os tecidos avaliados, inclusive apresentando aglomerados celulares em prováveis regiões de entrada para os tecidos internos do hospedeiro. Os resultados sugerem que o grupo Methylobacterium poderia apresentar significante interação com plantas de soja, uma vez que sua densidade e colonização foram representativas nas condições observadas.

\section{Summary}

Recent studies have shown that the Methylobacterium genus may be involved in the nodules formation and nitrogen fixation in leguminous, suggesting that this group could have important involvement in the interaction bacteria-leguminous. However, few researches has been carried out about endophytic Methylobacterium spp. and soybean interaction. Therefore, the aim of this study was to isolate endophytic Methylobacterium from stems and roots of soybean plants and study the settling on this bacterium inside the host plant. Endophytic bacteria, especially belonging to Methylobacterium genus, were isolated from stems and roots of soybean plants cultivated in soil with and without glyphosate application in pre-planting, during two years. It was observed that the population density of Methylobacterium in roots suffered influence of the glyphosate application in pre-planting, because these endophytes were isolated only from plants cultivated in soil with glyphosate application. Besides, this population was also influenced by the seasonal variation, presenting significant difference among the population densities of the two crops. However, the Methylobacterium endophytic population of stem was stable and it did not present alterations in relation to the analyzed factors. Another appraised aspect was the colonization capacity in soybean seedlings by the $M$. mesophilicum strains SR1.6/6 (isolated from citrus) and Methylobacterium sp. isolate EN29C 
(from soybean). This evaluation was accomplished through scanning electron microscopy that allowed the study of the colonization process in leaves, stems and roots by Methylobacterium. It was observed that the Methylobacterium endophytic strains were capable to colonize all the evaluated tissues, include presenting cellular agglomerates in probable entry for into plant tissues. The results suggest that the group Methylobacterium could present significant interaction with soybean plants, once your density and colonization were representative in the observed conditions.

\subsection{Introdução}

A interação microrganismos-planta é muito dinâmica e complexa, sendo difícil uma distinção entre microrganismos endofíticos, epifíticos e fitopatogênicos, ocorrendo em muitos casos sobreposição destes grupos de microrganismos. São denominados de endófitos aqueles microrganismos que habitam o interior dos tecidos vegetais, em parte ou durante todo o seu ciclo de vida, sem causar danos aparentes ao seu hospedeiro, enquanto que os microrganismos epifíticos são aqueles que habitam a superfície do vegetal (Hallmann et al., 1997b; Chanway, 1998; Azevedo et al., 2000b; Lodewyckx et al., 2002).

Os mecanismos envolvidos na interação bactérias-planta podem envolver diversos fatores bióticos e abióticos, os quais influenciam os diferentes níveis de interação, necessitando de estudos para uma correta utilização de suas propriedades. Alguns estudos têm mostrado que bactérias endofíticas podem conferir ao seu hospedeiro maior resistência a condições de estresse, alterações nas condições fisiológicas, proteção contra organismos patogênicos (indução de resistência sistêmica e antibiose) e herbívoros, produção de reguladores de crescimento vegetal (fitohormônios), bem como, produção de componentes de interesse biotecnológico. Estas bactérias também podem ser modificadas geneticamente e introduzidas na planta hospedeira conferindo 
características desejáveis à mesma (Quadt-Hallmann et al, 1997b; Azevedo, 1998a; Shishido et al., 1999; Azevedo et al., 2000a,b; Sturz et al., 2000; Lodewyckx et al., 2002).

A origem, forma de penetração, colonização e transmissão de bactérias endofíticas ainda são muito discutidas, mas acredita-se que podem estar presentes nas sementes, rizosfera, filoplano e em material propagado vegetativamente (Di Fiore \& Del Gallo, 1995; Quadt-Hallmann et al., 1997a; Hallmann et al., 1997b; Reinhold-Hurek \& Hurek, 1998; McCully, 2001). Bactérias endofíticas têm sido isoladas de raiz, nódulos, caule, folhas e frutos numa extensa variedade de plantas, incluindo muitas de interesse agrícola como cana-de-açúcar (Cavalcante \& Dobereiner, 1988), milho (Mclnroy \& Kloepper, 1995b; Araújo et al., 2000), algodão (Quadt-Hallmann et al, 1997a), arroz (Stolzfus et al, 1997), citros (Araújo et al., 2001, Araújo et al. 2002), batata (Reiter et al., 2002), trigo e sorgo (Zinniel et al., 2002), entre outras. Mostrando, portanto, a importância do amplo conhecimento sobre os mecanismos de estabelecimento e interação endófitos-planta, que poderá permitir a utilização destes microrganismos na agricultura, indústria e biotecnologia.

Diante do exposto, o presente trabalho teve como objetivos: (i) isolar e identificar bactérias endofíticas, com ênfase ao grupo Methylobacterium, de caules e raízes de soja; (ii) avaliar a possível influência de dois fatores ambientais (variação sazonal e solo com e sem aplicação do herbicida glifosato) sobre populações endofíticas de Methylobacterium spp.; (iii) reinocular duas linhagens de Methylobacterium em sementes de soja e, avaliar, por meio de microscopia eletrônica de varredura, a colonização destas bactérias em plântulas. 


\subsection{Material e Métodos}

\subsubsection{Material vegetal}

Bactérias endofíticas foram isoladas de caules e raízes de soja [Glycine $\max$ (L.) Merrill] da cultivar Cristalina (ciclo tardio) no estádio fenológico R6 (maturação), segundo Neumaier et al. (2000). As plantas foram cultivadas na área experimental do Campus da Escola Superior de Agricultura "Luiz de Queiroz" - USP, Piracicaba/SP ( $22^{\circ} 42^{\prime}$ S e $47^{\circ} 38^{\prime} \mathrm{W}$ ), durante o período das safras de 2000/01 e 2001/02. Foram utilizados dois lotes, um com aplicação pré-plantio do herbicida glifosato (1,44 Kg/ha Agrisato $480 \mathrm{CS}$ - Alkagro) e outro sem aplicação e histórico do herbicida citado. Cada lote $(2 \times 6 \mathrm{~m})$ apresentou 10 linhas e 15 plantas por linha.

A linhagem SR1.6/6 de M. mesophilicum foi previamente isolada de ramo de laranja doce (Citrus sinensis) (Araújo, 2000) e, gentilmente, cedida pelo Dr. Welington L. Araújo.

\subsubsection{Isolamento de bactérias endofíticas de soja}

Bactérias endofíticas foram isoladas após a desinfecção superficial dos tecidos, que foi realizada pelas seguintes etapas: lavagem por $1 \mathrm{~min}$ em etanol 70\%; 3 min em hipoclorito de sódio ( $\mathrm{NaOCl}$ ) a $2 \%$ de cloro ativo (v/v) acrescido de Tween $20(1 \mathrm{ml} / \mathrm{l})$ e $30 \mathrm{~s}$ em etanol $70 \%$, seguido de duas lavagens em água destilada esterilizada. Os tecidos foram cortados, assepticamente, em pequenos fragmentos e triturados em $10 \mathrm{ml}$ de tampão PBS $(1,44 \mathrm{~g} / \mathrm{l}$ de $\mathrm{Na}_{2} \mathrm{HPO}_{4} ; 0,24 \mathrm{~g} / \mathrm{l}$ de $\mathrm{KH}_{2} \mathrm{PO}_{4} ; 0,20 \mathrm{~g} / \mathrm{l}$ de $\mathrm{KCl} ; 8,00 \mathrm{~g} / \mathrm{l}$ de $\left.\mathrm{NaCl} ; \mathrm{pH} 7,4\right)$. Em seguida, todo o material foi transferido para tubos de $15 \mathrm{ml}$ e incubados sob agitação $(150 \mathrm{rpm})$ a $28^{\circ} \mathrm{C}$ por $1 \mathrm{~h}$. Diluições apropriadas em tampão PBS foram semeadas em TSA 10\% suplementado com o fungicida Benomyl (50 $\mu \mathrm{g} / \mathrm{ml}$ ). As placas foram incubadas a $28^{\circ} \mathrm{C}$ e avaliadas com 2 , 8 e 15 dias de 
crescimento. A confirmação da eficiência da desinfecção superficial dos tecidos foi avaliada, por meio da semeadura de alíquotas da água destilada utilizada na última lavagem sobre meio TSA $10 \%$ suplementado com o fungicida Benomyl $(50 \mu \mathrm{g} / \mathrm{ml}) \mathrm{e}$, incubadas a $28^{\circ} \mathrm{C}$ por $4-15$ dias.

A população bacteriana por grama de tecido vegetal fresco (UFC/g TVF) foi estimada pela contagem de colônias cultivadas em meio TSA $10 \%$. Colônias bacterianas foram repicadas das placas de isolamento, purificadas e mantidas em TSA $10 \%$ suplementado com $20 \%$ de glicerol a $-70^{\circ} \mathrm{C}$. Colônias típicas de todos os tipos morfológicos foram repicadas e selecionadas para estocagem.

\subsubsection{Reinoculação de bactérias endofíticas em sementes de soja}

Sementes da cultivar Foscarin foram lavadas em álcool (70\%) por 1 min, desinfectadas em solução de hipoclorito de sódio ( $2 \%$ de $\mathrm{Cl}^{-}$disponível) suplementado com Tween 20 (1 ml/l) por $10 \mathrm{~min}$, enxaguadas novamente em álcool $(70 \%)$ e, posteriormente, lavadas três vezes em água destilada e esterilizada. A água da última lavagem foi semeada em meio TSA $10 \%$ suplementado com o fungicida Benomyl $(50 \mu \mathrm{g} / \mathrm{ml})$ e incubada a $28^{\circ} \mathrm{C}$ por $4-15$ dias para controle do processo de desinfecção.

Após a desinfecção superficial, as sementes foram incubadas em câmara úmida por $24 \mathrm{~h}$, sendo, posteriormente, colocadas na suspensão bacteriana $\left(10^{6}-10^{7} \mathrm{UFC} / \mathrm{ml}\right.$ de PBS) e mantidas sob agitação (150 rpm) por 18 horas. Após a inoculação, as sementes foram lavadas com tampão PBS e recolocadas em câmara úmida por $24 \mathrm{~h}$ a 48 h ou até germinarem. Após este período, as sementes foram transferidas para tubos contendo meio MS (Murashigue \& Skoog, 1962) e incubadas a $28^{\circ} \mathrm{C}$ com fotoperíodo de $18 \mathrm{~h}$ por 6 h (claro-escuro). Após 15 dias de incubação, as amostras foram submetidas ao preparo para visualização sob microscopia eletrônica de varredura. No controle as sementes foram tratadas com PBS. 


\subsubsection{Preparo das amostras vegetais para MEV (Microscopia Eletrônica de Varredura)}

\subsubsection{Técnica padrão}

Pequenos fragmentos $(\cong 2 \times 2 \mathrm{~cm})$ de folha, caule e raiz de cada amostra foram seccionados, com o auxílio de estilete estéril. Este material foi submetido à técnica padrão, segundo Kitajima \& Leite (1999). Os fragmentos foram fixados em solução de Karnovksy modificado (glutaraldeído 2,5\%; formaldeído 2,5\% em tampão cacodilato de sódio $0,05 \mathrm{M} ; \mathrm{pH}$ 7,2; $\mathrm{CaCl}_{2}$ 0,001 $\mathrm{M})$ por $1 \mathrm{~h}$ à temperatura ambiente. Em seguida, foram realizadas 3 lavagens em tampão cacodilato $(0,05 \mathrm{M})$ por $10 \mathrm{~min}$. As amostras foram seccionadas para a exposição do interior dos tecidos e a pós-fixação em $\mathrm{OsO}_{4} 1 \%$ (em tampão cacodilato $0,05 \mathrm{M}$; pH 7,2) por $1 \mathrm{~h}$, as amostras foram lavadas (5X) em água destilada e desidratadas em série crescente de acetona $(30 \%, 50 \%, 70 \%$, $90 \%$ e 100\%), 10 min em cada etapa, sendo que a última etapa foi repetida três vezes. Por fim, as amostras foram secas ao ponto crítico (CPD 050, Balzers) e metalizadas com ouro (MED 010, Balzers). Depois de metalizadas, as amostras foram montadas em suportes especiais (stubs) e observadas em Microscópio Eletrônico de Varredura (DSM 900, Zeiss).

\subsubsection{Protocolo para fraturar tecidos congelados em nitrogênio líquido}

Pequenos fragmentos $(\cong 2 \times 2 \mathrm{~cm})$ de folha, caule e raiz de cada amostra foram seccionados, com o auxílio de estilete estéril. Este material foi submetido à técnica padrão, segundo Kitajima \& Leite (1999). Os fragmentos foram fixados em solução de Karnovksy modificado (glutaraldeído 2,5\%; formaldeído 2,5\% em tampão cacodilato de sódio 0,05 M; pH 7,2; $\mathrm{CaCl}_{2}$ 0,001 $\mathrm{M})$ por $1 \mathrm{~h}$ à temperatura ambiente. Em seguida, foram realizadas 3 lavagens em tampão cacodilato $(0,05 \mathrm{M})$ por $10 \mathrm{~min}$. As amostras foram seccionadas 
para a exposição do interior dos tecidos e a pós-fixação em $\mathrm{OsO}_{4} 1 \%$ (em tampão cacodilato $0,05 \mathrm{M}$; pH 7,2) por $1 \mathrm{~h}$, as amostras foram lavadas (3X) em água destilada e o tecido infiltrado em solução crioprotetora (Glicerol $30 \%$ até submersão total). Em seguida, as amostras foram mergulhadas em $\mathrm{N}_{2}$ líquido e foi realizada a fratura das mesmas, depois as amostras foram transferidas para solução de $\mathrm{OsO}_{4}(0,2 \%)$ e deixadas em repouso por 2 dias a $4^{\circ} \mathrm{C}$. Transcorrido o período, as amostras foram lavadas (5X) em água destilada e desidratadas em série crescente de acetona (30\%,50\%, 70\%, 90\% e 100\%), 10 minutos em cada etapa, sendo que a última etapa foi repetida três vezes. Depois, as amostras foram secas ao ponto crítico (CPD 050, Balzers) e metalizadas com ouro (MED 010, Balzers). Finalmente, as amostradas foram montadas em suportes especiais (stubs) e observadas em Microscópio Eletrônico de Varredura (DSM 900, Zeiss).

\subsection{Resultados}

\subsubsection{Avaliação da comunidade bacteriana endofítica de soja}

A metodologia descrita permitiu o isolamento de diferentes grupos bacterianos endofíticos, incluindo Methylobacterium spp., de caule e raiz de soja, durante o estádio de desenvolvimento vegetal R6 (maturação). Além disso, não foi observada a presença de crescimento bacteriano no controle, mostrando que a metodologia de desinfecção superficial eliminou a comunidade epifítica dos tecidos vegetais.

Além de Methylobacterium, foi observada ampla diversidade bacteriana (Figura 1), incluindo Pseudomonas sp., Enterobacter sp., Pantoea sp., Burkholderia sp., Ralstonia sp., Acinetobacter sp., Agrobacterium sp. e Caulobacter sp. e actinomicetos. Entretanto, as análises se concentraram em Methylobacterium spp. 


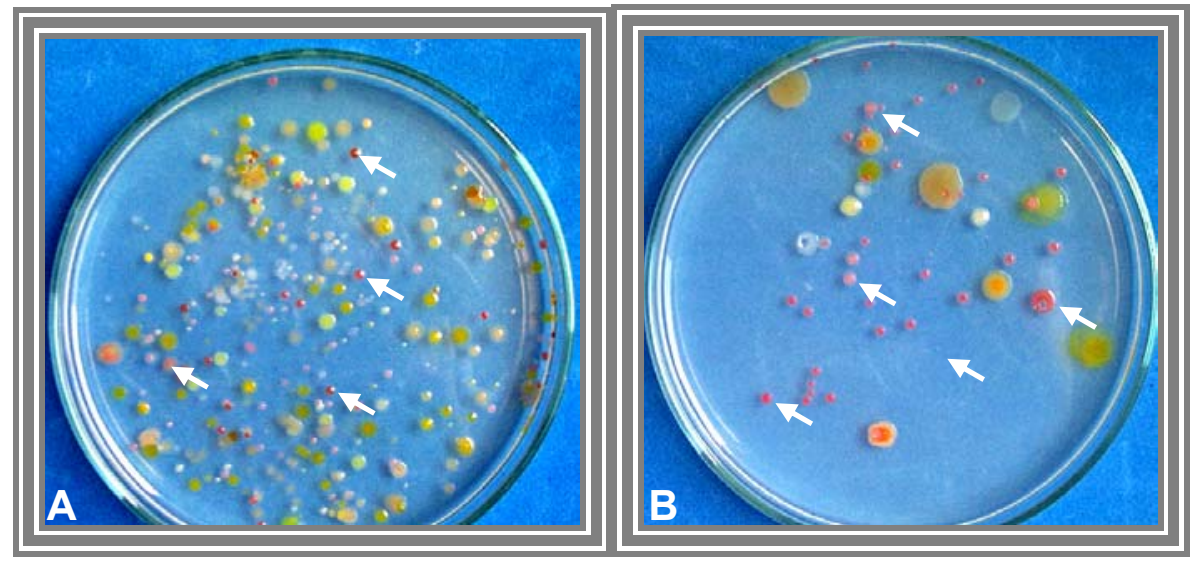

Figura 1 - A e B) Diversidade morfológica de bactérias endofíticas. As colônias de coloração rosa são representantes de Methylobacterium spp. (setas)

A aplicação de glifosato em pré-plantio e a época de coleta (safras de 2000/01 e 2001/02) foram avaliadas no presente trabalho. A densidade total da comunidade bacteriana endofítica de soja variou em torno de $10^{3}$ e $10^{5} \mathrm{UFC} / \mathrm{g}$ TVF para bactérias isoladas de caule e raiz, respectivamente, mostrando que a raiz apresenta maior densidade bacteriana. Entretanto, a densidade de Methylobacterium spp. se manteve estável nos dois tecidos (Figura 2).

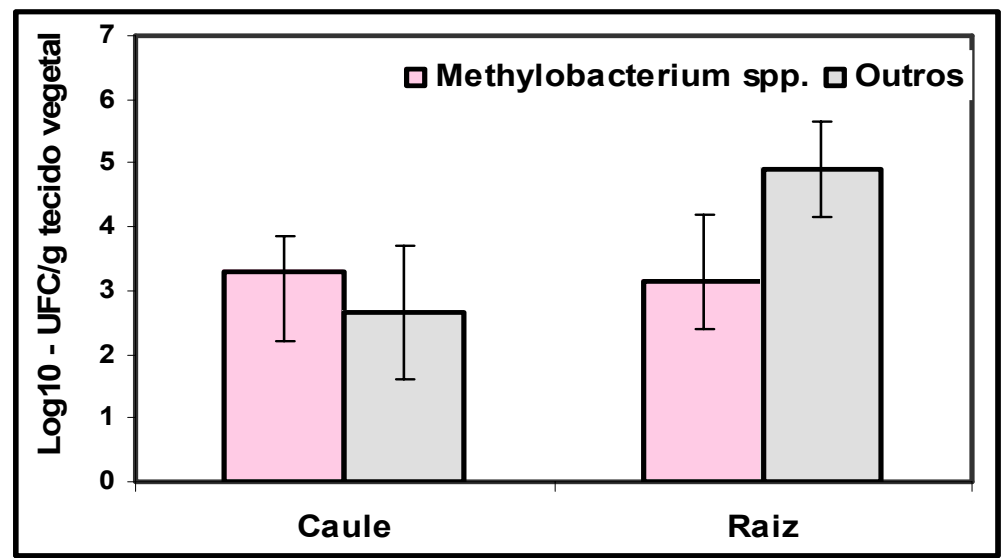

Figura 2 - Densidade populacional bacteriana no caule e raiz de soja. As barras indicam o desvio padrão das médias resultantes da avaliação de 8 plantas 
No caule, a aplicação em pré-plantio do herbicida glifosato não apresentou influência sobre a densidade populacional de Methylobacterium spp. Enquanto que na raiz, este grupo bacteriano foi isolado apenas de plantas crescidas em solo com aplicação do herbicida (Figura 3A). Além disso, a população de Methylobacterium spp. foi significativamente menor nos tecidos radiculares na safra de 2001/02 (Figura 3B).
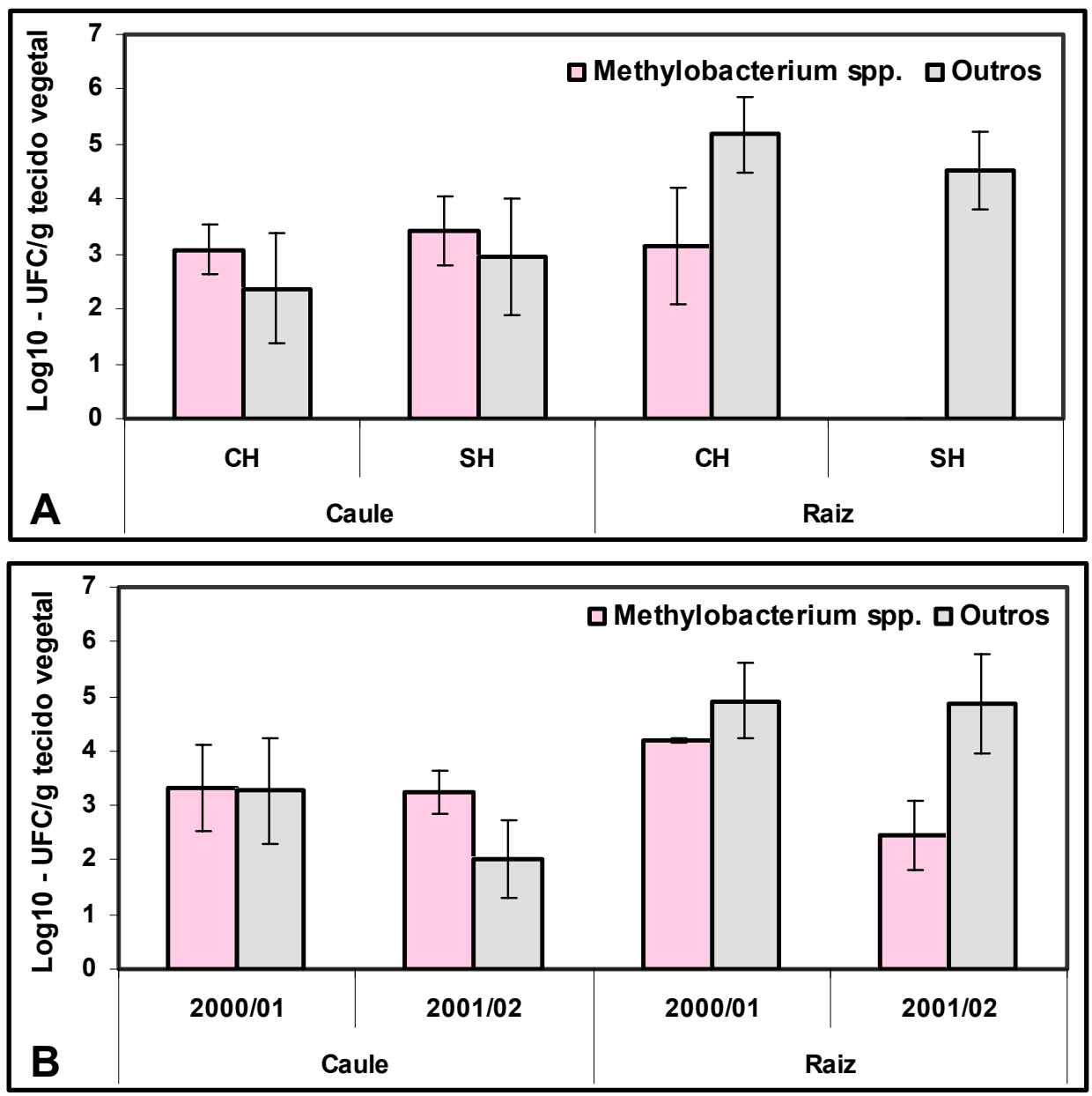

Figura 3 - Densidade populacional bacteriana no caule e raiz de soja. A) Fator: tratamento do solo com aplicação pré-plantio do herbicida glifosato (CH) e sem aplicação do herbicida (SH); B) Fator: safras de 2000/01 e 2001/02. As barras indicam o desvio padrão das médias resultantes da avaliação de 4 plantas (repetições) 


\subsubsection{Avaliação da colonização de soja por Methylobacterium spp.}

As linhagens SR1.6/6 de $M$. mesophilicum e EN29C de Methylobacterium sp., isoladas de caules de citros e soja, respectivamente, foram reinoculadas em sementes e mantidas in vitro, sob condições controladas ( $28^{\circ} \mathrm{C}$ e fotoperíodo de $18 \mathrm{~h}$ luz e por $6 \mathrm{~h}$ escuro), por 15 dias. Todo o preparo das amostras para MEV e utilização do microscópio eletrônico foi realizado no NAP/MEPA - ESALQ/USP (Núcleo de Apoio à Pesquisa/ Microscopia Eletrônica Aplicada à Pesquisa Agropecuária). A técnica de criofratura não foi satisfatória para o preparo das amostras, pois, as mesmas ficaram mal conservadas e com muitos artefatos, impossibilitando a visualização de imagens nítidas, principalmente na região interna dos tecidos. Além disso, foi observado que os tecidos das plântulas apresentaram textura tenra (macia, frágil) no momento do preparo. Entretanto, foi possível realizar a observação sob MEV das amostras submetidas à técnica padrão utilizada no NAP/MEPA.

Foi observado que ambas as linhagens apresentaram a capacidade de colonizar plântulas in vitro e de se translocar da raiz às folhas. Na região da superfície foliar, foi possível registrar a presença da linhagem EN29C ao redor e no interior de estômatos (Figura $4 A ; B$ ). Sendo também, observado que esta linhagem colonizou intensamente $\mathrm{o}$ interior do tecido foliar da planta hospedeira. A linhagem SR1.6/6 também foi observada na superfície foliar (Figura 5) e na região de estômatos, tanto isoladamente (Figura 5 - série $D, E$ ) como na forma de microcolônias envolta por mucilagem (Figura 5F). Microcolônias da linhagem SR1.6/6 também foram observadas na base de pêlos foliares (Figura 5. - série $\mathrm{G}, \mathrm{H}, \mathrm{I}$ ).

A Figura $6(\mathrm{~A}, \mathrm{~B}, \mathrm{C})$ registra a colonização de M. mesophilicum (SR1.6/6) nos tecidos internos da região de transição entre a raiz e o caule. Nestas amostras, foi possível observar que o tecido não foi bem conservado durante o seu preparo, aparentando um aspecto de rasgado. A superfície de sementes inoculadas também foi analisada, sendo possível observar microcolônias de 
Methylobacterium sp. (EN29C) envoltas por mucilagem (Figura 6 - séries D,E e $F, G)$.

A avaliação das amostras vegetais de plântulas não inoculadas foi satisfatória, porque nenhuma estrutura semelhante a células bacterianas (Figura 7) foi encontrada. Além disso, o processo de desinfecção superficial das sementes foi efetivo, pois, a cultura da água da última lavagem das sementes não resultou em crescimento microbiano. 

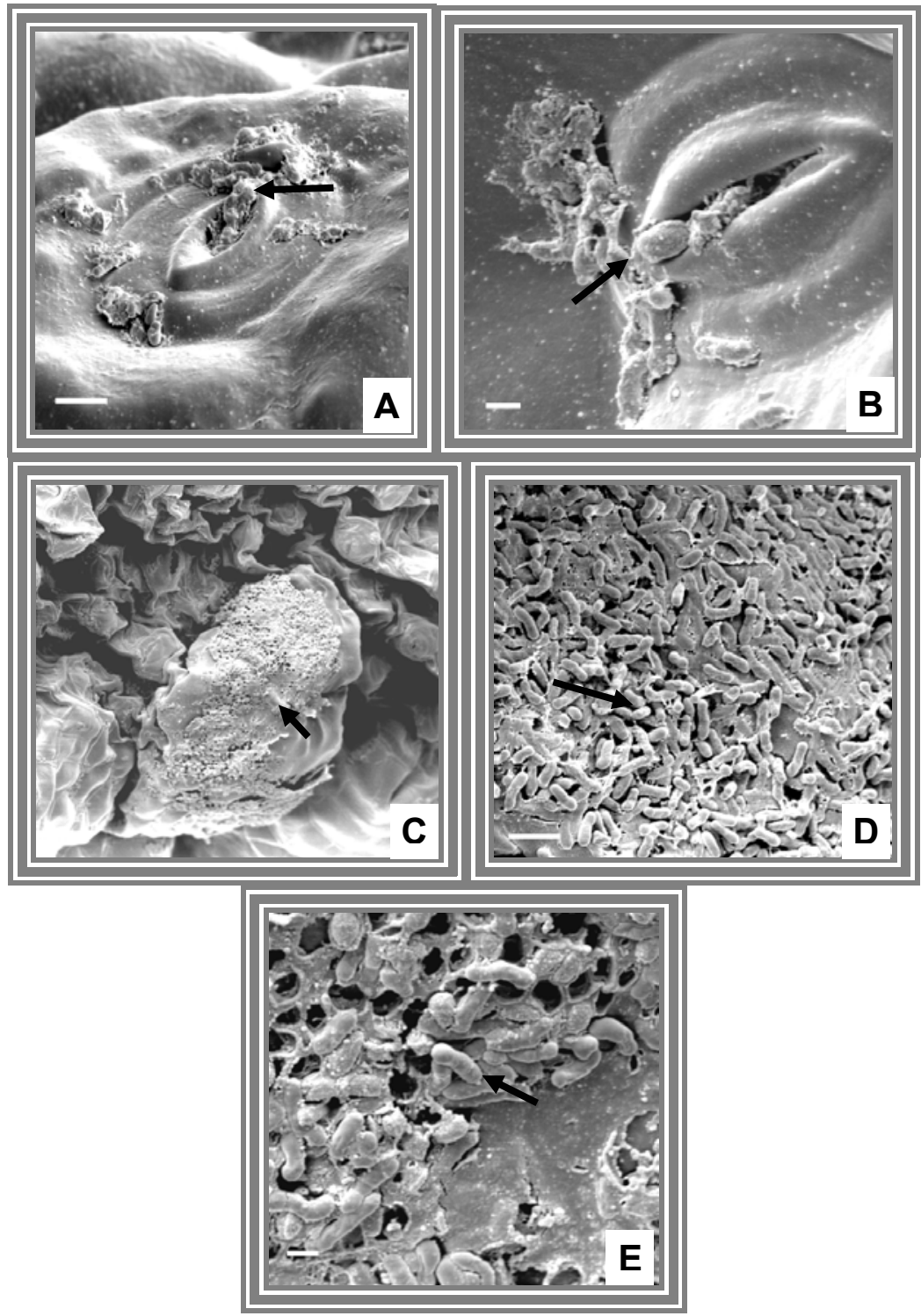

Figura 4 - Colonização de Methylobacterium sp. (EN29C) ao redor de estômatos de folhas [A) Aumento 3.000x (barra = $5 \mu \mathrm{m}$ ); B) Aumento 5.000x (barra $=2 \mu \mathrm{m}$ )] e no interior do tecido foliar [Série: C) Aumento 500x (barra $=20 \mu \mathrm{m}$ ); D) Aumento 2.000x (barra $=5$ $\mu \mathrm{m})$; E) Aumento 5.000x (barra $=2 \mu \mathrm{m})$ ] 


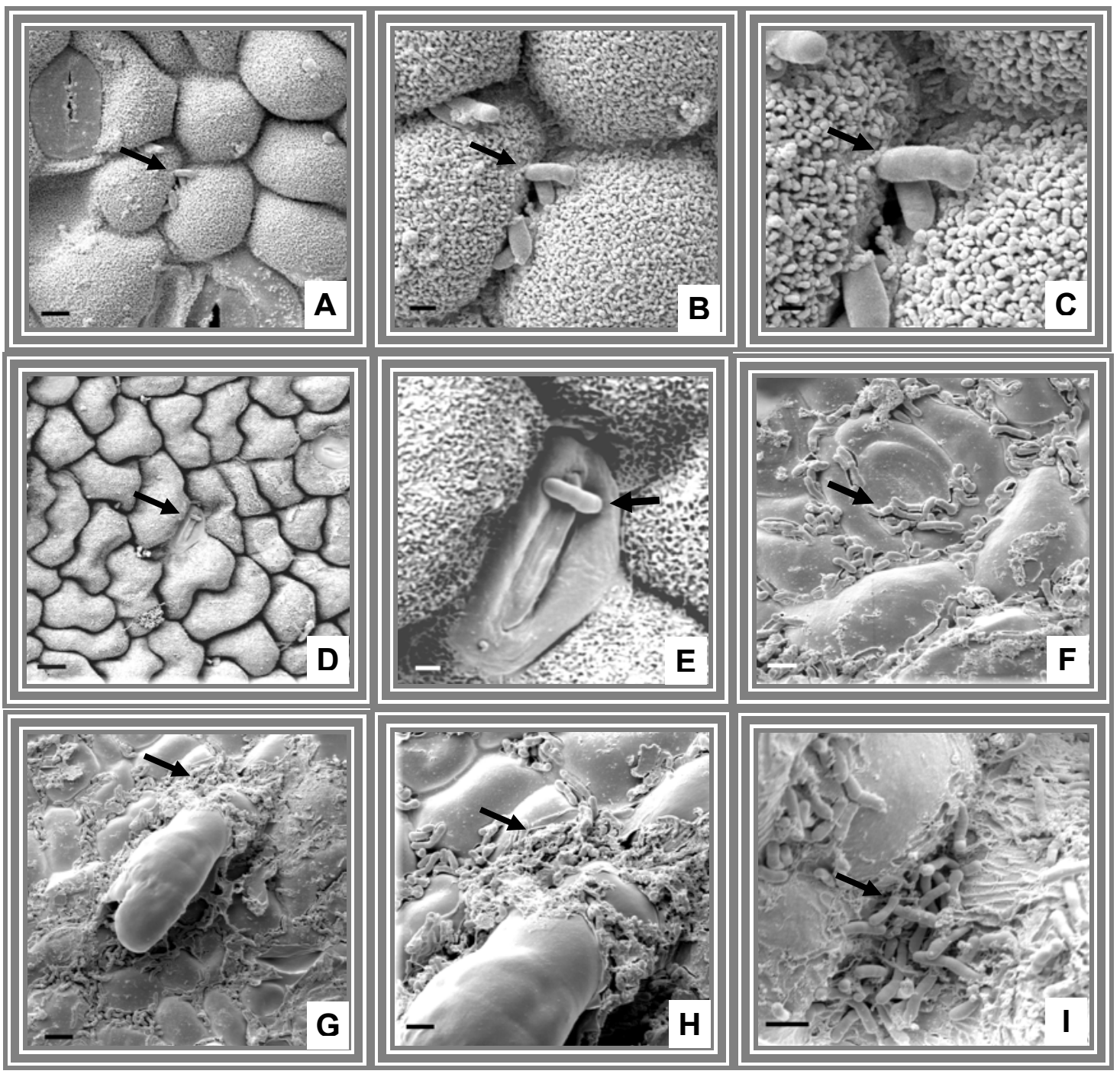

Figura 5 - Colonização de M. mesophilicum (SR1.6/6) na superfície do tecido foliar [Série: A) Aumento 2.000x (barra $=5 \mu \mathrm{m}$ ); B) Aumento 5.000x (barra $=2 \mu \mathrm{m}) ; \mathbf{C})$ Aumento $10.000 x$ (barra $=1 \mu \mathrm{m})$ ], na região dos estômatos de folha [Série: D) Aumento 1.000x (barra = $10 \mu \mathrm{m}$ ); E) Aumento 5.000x (barra $=2 \mu \mathrm{m}$ ) e F) Aumento 3.000x (barra $=5 \mu \mathrm{m})$ ] e na base de pêlos foliares [Série: G) Aumento 2.000x (barra $=5$ $\mu \mathrm{m}) ; \mathbf{H})$ Aumento 1.000x (barra $=10 \mu \mathrm{m}) ;$ I) Aumento 5.000x (barra $=$ $2 \mu \mathrm{m})]$ 

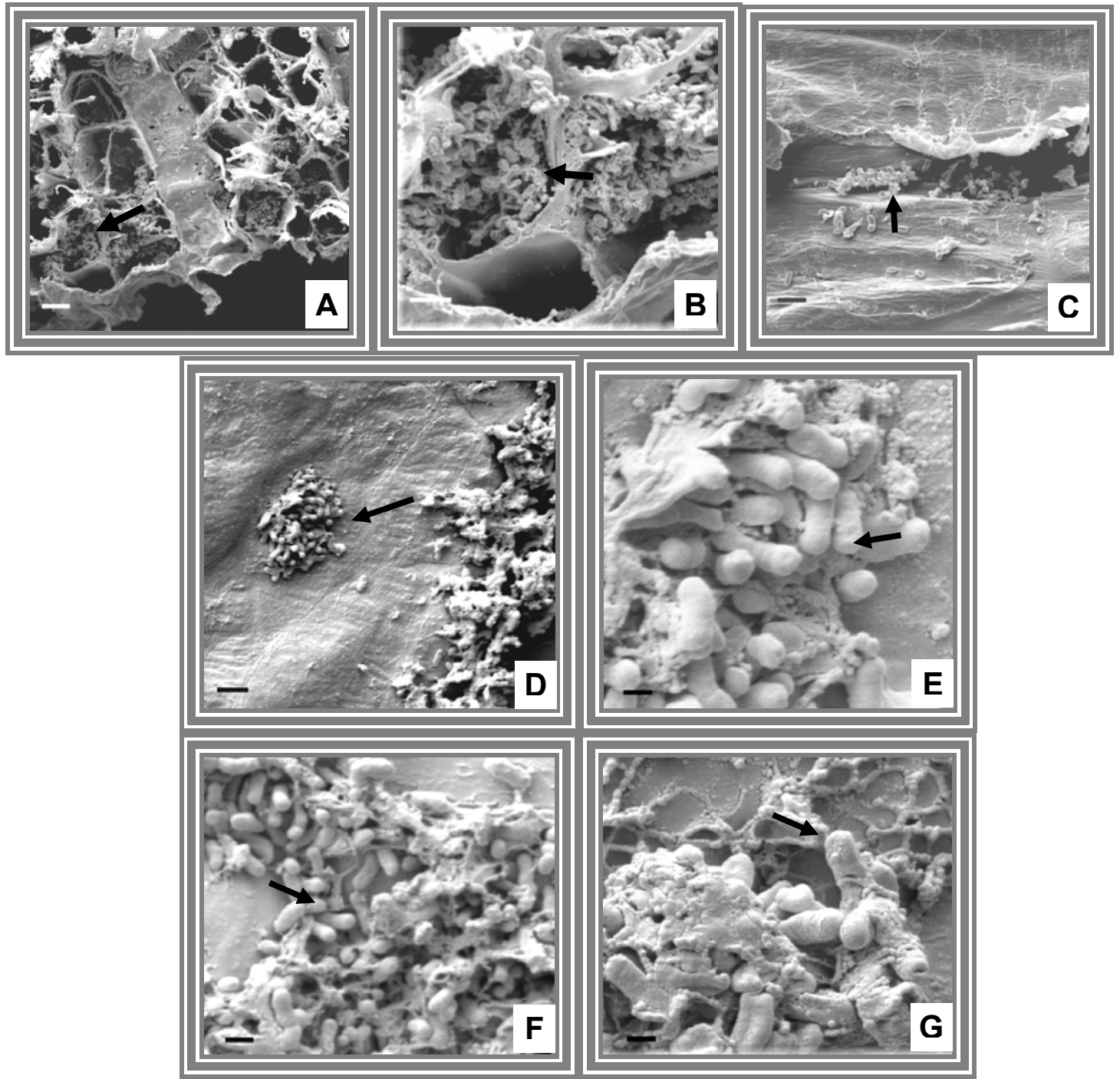

Figura 6 - Colonização de M. mesophilicum (SR1.6/6) no interior de vasos condutores da raiz [A) Aumento 1.000x (barra = $10 \mu \mathrm{m})$; B) Aumento 3.000x (barra $=5 \mu \mathrm{m}$ ); C) Corte horizontal com aumento 2.000x (barra $=5 \mu \mathrm{m})]$ e Methylobacterium sp. (EN29C) colonizando a superfície de sementes inoculadas [D) Aumento 2.000x (barra $=5 \mu \mathrm{m})$; E) Aumento 10.000x (barra = $1 \mu \mathrm{m})$; F) Aumento 5.000x (barra $=2 \mu \mathrm{m})$; G) Aumento 10.000x (barra $=1$ $\mu \mathrm{m})]$ 

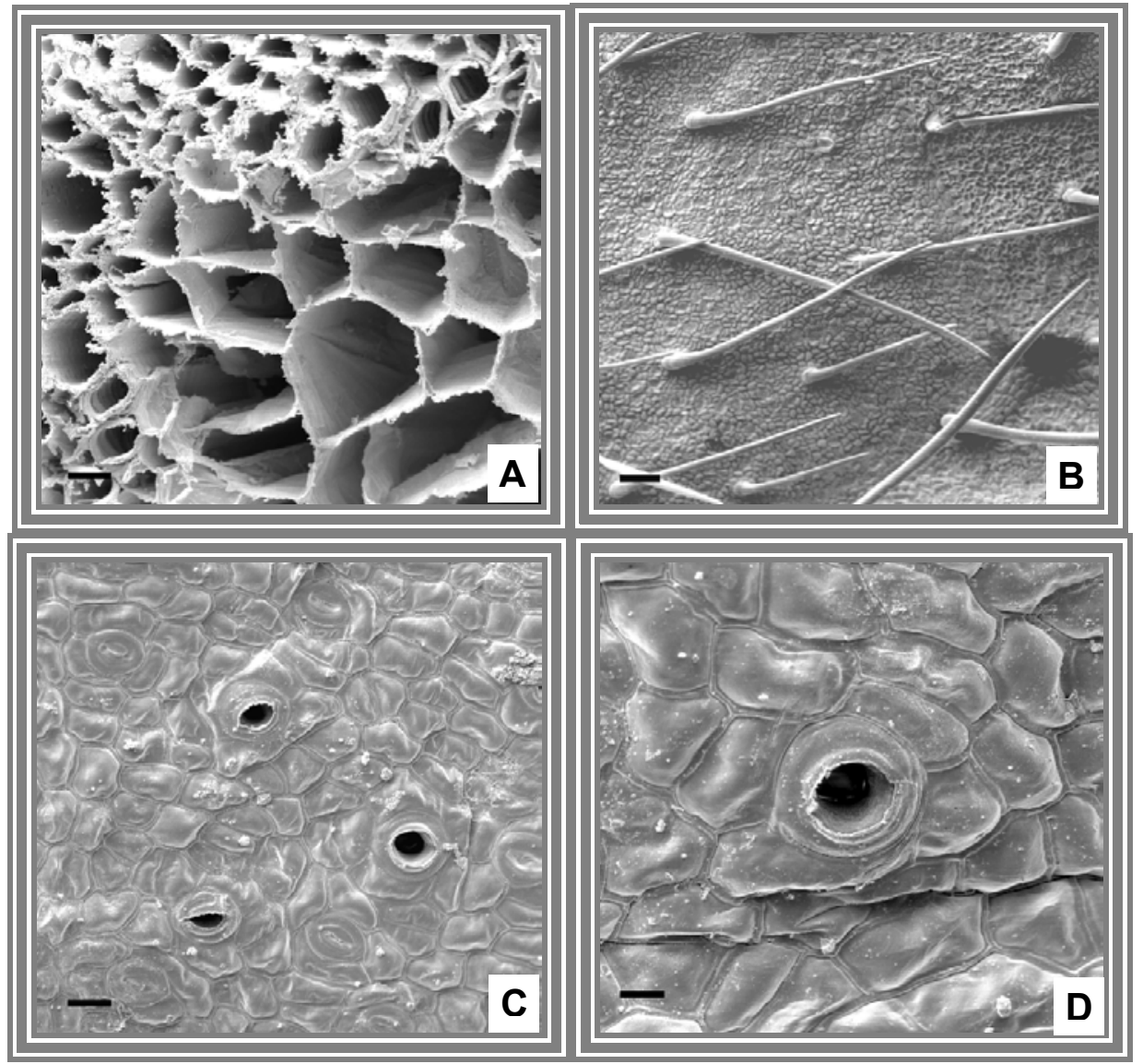

Figura 7 - Amostras não inoculadas (controle). A) Vasos condutores da região do caule [Aumento 500x (barra $=20 \mu \mathrm{m})$ ]; B) Superfície foliar com pêlos [Aumento 100x (barra $=100 \mu \mathrm{m})$ ]; C,D) Superfície foliar com estômatos [Aumentos 500x e 1.000x (barra $=20$ e $10 \mu \mathrm{m}$ ), respectivamente] 


\subsection{Discussão}

Os estudos sobre simbiose entre plantas leguminosas e bactérias associadas geralmente são referentes a rizóbios, bactérias pertencentes ao grupo filogenético $\alpha$-Proteobacteria, Família Rhizobiaceae. Estas bactérias são conhecidas por fixarem nitrogênio atmosférico em nódulos (estruturas vegetais desenvolvidas a partir da interação destas bactérias com as plantas) e, também, como fertilizantes naturais na produção agrícola de leguminosas (Quispel, 1988; Bloemberg et al., 2001; Jensen \& Hauggaard-Nielsen, 2003). Contudo, Sy et al. (2001) descreveram uma nova espécie bacteriana, Methylobacterium nodulans, envolvida na formação de nódulos e fixação de nitrogênio em Crotalaria (leguminosa), sugerindo que outros gêneros bacterianos podem apresentar um papel importante no suprimento de $\mathrm{N}_{2}$ para estas plantas.

O gênero Methylobacterium pertence à Ordem Rhizobiales, mas à Família Methylobacteriaceae, mostrando filogenia com a família Rhizobiaceae. Bactérias deste gênero apresentam coloração rósea e são metilotróficas facultativas (PPFMs - pink-pigment facultatively methylotrophic), sendo encontradas em relações epifíticas e endofíticas com diferentes espécies vegetais (Holland \& Polacco, 1994; Sy et al., 2001; Araújo et al., 2001; Araújo et al., 2002; Koenig et al., 2002). Em soja, foi observado que a presença Methylobacterium spp. estimula a germinação das sementes, porém, os mecanismos envolvidos ainda não são conhecidos (Holland \& Polacco, 1994; Koenig et al., 2002).

Em experimentos anteriores (capítulos 3, 4 e 5), Methylobacterium spp. endofíticas não foram isoladas quando o fungicida imazalil foi utilizado. Entretanto, no presente trabalho, utilizando benomyl como fungicida, foi observado Methylobacterium spp. em alta densidade. Tal fato sugere que esta bactéria seja sensível ao fungicida Imazalil. Este fungicida é pertencente ao grupo dos imidazóis e atua inibindo a biossíntese dos precursores do ergosterol 
(componentes das estruturas das membranas celulares). Além disso, este fungicida é muito utilizado no controle de doenças pós-colheitas de frutas, tais como citros, banana, mamão papaia e manga (www.arua.com.br/magnate.htm). Thirup et al. (2001) analisaram o efeito do imazalil sobre dois grupos bacterianos do solo, Pseudomonas e actinomicetos, e observaram que este fungicida afetou provisoriamente o grupo de Pseudomonas. Portanto, diante das observações gerais do presente trabalho, pode-se inferir que o imazalil apresenta algum efeito inibitório sobre o crescimento de Methylobacterium spp., tendo como conseqüência, alteração na freqüência de isolamento destas bactérias endofíticas.

A colonização e distribuição de bactérias endofíticas no hospedeiro podem ser influenciadas por interações com outros microrganismos associados à planta, nematóides parasitas, e pelo próprio tipo de interação com seu hospedeiro (Lindow \& Andersen, 1996; Quadt-Hallmann et al., 1997b; Hirano \& Hupper, 2000). Neste contexto, o habitat associado à planta é um ambiente dinâmico, no qual diversos fatores podem influenciar a estrutura e composição da comunidade bacteriana associada a esta. No presente trabalho, foi observado também que populações endofíticas de Methylobacterium, da raiz, sofreu efeitos da aplicação de glifosato e da época de cultivo. Isto pode ter ocorrido devido ao fato da raiz ser a região da planta que está em contato direto com o solo, tendo, portanto, maior número e diversidade de microrganismos associados e influenciados por fatores ambientais. Araújo (2000) também observou que variações sazonais influenciaram populações endofíticas de Methylobacterium spp., isoladas de citros. Mocali et al. (2003) avaliaram diferentes fatores bióticos e abióticos sobre a flutuação de populações bacterianas endofíticas em olmeiro (Ulmus japonica), observando que fatores como temperatura, estação do ano e tecido vegetal influenciaram a freqüência de diferentes bactérias endofíticas.

Nos estudos de interação endófitos-hospedeiro, a microscopia eletrônica é um poderoso instrumento, por permitir localizar e caracterizar o 
microrganismo dentro do seu hospedeiro vegetal ou aderido a sua superfície. O modo de penetração ou adesão, a colonização do hospedeiro e as alterações mutuamente induzidas são alguns aspectos que podem ser caracterizados por meio deste instrumento (James \& Olivares, 1997; Nogueira \& Barroso, 1998). A microscopia eletrônica de varredura convencional (MEV) tem sido satisfatoriamente usada para detectar endófitos em várias plantas, incluindo milho, trigo, arroz, cana-de-açúcar e citros (James et al., 1994; James \& Olivares, 1997; Quadt-Hallmann et al, 1997b; Reinhold-Hurek \& Hurek, 1998; Gai et al., 2000). A MEV possibilitou a observação de microcolônias de Methylobacterium spp. na região basal de pêlos foliares e na periferia dos estômatos de soja, fato este que reforça a hipótese destes pontos poderem ser utilizados por bactérias endofíticas para a entrada na planta hospedeira. Neste contexto, tem sido descrito que estas regiões, juntamente com ferimentos, áreas de emergências de raízes laterais e produção de enzimas hidrolíticas capazes de degradar a parede celular dos vegetais, possam ser possíveis caminhos de penetração das bactérias endofíticas (Ruppel et al, 1992; Di-Fiore \& Del-Gallo, 1995; Quadt-Hallmann et al, 1997a; Sturz et al., 2000).

Devido à significativa presença e capacidade de interação com diferentes tecidos de soja, é possível especular que o gênero Methylobacterium apresente significativa interação com este hospedeiro, inclusive por meio de mecanismos de promoção de crescimento vegetal, visto que esta espécie é capaz de fixar nitrogênio atmosférico, possuir genes de nodulação e produzir o fitohormônio citocinina (Holland, 1997; Sy et al., 2001; Koenig et al., 2002), mostrando a importância desta bactéria no desenvolvimento vegetal. 


\subsection{Conclusões}

Os resultados apresentados permitem concluir que:

a) o gênero Methylobacterium faz parte da comunidade bacteriana endofítica de soja;

b) a colonização endofítica de Methylobacterium spp. em caule e raiz de soja foi influenciada pela aplicação (pré-plantio) do herbicida glifosato e por variações sazonais;

c) linhagens endofíticas de Methylobacterium são capazes de colonizar sistemicamente plântulas de soja (in vitro) inoculadas via semente. 


\section{CONCLUSÕES GERAIS}

A presente pesquisa teve como objetivo geral o estudo da comunidade bacteriana associada à soja (Glycine max), bem como, estudar os mecanismos envolvidos na interação bactéria-planta. Desta forma, com base nos resultados obtidos, as seguintes conclusões podem ser apresentadas:

a) Fatores, tais como, tratamento do solo com aplicação pré-plantio do herbicida glifosato, estádios fenológicos do hospedeiro, variações do genótipo e tecidos da planta podem influenciar a densidade populacional, diversidade genética e fisiológica de bactérias endofíticas e epifíticas;

b) O grupo bacteriano Proteobacteria é predominante entre as bactérias associadas à soja, sendo representado principalmente pelos gêneros Pseudomonas, Burkholderia, Ralstonia, Acinetobacter, Enterobacter, Pantoea e Methylobacterium;

c) Isolados bacterianos endofíticos e epifíticos apresentam potencial aplicação biotecnológica como promotores de crescimento vegetal, pois, expressaram a capacidade de produzir auxina, solubilizar fosfato inorgânico e fixar nitrogênio atmosférico;

d) A cultivar Foscarin (ciclo precoce) apresenta maior população de bactérias epifíticas produtoras de auxina; 
e) A bactéria Burkholderia gladioli, que apresentou alta variabilidade genética, está associada à degradação do herbicida glifosato;

f) Methylobacterium spp. endofíticas apresentam a capacidade de colonizar sistemicamente plântulas de soja, quando inoculadas em sementes;

g) Linhagens de bactérias endofíticas promoveram o aumento do peso de raiz e da parte aérea de plântulas de soja quando reintroduzidas via semente, demonstrando que a interação endófito-planta pode trazer benefícios para o hospedeiro, que pode resultar no aumento da produtividade destas plantas;

h) O possível aumento da utilização do herbicida glifosato poderá alterar a comunidade bacteriana associada à soja com potencial aplicação biotecnológica e benéfica para a planta hospedeira.

Finalmente, os resultados obtidos no presente trabalho contribuíram para um melhor entendimento da interação bactéria-planta, abrindo perspectivas para a utilização destas bactérias em programas de melhoramento genético de soja, com incremento do crescimento vegetal e produção de grãos. 


\section{REFERÊNCIAS BIBLIOGRÁFICAS}

ALVES, B.R.J.; BODDEY, R.M.; URQUIAGA, S. The success of BNF in soybean in Brazil. Plant and Soil, v.252, p.1-9, 2003.

AMANN, R.I.; LUDWIG, W.; SCHLEIFER, K.H. Phylogenetic identification and in situ detection of individual microbial cells without cultivation. Microbiological Reviews, v.59, p.143-169, 1995.

AMARANTE-JR, O.P.; SANTOS, T.C.R.; BRITO, N.M.; RIBEIRO, M.L. Métodos de extração e determinação do herbicida glifosato: breve revisão. Química Nova, v.25, p.420-428, 2002a.

AMARANTE-JR, O.P.; SANTOS, T.C.R.; BRITO, N.M.; RIBEIRO, M.L. Glifosato: propriedades, toxicidade, usos e legislação. Química Nova, v.25, p.589-593, 2002b.

ANDREWS, J.H. Biological control in the phyllosphere. Annual Reviews in Phytopathology, v.30, p.603-635, 1992.

ANDREWS, J.H.; HARRIS, R.F. The ecology and biogeography of microorganisms on plant surfaces. Annual Reviews of Phytopathology, v.38, p.145-180, 2000.

ARAÚJO, J.M.; SILVA, A.C.; AZEVEDO, J.L. Isolation of endophytic actinomycetes from roots and leaves of maize (Zea mays L.). Brazilian Archives of Biology and Technology, v.43, p.447-451, 2000. 
ARAÚJO, W.L. A comunidade bacteriana endofítica de citros e sua interação com Xilella fastidiosa, agente causal da clorose variegada dos citros (CVC). Piracicaba, 2000. 131p. Tese (Doutorado) - Escola Superior de Agricultura "Luiz de Queiroz" - Universidade de São Paulo.

ARAÚJO, W.L.; MACCHERONI JR, W.; AGUILAR-VILDOSO, C.I.; BARROSO, P.A.V.; SARIDAKIS, H.O.; AZEVEDO, J.L. Variability and interactions between endophytic bacteria and fungi isolated from leaf tissues of citrus rootstocks. Canadian Journal of Microbiology, v.47, p.229-236, 2001.

ARAÚJO, W.L.; MARCON, J.; MACCHERONI JR, W.; VAN ELSAS, J.D.; VAN VUURDE, J.W. L.; AZEVEDO, J.L. Diversity of endophytic bacterial populations and their interaction with Xylella fastidiosa in citrus plants. Applied and Environmental Microbiology, v.68, p.4906-4914, 2002.

ARSHAD, M; FRAKENBERGER-JR, W.T. Plant growth-regulating substances in the rhizosphere: microbial production and functions. Advances in Agronomy, v.62, p.45-151, 1998.

AZEVEDO, J.L. Microrganismos endofíticos. In: MELO, I.S.; AZEVEDO, J.L. (Ed.) Ecologia Microbiana. Jaguariúna: EMBRAPA-Meio Ambiente, 1998a. cap.4, p.117-137.

AZEVEDO, J.L. Biodiversidade microbiana e potencial biotecnológico. In: MELO, I.S.; AZEVEDO, J.L. (Ed.) Ecologia Microbiana. Jaguariúna: EMBRAPA-Meio Ambiente, 1998b. cap.18, p.445-461.

AZEVEDO, J.L.; ARAÚJO, W.L. Genetically modified crops: environmental and human health concerns. Mutation Research, v.544, p.223-233, 2003. 
AZEVEDO, J.L.; ARAÚJO, W.L.; MACCHERONI-JR, W. Importância dos microrganismos endofíticos no controle de insetos. In: MELO, I.S.; AZEVEDO, J.L. (Ed.) Controle Biológico. Jaguariúna: EMBRAPA-Meio Ambiente, 2000a. cap.3, p.57-93.

AZEVEDO, J.L.; MACCHERONI JR, W.; PEREIRA, J.O.; ARAÚJO, W.L. Endophytic microrganisms: a review on insect control and recent advences on tropical plants. Eletronic Journal of Biotechnology, v.3, 2000b. http://www.ejb.org/content/vol3/issuel/full/3/4 (05/05/2000).

BAI, Y.M.; D'AOUST, F.; SMITH, D. L.; DRISCOLL, B. T. Isolation of plantgrowth-promotion Bacillus strains from soybean root nodules. Canadian Journal of Microbiology, v.48, p.230-238, 2002.

BAI, Y.M.; ZHOU, X.M.; SMITH, D.L. Enhanced soybean plant growth resulting from coinoculation of Bacillus strains with Bradyrhizobium japonicum. Crop Science, v.43, p.1774-1781, 2003.

BARROTI, G.; NAHAS, E. População microbiana total e solubilizadora de fosfato em solo submetido a diferentes sistemas de cultivo. Pesquisa Agropecuária Brasileira, v.35, p.2043-2050, 2000.

BARTH, A.C.J.; SLATER, G.; SCHÜTH, C.; BILL, M.; DOWNEY, A.; LARKIN, M.; KALIN, R.M. Carbon isotope fractionation during aerobic biodegradation of trichloroethene by Burkholderia cepacia G4: a tool to map degradation mechanisms. Applied and Environmental Microbiology, v.68, p.17281734, 2002.

BARY, A. Morphologie und physiologie der Pilze, Flechten und Myxomyceten. Leipzig: Engelamn, 1866, 316p. 
BASTIÁN, F.; COHEN, A.; PICCOLI, P.; LUNA, V.; BARALDI, R.; BOTTINI, R. Production of indole-3-acetic acid and gibberellin $A_{1}$ and $A_{3}$ by Acetobacter diazotrophicus and Herbaspirillum seropedicae in chemically-defined culture media. Plant Growth Regulation, v.24, p.7-11, 1998.

BELIMOV, A.A.; SAFRONOVA, V.I.; SERGEYEVA, T.A.; EGOROVA, T.N.; MATVEYEVA, V.A.; TSYGANOV, V.E.; BORISOV, A.Y.; TIKHONOVICH, I.A.; KLUGE, C.; PREISFELD, A.; DIETZ, K.J.; STEPANOK, V.V. Characterization of plant growth promoting rhizobacteria isolated from polluted soils and containing 1-aminocyclopropane-1-carboxylate deaminase. Canadian Journal of Microbiology, v.47, p.642-652, 2001.

BELL, C.R.; DICKIE, G.A.; HARVEY, W.L.G.; CHAN, J.W.Y.F. Endophytic bacteria in grapevine. Canadian Journal Microbiology, v.41, p.46-53, 1995.

BEVIVINO, A.; SARROCCO, S.; DALMASTRI, C.; TABACCHIONI, S.; CANTALE, C.; CHIARINI, L. Characterization of a free-living maizerhizosphere population of Burkholderia cepacia: effect of seed treatment on disease suppression and growth promotion of maize. FEMS Microbiology Ecology, v.27, p.225-237, 1998.

BLOEMBERG, G.V.; LUGTENBERG, B.J.J. Molecular basis of plant growth promotion and biocontrol by rhizobacteria. Current Opinion in Plant Biology, v.4, p.343-350, 2001.

BODDEY, R.M.; URQUIAGA, S.; ALVES, B.J.R.; REIS, V. Endophytic nitrogen fixation in sugracane: present knowledge and future applications. Plant and Soil, v.252, p.139-149, 2003. 
BORÉM, A. Escape gênico: os riscos do escape gênico da soja no Brasil. Biotecnologia Ciência \& Desenvolvimento, v.10, p.101-107, 1999.

BRIC, J.M.; BOSTOCK, R.M.; SILVERSTONE, S. Rapid in situ assay for indoleacetic acid production by bacteria immobilized on a nitrocellulose membrane. Applied and Environmental Microbiology, v.57, p.535-538, 1991.

BRIM, H.; HEUER, H.; KRÖGERRECKLENFORT, E.; MERGEAY, M.; SMALLA, K. Characterization of bacterial community of a zinc-polluted soil. Canadian Journal of Microbiology, v.45, p.326-338, 1999.

BUSSE, M.D.; RATCLIFF, A.W.; SHESTAK, C.J.; POWERS, R.F. Glyphosate toxicity and the effects of long-term vegetation control on soil microbial communities. Soil Biology \& Biochemistry, v.33, p.1777-1789, 2001.

CARLISLE, S.M.; TREVORS, J.T. Glyphosate in the environment. Water, Air, and Soil Pollution, v.39, p.409-420, 1988.

CASSÁN, F.D.; LUCANGELI, C.D.; BOTTINI, R.; PICCOLI, P.N. Azospirillum spp. Metabolize $\left[17,17-{ }^{2} \mathrm{H}_{2}\right]$ gibberellin $\mathrm{A}_{20}$ to $\left[17,17-{ }^{2} \mathrm{H}_{2}\right]$ gibberellin $\mathrm{A}_{1}$ in vivo in $d y$ ice mutant seedlings. Plant Cell Physiology, v.42, p.763-767, 2001.

CAVALCANTE, V.A.; DOBEREINER, J. A new acid-tolerant nitrogen-fixing bacterium associated with sugarcane. Plant and Soil, v.108, p.23-31, 1988.

CHABOT, R.; BEAUCHAMP, C.J.; KLOEPPER, J.W.; ANTOUN, H. Effect of phosphorous on root colonization and growth promotion of maize by bioluminescent mutants of phosphate-solubilizing Rhozobium leguminosarum biovar phaseoli. Soil Biology and Biochemistry, v.30, p.1615-1618, 1998. 
CHANWAY, C.P. Bacterial endophytes: ecological and practical implications. Sydowia, v.50, p.149-170, 1998.

CHELIUS, M.K.; TRIPLETT, E.W. Immunolacalization of dinitrogenase reductase produced by Klebsiella pneumoniae in association with Zea mays L. Applied and Environmental Microbiology, v.66, p.783-787, 2000.

CHELIUS, M.K.; TRIPLETT, E.W. The diversity of archaea and bacteria in association with the roots of Zea mays L. Microbial Ecology, v.41, p.252263, 2001.

CHENEBY, D.; PHILIPPOT, L.; HARTMANN, A.; HENAULT, C.; GERMON, J.C. $16 \mathrm{~S}$ rDNA analysis for characterization of denitrifying bacteria isolated from three agricultural soils. FEMS Microbiology Ecology, v.34, p.121-128, 2000.

COCKING, E. Endophytic colonization of plant roots by nitrogen-fixing bacteria. Plant and Soil, v.252, p.169-175, 2003.

COLWELL, R. Microbial diversity: the importance of exploration and conservation. Journal of Industrial Microbiology and Biotechnology, v.18, p.302-307, 1997.

CRECCHIO, A.; CURCI, M.; PIZZIGALLO, M.D.R.; RICCIUTI, P.; RUGGIERO, P. Molecular approaches to investigate herbicide-induced bacterial community changes in soil microcosms. Biology and Fertility of Soils, v.33, p.460-466, 2001.

CROZIER, A.; ARRUDA, P.; JASMIM, J.M.; MONTEIRO, A.M.; SANDBERG, G. Analysis of indole-3-acetic acid and related indoles in culture medium from Azospirillum lipoferum and Azospirillum brasiliense. Applied and Environmental Microbiology, v.54, p.2833-2837, 1988. 
CRUZ, L.M.; SOUZA, E.M.; WEBER, O.B.; BALDANI, J.I.; DOBEREINER, J.; PEDROSA, F.O. 16S ribosomal DNA characterization of nitrogen-fixing bacteria isolated from banana (Musa sp.) and pineapple (Ananas comosus (L.) Merril). Applied and Environmental Microbiology, v.67, p.2375-2379, 2001.

DALMASTRI, C.; CHIARINI, L.; CANTALE, C.; BEVIVINO, A.; TABACCHIONO, $S$. Soil type and maize cultivar affect the genetic diversity of maize rootassociated Burkholderia cepacia populations. Microbial Ecology, v.38, p.273-284, 1999.

DESAINT, S.; HARTMANN, A.; PAREKH, N.R.; FOURNIER, J.C. Genetic diversity of carbofuran-degrading soil bacteria. FEMS Microbiology Ecology, v.34, p.173-180, 2000.

DICK, R.E.; QUINN, J.P. Glifosato-degrading isolates from environmental samples: occurrence and pathways of degradation. Applied Microbiological and Biotechnology, v.43, p.545-550, 1995.

DI-FIORE, S.; DEL-GALLO, M. Endophytic bacteria: their possible role in the host plant. Azospirillu VI and Related Microorganisms, v.G37, p.169-187, 1995.

DOBBELAERE, S.; CROONENBORGHS, A.; THYS, A.; BROEK, A.V.; VANDERLEYDEN, J. Phytostimulatory effect of Azospirillum brasiliense wild type and mutant strains altered in IAA production on wheat. Plant and Soil, v.212, p.155-164, 1999.

DOBEREINER, J. Recent changes in concepts of plant bacteria interactions: endophytic $\mathrm{N}_{2}$ fixing bacteria. Ciência e Cultura, v.44, p.310-313, 1992. 
DOBEREINER, J.; URQUIAGA, S.; BODDEY, R.M. Alternatives for nitrogen of crops in tropical agriculture. Fertilizer Research, v.42, p.339-346, 1995.

DOTSON, S.B.; LANAHAN, M.B.; SMITH, A.G.; KISHORE, G.M. A phosphonate monoester hydrolase from Burkholderia caryophilli PG2982 is useful as a conditional lethal gene in plants. The Plant Journal, v.10, p.383-392, 1996.

DOWNING, K.J.; LESLIE, G.; THOMSON, J.A. Biocontrol of the sugarcane borer Eldana saccharina by expression of the Bacillus thuringiensis cry1Ac7 and Serratia marcescens chiA genes in sugarcane-associated bacteria. Applied and Environmental Microbiology, v.66, p.2804-2810, 2000.

DUSSART, L.; DUPONT, J.P.; ZIMMERLIN, I.; LACROIX, M.; SAITER, J.M.; JUNTER, G.A.; JOUENNE, T. Occurrence of sessile Pseudomonas oryzihabitans from a karsti.ed chalk aquifer Water Research, v. 37, p.15931600, 2003.

DWORKIN, M.; FOSTER, J.W. Experiments with some microorganisms which utilize ethane and hydrogen. Microbiology, v.75, p.502-603, 1958.

EGENER, T.; HUREK, T.; REINHOLD-HUREK, B. Endophytic expression of nif genes of Azoarcus sp. Strain BH72 in rice roots. Molecular Plant-Microbe Interactions, v.12, p.813-819, 1999.

EHMANN, A. The van urk-Salkowski reagent - a sensitive and specific chromogenic reagent for silica gel thin-layer chromatographic detection and identification of indole derivatives. Journal of Chromatography, v.132, p.267-276, 1977. 
ELBELTAGY, A.; NISHIOKA, K.; SATO, T.; SUZUKI, H. YE, B.; HAMADA, T.; ISAWA, T.; MITSUI, H.; MINAMISAWA, K. Endophytic colonization and in planta nitrogen fixation by a Herbaspirillum sp. isolated from wild rice species. Applied and Environmental Microbiology, v.67, p.5285-5293, 2001.

ELVIRA-RECUENCO, M.; VAN VUURDE, J.W.L. Natural incidence of endophytic bacteria in pea cultivars under field conditions. Canadian Journal of Microbiology, v.46, p.1036-1041, 2000.

EMBRAPA/SOJA: http://www.cnpso.embrapa.br (08/11/2003)

FANTROUSSI, S.E.L; VERSCHUERE, L.; VERSTRAETE, W.; TOP E.M. Effect of phenylurea herbicides on soil microbial communities estimated by analysis of 16S rRNA gene fingerprints and community-level physiological profiles. Applied and Environmental Microbiology, v.65, p.982-988, 1999.

FISHER, P.J.; PETRINI, O.; SCOTT, H.M.L. The distribution of some fungal and bacterial endophytes in maize (Zea mays L.). New Phytologist, v.122, p.299-305, 1992.

FORLANI, G.; MANGIAGALLI, A.; NIELSEN, E.; SUARDI, C.M. Degradation of the phosphonate herbicide glifosato in soil: evidence for a possible involvement of unculturable microorganisms. Soil Biology \& Biochemistry, v.31, p.991-997, 1999.

FRANKLIN, R.B.; TAYLOR, D.R.; MILLS, A.L. Characterization of microbial communities using randomly amplified polymorphic DNA (RAPD). Journal of Microbiological Methods, v.35, p.225-235, 1999. 
FROMIN, N.; ACHOUAK, W.; THIERY, J.M.; HEULIN, T. The genotypic diversity of Pseudomonas brassicacearum populations isolated from roots of Arabidopsis thaliana: influence of plant genotype. FEMS Microbial Ecology, v.37, p.21-29, 2001.

FUENTES-RAMIREZ, L.E.; JIMENEZ-SALGADO, T.; ABARCA-OCAMPO, I.R.; CABALLERO-MELLADO, J. Acetobacter diazotrophicus, an indoleacetic acid producing bacterium isolated from sugarcane cultivars of Mexico. Plant and Soil, v.154, p.145-150, 1993.

GAI, C.S.; MACCHERONI, W.; ARAÚJO, W., AZEVEDO, J.L. Genetic variability and localization by scanning electron microscopy of endophytic yeast from citrus (Citrus sinensis). In: CONGRESSO NACIONAL DE GENÉTICA, 46, Águas de Lindóia, 2000. Resumos. Águas de Lindóia: SBG, 2000. p.335.

GARBEVA, P.; VAN OVERBEEK, L.S.; VAN VUURDE, J.W.L.; VAN ELSAS J.D. Analysis of endophytic bacterial communities of potato by plating and denaturing gradient gel electrophoresis (DGGE) of 16S rDNA based PCR fragments. Microbial Ecology, v.41, p.369-383, 2001.

GARG, S.K.; BHATNAGAR, A.; KALLA, A.; NARULA, N. In vitro fixation, phosphate solubilization, survival and nutrient release by Azotobacter strains in an aquatic system. Bioresource Technology, v.80, p.101-109, 2001.

GLICK, B.R. The enhancement of plant growth by free-living bacteria. Canadian Journal of Microbiology, v.41, p.109-117, 1995.

GOLDSTEIN, A.H.; BRAVERMAN, K.; OSORIO, N. Evidence for mutualism between a plant growing in a phosphate-limited desert environment and a mineral phosphate solubilizing (MPS) rhizobacterium. FEMS Microbiology Ecology, v.30, p.295-300, 1999. 
GOMES, P. A soja. 5.ed. São Paulo: Nobel,1990. 152p.

GONÇALVES E.R.; ROSATO, Y.B. Genotypic characterization of Xanthomonas strains isolated from passion fruit plants (Passiflora spp.) their relatedness to different Xanthomonas species. International Journal of Systematic and Evolutionary Microbiology, v.50, p.811-821, 2000.

GYANESHWAR, P.; JAMES, E.K.; MATHAN, N.; REDDY, P.M.; REINHOLDHUREK, B.; LADHA, J.K. Endophytic colonization of rice by a diazotrophic strain of Serratia marcescens. Journal of Bacteriology, v.183, p.26342645, 2001.

GYANESHWAR, P.; KUMAR, G.N.; PAREKH, L.J.; POOLE, P.S. Role of soil microorganisms in improving $P$ nutrition of plants. Plant and Soil, v.245, p.83-93, 2002.

HALLMANN, J.; KLOEPPER, J.W.; RODRIGUEZ-KABAN, R. Application of the Scholander pressure bomb to studies on endophytic bacteria of plants. Canadian Journal of Microbiology, v.43, p.411-416, 1997a.

HALLMANN, J.; QUADT-HALLMAN, A.; MAHAFFEE, W.F.; KLOEPPER, J.W. Bacterial endophytes in agricultural crops. Canadian Journal of Microbiology, v.43, p.895-914, 1997b.

HANEY, R.L.; SENSEMAN, S.A.; KRUTZ, L.J.; HONS, F.M. Soil carbon and nitrogen mineralization as affected by atrazine and glyphosate. Biology and Fertility of Soils, v.35, p.35-40, 2002.

HEAD, I.M.; SAUNDERS, J.R.; PICKUP, R.W. Microbial evolution, diversity, and ecology: a decade of ribosomal RNA analysis of uncultivated microorganism. Microbial Ecology, v.35, p.1-21, 1998. 
HENCKEL, T.; FRIEDRICH, M.; CONRAD, R. Molecular analyses of the methane-oxidizing microbial community in rice field soil by targeting the genes of the 16S rRNA, particulate methane monooxygenase, and methanol dehydrogenase. Applied and Environmental Microbiology, v.66, p.19801990, 1999.

HEUER, H.; SMALLA, K. Application of denaturing gradient gel electrophoresis and temperature gradient gel electrophoresis for studying soil microbial communities. In: VAN ELSAS, J.D.; TREVORS, J.T.; WELLINGTON, E.M.H (Ed.) Modern Soil Microbiology. New York: Marcel Dekker, 1997, cap.12b, p.353-373.

HEUER, H.; SMALLA, K. Bacterial phyllosphere communities of Solanum tuberosum L. and T4-lysozyme-producing transgenic variants. FEMS Microbiology Ecology, v.28, p.357-371, 1999.

HEYNDRICKX, M.; VAUTERIN, L.; VANDAMME, P.; KERSTERS, K.; DE VOS, P. Applicability of combined amplified ribosomal DNA restriction analysis (ARDRA) patterns in bacterial phylogeny and taxonomy. Journal of Microbiological Methods, v.26, p.247-259, 1996.

HIRANO, S.S.; HUPPER, C.D. Bacteria in the leaf ecosystem with emphasis on Pseudomonas syringae - a pathogen, ice nucleus, and epiphyte. Microbiology and Molecular Biology Reviews, v.64, p.624-653, 2000.

HOLLAND, M.A. Occam's razor applied to hormology: Are cytokinins produced by plants? Plant Physiology, v.115, p.865-868, 1997.

HOLLAND, M.A.; POLACCO, J.C. PPFMs and other covert contaminants: is there more to plant physiology than just plant? Annual Review of Plant Physiology and Plant Molecular Biology, v.45, p.197-209, 1994. 
HUGENHOLTZ, P.; PACE, N.R. Identifying microbial diversity in the natural environment: a molecular phylogenetic approach. Trends in Biotechnology, v.14, p.190-197, 1996.

HUGENHOLTZ, P.; GOEBEL, B.M.; PACE, N.R. Impact of culture independent studies on the emerging phylogenetic view of bacterial diversity. Journal of Bacteriology, v.180, p.4765-4774, 1998.

HUNTER-CEVERA, J.C. The value of microbial diversity. Current Opinion in Microbiology, v.1, p.278-285, 1998.

JACQUES, M.A.; MORRIS, C.E. A review of issues related to the quantification of bacteria from the phyllosphere. FEMS Microbiology Ecology, v.18, p.114, 1995.

JAIN, D.K.; PATRIQUIN, D.G. Characterization of a substance produced by Azospirillum which causes branching of wheat root hairs. Canadian Journal of Microbiology, v.31, p.206-210, 1985.

JAMES, E.K. Nitrogen fixation in endophytic and associative symbiosis. Field Crops Research, v.65, p.197-209, 2000.

JAMES, E.K.; OLIVARES, F.L. Infection and colonization of sugar cane and other graminaceous plants by endophytic diazotrophs. Critical Reviews in Plant Sciences, v.17, p.77-119, 1997.

JAMES, E.K.; REIS, V.M.; OLIVARES, F.L.; BALDANI, J.I.; DOBEREINER, J. Infection of sugar cane by the nitrogen-fixing bacterium Acetobacter diazotrophicus. Journal of Experimental Botany, v.45, p.757-766, 1994.

JENSEN, E.S.; HAUGGAARD-NIELSEN, H. How can increased use of biological $\mathrm{N}_{2}$ fixation in agriculture benefit the environment? Plant and Soil, v.252, p.177-186, 2003. 
JIMENEZ-SALGADO, T.; FUENTES-RAMIREZ, L.E.; TAPIA-HERNANDEZ, A.; MASCARUA-ESPARZA, M.A.; MARTINEZ-ROMERO, E.; CABALLEROMELLADO, J. Coffea arábica L., a new host plant for Acetobacter diazotrophicus, and isolation of other nitrogen-fixing acetobacteria. Applied and Environmental Microbiology, v.63, p.3676-3683, 1997.

KATIYAR, V.; GOEL, R. Solubilization of inorganic phosphate and plant growth promotion by cold tolerant mutants of Pseudomonas fluorescens. Microbiology Research, v.158, p.163-168, 2003.

KINKEL, L.L.; WILSON, M.; LINDOW, S.E. Plant species and plant incubation conditions influence variability in epiphytic bacterial population size. Microbial Ecology, v.39, p.1-11, 2000.

KITAJIMA, E.W.; LEITE, B. Curso introdutório de microscopia eletrônica de varredura. 2.ed. Piracicaba, NAP/MEPA - ESALQ/USP, 1999. 46p.

KLOEPPER, J.W.; RODRÍGUEZ-KÁBANA, R.; McINROY, J.A.; COLLINS, D.J. Analysis of populations and physiological characterization of microorganisms in rhizospheres of plants with antagonistic properties to phytopathogenic nematodes. Plant and Soil, v.136, p.95-102, 1991.

KOENIG, R.L.; MORRIS, R.O.; POLACCO, J.C. tRNA is the source of low-level trans-zeatin production in Methylobacterium spp. Applied and Environmental Microbiology, v.184, p.1832-1842, 2002.

KRZYSKO-LUPICKA, T.; ORLIK, A. The use of glyphosate as the sole source of phosphorus or carbon for the selection of soil-borne fungal strains capable to degrade this herbicide. Chemosphere, v.34, p.2601-2605, 1997. 
KUMAR, V.; NARULA, N. Solubilization of inorganic phosphates and growth emergence of wheat as affected by Azotobacter chroococcum mutants. Biology and Fertility of Soils, v.28, p.301-305, 1999.

LAMB, T.G.; TONKYN, D.W.; KLUEPFEL, D.A. Movement of Pseudomoas aureofaciens from the rhizosphere to aerial plant tissue. Canadian Journal of Microbiology, v.42, p.1112-1120, 1996.

LAMBRECHT, M.; OKON, Y.; BROEK, A.V.; VANDERLEYDEN, J. Indole-3acetic acid: a reciprocal signaling molecule in bacteria-plant interactions. Trends in Microbiology, v.8, p.298-300, 2000.

LAMPEL, J.S.; CANTER, G.L.; DIMOCK, M.B.; KELLY, J.L.; ANDERSON, J.J.; URATANI, B.B.; FOULKE-JR, J.S.; TURNER, J.T. Integrative cloning, expression, and stability of the $\operatorname{cry} I A(c)$ gene from Bacillus thurigiensis subsp. kurstaki in a recombinant strain of Clavibacter xyli subsp. cynodontis. Applied and Environmental Microbiology, v.60, p.501-508, 1994.

LEVESQUE, C.A.; RAHE, J.E. Herbicide interactions with fungal root pathogens, with special reference to glyphosate. Annual Reviews Phytopathology, v.30, p.597-602, 1992.

LINDOW, S.E.; ANDERSEN, G.L. Influence of immigration on epiphytic bacteria populations on navel orange leaves. Applied and Environmental Microbiology, v.62, p. 2978-2987, 1996.

LODEWYCKX, C.; VANGRONSVELD, J.; PORTEOUS, F.; MOORE, E.R.B.; TAGHAVI, S.; MEZGEAY, M.; VAN DER LELIE, D. Endophytic bacteria and their potential applications. Critical Reviews in Plant Sciences, v.21, p.583606, 2002. 
LOUWS, F.J.; RADEMAKER, J.L. W.; BRUIJN, F.J. The three of PCR-based genomic analysis of phytobacteria: Diversity, detection and disease diagnosis. Annual Reviews Phytopathology, v.37, p.81-125, 1999.

LUCANGELI, C.; BOTTINI, R. Effects of Azospirillum spp. on endogenous gibberellin content and growth of maize (Zea mays L.) treated with uniconazole. Symbiosis, v.23, p.63-72, 1997.

MANULIS, S.; HAVIV-CHESNER, A.; BRANDL, M.T.; LINDOW, S.E.; BARASH, I. Differential involvement of indole-3-acetic acid biosynthetic pathways in pathogenicity and epiphytic fitness of Erwinia herbicola pv. gypsophilae. Molecular Plant-Microbe Interactions, v.7, p.634-642, 1998.

MARCON, J. Isolamento e caracterização genética de actinomicetos endofíticos de Citrus spp. e interação com Xylella fastidiosa. São Paulo, 2002. 91p. Dissertação (Mestrado) - Universidade de São Paulo.

MARILLEY, L.; ARAGNO, M. Phylogenetic diversity of bacterial communities differing in degree of proximity of Lolium perenne and Trifolium repens roots. Applied Soil Ecology, v.13, p.127-136, 1999.

MAY, R.; VOLKSCH, B.; KAMPMANN, G. Antagonistic of epiphytic bacteria from soybean leaves against Pseudomonas syringae pv. glycinea in vitro and in plant. Microbial Ecology, v.34, p.118-124, 1997.

McCULLY, M.E. Niches for bacterial endophytes in crop plants: a plant biologist's view. Australian Journal of Plant Physiology, v.28, p.983-990, 2001.

McGRATH, J.W.; HAMMERSCHMIDT, F.; QUINN, J.P. Biodegradation of phosphonomycin by Rhizobium huakuii PMY1. Applied and Environmental Microbiology, v.64, p.356-358, 1998. 
McINROY, J.A.; KLOEPPER, J.W. Population dynamics of endophytic bacteria in field-grown sweet corn and cotton. Canadian Journal of Microbiology, v.41, p.895-901, 1995a.

McINROY, J.A.; KLOEPPER, J.W Survey of indigenous bacterial endophytes from cotton and sweet corn. Plant and Soil, v.173, p.337-342, 1995b.

MISAGHI, I.J.; DONNDELINGER, C.R. Endophytic bacteria in symptom-free cotton plants. Phytopathology, v.80, p.808-811, 1990.

MOCALI, S.; BERTELLI, E.; CELLI, F.D.; MENGONI, A.; SFALANGA, A.; VILANI, F.; CACIOTTI, A.; TEGLI, S.; SURICO, G.; FANI, R. Fluctuation of bacteria isolated from elm tissues during different seasons and from different plant organs. Research in Microbiology, v.154, p.105-114, 2003.

MURASHIGUE, T.; SKOOG, F. A revised medium for rapid grown and bioassays with tobacco tissue culture. Physiologia Plantarum, v.15, p.473497, 1962.

MURRAY, F.R.; LATCH, G.C.M.; SCOTT, D.B. Surrogate transformation of perennial ryegrass, Lollium perenne, using genetically modified Acremonium endophyte. Molecular General Genetics, v.23, p.1-9, 1992.

MUYZER, G.; DE WAAL, E.C.; UITTERLINDEN, A. Profiling of complex microbial populations using denaturing gradient gel electrophoresis analysis of polymerase chain reaction-amplified genes encoding for 16S rRNA. Applied and Environmental Microbiology, v.59, p.695-700, 1993.

MUYZER, G.; SMALLA, k. Application of denaturing gradient gel electrophoresis (DGGE) and temperature gradient gel electrophoresis (TGGE) in microbial ecology. Antonie van Leeuwenhoek, v.73, p.127-141, 1998. 
MYERS, N. Environmental services of biodiversity. Proceedings of the National Academy of Sciences, v.93, p.2764-2769, 1996.

NAMBIAR, P. T. C.; MA, S. W.; IYER, V. N. Limiting an insect infestation of nitrogen-fixing root nodules of the Pigeon pea (Cajanus cajan) by engineering the expression of an entomocidal gene in its root nodules. Applied and Environmental Microbiology, v.56, p.2866-2869, 1990.

NAUTIYAL, C.S. An efficient microbiological growth medium for screening phosphate solubilizing microorganisms. FEMS Microbiology Letters, v.170, p.265-270, 1999.

NEUMAIER, N.; NEPOMUCENO, A.L.; FARIAS, J.R.B.; OYA, T. Estádios de desenvolvimento da cultura de soja. In: BONATO, E.R. (Ed.) Estresses em Soja. Passo Fundo: EMBRAPA-Trigo, 2000. cap.1, p.21-44.

NEVES, M.C.P.; RUMJANEK, N.G. Ecologia das bactérias diazotróficas nos solos tropicais. In: MELO, I.S.; AZEVEDO, J.L. (Ed.) Ecologia Microbiana. Jaguariúna: EMBRAPA-Meio Ambiente, 1998. cap.1 , p.15-60.

NICHOLSON, P.S.; HIRSCH, P.R. The effects of pesticides on the diversity of culturable soil bacteria. Journal of Applied Microbiology, v.84, p.551-558, 1998.

NOGUEIRA, N.L.; BARROSO, P.A.V. Microscopia eletrônica aplicada aos estudos de ecologia microbiana. In: MELO, I.S.; AZEVEDO, J.L. (Ed.), Ecologia Microbiana. Jaguariúna: EMBRAPA-Meio Ambiente, 1998. cap.11, p.279-307.

O'BRIEN, R.D.; LINDOW, S.E. Effect of plant species and environmental conditions on epiphytic populations sizes of Pseudomonas syringae and other bacteria. Phytophatology, v.79, p.619-627, 1989. 
OBOJSKA, A.; LEJCZAK, B.; KUBRAK, M. Degradation of phosphonates by streptomycete isolates. Applied Microbiology and Biotechnology, v.51, p.872-876, 1999.

OEHRLE, N.W.; KARR, D.B.; KREMER, R.J.; EMERICH, D.W. Enhanced attachment of Bradyrhizobium japonicum to soybean through reduced root colonization of internally seedborne microorganisms. Canadian Journal of Microbiology, v.46, p.600-606, 2000.

OLIVEIRA, I.A.; VASCONCELLOS, M.J.; SELDIN, L.; PAIVA, E.; VARGAS, M.A.; SÁ, N.M.H. Random amplified polymorphic DNA analysis of effective Rhizobium sp. associated with beans cultivated in Brazilian cerrado soils. Brazilian Journal of Microbiology, v.31, p.39-44, 2000.

OVREAS, L.; TORSVIK, V. Microbial diversity and community structure in two different agricultural soil communities. Microbial Ecology, v.36, p.303-315, 1998.

PACE, N.R. A molecular view of microbial diversity and the biosphere. Science, v.276, p.734-740, 1997.

PALUS, J.A.; BORNEMAN, J.; LUDDEN, P.W.; TRIPLETT, E.W. A diazotrophic bacterial endophyte isolated from stems of Zea mays $L$. and Zea luxurians Iltis and Doebley. Plant and Soil, v.186, p.135-142, 1996.

PAN, M.J.; RADEMAN, S.; KUNERT, K.; HASTINGS, J.W. Ultrastructural studies on the colonization of banana tissue and Fusarium oxysporium f. sp. cubense race 4 by endophytic bacterium Burkholderia cepacia. Journal of Phytopathology, v.145, p.479-486, 1997. 
PARALES, R.E.; DITTY, J.L.; HARWOOD, C.S. Toluene-Degrading Bacteria Are Chemotactic towards the Environmental Pollutants Benzene, Toluene, and Trichloroethylene. Applied and Environmental Microbiology, v.66, p.4098-4104, 2000.

PATTEN, C.L.; GLICK, B.R. Bacterial biosynthesis of indole-3-acetic acid. Canadian Journal of Microbiology, v.42, p.207-220, 1996.

PATTEN, C.L.; GLICK, B.R. Role of Pseudomonas putida indoleacetic acid in development of the host plant root system. Applied and Environmental Microbiology, v.68, p.3795-3801, 2002.

PEIXOTO NetO, P.A.S.; AZEVEDO, J.L.; ARAÚJO, W.L. Microrganismos endofíticos: interação com plantas e potencial biotecnológico. Biotecnologia Ciência e Desenvolvimento, v.29, p.62-76, 2002.

PENALOZA-VAZQUEZ, A.; MENA, G.L.; HERRERA-ESTRELLA, L.; BAILEY, A.M. Cloning and sequencing of the genes involved in glyphosate utilization by Pseudomonas pseudomallei. Applied and Environmental Microbiology, v.61, p.538-543, 1995.

PETRINI, O. Fungal endophyte of tree leaves. In: ANDREWS, J.H.; HIRANO, S.S. (Ed.) Microbial Ecology of Leaves. New York: Spring Verlag, 1991. cap. 9, p.179-197.

PILLAY, V.K.; NOWAK, J. Inoculum density, temperature, and genotype effects on in vitro growth promotion and epiphytic and endophytic colonization of tomato (Lycopersicon esculentum L. ) seedlings inoculated with a pseudomonad bacterium. Canadian Journal of Microbiology, v.43, p.354361, 1997. 
POLONENKO, D.R.; SCHER, F.M.; KLOEPPER, J.W.; SINGLETON, C.A.; LALIBERTE, M.; ZALESKA, I. Effects of root colonizing bacteria on nodulation of soybean roots by Bradyrhizobium japonicum. Canadian Journal of Microbiology, v.33, p.498-503, 1987.

PRESTIDGE, R.A.; SPROSEN, J.M. The effect of glyphosate, paraquat and paclobutrazol on lolitrem $B$ levels in endophyte-infected perennial ryegrass. New Zealand Veterinary Journal, v.43, p.138-140, 1995.

PRINSEN, E.; COSTACURTA, A.; MICHIELS, K.; VANDERLEYDEN, J.; VAN ONCKELEN, H. Azospirillum brasiliensei indole-3-acetic acid biosynthesis: evidence for a non-tryptophan dependent pathway. Molecular PlantMicrobe Interactions, v.6, p.609-615, 1993.

QUADT-HALLMANN, A.; BENHAMOU, N.; KLOEPPER, J.W. Bacterial endophytes in cotton: mechanisms of entering the plant. Canadian Journal of Microbiology, v.43, p.577-582, 1997a.

QUADT-HALLMANN, A.; HALLMANN, J.; KLOEPPER, J.W. Bacterial endophytes in cotton: location and interaction with other plant-associated bacteria. Canadian Journal of Microbiology, v.43, p.254-259, 1997b.

QUISPEL, A. Bacteria-plant interactions in symbiotic nitrogen fixation. Physiologia Plantarum, v.74, p.783-790, 1988.

RAMAMOORTHY, V.; VIWANATHAN, R.; RAGUCHANDER, T.; PRAKASAM, V.; SAMIYAPPAN, R. Induction of systemic resistance by plant growth promoting rhizobacteria in crop plants against pests and diseases. Crop Protection, v.20, p.1-11, 2001. 
RANJARD, L.; POLY, F.; NAZARET, S. Monitoring complex bacterial communities using culture-independent molecular techniques: application to soil environment. Research in Microbiology, v.151, p.167-177, 2000.

RAVEN, P.H.; EVERT, R.F.; EICHHORN, S.E. Regulando o crescimento e o desenvolvimento: os hormônios vegetais. In: RAVEN, P.H.; EVERT, R.F.; EICHHORN, S.E. (Ed.) Biologia Vegetal. Rio de Janeiro: Guanabara Koogan, 2001. cap.28, p.646-675.

REINHOLD-HUREK, B.; HUREK, T. Interactions of gramineous plants with Azoarcus spp. And other diazotrophs: identification, localization, and perspectives to study their function. Critical Reviews in Plant Sciences, v.17, p.29-54, 1998.

REIS, V.M.; BALDANI, J.I.; BALDANI, V.L.D.; DOBEREINER, J. Biological dinitrogen fixation in gramineae and plam trees. Critical Reviews in Plant Science, v.19, p.227-247, 2000.

REIS-JR, F.B.; REIS, V.M.; URQUIAGA, S.; DOBEREINER, J. Influence of nitrogen fertilization on the population of diazotrophic bacteria Herbaspirillum spp. And Acetobacter diazotrophicus in sugar cane (Saccharum spp.). Plant and Soil, v.219, p.153-159, 2000.

REITER, B.; PFEIFER, U.; SCHWAB, H.; SESSITSCH, A. Response of endophytic bacterial communities in potato plants to infection with Erwinia carotovora sbsp. atrosptica. Applied and Environmental Microbiology, v.68, p.2261-2268, 2002.

RICHARDSON, J.; STEAD, D.E.; ELPHINSTONE, J.G.; COUTTS, R.H.A. Diversity of Burkholdeeria isolates from woodland rhizosphere environments. Journal of Applied Microbiology, v.93, p.616-630, 2002. 
RODRIGUEZ, H.; FRAGA, R. Phosphate solubilizing bacteria and their role in plant growth promotion. Biotechnology Advances, v.17, p.319-339, 1999.

RODRIGUEZ, H.; GONZALEZ, T.; SELMAN, G. Expression of a mineral phosphate solubilizing gene from Erwinia herbicola in two rhizobacterial strains. Journal of Biotechnology, v.84, p.155-161, 2000.

ROMEIRO, R.S. Bactérias Fitopatogênicas. 1.ed. Viçosa: UFV, 2000. p.283.

RUKAYADI, Y.; SUWANTO, A.; TJAHJONO, B.; HARLING, R. Survival and epiphytic fitness of a nonpathogenic mutant of Xanthomonas campestris pv. glycines. Applied and Environmental Microbiology, v. 66, p.1183-1189, 2000.

RUPPEL, S.; HECHT-BUCHHOLZ, C.; REMUS, R.; ORTMANN, U.; SCHMELZER, R. Settlement of the diazotrophic, phytoeffective bacterial strain Pantoea agglomerans on and within winter wheat: an investigation using ELISA and transmission electron microscopy. Plant and Soil, v.145, p.261-273, 1992.

SABARATNAM, S.; BEATTIE, G. Differences between Pseudomonas syringae pv. syringae B728a and Pantoea agglomerans BRT98 in epiphytic and endophytic coloniztin of leaves. Applied and Environmental Microbiology, v.69, p.1220-1228, 2003.

SALDANÃ, G.; MARTINEZ-ALCÁNTARA, V.; VINARDELL, J.M.; BELLOGÍN, R.; RUÍZ-SAINZ, J.E.; BALATTI, P.A. Genetic diversity of fast-growing rhizobia that nodulate soybean (Glycine max L. Merr). Archives of Microbiology, v.180, p.45-52, 2003. 
SAMBROOK, J.; FRITSCH, E.F.; MANIATIS, T. Molecular cloning: A laboratory manual. 2.ed. New York: Cold Spring Harbor Laboratory Press, 1989.

SANTOS, A.; FLORES, M. Effects of glyphosate on nitrogen fixation of freeliving heterotrophic bacteria. Letters in Applied Microbiology, v.20, p.349352, 1995.

SARWAR, M.; KREMER, R.J. Determination of bacterially derived auxins using a microplate method. Letters in Applied Microbiology, v.20, p.282-285, 1995.

SESSITSCH, A.; REITER, B.; PFEIFER, U.; WILHELM, E. Cultivationindependent population analysis of bacterial endophytes in three potato varieties based on eubacterial and Actinomycetes-specific PCR of 16S rRNA genes. FEMS Microbiology Ecology, v.39, p.23-32, 2002.

SHIMOSAKA, M.; FUKUMORI, Y.; ZHANG, X.Y.; HE, N.J.; KODARIA, R.; OKAZAKI, M. Molecular cloning and characterization of a chitosanase from the chitosanolytic bacterium Burkholderia gladioli strain CHB101. Applied in Microbiology and Biotechnology, v.54, p.354-360, 2000.

SHISHIDO, M.; BREUIL, C.; CHANWAY, C.P. Endophytic colonization of spruce by growth-promoting rhizobacteria. FEMS Microbiology Ecology, v.29, p.191-196, 1999.

SICILIANO, S.D.; FORTIN, N.; MIHOC, A.; WISSE, G.; LABELLE, S.; BEAUMIER, D.; OUELLETTE, D.; ROY, R.; WHYTE, L.G.; BANKS, M.K.; SCHWAB, P.; LEE, K.; GREER, C.W. Selection of specific endophytic bacterial genotypes by plants in response to soil contamination. Applied in Environmental Microbiology, v.67, p.2469-2475, 2001. 
SINCLAIR, J.B. Latent infection of soybean plants and seeds by fungi. Plant Disease, v.75, p.220-224, 1991.

STEEL, R.G.D.; TORRIE, J.H. Principles and procedures of statistics: a biometrical approach. Toronto: McGraw-Hill, 1980. p.633.

STOLTZFUS, J.R.; SO, R.; MALARVITHI, P.P.; LADHA, J.K.; BRUIJN, F.J. Isolation of endophytic bacteria from rice and assessment of their potential for supplying rice with biologically fixed nitrogen. Plant and Soil, v.194, p.2536, 1997.

STURZ, A.V. The role of endophytic bacteria during seed piece decay and potato tuberization. Plant and Soil, v.175, p.257-263, 1995.

STURZ, A.V.; CHRISTIE, B.R.; MATHESON, B.G. Associations of bacterial endophyte populations from red clover and potato crops with potential for beneficial allelopathy. Canadian Journal of Microbiology, v.44, p.162-167, 1998.

STURZ, A.V.; CHRISTIE, B.R.; MATHESON, B.G.; NOWAK, J. Biodiversity of endophytic bacteria which colonize red clover nodules, roots, stems and foliage and their influence on host growth. Biological and Fertilizer Soils, v.25, p.13-19, 1997.

STURZ, A.V.; CHRISTIE, B.R.; NOWAK, J. Bacterial endophytes: potential role in developing sustainable systems of crop production. Critical Reviews in Plant Sciences, v.19, p.1-30, 2000.

STURZ, A.V.; MATHESON, B.G. Populations of endophytic bacteria which influence host-resistance to Erwinia-induced bacterial soft rot in potato tubers. Plant and Soil, v.184, p.265-271, 1996. 
SY, A.; GIRAUD, E.; JOURAND, P.; GARCIA, N.; WILLEMS, A.; LAJUDIE, P.; PRIN, Y.; NEYRA, M.; GILLIS, M.; BOIVIN-MASSON, C.; DREYFUS, B. Methylotrophic Methylobacterium bacteria nodulate and fix nitrogen in symbiosis with legumes. Journal of Bacteriology, v.183, p.214-220, 2001.

TERNAN, N.G.; McGRATH, J.W.; QUINN, J.P. Phosphoenolpyruvate phosphomutase activity in an L-phosphonoalanine-mineralizing strain of Burkholderia cepacia. Applied and Environmental Microbiology, v.64, p.2291-2294, 1998.

THIRUP, L.; JOHNSEN, K.; WINDING, A. Succession of Indigenous Pseudomonas spp. and Actinomycetes on Barley Roots Affected by the Antagonistic Strain Pseudomonas fluorescens DR54 and the Fungicide Imazalil. Applied and Environmental Microbiology, v.67, p.1147-1153, 2001.

TOMASINO, S.F.; LEISTER, R.T.; DIMOCK, M.B.; BEACH, R.M.; KELLY, J.L. Field performance of Clavibacter xyli subsp. cynodontis expressing the insecticidal protein gene $\operatorname{cryIA}(c)$ of Bacillus thurigiensis against European corn borer in field corn. Biological Control, v.5, p.442-448, 1995.

UEDA, T.; SUGA, Y.; YAHIRO, N.; MATSUGUCHI, T. Remarkable $\mathrm{N}_{2}$-fixing bacterial diversity detected in rice roots by molecular evolutionary analysis of nifH gene sequences. Journal of Bacteriology, v.177, p.1414-1417, 1995.

ULLRICH, M.S.; SCHERGAUT, M.; BOCH, J.; ULLRICH, B. Temperatureresponsive genetic loci in the plant pathogen Pseudomonas syringae pv. glycinea. Microbiology, v.146, p.2457-2468, 2000. 
VAN ELSAS, J.D.; DUARTE, G.F.; ROSADO, A.S.; SMALLA, K. Microbiological and molecular biological methods for monitoring microbial inoculants and their effects in the soil environmental. Journal of Microbiological Methods, v.32, p.133-154, 1998.

VAN LOON, L.C.; BAKKER, P.A.H.M.; PIETERSE, C.M. Systemic resistance induced by rhizosphere bacteria. Annual Reviews in Phytopathology, v.36, p.453-483, 1998.

VASSILEV, N; VASSILEVA, M. Biotechnological solubilization of rock phosphate on media containing agro-industrial wastes. Applied Microbiology and Biotechnology, v.61, p.435-440, 2003.

VAZQUEZ, P.; HOLGUIN, G.; PUENTE, M.E.; LOPEZ-CORTES, A.; BASHAN, $Y$. Phosphate-solubilizing microorganisms associated with the rhizosphere of mangroves in a semiarid coastal lagoon. Biology and Fertility of Soils, v.30, p.460-468, 2000.

VERMA, S.C.; LADHA, J.K.; TRIPATHI, A.K. Evaluation of plant growth promoting and colonization ability of endophytic diazotrophs from deep water rice. Journal of Biotechnology, v.91, p.127-141, 2001.

VOLKSCH, B.; ULLRICH, M.; FRITSCHE, W. Identification and population dynamics of bacteria in leaf spots of soybean. Microbial Ecology, v.24, p.305-311, 1992.

WELSH, J.; MCCLELLAND, M. Fingerprinting using PCR with arbitrary primers. Nucleic Acids Research, v.18, p.7213-7218, 1990. 
WHITESIDES, S.K.; SPOTTS, R.A. Frequency, distribution, and characteristics of endophytic Pseudomonas syringae in pear trees. Phytopathology, v.81, p.453-457, 1991.

WILLIAMS, J.G.K.; KUBELIK, A.R.; LIVAK, K.J.; RAFALSKI, J.A.; TINGEY, S.V. DNA polymorphisms amplified by arbitrary primers are useful as genetic markers. Nucleic Acids Research, v.18, p.6531-6535, 1990.

YANG, C.H.; CROWLEY, D.E. Rhizosphere microbial community structure in relation to root location and plant iron nutritional status. Applied and Environmental Microbiology, v.66, p.345-351, 2000.

YAP, I.; NELSON, R.J. Winboot: a program for performing bootstrap analysis of binary data to determine the confidence limits of UPGMA-based dendrograms. IRRI Discussion Paper Series, v.14, 1996.

ZEHR, J.P.; JENKINS, B.D.; SHORT, S.M.; STEWARD, G.F. Nitrogenase gene diversity and microbial community structure: a cross-system comparison. Environmental Microbiology, v.5, p.539-554, 2003.

ZINNIEL, D.K.; LAMBRECHT, P.; HARRIS, N.B.; FENG, Z.; KUCZMARSKI, D.; HIGLEY, P.; ISHIMARU, C.A.; ARUNAKUMARI, A.; BARLETTA, R.G.; VIDAVER, A.K. Isolation and characterization of endophytic colonizing bacteria from agronomic crops and prairie plants. Applied and Environmental Microbiology, v.68, p.2198-2208, 2002. 